\title{
REDD+ Governmentality:
}

\section{Governing Forest, Land, and Forest Peoples in \\ Indonesia}

By

Rini Yuni Astuti

A thesis submitted to the Victoria University of Wellington in fulfillment of the requirements for the degree of Doctor of Philosophy

Victoria University of Wellington

2016 


\begin{abstract}
Aimed at lowering forest carbon emissions through financing improved forest governance and socially inclusive land and natural resources use, the REDD+ (Reducing Emissions from Deforestation and Forest Degradation Plus) program is attracting widespread interest and investment in Indonesia. REDD+ introduces new governmental rationalities, in which forest carbon is used as a standard to measure a country's performance in keeping its tropical forests intact and defines the financial rewards the country will receive. REDD+ is one factor in an emergent new political conjuncture in Indonesia that is opening up to the possibilities for reworking forest governance. This thesis employs Foucault's concept of governmentality to examine how governmental technologies are formed, contested and implemented through REDD+ and some of the early impacts the program is having (Foucault, 1991a).
\end{abstract}

Drawing on grounded empirical data and inspired by a 'not-quite neoliberal nature' framework (de Freitas, Marston and Bakker, 2015) I show how place-based discourses, politics, actors, and interests are shaping the way REDD+ unfolds in Indonesia. This is achieved through three case studies focused on the REDD+ Taskforce; the One Map Initiative; and an Indigenous land claim in a community in Central Kalimantan. Findings from the three case studies show how current deficiencies in forestland governance have been problematized where there is no clarity over who has rights to forestland, who owns the concessions and where they are. Thus, addressing current complexities is becoming the Taskforce's priority through series of governmental technologies including the One Map Initiative. Meanwhile, activists are making use of this opportunity to render visible Indigenous land rights in an attempt to subvert focused technical fixes to more open social justice ends. By discussing the messy actualities of developing, implementing and responding to governmental technologies the thesis problematizes pro- and antiREDD+ debates.

Rather than view REDD+ governmental technologies through "a programmer's view" (Death, 2013) as a finished or rigid project implemented on others, I see it as 
an ongoing attempt to govern human - forest relationships that are shaped by contestations and resistances. Thus, the thesis makes an important contribution to neoliberal nature literature by showing that neoliberal governmental programs, such as REDD+, should be seen as sites of struggle, with different actors experiencing and engaging the program in different ways. As such, this thesis highlights how neoliberal mechanisms can be co-opted by particular actors in order to achieve diverse economic, social and environmental goals. Through engagement with governmental technologies the landscapes of forest politics change in both enabling and constraining ways.

Keywords: governmentality, REDD+, governmental technology, subjectivity, neoliberal nature, not-quite-neoliberal nature, the REDD+ Taskforce, the One Map Initiative, Indigenous land claims, Indonesia. 
This thesis is dedicated to all scholar activists whose passions, struggles, and emotional dedication seek to bring some light to the world in the face of despair and doom. 


\section{Acknowledgements}

This thesis is a collective work that couldn't possibly have beeen completed without the support of the following wonderful people.

This $\mathrm{PhD}$ has, for me, been a truly great journey as I was personally involved with the passionate struggles of the peoples and institutions that I met during the 14 months of fieldwork in Indonesia. To the Bahanei, an Indigenous community located in Central Kalimantan, I say thank you so much for allowing me to be part of your struggle for land and identity. Thank you to Pak Dagik and Pak Nindit who facilitated my stay and provided crucial information for my research. To Alfianus Rinting, my fellow activist in AMAN Central Kalimantan, who has been my gate keeper, I say thank you so much for supporting my fieldwork and later providing assistance with making digital maps. To fellow activists in the AMAN National Office who were so helpful in introducing me to AMAN's work and struggles: to Abdon Nababan, Yoga Plee, and Hengky Satrio, I say thank you. Also to all the other environmental and Indigenous activists in Central Kalimantan, Jakarta and beyond, who were so accommodating and friendly.

My fieldwork was greatly assisted by the opportunity given to me by the REDD+ Agency to be part of its team. Thank you to William Sabandar, Iwan Wibisono, Vitri Sekarsari, and Boyke Lakaseru, for allowing me to probe into your work by asking so many questions.

I am deeply grateful for having had a wonderful team of supervisors: Andrew McGregor, Sophie Bond and Bethany Haalboom. This team has made my PhD journey into a means for me to mature both professionally and mentally.

I am truly blessed to have had Andrew McGregor as my supervisor. He provided a path for me to nurture my ability to acquire new knowledge and gain confidence. He listened patiently to my troubles and persistently convinced me that I could be the scholar activist that I have always aspired to be. He opened up a lot of opportunities that have shaped my views and future career. Andrew, I cannot thank you enough 
for these opportunities, the support, time, wisdom and motivation that you have given me.

I would like to thank Sophie Bond, my secondary supervisor, whose wisdom, care and knowledge saved me from making mistakes in my academic work. She provided me with a role model as a female academic that I wish to emulate someday. Thank you Sophie.

To Bethany Haalboom, my co-secondary supervisor, I would like to say thank for for the time, insights and knowledge that she provided me with during the course of the last year of my PhD. Thank you Bethany.

This PhD has been the adventure of a life time. It would not have been so much fun without the company of Pete Howson and Rowan Dixon. They involved me in countless witty philosophical conversations that kept me from getting bored. They have been good colleagues and friends; I am sure that this is not the only adventure that we will have together.

I would like to thank all the wonderful and brilliant academics and researchers who are involved in the Political Ecology of REDD+ project and which my $\mathrm{PhD}$ forms part of. The project provided the scholarship through the Marsden Fund that enabled this $\mathrm{PhD}$ to happen. Most importantly, this project facilitated my engagements with great scholars from all around the world; one of these was the $5^{\text {th }}$ Antipode Institute for the Geographies of Justice. To Sara Kindon, I say thank you so much for being so caring and thoughtful. You are the kind of feminist academic that is so inspirational and empathetic. Also, I give my thanks to Edward Challies, Sean Weaver, Mike Gavin, Suraya Affif, Mia Siscawati, Semiarto Aji Purwanto, and Luca Tacconi for all your absorbing discussions during the project workshops and paper writing process. I have been so lucky to be part of this project; I don't want it to end.

The School of Geography, Environment and Earth Science at Victoria University provided the supportive environment that I needed in order to thrive as a $\mathrm{PhD}$ student. I would like to thank all the inspirational lecturers that have helped me in 
many ways: Marcela Palomino Schalscha for giving advice on my proposal and to Head of School; Rewi Newnham for granting flexibility for me to work away from Victoria. Thanks also to the department administrators, especially to Monika Hanson, Allan Ball, and Miranda Voke who provided a great deal of assistance during my PhD candidacy.

I give my thanks to the group of bright students at Victoria with whom I shared warm friendships during the first year of my PhD: Anna Vesta Rogers, Amanda Thomas, Catherine Jones, Pao Cevallos, Gradon Diprose, Jana Borchers, Lorena de la Tore, Monique Beyer, Angelique Faramus, Santhia Selvarajah, Vaishna Santhar, and Pakjira Leelertphan

My stay in Wellington has been a wonderful time thanks to my Indonesian friends whose friendship has provided me with a home away from home. Thank you so much to Fenty Siregar, Anik Utomo, Marko Sebira, Farida Ariyani, Dwi Purwestri, and Setyo Utomo.

I owe a great debt for the support of the Department of Geography and Planning at Macquarie University which hosted the third year of my PhD. I would like to thank the Political Ecology group members Fiona Miller, Donna Houston, Sunita Chaudhary and Ashraful Alam for providing lively and fun discussions throughout my stay. I would also like to thank Richie Howitt for his wisdom, care and great knowledge which helped ease me through the difficult third year of my PhD.

To my thesis buddy Minna Hsu for her companionship and endless deep and critical conversations about life and love. Thanks also to the Department's great Postgraduate students: Rabiul Islam, Nicole McNamara, Laura Hammersmith, Marnie Graham, Claire Colyer, Lang Wang, Liqin Wu, and Dean Howard. To Sophie Maalsen, my office mate, I say thank you for all the chocolate supplies and support.

I am incredibly lucky to have had wonderful Indonesian friends in Sydney who provided shelter and companion during all the ups and downs of my $\mathrm{PhD}$ process: 
Bernardia Linggar Yekti, Ade Prastyani, Robertus Aji Nugroho, and Dewi Widyastuti. Thank you so much guys.

I couldn't have survived this PhD without the support of my wonderful friends back home in Indonesia. Thank you to my always encouraging thesis buddies Panca Pramudya and Yuti Ariani who lent me their support despite having challenging PhD journeys of their own.

To Yando Zakariya, Noer Fauzi Rachman and Yanuar Nugroho, three Indonesian scholars who have provided suggestions, comments, and supports, I say thank you. Their extensive knowledge and networks have provided helpful sanctuaries for my study and beyond.

I would also like to thank Tania Murray Li for her generosity in commenting on my papers and providing me with a significant boost in helping me to believe in my capacity to be a good researcher.

Thank you to Adrian Coen, my colleague who provided significant assistance by sorting through my grammatical errors. Thanks Adrian.

To my best friends in Indonesia who have been so very encouraging and provided virtual hugs and motivation: Munawarroh, Devi Suryani, Indra Soeharto, Annaliza Chaniago, Tetty Lubis, and Leony Aurora. Thank you all so much.

And finally, to my wonderful parents, I say thank you so much for believing that I would be able to reach the end of this PhD journey. To my mother, Atmi Indarti, a caring woman whom I love so much, thank you for your constant prayers that have kept me from illness and despair. To my Father, Bambang Slamet Raharjo, a supportive man whom I adore so much for being the most kind, fun and gentle father a daughter could ever wish to have. To my brother, Marhaendra Gunawan, I say thank you for being a supportive little brother and for taking care of our parents while I was away for this PhD. I have been so lucky to be surrounded by these wonderful people. 


\section{Table of Contents}

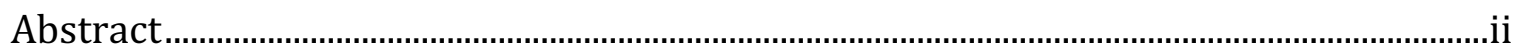

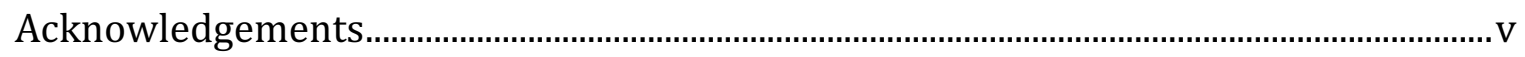

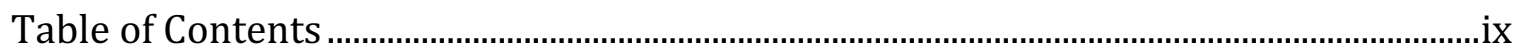

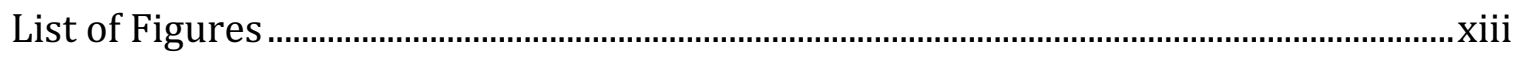

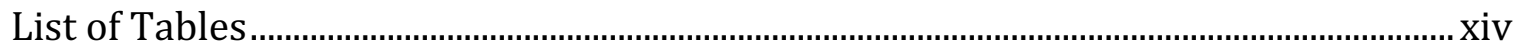

List of Abbreviations and Acronyms …………................................................................. XV

\section{Introduction REDD+ at the Intersection of Neoliberal and Not-Quite-}

Neoliberal Natures ...................................................................................................... 1

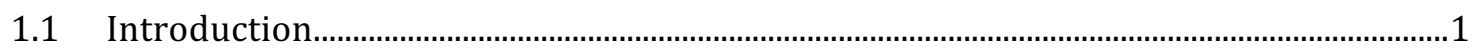

1.2 Situating REDD+ in Indonesia.............................................................................................

1.3 REDD+ and the Neoliberalization of Nature

1.4 REDD+ and Not-Quite-Neoliberal Nature ...........................................................................13

1.5 Research Objectives and Questions ……………................................................................17

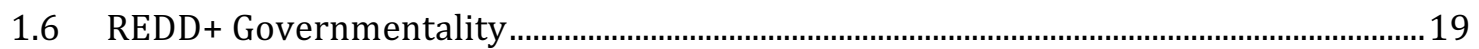

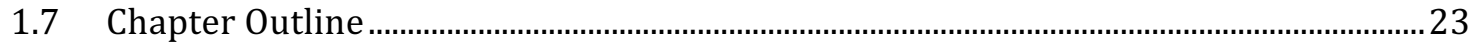

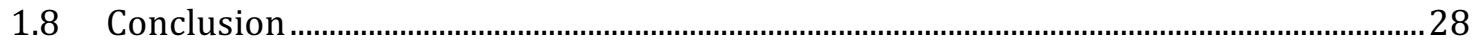

\section{Theoretical Review The Art of Governing Human and Forest}

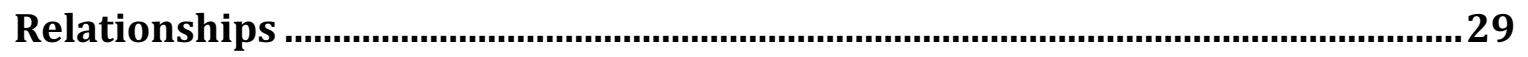

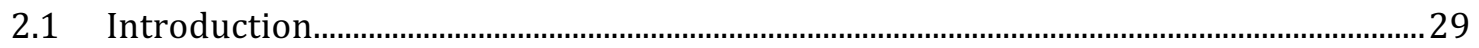

2.2 Three types of power: Sovereignty, Disciplinary and Biopower ........................................ 31

2.2.1 Sovereign Power ............................................................................................................ 32

2.2.2 Disciplinary Power.................................................................................................................. 33

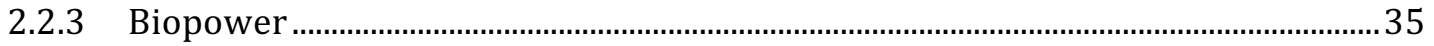

2.2.4 Summarising Power ……………………......................................................................37

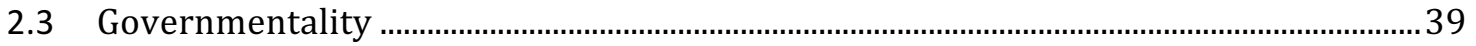

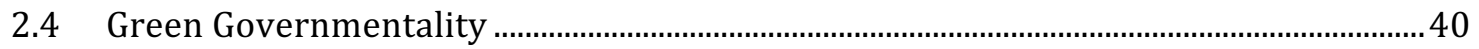

2.5 Neoliberal governmentality and the formation of new subjectivities ...........................43

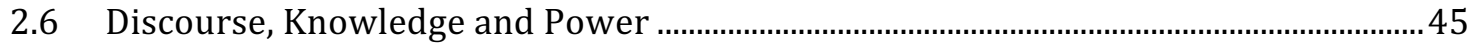

2.7 Analyzing REDD+ Governmentality .................................................................................... 47

2.8 Critiques and Limits of Governmentality......................................................................... 54

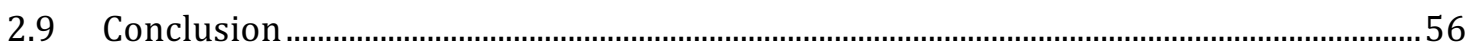




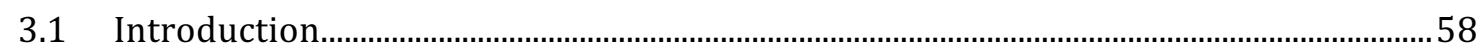

3.2 A Slippery Attempt to Undertake Critical yet Hopeful Geographical Research ...........58

3.3 Multi-sited and Multi-Scalar Critical Inquiry: Following "Beyond Carbon, More than Forest"

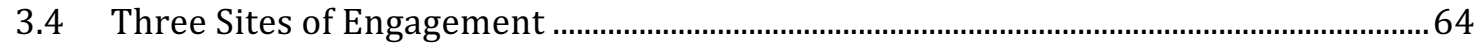

3.4.1 Case Study 1: The REDD+ Taskforce ……………………………………………......66

3.4.2 Case Study 2: The One Map Initiative ………………………………………………....67

3.4.3 Case Study 3: The Indigenous Land Claim Assemblage in Bahanei .........................68

3.5 Discussion on Data Collection Methods …………..............................................................69

3.5.1 Semi Structured Interviews ………………....................................................................69

3.5.2 Observation ............................................................................................................

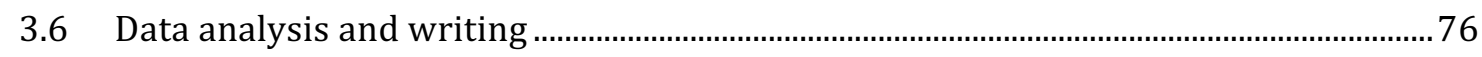

3.7 Positionality and Reflection: Being an Engaged Scholar Activist by Practising the

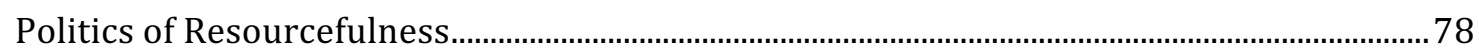

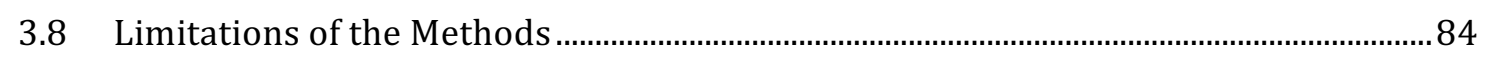

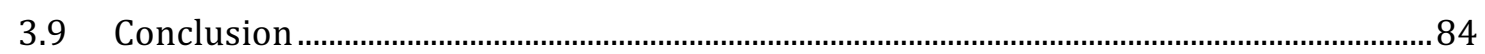

\section{Context Forest Politics in Indonesia: Actors, Interests and Contestations} 86

4.1 Introduction

4.2 Post-independence and the New Order Era .......................................................................

4.2.1 The Making of the State Forests ............................................................................... 87

4.2.2 Governing Indigenous Peoples and Rights ………........................................................91

4.2.3 Environmental and Indigenous Activism ......................................................................94

4.3 Post-Soeharto Era and the Inception of REDD+ ...........................................................96

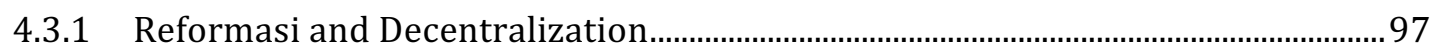

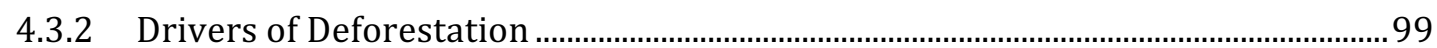

4.3.3 The Role of Social Movements in Reforming Forest Governance.......................... 101

4.3.4 REDD+ Inception............................................................................................................ 106

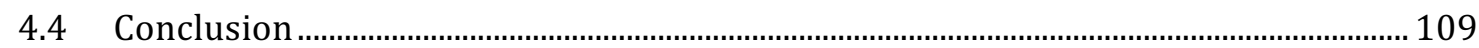

\section{Case Study One The REDD+ Taskforce: Governing Carbon and}

Transforming Forest Politics.................................................................................. 111

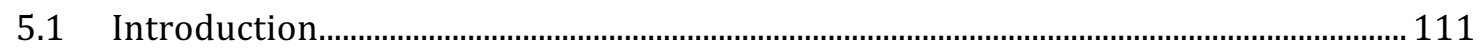

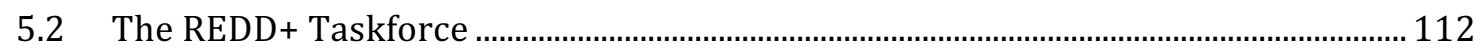

5.3 Normalising Carbon Rationalities ....................................................................................... 117 
5.3.1 Communicating Forest Carbon ............................................................................... 117

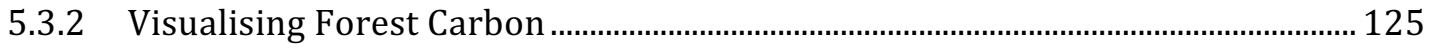

5.3.3 Engaging Forest Carbon....................................................................................... 131

$5.4 \quad$ Transforming Forest Politics? ……………................................................................... 135

5.5 The Short Life of the REDD+ Agency …………..................................................................... 137

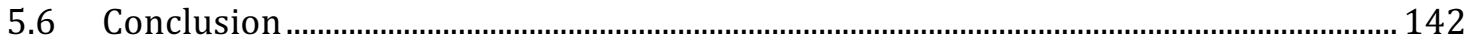

\section{Case Study Two The One Map Initiative: Producing "Governable Spaces"}

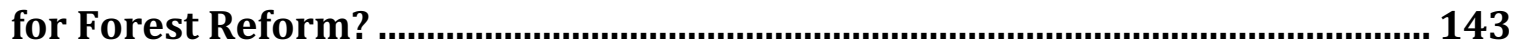

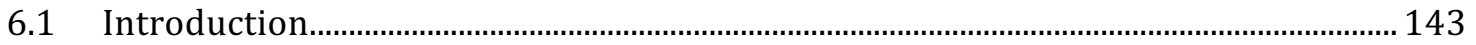

6.2 The Production of "Governable Spaces" for REDD+ Implementation ........................... 144

6.3 REDD+ and the Problematizing of Indonesia's Forest Governance .............................. 146

6.3.1 The Forest Moratorium as a Technology of Governance .......................................... 147

6.3.2 One Database as a Technology of Governance........................................................... 156

6.3.3 One Standard as a Technology of Governance …………………………………..... 160

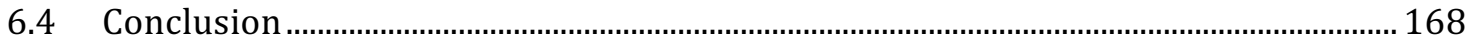

\section{Case Study Three Assembling Indigenous Land Claims within the New}

Political Conjuncture of Forest Governance in Indonesia ................................... 171

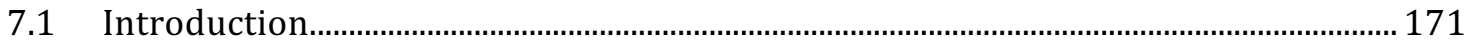

7.2 The New Forest Political Conjuncture and its Implications to Indigenous Land

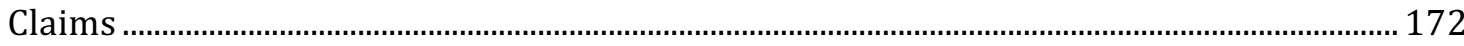

7.2.1 The Constitutional Court Decision No 35/2013 ……………………….................... 175

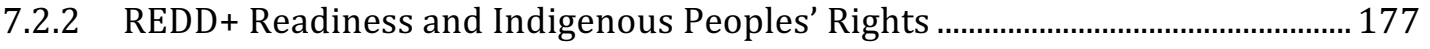

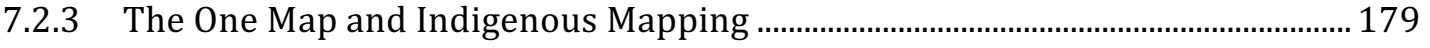

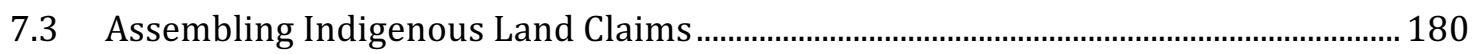

7.3.1 Producing Indigenous Territory ……………............................................................. 183

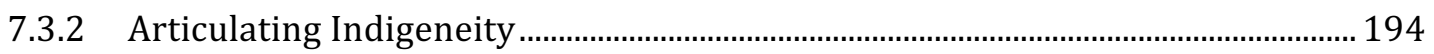

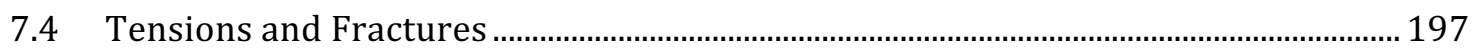

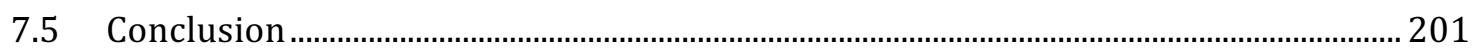

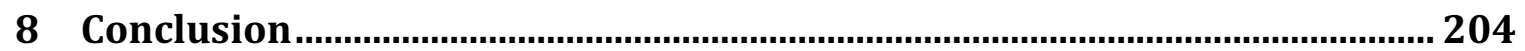

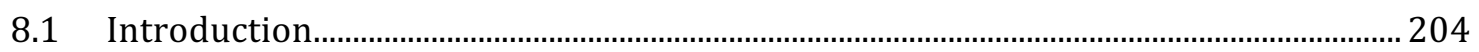

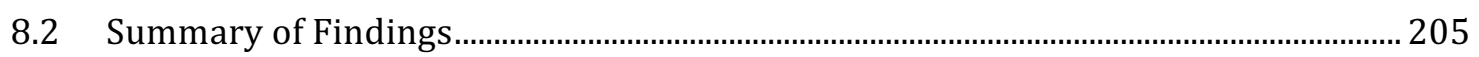

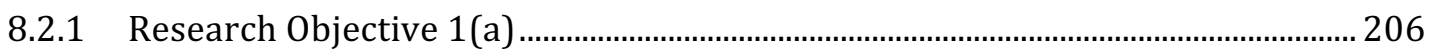

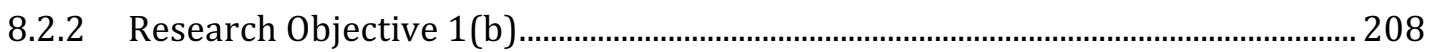

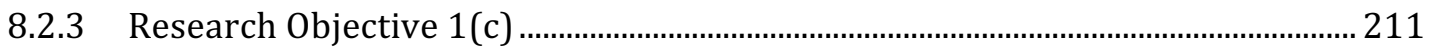

8.3 REDD+: Beyond Neoliberal Nature Rhetoric...................................................................... 213 
8.3.1 Flexibility and Ambiguity of REDD+.................................................................... 214

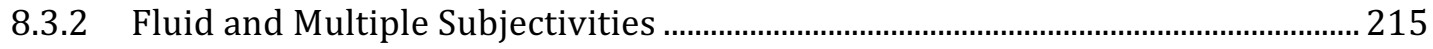

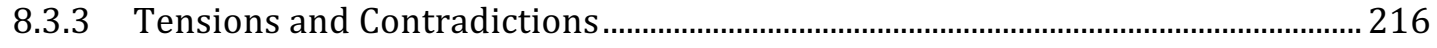

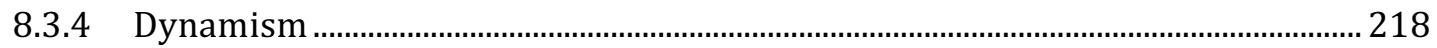

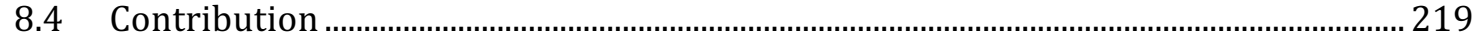

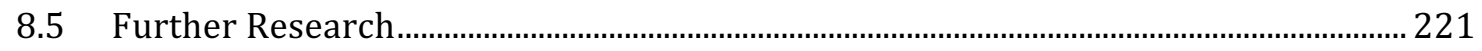

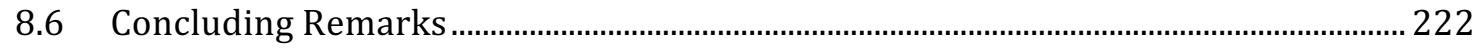

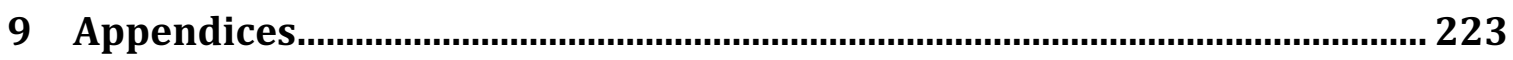

9.1 Appendix A: List of Indonesia's Government Ministries Related to REDD+ ............ 223

9.2 Appendix B: Human Ethics Approval ............................................................................... 225

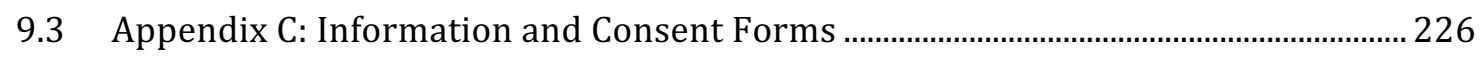

9.4 Appendix D: Transcriber Confidentiality Agreement....................................................... 228

9.5 Appendix E: JKPP’s Participative Mapping Procedures................................................... 229

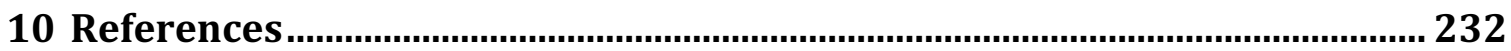




\section{List of Figures}

Figure 1.1 REDD+ transition in Indonesia ........................................................................

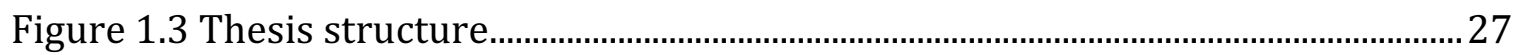

Figure 2.1 Theoretical framework of the research ............................................................. 54

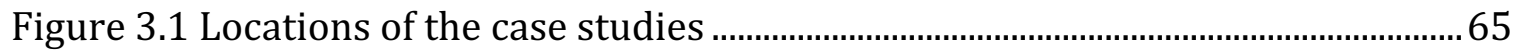

Figure 5.1 Images represent REDD+ "Beyond Carbon" approach .................................. 124

Figure 5.2 Map of Indonesian forest carbon stock ............................................................. 126

Figure 5.3 Mining concessions in relation to total carbon in Central Sulawesi..........127

Figure 5.4 Overlay of Indigenous territories and forest areas........................................ 130

Figure 6.1 Maps of forest cover in Papua Island ……........................................................... 152

Figure 7.1 The Bahanei Indigenous territory in Central Kalimantan ........................... 182

Figure 7.2 Process of manually drawing map of the Bahanei territory ........................ 187

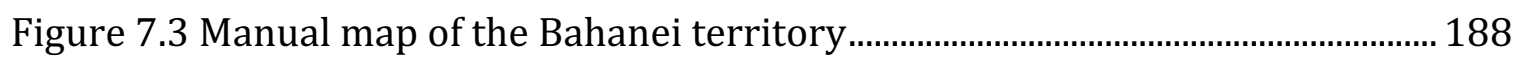

Figure 7.4 Zoning system in the Bahanei territory ……....................................................... 193 


\section{List of Tables}

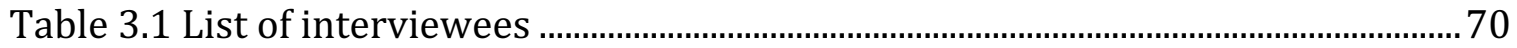

Table 3.2 REDD+ events observed ....................................................................................... 75

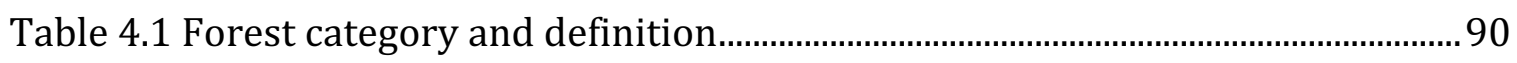

Table 5.1 Working Groups of the REDD+ Taskforce …........................................................ 116

Table 7.1 Zoning system in the Bahanei Indigenous territory ……................................. 191 


\section{List of Abbreviations and Acronyms}

ADB

AMAN

AMAN CK

APL

BAL

BAPPENAS

BFL

BIG

BRWA

CBD

CBNRM

CCB

CCBA

CERs

CIFOR

CITES

COP

ERC

EU

FCPF

FLEGT

FPIC

FWI

GHG
Asian Development Bank

Aliansi Masyarakat Adat Nusantara or the Indigenous Peoples Alliance of the Archipelago

Indigenous Peoples Alliance of the Archipelago in Central Kalimantan

Areal Penggunaan Lain or Other Land Uses

Basic Agrarian Law

Badan Perencanaan Pembangunan Nasional or National Development Planning Agency

Basic Forestry Law

Badan Informasi Geospasial or Geospatial Information Agency

Badan Registrasi Wilayah Adat or the Ancestral Domain Registration Agency

The Convention on Biological Diversity

Community Based National Resource Management

Community, Climate and Biodiversity

The Community, Climate and Biodiversity Alliance

Certified Emissions Reductions

Centre for International Forestry Research

The Convention on International Trade in Endangered

Species of Wild Fauna and Flora

Conference of Parties

Ecosystem Restoration Concessions

European Union

The Forest Carbon Partnership Facility

Forest Law Enforcement, Governance and Trade

Free, Prior, Informed Consent

Forest Watch Institute

Green House Gas 


\begin{tabular}{|c|c|}
\hline GIA & Geospatial Information Agency \\
\hline GIS & Geographical Information System \\
\hline GPS & Global Positioning System \\
\hline GtC & Giga ton Carbon \\
\hline HUMA & $\begin{array}{l}\text { Association for Community and Ecology-Based Law } \\
\text { Reform }\end{array}$ \\
\hline IAFCP & Indonesia Australia Forest Carbon Partnership \\
\hline IBSAP & Indonesia Biodiversity Strategy and Action Plan \\
\hline ICEL & Indonesia Centre for Environmental Law \\
\hline ICRAF & The International Centre for Research in Agroforestry \\
\hline IFCA & Indonesia Forest Climate Alliance \\
\hline IMM & Indicative Moratorium Map \\
\hline JAPHAMA & $\begin{array}{l}\text { Jaringan Pembelaan Hak-hak Masyarakat Adat or The } \\
\text { Indigenous Peoples Rights Advocacy Network }\end{array}$ \\
\hline JKPP & $\begin{array}{l}\text { Jaringan Kerja Pemetaan Partisipatif or Participative } \\
\text { Mapping Network }\end{array}$ \\
\hline KKN & $\begin{array}{l}\text { Korupsi, Kolusi dan Nepotisme or Corruption, Collusion } \\
\text { and Nepotism }\end{array}$ \\
\hline Kostrad & $\begin{array}{l}\text { Komando Cadangan Strategis Angkatan Darat or Army } \\
\text { Reserve Strategic Command }\end{array}$ \\
\hline LoI & Letter of Intent \\
\hline MEF & Ministry of Environment and Forestry \\
\hline MK 35 & $\begin{array}{l}\text { Keputusan Mahkamah Konstitusi No } 35 \text { or Constitutional } \\
\text { Court Decision Number } 35\end{array}$ \\
\hline MOA & Ministry of Agriculture \\
\hline MOE & Ministry of Environment \\
\hline MOF & Ministry of Forestry \\
\hline MRV & Measurement, Reporting and Verification \\
\hline NGOs & Non Governmental Organizations \\
\hline NICFI & The Norway's International Climate Forest Initiative \\
\hline NKB & Nota Kesepakatan Bersama or Joint Agreement Note \\
\hline NLA & National Land Agency \\
\hline NORAD & Norwegian Agency for Development Cooperation \\
\hline
\end{tabular}


OMI

Perber

PES

PRISAI

Pusdalkarhutla

RBI

REDD+

REL

RIL

RMU

RRC

SARA

Satlakdalkarhutla

SFM

SHK

TNC

UKP4

UN

UN-REDD

UNDRIP

UNFCCC

UNFF

UNORCID
The One Map Initiative

Peraturan Bersama or Joint Regulation

Payment for Environmental Services

Prinsip, Kriteria dan Indikator Safeguard Indonesia or Principle, Criteria, and Indicator of Indonesian Safeguard Pusat Pengendalian Kebakaran Hutan dan Lahan or the Land and Forest Fire Control Centre Rupa Bumi Indonesia or Basic Map of Indonesia

Reducing Emissions from Deforestation and Forest Degradation Plus

Reference Emissions Level

Reduce Impact Logging

Rimba Makmur Utama

Rimba Raya Conservation

Suku, Agama, dan Ras or Ethnicity, Religion, and Race Satuan Pelaksanaan Pengendalian Kebakaran Hutan dan Lahan or the Taskforce on Land and Forest Fire Control Sustainable Forest Management

Sistem Hutan Kerakyatan or Community Based Forestry The National Conservancy

Unit Kerja Presiden Bidang Pengawasan dan Pengendalian Pembangunan or President's Delivery Unit for Development Monitoring and Oversight

United Nations

United Nations - Reducing Emissions from Deforestation and Forest Degradation

The United Nations Declaration on the Rights of Indigenous Peoples

The United Nations Framework Convention on Climate Change

United Nations Forum on Forests

The United Nations Office for REDD+ Coordination in Indonesia 
WALHI

WWF
Wahana Lingkungan Hidup Indonesia or Friends of the Earth Indonesia

The World Wide Fund for Nature 


\section{Introduction REDD+ at the Intersection of Neoliberal and Not-Quite-Neoliberal Natures}

\subsection{Introduction}

“Get down...get down...!! Neoliberalism comprador!! Capitalism accomplice!!! Get down...get down!!! Comprador...comprador!!!"

This was what the crowds at the Indonesian Civil Society Forum for Climate Justice chanted at Emil Salim, Head of Indonesian Delegation at the United Nations Conference of Climate Change (UNFCCC) meeting in Bali in 2007. Emil Salim came to the activists' compound to calm down escalating tensions that had been brewing between a group of Indonesian activists and the government after several failed attempts to enter the negotiation site. I was amazed to witness some activists shouting loudly at a figure whose reputation commands widespread respect among domestic and international environmental activists. They were agitated by his speech that was questioning the activists' stand in rejecting the government's efforts in negotiating Reducing Emissions from Deforestation and Forest Degradation Plus (REDD+) as one of the key mechanisms in climate mitigation. In his speech, Emil Salim emphasised the need to collaborate with developed countries to tackle climate change as a global problem, a statement that triggered the accusation that he was an accomplice of the developed countries and a neoliberalism comprador (see media coverage in Detik.com, 2007; Kompas, 2007).

The chant grew louder and more insistent. A red faced Emil Salim left the stage and got into his car, no doubt feeling betrayed and humiliated. Later that night, I heard that some senior environmental activists came to Emil Salim's hotel room to apologize. According to one of these activists, this was done out of respect for Emil Salim's position as one of Indonesia's most trusted senior environmental activists, who, despite his busy schedule leading the negotiation, was nevertheless willing to come to calm down the tensions. The apology, however, also highlighted a tension between activists who were supporting Indonesia's REDD+ proposal and those who 
weren't (Hartiningsih and Arif, 2007). For opponents, REDD+ is part of the developed countries' ploy to colonize rainforests in developing countries. It functions as a capitalist machine for them to profit through carbon trading and evade their ethical responsibilities to reduce greenhouse gas emissions (watchindonesia.org, 2008). However, for others, REDD+ provides a political opening to articulate visions of transformation and justice in forest governance. These tensions and dynamics have rewritten Indonesia's forest politics and will be the focus of this thesis.

My curiosity about REDD+ was sparked by the above encounter. I was intrigued by the simple question of whether the REDD+ market mechanism could potentially solve the global environmental problems that have been caused by markets themselves. Since then, this simple question has transformed into multiple complex queries that inspire this $\mathrm{PhD}$ research. Paraphrasing Buscher, Dressler, and Fletcher's (2014) analysis of the neoliberalization of conservation practices, my academic inquiry starts with the question of whether REDD+ has the potential to address the capitalist market's own ecological contradiction? Can it be the terrain on which the seeds of ecological and social justice are sown within seemingly inhospitable neoliberal ideology?

In this thesis, I see REDD+ as an expression of neoliberal governmentality that is underpinned by the logic of market environmentalism (Beymer-Farris and Bassett, 2012; Stephan, 2012; Dixon and Challies, 2015; McGregor et al., 2015). It aims to incorporate market rationalities in governing the environment by advocating multiple win discourses oriented at overcoming climate crises, while acting as a biodiversity and poverty saviour (Angelsen et al., 2012; Gupta, 2012; Phelps, Friess and Webb, 2012, 2012). As a project of climate governance, however, REDD+ operates not only through market-based incentives but also disciplinary technologies expressed through the sovereign power of the state's juridical apparatuses.

This thesis will investigate how forest governance is being re-oriented through REDD+ governmentalities in Indonesia. It will do so by analysing at how REDD+, as a 
global environmental program, shapes and is shaped by the existing forest politics in Indonesia. I am interested to see how the state and non-state actors respond to the new opportunities and risks associated with REDD+. I do this by exploring the new technologies of forest governance that are being produced and employed to mainstream REDD+ rationalities and new subjectivities that are emerging on different scales around these politics. Through such an approach I hope to engage constructively with the debates between pro- and anti-REDD+ actors by seeing their positions that are fluid and contested.

I employ governmentality as the main theoretical framework to analyse how power/knowledge is used to problematize existing forest governance and support the production of new governmental technologies (Foucault, 2009; Winkel, 2012). I adopt a case study approach to analyse how REDD+ governmentality unfolds in particular places at particular times. Using three interrelated case studies, this thesis points to the importance of studying the empirical implementations of REDD+ to apprehend not only their discursive contestation but also their messy actualities.

REDD+ is defined by the United Nations-REDD Programme as "an effort to create a financial value for the carbon stored in forests, offering incentives for developing countries to reduce emissions from forested lands and invest in low-carbon paths to sustainable development" (un-redd.org, 2015). The spectacular ecological and economic benefits promised by REDD+ programme have compelled governments in tropical countries to initiate REDD+ readiness activities aimed at building infrastructures for implementation (Cerbu, Swallow and Thompson, 2011; Pistorius, 2012; Minang et al., 2014). In Indonesia, for example, REDD+ is positioned as the key to the country's transformation to a low carbon economy (Jupesta et al., 2011; Lal, 2012; Mulyani and Jepson, 2013). This is not without challenges from interministerial agencies and other actors, such as the Indonesian Palm Oil Association, as REDD+ is seen as a hindrance to the growth and expansion of agriculture and mining industries (Luttrell et al., 2012; Astuti and McGregor, 2015). Nevertheless, the head of Indonesia's REDD+ Taskforce has anticipated this contestation and links it to the way certain stakeholders perceive forests as merely a source of timber and land. He says that, "the old thinking has been with us for 40 years, [now we are 
developing] this new way of thinking" (Lal, 2014, p. 3), that sees economic benefits in trees standing rather than when they are cut down.

Shifting this old paradigm is one of the main pillars of Indonesia's REDD+ national strategy and employs a set of governmentalities to enact change. I refer to REDD+ governmentalities as the set of technologies, practices and activities oriented at guiding forest stakeholders' conduct towards forest carbon conservation (McGregor et al., 2015). In this thesis, I argue that REDD+ governmentalities are helping to render carbon and forests governable and apolitical entities. New scientific knowledges are being produced and those that can align with all these emerging norms, expertise and rules can benefit from new opportunities, while those that don't risk being marginalized and "let die" (Foucault, 1990).

This chapter provides an introduction to my doctoral thesis by outlining key themes. In the remaining four sections I first introduce the concept of REDD+ and link it to arguments regarding the neoliberalization of nature. In light of recent scholarly attempts to interrogate the variegated versions and ambiguity of post-neoliberalism (Bakker, 2013; McElwee et al., 2014; Anthias and Radcliffe, 2015; de Freitas, Marston and Bakker, 2015), I also discuss the possibility of studying REDD+ implementation in Indonesia as an expression of a not-quite-neoliberalization of nature. I draw on empirical studies that show how projects with neoliberal rationalities can be continuously shaped, co-opted and strategically repurposed to express broader socio-ecological justice interests. The second section introduces the two research objectives that underpin this study and briefly introduces three case studies that are being employed to illuminate the empirical study of REDD+ governmentality. The third section briefly examines REDD+ using a governmentality lens by highlighting its theoretical advantages in apprehending "neoliberalism as a discourse productive of a particular kind of society and particular kinds of subjects" (McCarthy and Prudham, 2004, p. 280). This theme is expanded upon in Chapter 2 as shown in the final section of the chapter that outlines the structure of the thesis. 


\subsection{Situating REDD+ in Indonesia}

REDD+ emerged as a response to the call to address global climate change. The destruction of the world's tropical forests is responsible for about $12 \%$ to $17 \%$ of total anthropogenic global carbon emissions (IPCC, 2007). Thus, REDD+ is expected to effectively tackle the dwindling of forest cover as well as act as an affordable mechanism to halt carbon emissions. REDD+ is a market mechanism works based on the logic that:

1) quantification of forest carbon stocks enables a mechanism to pay for measurable reductions in forest carbon emissions, 2) investors will pay for such reductions because they will be cost-competitive compared to other forms of emission mitigation, and 3) as a result developing countries will adopt REDD+ because it provides financial incentives for policies to maintain and sustainably manage forest resources more efficiently (Mulyani and Jepson, 2013, p. 2)

REDD+ was initially designed to focus on reducing emissions from deforestation forest degradation (REDD). However, the Bali Action Plan, agreed at the COP 13 meeting in Bali in 2007, proposed that a comprehensive approach to mitigating climate change should include "[p]olicy approaches and positive incentives on issues relating to reducing emissions from deforestation and forest degradation in developing countries; and the role of conservation, sustainable management of forests and enhancement of forest carbon stocks in developing countries" (UNFCCC, 2008). Three year later, at COP 16, as formulated in the Cancun Agreements, REDD was upgraded to REDD+, to reflect the inclusion of the role of conservation, sustainable management of forests and enhancement of forest carbon stocks in reducing forest carbon emissions (UNFCCC, 2011).

The specifics of a REDD+ mechanism continue to be negotiated under the UNFCCC, and the substantial financial costs for full-scale implementation have not yet been met either. A mandatory mechanism for REDD+ under the auspices of UNFCCC is therefore not yet in place or operating at scale. However, in response to this drawback, REDD+ initiatives have already been started under the umbrella of 
voluntary mechanism in anticipation of a formal one under the UNFCCC. Carbon credits coming from these REDD+ initiatives are sold in voluntary carbon markets. Voluntary carbon markets function outside of the compliance market (outside of UNFCCC). They enable industries, NGOs, governments, and individuals to offset their emissions by purchasing Verified Emissions Reductions (VERs) from voluntary REDD+ projects in the tropical developing countries.

In recent years, the Government of Indonesia (GoI) has taken steps to tackle environmental issues and climate change in which REDD+ plays a key role. Indonesia's interest to REDD+ was started in 2006 prior to COP 13 in Bali. Sponsored by the World Bank, and the British, Australian, and German governments, the MOF prepared a document detailing the potential of REDD+ in reducing carbon emissions from the land use and forestry sector. The MOF established a multistakeholder forum called Indonesia Forest Climate Alliance (IFCA) in July 2007 as a coordination centre for Indonesia's REDD related activities (IFCA, 2008). IFCA's most significant deliverables are the development of the Indonesian National Carbon Accounting System (INCAS) and the preparation for Indonesia's role as the host for UNFCCC'S COP 13 meeting that was to be held in Bali in December 2007. INCAS is a system of measurement, reporting and verification (MRV) specifically designed for the quantification of carbon reduction from REDD+ projects.

COP 13 in Bali brought a positive result for REDD+ by suggesting that all parties explore further actions and identify options to implement REDD+ through demonstration activities (see Decision 2/CP. 13 article 3). Follow up action was taken by the Government of Indonesia in collaboration with Australian Government through Indonesia Australia Forest Carbon Partnership (IAFCP) to develop a REDD+ demonstration activity in Central Kalimantan Province in 2008. Another REDD+ demonstration activity in Central Sulawesi Province was also underway through collaboration between the MOF and the UN-REDD Indonesia programme (Indarto et al., 2012). The aim of the demonstration activities is to enable the Government of Indonesia to identify the most effective mechanisms to reduce deforestation and forest degradation through sustainable management of forests. In addition to REDD+ demonstration activities, the MOF also developed Reference Emissions Level 
(REL) that is a benchmark for assessing Indonesia's performance in reducing carbon emissions. REL is expressed in tonnes of carbon dioxide equivalent per year. In 2009, the MOF issued Ministerial Decree No 36/2009 that outlines mechanisms on the distribution of income from the sale of carbon credits according to forest category. However, the Ministry of Finance has contested the decree and argued that the MOF has no authority and legal jurisdiction to govern REDD+ financial benefit sharing mechanisms (Ituarte-Lima, McDermott and Mulyani, 2014).

REDD+ is positioned as a key element in realizing Indonesia's pledge to reduce emissions by $26 \%$ by 2020 (or $41 \%$ reduction with international support) (Astuti and McGregor, 2015). The pledge then became official in 2011 when the President passed Decree No. 61 on the National Action Plan to Reduce Green House Gas Emissions. Since then, several international donors have offered their support to the Government of Indonesia (GoI) for its readiness activities. In May 26 ${ }^{\text {th }}$ 2010, a Letter of Intention (LoI) worth 1US\$ billion was signed by both the GoI and the Government of Norway under the Norway's International Climate and Forest Initiative (NICFI). The signing of the LoI has paved the way for the establishment of a REDD+ Taskforce through Presidential Decree No. 19, 2010, which aims to accelerate the national REDD+ readiness processes (Indarto et al., 2012). The head of the President's Delivery Unit for Development Monitoring and Oversight ${ }^{1}$ (Unit Kerja Presiden Bidang Pengawasan dan Pengendalian Pembangunan, hereafter UKP4), Kuntoro Mangkusubroto, was tasked to lead the REDD+ Taskforce.

The LoI outlines three phases of Indonesia's REDD+: preparation, transformation, and full implementation (Government of Indonesia, 2010b). The Taskforce's main role during the preparation phase was to develop the required policies and measures for REDD+ implementation in Indonesia. This phase is also known as REDD+ readiness - when a country builds its capacity, action plan, and strategy to be ready to implement REDD+. The LoI requires the establishment of a permanent REDD+ Agency, the appointment of REDD+ pilot provinces, the development of MRV

\footnotetext{
${ }^{1}$ UKP4 is a special ad-hoc body that was formed during President Yudhoyono's presidency to address silos among ministries and monitor the completion of national strategic programs. The UKP4 was heavily involved in REDD+ through the appointment of Kuntoro Mangkusubroto, the head of UKP4, as the head of the REDD+ Taskforce. Since then, UKP4 played a key role as REDD+ proponent in Indonesia.
} 
mechanisms, and the implementation of forest moratorium policy for Indonesia to receive performance-based payment from NICFI. Figure 1.1 below summarizes the transition of REDD+ implementation in Indonesia.

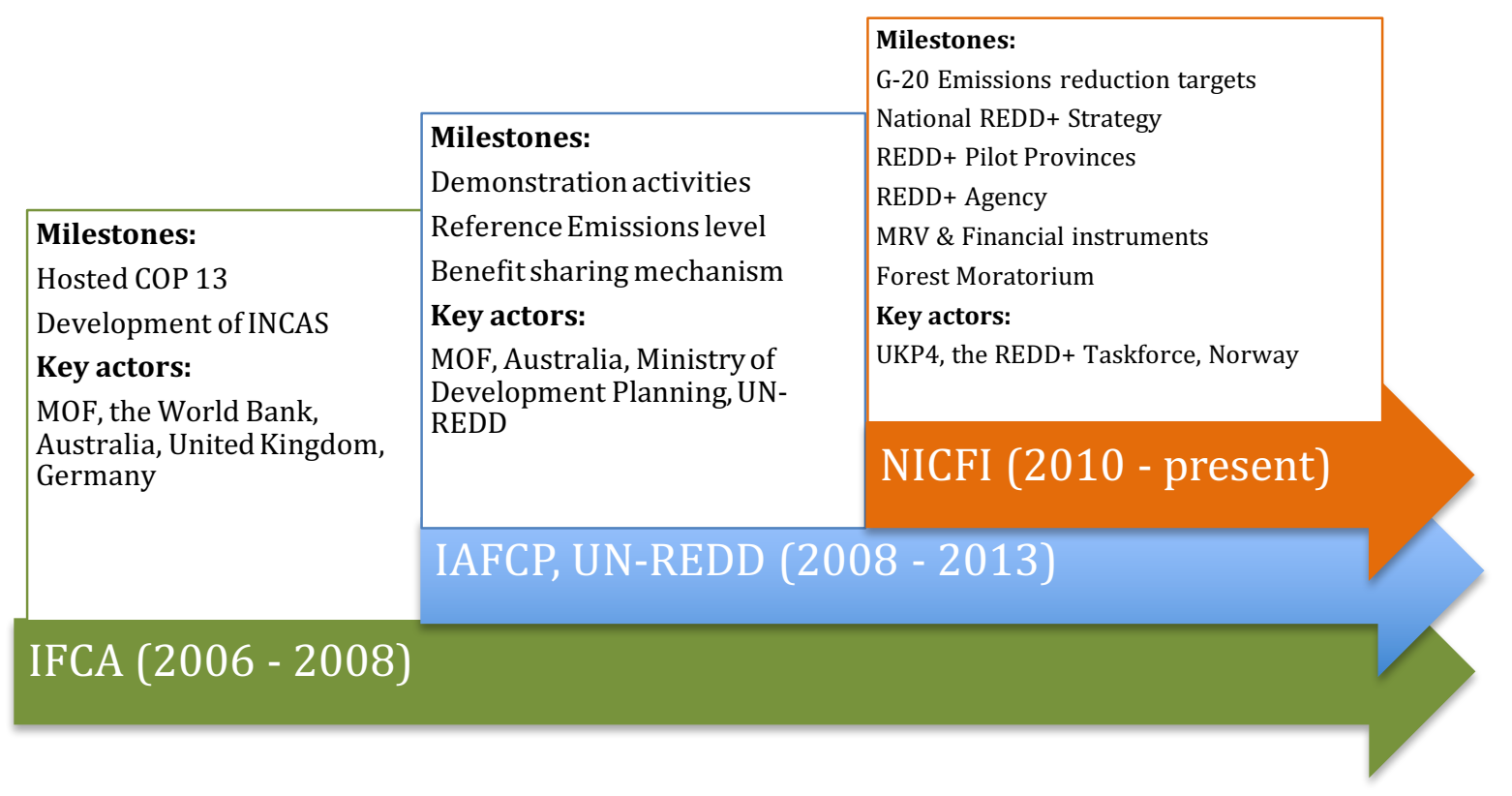

Figure 1.1 REDD+ transition in Indonesia

REDD+ initiatives, like those in Indonesia, are being unrolled across forested parts of the majority world. Hopes are high that REDD+ will provide a means of addressing forest emissions by creating financial incentives for improved forest management. Its negotiations, however, have proved controversial (Beymer-Farris and Bassett, 2012; Eilenberg, 2015) with a divide emerging between those seeking to develop practical mechanisms to implement the program, and critics concerned with issues associated with the neoliberalisation of nature (McGregor, 2010; Arsel and Büscher, 2012; Beymer-Farris and Bassett, 2012; Corson, MacDonald and Neimark, 2013; McGregor et al., 2014a). I discuss neoliberal critiques of REDD+ in the next section. 


\subsection{REDD+ and the Neoliberalization of Nature}

Economics scholars such as Friedman and Hayek, along with think tanks such as Mont Pelerin Society, promoted neoliberalism in the $20^{\text {th }}$ century as an ideology that is based on the reorganization of governance according to market rationalities (Peck and Tickell, 2007). Despite being one of the most powerful ideologies of contemporary society, neoliberalism is rarely defined in a consistent manner that shows one homogeneous and coherent explanation (Peck and Theodore, 2007; Brenner, Peck and Theodore, 2010a, 2010b). Rather than seeing this heterogeneity as a limitation, critical scholars analyse neoliberalism in its varied empirical and discursive expressions occurring at multiple geopolitical scales through diverse spatio-temporal practices and agencies (Liverman, 2004; Brenner, Peck and Theodore, 2010a; Castree, 2010a; While, Jonas and Gibbs, 2010; Bakker, 2013). As an ideology, neoliberalism emerges as a response to a perceived failure of the Keynesian model of governance, where the state is seen to have the main role in governing society and economy.

Critical debates on the increasing influence of markets in environmental management have led to the emergence of scholarly works on neoliberalization of nature (McCarthy and Prudham, 2004; Bakker, 2010; Castree, 2010b, 2010d, 2011; Arsel and Büscher, 2012). These works discuss the infiltration of market rationalities and capitalism in conservation practices and environmental governance and the ramifications of this for affected communities (Heynen and Robbins, 2005; Brockington and Duffy, 2010; Büscher et al., 2012). Environmental economists and multilateral institutions, such as United Nations Environment Programme (UNEP), advocate the concept of a green economy based on neoliberal principles as an alternative to unsustainable forms of economic development which do not value nature (Victor and Jackson, 2012; unep.org, 2015). For its defenders the green economy carries with it the healing pill to address what Polanyi refers to as capital's double movement. The term "double movement" is employed to describe a condition where the attempts to expand liberal capitalism are faced with various forms of resistance. In the context of nature commodification, the double movement refers to the contradiction between the rise of global economic growth and its 
inevitable side effects - the dwindling of the earth's resources and massive ecological destruction (Polanyi, 1944; Stroshane, 1997; Low, 2002; O’Hara, 2009).

Green economy campaigners see the pricing of nature's services and goods as a mechanism that will allow the incorporation of environmental externalities into production costs. In theory, this calculative mechanism will incite green business practices to proliferate. Ecological modernization explains that trade-offs between economic growth and environmental protection can be diminished through the adoption of calculative economic measures and efficient cross cutting technologies (Bäckstrand and Lövbrand, 2006).

Fairhead, Leach, and Scoones (2012, p. 242) note how notions of scarcity, loss and repair are employed to form what they call "the economic of repair" that is a paradigm in natural resources management that sees the "unsustainable use 'here' can be repaired by sustainable practice 'there'” (Fairhead and Leach, 2003; Leach et al., 2012). The economics of repair, according to Fairhead, Leach and Scoones (2012) proposes the double valuation of nature: "for its use and for its repair" (p. 242). This principle aligns with the banner of saving nature by putting a price tag on it (McAfee, 1999). What is problematic from this process of valuation is the potential for the appropriation of capital by actors who are interested in accumulating profits from the valuation of both the use of nature's services and the subsequent efforts to repair the nature's damages.

The economics of repair is the underlying principle of REDD+ carbon offsets. Activists often frame their opposition to REDD+ by highlighting the uneven policies that prolong privilege in northern countries to emit more carbon emissions as long as they can pay the developing countries to apply particular policies and measures that will ensure the cessation of deforestation and forest degradation (Bumpus and Liverman, 2008; Stephan, 2012; Stephan and Paterson, 2012; McGregor et al., 2014b). Furthermore, critics highlight that the concept of additionality (that is a principle that a particular offset project should have an additional benefit for reducing greenhouse gas emissions compared to the baseline situation where there is no project) is hard to prove in actual project implementation (Streck, 2011; van 
Oosterzee, Blignaut and Bradshaw, 2012). This is explained well by Welch (2007) who writes, "offsets are an imaginary commodity created by deducting what you hope happens from what you guess would have happened" (cited in The Guardian, 2007). At best offsets only postpone or displace environmental degradation from one place to another. Critics further caution that the valuation and commodification of carbon in REDD+ is not a neutral scientific undertaking, but rather political and value-laden processes which privilege particular knowledges and knowledge holders over others (Corbera, 2012; Gupta et al., 2012).

In the governance of nature, neoliberalism is advocating for the incorporation of market rationalities in the allocation of the world's resources in meeting people's needs by adopting principles such as efficiency, effectiveness, transparency, and competitiveness (Peck, 2010). The implementation of this ideology in managing the biophysical world can be achieved through what Heynen and Robbins (2005) classify as four streams of neoliberal nature practices: governance, privatization, enclosure, and valuation. Castree (2008a, 2008b) elaborates other strategies such as privatization, deregulation, re-regulation, marketization, commodification, flanking mechanisms in civil society, the creation of market oriented individuals and spatial expansion. These calculative technologies are mixed and combined to facilitate the re-institutionalization of environmental governance toward market rationalities. According to several scholarly views these practices tend to aggravate existing social inequalities and disadvantage the poor (Harvey, 2006, 2009; Castree, 2010a, 2011). Employing a Marxist perspective, Harvey (2009) points to the political intention of the elites in the society of using neoliberalization as a mechanism of accumulating profits and retaining authority at various scales (Harvey, 2009, p. 19; Peck, 2010).

Drawing on Polanyi's notion of "fictitious commodities", Castree (2010c) explains the process when particular ecosystem services are detached from their complex ecological system to render them visible and quantifiable and therefore tradable (Polanyi, 1944; Castree, 2010c). Polanyi coined the term "fictitious commodities" to describe any commodities (nature, workers, etc) which are subjected to devaluation process within a capitalist system. That is to say, that the real values of these commodities exceed those values assigned by the market. According to Castree 
(2010c), nature's ecosystem services, such as carbon sequestration, are impossible to be equated purely with monetary values, as ecosystems also hold intrinsic social, cultural, and biological values. The valuation of environmental services thus can cause the restructuration of human - environment relationships in a way that simplifies the complexities of the relationship into a mere monetary expression (Corbera, 2012). Other criticisms of the neoliberalization of nature emerge from Marxist thinking that problematizes the ramification of neoliberalization on the principle of distributive justice in resource allocation (McCarthy and Prudham, 2004; Harvey, 2009; Arsel and Büscher, 2012). In the context of REDD+, for instance, the new economic opportunity from carbon commodification is legitimising the formation of new agencies and governance that could lead to these new agencies cornering a disproportionate share of REDD+ financial benefits while further marginalising the poor, leading to what Harvey, (2009) terms "accumulation by dispossession". Several scholars working on issues of green grabbing draw on Harvey's notion to understand the linkage between processes of capital accumulation and territorialisation (Benjaminsen and Bryceson, 2012; Fairhead, Leach and Scoones, 2012; Holmes, 2014). Green grabbing is the process by which lands are enclosed and their rightful owners are displaced for the purposes of capital accumulation, which usually intersects with the concept of nature commodification.

The proliferation of market hegemony is usually accompanied by lesser state interferences in distributing nature's goods and services (McCarthy and Prudham, 2004). This is not to say, however, that states lose their significance. Instead they emerge with new roles to develop market friendly laws and regulations and ensure the endorsement of such policies, albeit tainted occasionally with cronyism and political collusions (Castree, 2011). In explaining neoliberalism as state governmental strategy, Foucault (2009, p. 132; cited in Fletcher and Breitling, 2012) eloquently warns scholars that, "neoliberalism should not be identified with laissez faire, but rather with permanent vigilance, activity and intervention". In this thesis then, while paying attention to non-state actors' involvements in REDD+, one of its core concerns is investigating how the GoI has attempted to normalize REDD+ market mechanisms as a calculative technique in governing Indonesia's forests. 
Proponents of neoliberal nature advocate for the potentiality of market mechanisms in providing additional livelihood opportunities for rural and forest dependent communities (Wunder, 2001; Kerr, 2002; Pagiola, Arcenas and Platais, 2005; Bulte et al., 2008; Engel, Pagiola and Wunder, 2008; Jindal, Kerr and Carter, 2012). Conversely, McAfee (2012) asserts that market environmentalism cannot go hand in hand with poverty alleviation, as often the principles of efficiency and effectiveness significant to a markets oppose poverty alleviation initiatives. Critical scholars warn of the emergence of "inclusionary neoliberalism" as a deceptive mechanism that tries to hide the ideology of capitalism behind the curtain of caring and inclusive neoliberal nature (Weyland, 2003; Fletcher and Breitling, 2012; McAfee, 2012). Milne and Adams(2012) call this process a market masquerade. REDD+ as market environmentalism is seen by its critics as being built upon an image of inclusive mitigation that offers benefits not only for climate change mitigation, but also biodiversity protection and poverty alleviation.

As explored above, critical scholars discuss the ramifications of the escalating growth of the neoliberalization of nature in environmental governance by drawing on concepts such as marginalization, justice, and hegemony. Most of these literatures however tend to adopt a perception that the neoliberalization of nature is homogeneous and static, and as such, oppressive and hegemonic (K. Bakker, 2009). Castree $(2010 \mathrm{~d})$ cautions scholars not to be trapped in this rather premature analysis and for them not to jump to a conclusion coming from a shallow investigation that overlooks the underlying political context of a particular case. Drawing on this advice, the next section discusses the emerging concept of notquite-neoliberal nature as a new way of seeing the grounded implementation of neoliberal nature that, given the right political condition, can potentially become the seeds for progressive transformation.

\subsection{REDD+ and Not-Quite-Neoliberal Nature}

Following Foucault's post-structuralist approach, I view neoliberalization in environmental governance as manifested not only in the economic principles of 
governance but expressed in all aspects of human and environment relationships, be they social, cultural or political. Thus, one can argue that neoliberalism is an ideology that works by shaping our way of thinking and being a "general style of thought, analysis and imagination" (Foucault, 2009, p. 218 cited in Fletcher and Breitling, 2012). This ideology aims to produce rational neoliberal subjects whose decisions regarding particular actions are based upon their capacities to identify any possible risks and opportunities and whom in the end can be held accountable for any possible impacts (Dean, 2009; Fletcher, 2010). In such a view, neoliberalism is not necessarily oppressive but selectively empowers particular subjectivities and forms of action (Dean, 2009).

Based on grounded analysis of several neoliberalization of nature projects in Latin America, de Freitas, Marston and Bakker (2015, p. 4) develop a concept of "notquite-neoliberal nature" to explain the variegated "ambiguity of putatively postneoliberal responses, given that they may be simultaneously strategic, co-opted, and counter-hegemonic". The three authors edit a special issue of the journal Geoforum, which was published in July 2015, and point to three similar themes that repeatedly emerge throughout the articles that characterize not-quite-neoliberal nature projects: 1) concomitant and evolving political processes, 2) tensions and contradictions, and 3) dynamism. In explaining concomitant and evolving political process, de Freitas, Marston and Bakker (2015) highlight how contributors in the issue broaden their analysis beyond the neoliberalization-centric account by capturing the multifaceted political and socio-natures context in which their projects unfold.

Anthias and Radcliffe (2015) provide an example of a not-quite-neoliberal nature project from the Indigenous ${ }^{2}$ territorial struggle in Bolivia to demand special rights to own land by subverting a neoliberal nature project. The authors argue that the special titling demanded by a Bolivian Indigenous communities to divide citizenship and give them specific land title is not a racial policy that discriminates against and render these communities unfit to manage lands but more of a strategy to tackle the

\footnotetext{
${ }^{2}$ Adjective "Indigenous" is capitalised throughout the thesis as a form of recognition to the formation and struggle for international Indigenous identity (Johnson et al., 2007)
} 
"dispossessionary effects of capitalism" (Anthias and Radcliffe, 2015, p. 5). They further argue that the governmental schemes employed by NGOs and Indigenous communities to protect their territory through the marketization of high conservation value areas has created spaces for a more radical Indigenous movement rather than resulting in neoliberal co-optation of Indigenous subjectivities. They use the term "ethno-environmental fix" to explain governmental techniques applied by NGOs and Indigenous communities, expressed through articulation of green Indigenous subjectivities and territorialisation, as a struggle against land appropriation.

The same situation can be observed in Indonesia, the Indigenous Peoples Alliance of the Archipelago (AMAN) ${ }^{3}$ succeeds in centralizing discourse on Indigenous tenure rights in the national REDD+ debates (Agung et al., 2014; Astuti and McGregor, 2015). Aligning with the REDD+ Taskforce's intention to produce governable spaces and subjectivities for REDD+ implementation, AMAN secured support from the REDD+ proponents for their Indigenous mapping programmes. Donors lined up to support AMAN's efforts to secure and clarify conflicts over Indigenous land tenure for successful carbon conservation implementations. This example reveals that political spaces in environmental governance can be claimed from below. The example also points to the first theme that de Freitas, Marston and Bakker (2015) explain, that is, the multifaceted context where a neoliberal project unfolds, and underlines the significance actor agency in shaping the project.

Tensions and contradictions are the second theme that can be found easily in the not-quite-neoliberal nature projects (de Freitas, Marston and Bakker, 2015). The tensions and contradictions arise, for instance, from the differences, inconsistencies and incongruities of laws, regulations, and norms at multiple scales that are being utilised by actors to serve their interests (de Freitas, Marston and Bakker, 2015). In the context of REDD+ governance in Indonesia, activists mobilised a campaign to scrutinize the forest moratorium processes, meaning the cessation of the issuance of new forest concessions for any types of forest investment activities except for new

\footnotetext{
${ }^{3}$ AMAN is a national non-profit organization whose focus is to struggle for Indonesia's Indigenous peoples to get recognition of their identities and rights.
} 
carbon forestry projects and for activities that are seen to have a great positive impact to the society. From a Marxist perspective, the moratorium can be seen as the state's spatial fixes to generate governable spaces for market environmentalism projects (Harvey, 1999), while on the other hand the moratorium is claimed by environmental activists to be pushing the agenda of reform in Indonesia's forest governance (see Chapter 6). The moratorium facilitates a new level of transparency and public participation, thus enabling a process of criticism and control. Chapter 6 discusses these contradictions using the case study of the One Map Initiative (OMI). Following de Freitas, Marston and Bakker (2015, p. 5), I position these tensions and contradictions as a possibility for "generating the potential for transformation" and justice.

The last characteristic of not-quite-neoliberal nature is dynamism (de Freitas, Marston and Bakker, 2015). Reflecting on REDD+ implementation in Indonesia, the REDD+ Taskforce promotes the tagline "Beyond Carbon, More than Forest" to emphasize that non carbon benefits are the main interest of the GoI (see Chapter 5). This strategy has proven effective in assembling wider support from Indonesia's civil society. While the civil society's engagement is the source of legitimacy for the REDD+ Taskforce's authority, for activists this is seen as the opportunity to claim political space in order to be more involved in the policy making processes (see Chapter 5). This dynamism of REDD+ implementation in Indonesia has prompted various discussions on the impact of REDD+ readiness activities in advancing an agenda for forest governance reform (see Chapters 5 and 6). Indeed, de Freitas, Marston and Bakker (2015, p. 5) have highlighted that "to foster social change - or merely favourable conditions - actors may be forced to sow the seeds in seemingly inhospitable conceptual terrain or cultivate its early instars to mimic would-be predatory ideologies" (see also Pieck, 2015). Dynamism allows actors to continually shape projects and policies that are strongly influenced by neoliberal ideology. It creates spaces for political manoeuvring that are essential for actors to pursue their interests (de Freitas, Marston and Bakker, 2015; Pieck, 2015). Taking into consideration the dynamism, tensions, and contradictions of REDD+ implementation in Indonesia, this research adopts this not-quite-neoliberal perspective to analyse REDD+ governmentalities in Indonesia. 


\subsection{Research Objectives and Questions}

Taking into account the theoretical discussion above and drawing from three interrelated case studies on REDD+ implementation in Indonesia this research is guided by two objectives:

1. To examine how REDD+ governmental technologies are being developed, applied, and contested, and with what effects, within three different case studies.

\section{a. Case study 1: the REDD+ Taskforce}

To examine a selection of governmental technologies (or a set of means, techniques, mechanisms, procedures, tactics) being developed and applied by the REDD+ Taskforce to mainstream REDD+ in Indonesia - particularly at the national scale. The case study focuses on the participatory technologies being developed, the politics surrounding these technologies and the new subjectivities emerging.

\section{b. Case study 2: the One Map Initiative (OMI)}

To analyze the production and application of OMI as a governmental technology employed to produce governable space for REDD+ investment. The case study focuses on the design of OMI and the selective engagement by activists seeking to reorient OMI towards more progressive forest governance.

\section{c. Case study 3: an Indigenous land claim assemblage}

To track how REDD+ technologies are contributing to the formation of new political conjuncture in forest governance and to subsequently trace the effect of this new conjuncture to a particular Indigenous land claim assemblage in Central Kalimantan.

2. To examine REDD+ governmental technologies using a not-quite-neoliberal nature framework in order to identify constraints but also remain open to 
strategic and progressive possibilities embedded in this mechanism of forest governance reform.

To answer the above questions, this study engages with the theory of governmentality which I will briefly introduce in the following section and elaborate in Chapter 2. The three case studies were chosen through a process of following the translation of the metaphor "Beyond Carbon, More than Forest". This metaphor was created by the REDD+ Taskforce to politically declare that instead of exclusively focusing on carbon offsets, REDD+ is to be symbolically employed to advance the forest governance reform and low carbon economic development in Indonesia. The three case studies represent the key sites where the metaphor is being translated into REDD+ governmental technologies (see Chapter 3).

The thesis is informed by Anna Tsing's (2005) ethnography of global connection. I study the "friction" or awkward interconnections across geographical scales, actors and political difference. Case study 1 on the REDD+ Taskforce represents the interconnection between REDD+ global discourses and its translation and normalization at the national scale. Case study 2 on OMI sketches the production of "technological fixes" and its messy actualities at the national and district levels (Scott, 1998; Li, 2005). This case study also illustrates the agency of non-state actors in proposing an alternative to the state's technological fixes. The final case study on Indigenous land claims shows the awkward engagement between local actors struggling against land appropriation and REDD+ proponents' interest in producing governable spaces and pro-REDD+ subjectivities. Chapter 3 will provide a detailed explanation of the three case studies and the research methodology. Each of the case studies will be addressed in Chapters 5, 6 and 7 respectively.

The research is also informed by the work of geographers Julie Graham and Katherine Gibson (hereafter referred to as Gibson-Graham, their joint pen name) who emphasize the notion of hopeful geographies - to not be rendered powerless by naming neoliberal ideologies but to instead focus our energies on producing and highlighting alternatives (Gibson-Graham, 2005, 2008). Drawing on these politics of hope and the not-quite neoliberal nature framework, Chapter 8 discusses the second 
objective of the research that aims to understand how REDD+ is being co-opted, challenged and subverted by diverse actors to carry within it the socioenvironmental justice agenda that challenges simple neo-liberal readings. The remainder of this chapter introduces the concept of governmentality and lays out the structure of the thesis.

\subsection{REDD+ Governmentality}

Governmentality is a theoretical approach introduced by Foucault in the 1970s that has re-oriented thinking about governance and power. Governmentalities can be understood "in the broad sense [as] techniques and procedures for directing human behavior" (Foucault, 1998, p. 82). Stripple and Bulkeley (2013b, p. 32) explain that "governmentality deals with how particular mentalities - or ways of thinking and acting - are invested in the process of governing". In order to understand governmentality as a form of power scholars have to examine its empirical articulations through the investigation of governmental rationalities and programmes (Dean, 2009). In the context of environmental governance, governmentality has been widely applied in the examination of climate governance (Bäckstrand and Lövbrand, 2006; Lövbrand and Stripple, 2011; Stripple and Bulkeley, 2013a; Astuti and McGregor, 2015; McGregor et al., 2015), forest policies (Winkel, 2012), carbon economies (Lovell and Liverman, 2010; Descheneau and Paterson, 2012; Dixon and Challies, 2015), carbon science and modeling (Lövbrand, Stripple and Wiman, 2009; Gupta et al., 2012), and climate risk and adaptation (Oels, 2005).

Following Stripple and Bulkeley (2013b), I argue that engaging governmentality in investigating REDD+ enables us to see government as a "hybrid, non-hierarchical and network-like mode of governing" (p. 28). In doing so, it denies the centrality of the state's role in the process of governing and opens up the growing role of non-state actors in REDD+ politics. Governmentality analysis sees power as diffuse and immanent, enabling scholars to problematize the dichotomy between the public and the private and between state and non-state (Stripple and Bulkeley, 2013b, p. 35). Instead environmental governance is seen as a contested terrain that is shaped by 
diverse interests and tensions (Bäckstrand and Lövbrand, 2006). Through governmentality, we see governing not as a totalizing activity but various attempts aimed at managing humans and their relations with things through technologies and discursive practices (Dean, 2009; Foucault, 2009; Walters, 2012).

The inclusion of the private sector and other actors in governing the environment have triggered extensive scholarly debates on advanced liberal government as a mode of governance (Oels, 2005; Bäckstrand and Lövbrand, 2006; Bulkeley and Schroeder, 2012). Governmentality helps in investigating the emergence of governmental assemblages in new sites and facilitates the examination of its implications and impacts (Fletcher, 2010; Stripple and Bulkeley, 2013a; McGregor et al., 2014b). In using governmentality theory to analyse climate change governance, Stripple and Bulkeley (2013b) argue that governmentality provides critical scholars with a toolbox to "grasp and highlight the existence of changing discursive production of a warming world and its effects in mitigating or adapting to that world" (p. 33).

There are two ways of understanding governmentality: as a form of power and as an analytical framework (Lövbrand and Stripple, 2013). As a modality of power, governmentality is loosely defined as a set of practices and technologies to enable population and subjects to govern others and themselves (Foucault, 1998, 2009; Dean, 2009; Lövbrand and Stripple, 2013). On the other hand, as an analytical tool, governmentality is described as, seeking to identify these "different styles of thought, their conditions of formation, the principles and knowledges they borrow from and generate, the practices they consist of, how they are carried out, their contestations and alliances with other arts of governing" (Rose, O'Malley and Valverde, 2006, p. 84 cited in Lovbrand and Stripple, 2013).

This thesis engages with both notions of governmentality. In doing so I employ governmentality as a means to ask about a way of government that pays particular attention to the relationship between the construction of truth and the production of governmental techniques in REDD+ implementation in Indonesia (Lövbrand and Stripple, 2013). In this case, governmental techniques are forms of self- 
enhancement technologies that are designed to systematically allow subjects to regulate their conduct according to the REDD+ discourses, for instance, discourses on green economy and low carbon development.

Dean (2009) highlights that governmentality scholars ask the how of the government rather than the who. Rose and Miller (1992) point to the importance of analysing "rationalities of government" that shape the way government is being conducted and "technologies of government" through which rationalities are applied (Barry, Osborne and Rose, 1996). To study rationalities of government, we need to investigate the discursive fields upon which forms of knowledge are represented and employed (Lövbrand and Stripple, 2013). To investigate technologies of government, scholars have to look at diverse assemblage of technologies, material artefacts and tools that make the conduct of conduct operable (Lövbrand and Stripple, 2013). These can be done through analyzing maps, diagrams, accounting and statistical methods that are used in rendering visible the object of governance as something that is measurable and governable (Scott, 1998; Demeritt, 2001; Li, 2007c; Edwards, 2010). In the context of REDD+, for instance, researchers focus on forest carbon through the representational techniques used by scientists and climate economists (Baldwin, 2003).

Through what Lovbrand and Stripple (2011) call the "analytics of carbon accounting", they pay attention to how carbon is turned into objects of governance in three different governmental domains: "the national carbon sink"; the "carbon credit", and "the personal carbon budget", to render visible the governmental technologies applied in shaping human behaviors in each of these domains. These processes of ordering, classifying, and representing constitute "particular ways of seeing, knowing and acting upon nature at particular times in history" (Stripple and Bulkeley, 2013b, p. 33). For example Stephan (2012) and Edward (2010) underline the advancement of technology in climate science such as remote sensing and GIS software that facilitate the depiction of land use change and its impacts on the amount of forest carbon emissions. These technologies have helped in enabling the governance of human activities relating to land use changes. 
Emerging literature on neoliberal governmentality focuses attention on the process of subjectification, or the production of new subjectivities (Paterson and Stripple, 2010; Rice, 2010). As a form of power, governmentality's key feature is the notion of "self-government", that is the process through which individuals are motivated to behave and act according to state objectives without coercion or force but because it is seen in their own self-interest (Dean, 2009). Paterson and Stripple (2010) outline the proliferation of practices and technologies that target individuals and companies to adopt what they call "carbon conduct". This type of governmentality shapes how people think and act in order to reduce carbon emissions. A classification system is employed to embed individual behavior with certain types of actions, such as carbon dieters, emitters, displacers, or traders (Paterson and Stripple, 2010; Bulkeley and Stripple, 2013) and encourage them to adopt and shift their subject positions. Skoglund (2014) calls this ideal vision of a subject position "homo clima", or selfregulating actors based on carbon metrics (Rutland and Aylett, 2008), or carbonconscious consumers (Goede and Randalls, 2009). Policy makers and activists often employ discourses of apocalyptic imaginaries to motivate changes in human conduct and subjectivities (Methmann and Rothe, 2012).

In linking previous discussions on neoliberal nature, REDD+ and governmentality there has been a tendency to interpret many matters of REDD+ policies as expressions of a neoliberal rationality. Blok (2013) cautions however, about generalizing all the narratives of environmental policy into one totalizing story of neoliberal policy as this denies plurality and contestation within the production of governmentalities. Instead governmentality can be seen as an assemblage that is unfinished and always in the making. Studies of governmentality can challenge the perceived fixedness and rigidity of REDD+ as dogmatic governmental system from above. Instead REDD+ governance is embedded in an evolving assemblage of differently positioned and competing actors.

Seeing the (not quite) neoliberal governmentalities through this lens directs attention to how government takes place, the diversity of actors and interests involved, and the new subjectivities being produced and contested. The concept of not-quite-neoliberal nature helps recognizes the agency of actors, tensions, 
contradictions and the particular place based political dynamism in the production of governmental technologies. This helps avoid becoming prematurely trapped in oppressive homogeneous narratives of hegemonic neoliberal systems.

\subsection{Chapter Outline}

This chapter has introduced the concept of REDD+ through the lens of neoliberal nature, not-quite-neoliberal nature and governmentality. The remainder of the thesis will be divided into seven chapters with four chapters detailing the core findings of the thesis. Following Anna Tsing's (2005) ethnographic approach that focuses on the cross scale and "awkward engagement" of diverse elements, this thesis presents a particular multiscalar analysis of REDD+ governmental assemblages in Indonesia.

In the subsequent chapter, I deepen my review of Foucault's genealogical understanding of power and draw upon Dean's (2009) governmentality framework to further the conceptual framing of this thesis. This chapter explores how governmentality scholars study a particular governmental regime. It focuses on rationalities of government; fields of visibility; technologies of government; the production of knowledge; the creation of new subjectivities; process of problematization and rendering technical - and applies them to the field of green or environmental governmentalities. These elements underpin the investigation of the case studies in the three core empirical chapters of the thesis.

Chapter 3 lays out the methodological approach and discusses my positionality and reflexivity. Drawing on a poststructuralist approach and Gibson-Graham's notion on hopeful geography research, I reflect on the process of fieldwork, data collection methods, and analysis employed. Furthermore, by claiming a political position as a scholar activist, I reflect on my positionality as part of REDD+ governmental assemblage that I studied. This reflective approach has helped to expand my understanding on REDD+ governmental assemblages in Indonesia. 
Chapter 4 provides the broad political, ecological and economic context in which this research is conducted by exploring the general implementation and overview of forest governance in Indonesia. It reviews the historical process of land appropriation from Indigenous peoples and forest dependent communities, conducted or sponsored and legitimized by the state apparatuses. The chapter also charts the process of REDD+ inception in country. This chapter demonstrates that REDD+ in Indonesia is not implemented in a vacuum but rather has to negotiate with and be shaped by existing political ecologies.

The subsequent three core chapters (Chapters 5, 6 and 7) report on the case studies with earlier versions all submitted as co-authored journal articles ${ }^{4}$. Chapter 5 examines focuses on three participatory governmental technologies employed by the REDD+ Taskforce to mainstream carbon rationalities at the national scale. These are processes of communicating; visualisation; and engagement. Particular attention is devoted to the evolution of the concept of "Beyond Carbon, More than Forest". This tagline has enabled openings for activists to critically engage broader REDD+ audiences with issues of justice and governance reform rather than to solely focus on market mechanisms and carbon offsets. However the chapter also warns of the possibility of depoliticisation through an analysis of activist subjectivities that are

\footnotetext{
${ }^{4}$ An earlier version of Chapter 5 has been published as an article in the journal Asia Pacific Viewpoint and co-authored with Andrew McGregor. See Astuti, R., \& McGregor, A. (2015). Governing carbon, transforming forest politics: A case study of Indonesia's REDD+ Task Force. Asia Pacific Viewpoint, 56(1), 21-36.
}

An earlier version of Chapter 6 has been accepted as an article in the journal Third World Quarterly and co-authored with Andrew McGregor. See Astuti, R. \& McGregor, A. (Accepted). Responding to the Green Economy: How REDD+ and the One Map Initiative are Transforming Forest Governance in Indonesia. Third World Quarterly.

An earlier version of Chapter 7 has been reviewed and resubmitted as an article in Journal of Peasant Studies and co-authored with Andrew McGregor. See Astuti, R. \& McGregor, A. Assembling Indigenous Land Claims or Land Grabs? Opportunities and Constraints in Indonesia's New Forest Carbon Political Conjuncture. Journal of Peasant Studies.

The three chapters are the extended version of the submitted articles. They contain greater empirical data and broader discussions of theoretical framework. I was solely responsible for the research fieldwork, data analysis and first full drafting and final versions of the manuscripts of the articles. Andrew McGregor as a co-author/supervisor has generously provided feedback, minor editing and suggestions for the three articles. 
becoming more open to the complexities of forest bureaucracies and more permissive of the government's inability to perform.

Chapter 6 draws on the case study of OMI, a technical response to the messiness of forestland governance where there is no clarity over who has the rights to land, and where and what kind of forest activities are permissible. By closely analysing three technologies of government under the banner of OMI, I reveal the efforts of the REDD+ proponents made to problematize current forest governance practices and in doing so legitimize new technologies that they propose and expect to produce governable spaces for market environmentalism. Taking the inspiration from Scott's (1998) ontological approach in Seeing Like a State and extending it with Li's (2005) concept of looking beyond state failure, this chapter shows how the process of rendering technical can be resisted, co-opted and subverted to incorporate issues of Indigenous tenure rights and Indigenous spatial knowledge in the governance of Indonesia's forestland.

Chapter 7 assesses the impacts of forest carbon politics by connecting changes in forest governance with the assembling of an Indigenous land claim. By combining governmentality, territoriality and assemblage approaches, this chapter is able to analyse diverse discursive and material practices that are required to assemble a land claim. The chapter also contributes to the current scholarly debates on land grabbing that, among others, is associated with carbon conservation projects such as REDD+ (Borras et al., 2011; Fairhead, Leach and Scoones, 2012; Margulis, McKeon and Borras, 2013). By looking into its grounded and messy actualities, this chapter problematizes the assumed divide between land claims and land grabs, in which the benevolent intention of the former can (un)intentionally transform into a form of land appropriation and grabbing (Hall, Hirsch and Li, 2011). Hence the chapter is hopeful but cautious about the grounded outcomes of REDD+ governmentalities for emancipatory forest politics.

Chapter 8 recalls the research objectives and the findings of the study and discusses them in the relation to current debates on neoliberal and not-quite neoliberal nature. In concluding the thesis, I present the contribution this thesis proposes to 
make to REDD+ theory and practice. I argue that REDD+ should be seen as an arena of struggle that works in contradictory and complex ways.

Figure 1.2 below summarizes the thesis chapters and illustrates the overall structure of the thesis. 
Chapter 1: Introduction

- Introduction to REDD+ through diverse frameworks: neoliberal nature, not-quite neoliberal nature and governmentality

- Outline of research objectives and questions

Chapter 2: Theoretical framework

- Outline of Foucault's ontological understanding of power

- Explanation of governmentality as an analytical framework for analysis in Chapters 5, 6, 7 and 8

Chapter 3: Methodology

- Description on the political framing of the thesis as a hopeful and critical research inspired by Gibson-Graham's works

- Outline of multi-sited and multi-scalar ethnographic methodology

- Reflections on positionality of the researcher as a scholar activist

Chapter 4: Context

- Outline of the political ecology and economics context in which this research is conducted

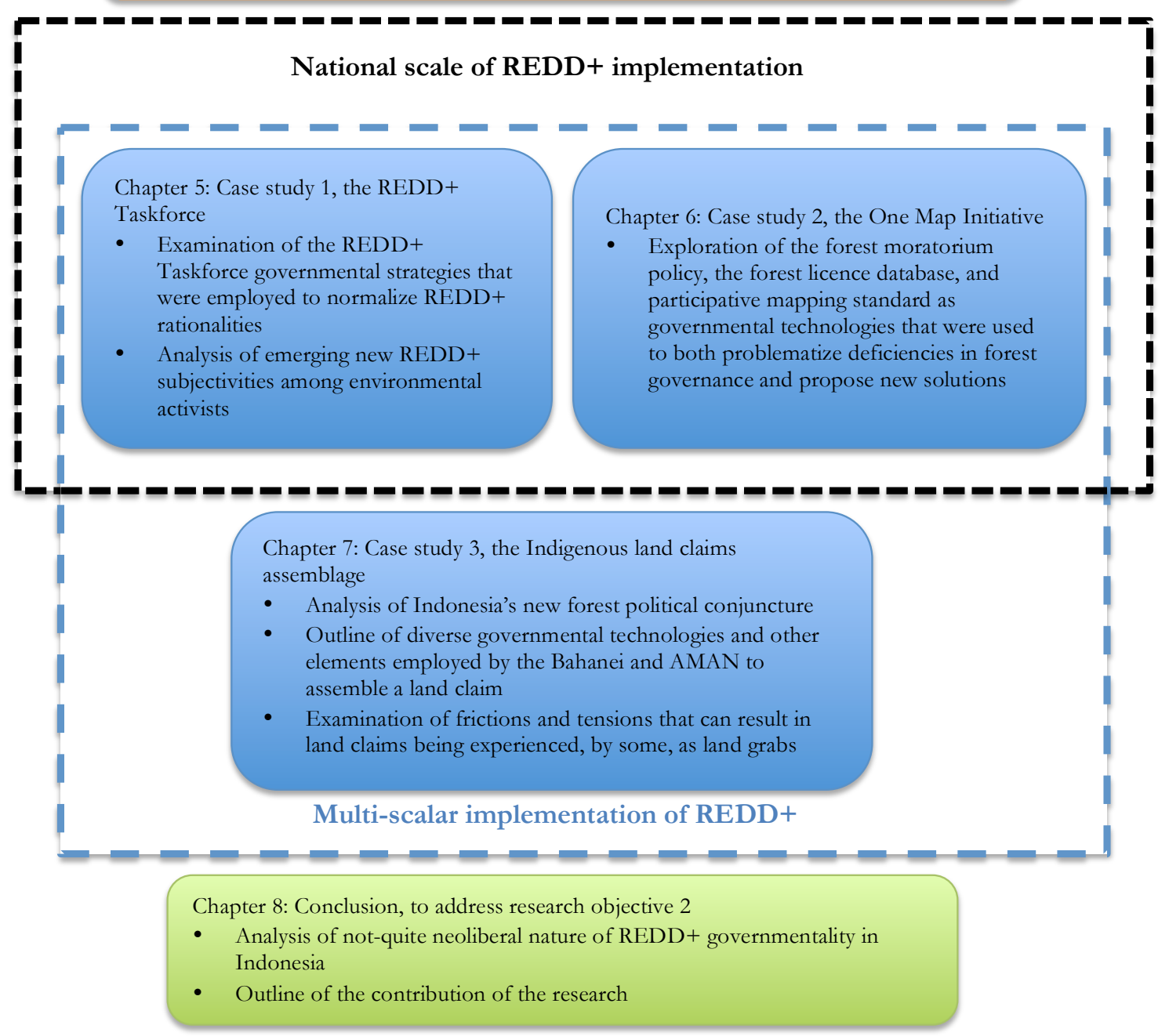

Figure 1.2 Thesis structure 


\subsection{Conclusion}

This chapter has sought to introduce the theoretical approaches, research objectives, and outline of the thesis. The chapter began with a description of the researcher's political motivation in pursuing this study. The chapter then continued with exploration of REDD+ through the concepts of neoliberalization of nature, and not-quite-neoliberal nature and governmentality. The three concepts have provided sufficient background for the introduction of the research objectives and questions. To better grasp the approach of this study, I have briefly outlined the three case studies that underpinned this empirical research and introduced this study as a hopeful yet critical inquiry. A short discussion on governmentality in the subsequent section was intended to introduce the main theoretical framework and provide the opening for the next chapter. The chapter is concluded with the outline in Figure 1.2 that provides the road map to navigate through the eight chapters that make up this body of scholarship. 


\section{Theoretical Review The Art of Governing Human and Forest Relationships}

What does it mean to govern a ship? It means clearly to take charge of the sailors, but also of the boat and its cargo; to take care of a ship means also to reckon with winds, rocks and storms; and it consists in that activity of establishing a relation between the

sailors who are to be taken care of and the ship which is to be taken care of, and the cargo which is to be brought safely to port, and all those eventualities like winds, rocks, storms and so on; this is what characterizes the government of a ship (Foucault, 1991a, pp. 93 - 94).

\subsection{Introduction}

Foucault (1991a, p. 93) employed the above illustration on governing a ship to explain the core concept of government. Following Guillaume de la Perriere, he defined government as "the right disposition of things, arranged so as to lead to a convenient end". Through this notion of government, Foucault argued that the object of government is no longer confined by territorial borders and subjected only to its inhabitants as initially characterized in Machiavelli's elaboration of the power of a prince. On the contrary, Foucault (1991a) asserted that what government has to be concerned with is "men [sic] in their relations, their links, their imbrication with those other things which are wealth, resources, means of subsistence, the territory with its specific qualities, climate, irrigation, fertility, etc..." (p. 93). To this list we could add forest carbon, in which the core challenge is to manage the relationships between humans and forests.

In the previous chapter I introduced REDD+ as the latest type of governmental mechanism directed at human - forest relationships. It is inspired by the popular notion that market mechanisms are effective in solving global environmental problems (Mcafee and Shapiro, 2010; Osborne, 2011; Corbera, 2012; Fletcher and Breitling, 2012; McElwee, 2012). Critical geography scholars are concerned such 
approaches for neoliberal nature, involving processes of commodification, reregulation, privatization and re-territorialization are aimed at altering human behavior and shaping how people see and value the environment (Mcafee and Shapiro, 2010; Osborne, 2011; Büscher et al., 2012; Büscher and Fletcher, 2015).

However, as the previous chapter has warned, the neoliberalization of nature is a contested concept in geography (Ferguson, 2010; Yates and Bakker, 2014; de Freitas, Marston and Bakker, 2015). Diverse scholarly attempts have been made to establish a link between studies of the neoliberalization of nature and empirical REDD+ policies and implementation (McElwee, 2012; Milne and Adams, 2012; Astuti and McGregor, 2015; McGregor, Eilenberg and Coutinho, 2015). These empirical studies argue that market-oriented mechanisms to protect nature, such as Payment for Environmental Services (PES) and REDD+, do not always follow the general characteristics associated with the neoliberal theses in which accumulation by dispossession and the capitalisation of nature become the main rationality of government, reducing the state to a minimal role. REDD+ is more complex than that - having shifted from a monofunctional perspective that centrally focuses on sequestering carbon into a web of multifunctional and multi-actor perspectives that involve Indigenous issues, biodiversity protection, livelihood improvement, and forest governance reform (as will be discussed in Chapter 5, see also (Thompson, Baruah and Carr, 2011; Mahanty, Suich and Tacconi, 2013; Sunderlin et al., 2014; Atela et al., 2015).

In this thesis I investigate these shifting governmental narratives, rationalities and technologies that are accompanying this change in forest governance through the lens of governmentality. REDD+ economies require new ways of seeing and valuing the forests which are being mainstreamed through governmental technologies and rationalities (Bäckstrand and Lövbrand, 2006; Gupta et al., 2012; McGregor et al., 2015). The concepts and approaches from governmentality provide useful tools to examine these processes and understand how everyday encounters of power are reshaping our most banal desires and dreams of co-existing with forests (Rutherford, 2007). Governmentality facilitates the examination of how the production and circulation of particular discourses and practices shape and mould 
our understanding of the forest as part of the socio-natural world we live in (Rutherford, 2007; Winkel, 2012). As such it can inform neoliberal/not-quiteneoliberal debates regarding human - forest interactions.

This chapter expands on the concept of governmentality introduced in Chapter 1 as the main theoretical framework for the thesis. I start with the examination of the three types of power that Michel Foucault discussed in his various lectures: sovereignty, disciplinary and biopower, before leading a discussion of power as the art of government or the "conduct of conduct" (Foucault, 1991a). The chapter then discusses the production of neoliberal subjectivities. It follows with a section on discourse analysis as a means of studying governmentality. The subsequent section presents an analytical framework for analysing REDD+ government employing governmentality theory by observing: 1) governmental rationales, 2) technologies of government, 3) the production of knowledge, 4) the construction of new subjectivities, and 5) the process of rendering technical (Dean, 2009). The chapter then outlines some critiques and limits of governmentality as a theory and approach. The chapter is completed with a conclusion that discusses REDD+ as a form of government - aimed at governing human - forest relationships. Throughout the chapter examples are drawn from environmental governance with the goal of showing how certain governmental rationalities, discourses and subjectivities have become normalized and accepted as "truths" in governing human - environment relationships.

\subsection{Three types of power: Sovereignty, Disciplinary and Biopower}

Foucault developed the concept of governmentality as a critique of the traditional understandings of power that saw it as a possession that was held by the sovereign who implemented practices of coercion and discipline to achieve their goals (Dean, 2009). Foucault's conception of power is probably his biggest contribution to the scholarly discourse on governance (Rutherford, 2007). To understand Foucault's conception of power and governmentality, I will examine the genealogy of power out 
of which the notion of the art of government grew (Dean, 2009; Walters, 2012). Therefore, in the section below I outline three types of power that together form what Foucault called “the art of government” or governmentality (Foucault, 1991a).

\subsubsection{Sovereign Power}

Through his lecture in Society Must Be Defended, Foucault (2003) linked sovereign power with disciplinary and biopower. Foucault (1991a) argued that sovereign power co-exists other newer expressions of power within governance:

We need to see things not in terms of the replacement of a society of sovereignty by a disciplinary society and the subsequent replacement of a disciplinary society by a society of government; in reality one has a triangle, sovereignty-discipline-governmentality, which has as its primary target the population and as its essential mechanism the apparatuses of security (p.102).

Foucault (1990, p. 136) defined sovereignty as the power that comes from "the right to take life and let live" (p.136). In the context of modern state governance, Foucault extended his definition of sovereignty as the state's power that comes from its juridical domains to govern a particular population in a particular geographical territory. To link this concept of state's juridical power with governmentality, Foucault (2009) explained that:

The sovereign is no longer someone who exercises his power over a territory on the basis of a geographical localization of his political sovereignty. The sovereign deals with a nature, or rather with the perpetual conjunction, the perpetual intrication of a geographical, climatic, and physical milieu with the human species insofar as it has a body and a soul, a physical and a moral existence (p. 38).

Through this notion of "perpetual conjunction" between humans and things, Foucault (2009) showed how the state's main objective in practicing its sovereignty 
is to secure governable spaces within which it seeks to achieve the correct disposition of populations. The state's main strategy in attaining this specific aim is by employing laws as tactics, through which law acts as the expression of state's authority (Foucault, 1991a).

Fortress conservation is an excellent example of how sovereign power operates in the context of environmental governance (Fletcher, 2010; Kelly, 2015). The conservation park is an enclosed space with clear demarcated boundaries - they differentiate the type of governance for those that belong to the inside of the boundaries and those that don't (Kelly, 2015). The conservation officers work to police the demarcation, subjecting those who go inside the park to specific rules and codes of conducts. Often these are the forest dependent communities who live in and around the park perimeter, and who suddenly found themselves being governed by the park's regulations, and punished through imprisonment and fines for breaches (Fletcher, 2010). In Indonesia, the MOF through the Park Management Office as the state apparatus enacts fences and fines mechanism through diverse laws and regulations to criminalize those who illegally enter the Park (Fletcher, 2010; Arsel and Büscher, 2012; Kelman, 2013). The laws control the type of human - forest relationships allowed (Agrawal, 2005; Fletcher, 2010).

\subsubsection{Disciplinary Power}

Foucault (1979) discussed disciplinary power in his lecture Discipline and Punish through the elaboration of prison as an enclosed space productive of docile bodies. The prison works through surveillance technologies to render visible all the inmates' activities in order to supervise and control their behaviour at all times (Foucault, 1979). Bentham's Panopticon is analysed as a technology of surveillance aimed at disciplining and shaping all the bodies inside the prison's walls through the normalization of particular conducts while forbidding other ways of being (Foucault, 1979). Foucault (1979) extended his analysis on the concept of disciplinary power through the examination of the military, the clinic and the school. These disciplinary institutions work through the micro-physics of power that is aimed at internalizing particular norms and values. 
Disciplinary power has the characteristic of both totalizing and individualizing the governed (Foucault, 1979). An example of this is the way the school disciplines both its entire student body and each student. The teachers take care of all of the students as a total object of government. However, the school also individualizes, as the teachers know each of the students and work through their particular needs and objectives. This implies the specific knowledge the teachers have about each of the students.

In the context of REDD+ governance, the use of carbon standards attempts to discipline REDD+ proponents (Lövbrand and Stripple, 2011; Gupta et al., 2012; Boer, 2013; McGregor et al., 2015). The Climate, Community and Biodiversity Alliance (CCBA), for example, is a platform which provides a standard for voluntary REDD+ implementation at the site level (see http://www.climate-standards.org/). The Climate Community and Biodiversity (CCB) standard requires REDD+ project proponents to adopt standardized mechanisms of designing and implementing the project aimed at minimizing negative social and environmental impacts. The standard disciplines and governs the proponent's conduct in managing the REDD+ project through the verification and validation processes in which the proponent's compliance is analysed and measured (Gupta et al., 2012). The failure to comply with the standard will result in a failure to attain CCB verification and label. The labels, which have to be combined with a carbon accounting standard, are key for the proponent's ability to obtain quantified emissions reductions certificates (CERs) - which is the only commodity in a REDD+ project that can be traded in the carbon market (see http://www.climate-standards.org/). In this way standards discipline project developers to act in particular ways.

Sovereign power is often coupled with disciplinary power in order to generate proconservation subjectivities (Agrawal, 2005; Fletcher, 2010). In community based conservation management, researchers have shown how park management often employs groups of watchmen that involve community members to police the park boundaries (Mayaka, 2002; Poppe, 2012). Fiscal incentives are employed to attract the communities' involvement in implementing surveillance technologies and 
reporting encroachment activities (Spiteri and Nepal, 2008; Thapa Karki, 2013). These imply the implementation of surveillance technologies are not just by those in authority, but also through more intimate monitoring by community members themselves. In this way communities come to self-govern their behaviour in order to avoid the risks of being criminalized. Foucault (Foucault, 1991a) reminded us, however, that in the implementation of sovereign and disciplinary powers the governed subjects still have agency. Forest communities often behave outside of the conducts being normalized by governing actors - a type of action that Foucault termed as "counter conduct", that is attempts brought by the governed subjects in order to create different forms of being (Gordon, 1991).

\subsubsection{Biopower}

Foucault (1990) developed the notion of biopower in his work The History of Sexuality, Vol. 1 through his elaboration on the concept of the governance of the population. Foucault used the term biopower to explain the concept of power as the art of government where "wealth, longevity, health etc." of the population are the main aims of governing practices. In his lecture Security, Territory and Population delivered in College de France on 11 January 1978, Foucault (2009) defined biopower as:

The set of mechanisms through which the basic biological features of the human species became the object of a political strategy, of a general strategy of power, or, in other words, how, starting from the eighteenth century, modern Western societies took on board the fundamental biological fact that human beings are a species (p. 1).

Foucault discussed the notion of population to elaborate a different conception of the art of government. In biopower, population is no longer defined as people confined in a particular territory and subject to the state's sovereign power to administer life. Population as the object of governance in biopower is defined in relation with health, disease and other matters essential for the well being of society (Dean, 2009). The government of the population is based on the knowledge 
produced through statistical measurements, such as the census and demography and has underpinned the growth of a number of social science disciplines (N. Rose, 1999a). However, populations are not simply passive groups of living beings subject to the government's will; instead populations possess knowledge and agency that play a big role in enabling the process of government (Dean, 2009).

Rabinow (1984, p. 17) asserts that biopower "brought life and its mechanisms into the realm of explicit calculations and made knowledge-power an agent of the transformation of human life". Biopower's focus on human life has lead to studies of human society and the use of censuses, demography and statistics to govern life. However increased awareness of the importance of the environment to human life has led to an interest in biopower and non-human life, or the government of human/non-human relations. For Foucauldian scholars to understand the governance of human and nature relationships, one needs to study how discourses about the environment are being produced, circulated, and employed to form particular political truths about the nature (Rutherford, 2007). Darier (1999) explores this through the concept of ecopolitics - the implementation of biopower in the governance of the nature/environment.

An example of ecopolitics is the use of scientific forestry in shaping the politics of forest governance (Baldwin, 2003, 2013; Cepek, 2011). Originating from Germany, scientific forestry is a field of knowledge that is taught to foresters so they are able to intensify the forest's capacity in producing forest commodities - particularly timber (Hölzl, 2010). Science in forestry management is a tool that is often employed by the state and the private sector in constructing the tropical forest as a wild frontier with plentiful resources such as timber and minerals that are ready for exploitation. Siscawati (2012) traces the colonial scientific forestry applied by the Dutch Government on the islands of Java and Madura, in Indonesia, to manage and intensify teak forests. Classification of land and trees as well as the production of maps became the Dutch government's main tools for subjecting forests to scientific scrutiny (Peluso and Vandergeest, 2001; Vandergeest and Peluso, 2006). Scientific forestry facilitates the establishment of quantifiable and measurable plans in designing and managing the forests as economic resources. Post-independence, 
Indonesian academic foresters have developed a forest management system through the implementation of technologies such as timber felling methods, tree regeneration techniques and silviculture system that are seen as modern and effective (Siscawati, 2012). These scientific approaches enable the state to perform what Rose and Miller (1992) call "government at a distance" - a process of governing many locales through inscribed forms of activities and conditions designating what is or isn't appropriate - which consequently allows the authorities to execute government from afar (Curtis, 1995). The state often employs scientific

forestry to denigrate swidden culture - a practice of Indigenous agriculture based on the method of shifting cultivation - as ineffective, harmful and backward (Cramb et al., 2009; Fox et al., 2009; Dressler, 2014). Many studies have found that state's implementation of scientific forestry - with its maps, rationalities and statistics - has been employed as the main narrative to assert control over forest land and used to legitimize land appropriation from Indigenous communities (Peluso, 1995; Peluso and Vandergeest, 2001).

\subsubsection{Summarising Power}

Through the discussion of these three types of power, we can see that power is not something that can only be owned by the state or the king. Power is embedded in the knowledge, the action, the practices, and the relations between humans and things (Dean, 2009). The art of government involves the triad of powers described above. To conclude this section, following Rutherford (2007) I outline four characteristics of power, understood as the art of government, that will facilitate the subsequent discussion on governmentality. These characteristics defy the traditional conception of power as something that is merely oppressive and hegemonic:

Power is defined as 'actions on others' actions': that is, it presupposes rather than annuls their capacity as agents; it acts upon, and through, an open set of practical and ethical possibilities. Hence, although power is an omnipresent dimension in human relations, power in a society is never a fixed and closed regime, but rather an endless and open strategic game (Gordon, 1991, p. 3). 
Foucault (1990) outlines four main characteristics of power. First, he argues that power is not in the hands of the sovereign, instead, power is everywhere and exercised through many practices, discourses, agents, and institutions (Rutherford, 2007, p. 296). Foucault (1990) stressed that power is not only exercised from above, but instead also comes from below. As such, it can be said that the exercise of power produces webs of diverse power relations. Power is capillary and diffuse. Consequently, he opposed the notion of a binary power that segregates the leader and the follower (Rutherford, 2007, p. 296). Rather than seeing power as exclusively exercised by state apparatuses, Foucault foresaw power as a thing embedded in the relational actions of the population. Thus, for Foucault (2001) "to govern in this sense, is to structure the possible field of actions of others" (p. 221).

Second, Foucault (1990) argued that the practices of the modern art of government (governmentality) do not replace practices of state's sovereign, biopower and disciplinary practices, rather to govern effectively each of these types of power acts as a precondition of the others (Dillon, 1995; Dean, 2009). The art of government, as becomes apparent in this context, is essentially concerned with the art of exercising, arranging and combining different types of power "so as to lead to a convenient end" (Foucault, 1991a, p. 93). Thus, power is not necessarily oppressive but can also be productive. Foucault (2001) further argued that the art of government requires the concepts of freedom and agency within subjects of governance. He explained that:

Power is only exercised on "free subjects" and only insofar as they are "free" - understanding by this claim individual or collective subjects faced with a field of possibility in which several conducts, several reactions, and various modes of behavior can take place (Foucault, 2001, p. 342).

The conception of freedom and agency in the practices of power bring our attention to the third characteristic of power - resistance. Foucault (1990) stated that where there is power, there is resistance. However, Foucault highlighted that resistance cannot be seen as the outside part of power, but instead as one of its components that seeks to transform and reshape power to be conducted differently. He called 
this resistance "counter conduct" (Foucault, 2009, p. 202), that is an attempt to resist the established conduct and a struggle to create different practices of conducting conduct (Foucault, 2009).

The last characteristic of power is "intentional but non-subjective" (Rutherford, 2007, p. 296). He argued that while there are purposes behind the exercise of power, these objectives cannot be associated with the wishes of particular people, but rather with the discursive dynamic of society, which often results in a diverse array of unpredictable consequences, effects and outcomes (Foucault, 1990). Indeed Foucault specifically said that the exercise of power "implies a plurality of specific aims" rather than one dogmatic goal (Foucault, 1991b, p. 95). Understanding these four characteristics of power is important for Foucault's interlocutors to employ his conception of governmentality. The subsequent section endeavors to explain governmentality, the main theoretical framework employed in this thesis.

\subsection{Governmentality}

Citing Guillaume de la Perriere, Foucault (1991a) defined governmentality as "the conduct of conduct". It operates through calculated means and rational activity by "educating desires and configuring habits, aspirations and beliefs" of individuals and groups (Li, 2007a, p. 279). Thinking through a governmentality lens allows us to see that governance's main aim is to shape human conduct, and its target is to produce "the welfare of the population, the improvement of its condition, the increase of its wealth, longevity, health et cetera" (Foucault, 1991a, p. 100). In order to achieve its aim, a governmental intervention employs a variety of techniques and certain forms of knowledge. Dean (2009, p. 25) argues that governmentality is a representation of "collective mentalities" created through "the bodies of knowledge, belief and opinion" in which our individual minds and consciousnesses are immersed. In a broad sense, Foucault (1991a, p. 102) summarized governmentality as:

The ensemble formed by the institutions, procedures, analyses, and reflections, the calculations and tactics that allow the exercise of this very specific albeit complex form of power, which has population as its target, and 
apparatuses of security [or calculative technologies employed] as its essential mechanism and political economy as its form of knowledge (emphasis added).

Drawing on this definition to apprehend REDD+ governmentality means seeing REDD+ as an art of government that works through the development of new calculated strategies, practices and institutions, aimed to promote and sustain particular discourses and practices amongst forest stakeholders. This assemblage of government (or a set of discursive and material strategies and mechanisms) aims to shape human conduct and educate people to protect forest carbon and associated “ecosystem services” (McGregor et al., 2015).

In the context of REDD+, governmentality theory provides an innovative means of analysing both traditional state and non-state actors' attempts to influence, define and reshape REDD+ policies and programmes (Rutherford, 2007; Winkel, 2012; McGregor et al., 2015). Governmentality recognises that governmental interventions are undertaken not only by the state apparatuses but also by non-state actors, including but not limited to NGOs, scientists, researchers, bankers, and the private sector - anyone who is involved in attempts to shape the conduct of the population (Li, 2007a, 2007d; Dean, 2009). The concept of governmentality provides insights into how assemblages of practices, agents, knowledge and techniques work to produce governable subjects (Hart, 2004). To employ governmentality in analysis is to explore regimes of government that try to shape human conduct by examining how and the conditions under which we are governed and through which we govern ourselves and others (Dean, 2009). In the following section I focus on how these concepts have been used to analyse environmental issues.

\subsection{Green Governmentality}

Environmental problems similar to 'madness', 'sexuality' and 'criminality' are not 'out there' in a pure and unmediated form, but various techniques, procedures and practices construct and produce these fields in such a way that they become both objects for knowledge and targets for regulation 
(Bäckstrand, 2004, p. 703 cited in Rutherford 2007; Rutherford, 2007)

As an art of government, governmentality disposes us toward the understanding of forests in particular ways and produces calculated technologies in ways that enable that disposition (Rutherford, 2007). Green governmentality is a term coined by Luke (1999) to define the government of multifaceted relationships between people and environment. Green governmentality focuses on the practices of power that inherent in politics, knowledges and practices, as well as everyday discourses, which actors attempt to mainstream in order to arrange "things" correctly (Luke, 1999; Rutherford, 2007). The "things" in this particular study are humans and non-humans relations, such as human relationships with forest, carbon, peatland and biodiversity. Green governmentality emphasises to the formation of new environmental subjectivities as the result of the mainstreaming of green practices and knowledges at different scales (Agrawal, 2005; Fletcher, 2010; Skoglund, 2014).

Green governmentality researchers are interested, for example, in how the environmental crisis is being represented and manufactured in the age of the carbon-constrained world, and how new interventions are invented as solutions (Oels, 2005; Bäckstrand and Lövbrand, 2006; Bulkeley and Newell, 2010). Another area of interest for green governmentality is how lands in far away places - in locations some explorers classified as new "untouched" resource frontiers - are subjected to statistical picturing (Demeritt, 2001). This refers to a set of processes to render them manageable and investable for extensive agriculture, a phenomenon critiqued as a land rush (Li, 2014c) or land grab (Borras et al., 2012; Fairhead, Leach and Scoones, 2012; McCarthy, Vel and Afiff, 2012). In short, green governmentality focuses on attempts to create regimes of environmental governance in which people govern themselves and others according to particular environmental rationalities and objectives (Rutherford, 2007).

A similar concept developed by Agrawal (2005) is environmentality. He uses the term to explain the making of new environmental subjectivities in his study of the people of Kumaon in India. He defines 'environmentality' as "the knowledges, politics, institutions, and subjectivities that come to be linked together with the 
emergence of the environment as a domain that requires regulation and protection" (Agrawal, 2005, p. 226). Agrawal (2005) highlights how the Forest Department used particular forms of scientific forestry knowledge to render visible the objects of governance, such as a forest classification system, accounting, and reporting mechanisms. These webs of practices and knowledges are employed by the Forest Department in fostering the adoption of pro-conservation subjectivities among community members (Agrawal, 2005).

Fletcher (2010) uses the concept of environmentality in analysing the governance of forest conservation. He outlines four types of environmentalities - neoliberal, disciplinary, sovereign, and truth in his examination of the strategies being used to regulate human - environment interactions. Fletcher (2010) defines neoliberal environmentality as governance through market rationales and the use of incentive/disincentive technologies in fostering peoples to get involved in conservation practices. Disciplinary environmentality refers to the governance of subjects through the internalization of particular pro-conservation norms and values. Disciplinary approaches aim to produce docile subjects who will act according to shared values and ethics that are considered to be in the best interests of the society (Dean, 2009). Sovereign environmentalities are pursued through regulations and laws that will be effective in "forcing" populations to behave accordingly - the fences and fines approach of fortress conservation for example. A final environmentality is exercised based on 'particular conception of the nature and the order of the universe' derived from forest communities. For example beliefs in a non-material relationship between humans and nature is common in some Indigenous societies and used to claim authority over behavior or encourage particular subjectivities (Fletcher, 2010, p. 178). These environmentalities work dynamically and reciprocally by intersecting, complementing, or even negating each other within particular contexts (Li, 2007c). They are pursued through a variety of techniques and forms of knowledge to achieve their aims (Dean, 2009). 


\subsection{Neoliberal governmentality and the formation of new subjectivities}

Dean (2009) elaborates on the formation of new subjectivities through what he has called the "technologies of agency". These technologies aim to sustain how subjects perform through a series of training or capacity building activities to improve their skills. Cruikshank (1999) addresses these enhancement techniques as "technologies of citizenship". These are multiple forms of self-enhancement techniques that are designed to systematically prevent citizen's dependency on the state (Cruikshank, 1999). Dean (2009) warns Foucauldian interlocutors, however, that,

The manipulation of [a] population's agency doesn't mean to cancel out agency but seeks to show how it is produced, how it is inserted into a system of purpose, and how it might overrun the limits established for it by a particular programme or even the strategic purpose of a regime of government" (p. 196).

He further explains that these technologies of agency will often be employed to particular targeted populations that according to the state's standard are classified as being in high risk or incapable of governing themselves (Dean, 2009).

An example in the context of Indonesia's forest governance is the state's "schemes to divide citizenship" (Li, 2014a). The state often classifies Indigenous peoples and forest dependent communities as populations that endure high risks of falling into the trap of backwardness characterised by "poor" living standards and inability to effectively manage resources (Li, 2014a). Thus, legitimised by this rationale, state and non-state actors often implement racialised governmental policies intended to "improve" the life of these "backward" peoples and govern their relation with the land and resources they depend upon (Li, 2007c). Such populations are understood to be part of society that have no interest in making financial profit, inability to manage risks and on the brink of losing their knowledge about living harmoniously with nature (Li, 2014a). For the state, this understanding of Indigenous peoples motivates them to appropriate their lands and lease them to parties that are deemed 
to have the capacity to maximize profits and manage risks (Peluso, 1995; Peluso and Vandergeest, 2001; Fay and Sirait, 2005). On the other hand, non state actors such as NGOs have been trying to fix tribal peoples through various interventions that are aimed at restoring more "authentic" ways of living ( $\mathrm{Li}, 2000)$. As a target of government, these forest people are not passive; they express their agencies by deciding to embody particular subjectivities that will enable them to secure particular goals - often related to land and livelihoods.

Technologies of agency are closely related to other techniques of subject formation in neoliberal government, referred to as "technologies of performance". Dean (2009) defines technologies of performance as techniques of subjectification through which citizens' conduct is shaped in order to generate effective, accountable and "calculating individuals" within "calculable spaces" subject to particular "calculative regimes" (p. 197). The establishment of both technologies of agency and technologies of performance enable what Miller and Rose (1990; 1992) termed "government at a distance".

In governance based on carbon rationality, this government at a distance is facilitated by the standardization of carbon monitoring, reporting and verification or carbon accountability. Gupta et al (2012) propose the notion of carbon accountability to "denote both how forest carbon is accounted for in REDD+ and the need to hold to account those who are doing so" through calculative practices (p. 726). This practice of carbon accounting is aimed at achieving public trust, rendering carbon accountable and visible as well as fungible for the purpose of global trading (Gupta et al., 2012; Boer, 2013; McGregor et al., 2015). Gupta et al (2012) point to the possible benefit of this accountability mechanism for more than just forest governance by arguing that while carbon accountability is a practice of homogenization this also provides means to hold REDD+ managers accountable to forest dependent communities and Indigenous peoples.

As a technology of governance, carbon accounting paves a new way of seeing and connecting forest and human relationships (Boer, 2013; Astuti and McGregor, 2015). New types of responsibility are introduced wherein the private sector has an 
opportunity to directly contribute to conserving forest carbon through a (dis)incentive based mechanism. In introducing this responsibility, the state entrenches the responsibility for mitigating climate risks "into the domain for which the individual [or collective] is responsible and transforming it into a problem of "self-care" (Lemke, 2002, p. 59). The underlying basis of neoliberal rationality is located in the incentive technologies through which responsible individuals are motivated to be economically-rational subjects whose acts and behavior can be modeled on cost-benefit analysis. In her research on neoliberal governmental technologies, Cruikshank (1999) elaborates what she has called the "self-esteem" movement. The movement's objective is to build "a new politics and a new social order" through the governing of ourselves according to neoliberal rationalities (Lemke, 2002, p. 60). Lemke argues that the new order is not going to transform the status quo imbued by "capitalism, racism, the patriarchy etc..." but rather will focus on the empowerment of individuals to be able to continuously govern, measure, and judge themselves against a set of social norms (Lemke, 2002, p. 60).

\subsection{Discourse, Knowledge and Power}

Dean (2009) does not propose a practical methodology on how to undertake governmentality analysis, however Feindt and Oels (2005) suggest that governmentality scholars employ discourse analysis. Through his interest in the study of human behaviour, Foucault developed a scholarly approach to discourse and its role in conducting populations. Foucault defined discourse as a set of rules which, at a given period and for a given society, delineate the regimes of truth (Winkel, 2012). According to Foucault, truth is something contextual and relative, subject to constant economic and political stimulation (Feindt and Oels, 2005; Winkel, 2012). Discourse is strongly related to governmentality, as discourse allows some things to become normalised and seen as commonsense, it also legitimises the authority of particular organisations (Bäckstrand and Lövbrand, 2006). Aside from being capable of rendering visible the relation between power and knowledge, discourse analysis also takes into account the notion of agency, through concepts such as discourse coalition and knowledge broker (Hajer, 1995). 
Lees (2004) differentiates between two streams of discourse analysis: first is the analysis rooted in the Marxist thinking that seeks to untangle the articulation of hegemony and the work of ideology, and the second one is the Foucauldian analysis that focuses on unravelling the practices that gave birth to particular truth and how these practices could (and could not) engender new subjectivities. Rutherford (2008) argues that the goal of this latter stream of analysis is not to determine which discourses are wrong or right, but rather to identify how these discourses operate and come to be known as truth and its associated impacts. I follow Rutherford's in approaching discourse analysis as a methodology to understand the way particular truths on forest and climate change are formed and implemented.

Hajer (1995) proposes three key terms in discourse analysis to study governmentality. First, the metaphor is highlighted by Hajer (1995) as the way to express one kind of thing in terms of another in which both the messenger and the recipient will share the same understanding on the thing discussed. Second is story line, defined as "a condensed form of narrative in which metaphors are used" (Hajer, 2005, p. 301). Third is discourse coalition described by Hajer (2005) as "a group of actors that, in the context of an identifiable set of practices, shares the usage of a particular set of story lines over a particular period of time" (p. 302). Through the analysis of narratives, which contain story lines, metaphors, and other forms of discursive construction and institutionalization, governmentality scholars can observe distinct features of REDD+ as a regime of government, explore the nature of the coalitions that have formed, and the dominant narratives and absent voices in the struggle over REDD+ ideas and concepts.

In shaping the policy making process and its content, actors engage in discursive practices by arguing and negotiating causes that reflect their interests and beliefs (Benford and Snow, 2000; Bulkeley, 2000). Hajer (1995) argues that discourse occupies a significant role in the policy making processes. It renders legible particular policy problems while obscuring others, it consequently also empowers and signifies certain solutions as the right choices while obfuscates other alternatives (Hajer and Versteeg, 2005). As a policy subject, there are multiple discourses on REDD+, and particular REDD+ actors may form coalitions with other 
actors whose discursive stance is similar to them. Brockhaus et al (2014) argue that discourse coalitions are a key component of REDD+ politics. According to them, the stronger the coalition building that takes form, the better the chance for the allied actors to shape REDD+ policy making and negotiation processes (Brockhaus, Di Gregorio and Mardiah, 2014).

\subsection{Analyzing REDD+ Governmentality}

How then does one study REDD+ governmentality? Dean (2009, p. 40) points the need for scholars to think of governmentality not as an "expression of a particular principles, as reducible to a particular set of relations, or as referring to a single set of problems and functions" but instead as consisting of different practices and discursive logics. As an art of government, governmentality entails not only regimes of materials and discursive elements but is also characterized by fluid and unstable process. In this section I outline some of the tools that governmentality scholars have used when analysing the art of government and drawn upon these tools to analyse the three case studies of this research.

McKee (2009) proposes two interrelated approaches to study governmentality: analysis of the discursive field and examination of the actual interventionist practices through ethnographic inquiries. The latter approach goes beyond the traditional text-based discourse analysis by undertaking empirical ethnography to reveal how the "conduct of conduct" is implemented, contested, and challenged, as well as to disclose their unintended consequences and effects (Hart, 2004; Li, 2007c; Mckee, 2009). In doing so, this approach offers detailed analysis of "the exercise of power in situ that is sensitive to both time and place", and captures tensions, conflicts and multiple struggles between various actors and agencies (Mckee, 2009).

According to Li (2007a) governmentality inquiries into the regime of government combines:

The analysis of governmental interventions (their genealogy, their diagnoses and prescriptions, their boundaries and exclusions) with analysis of what 
happens when attempts to achieve the "right disposition of things" encounter -and produce- a "witches brew" of processes and practices that exceed their scope (p. 279).

Scholars in this area focusing their analysis of governmental intervention through the discursive examination of programmes (Oels, 2005; Li, 2007a; Dean, 2009). In Foucauldian terminology, programmes are the rationality of government, that is "a way or system of thinking about the nature of the practice of government, capable of making some form of that activity thinkable and practicable both to its practitioners and to those upon whom it is practised" (Gordon, 1991, p. 3).

Following Foucault, Li considers programmes as "fragments of reality" because programmes form into institutions, they inform individual behaviour, and generate a series of effects ( $\mathrm{Li}, 2007 \mathrm{a}, \mathrm{p} .28$ ). Therefore, programmes help describe many otherwise unobservable practises, processes, and events. An ethnography of government, according to Li (2007a) will analyse how programmes shape and reshape things, while also considering how programmes are compromised and changed to accommodate failure and contestation. Rose (1999b) argues that the domain to be governed must be rendered technical to create a governmental programme. This is what Dean termed "fields of visibility", in which truth is constructed and made visible via a "grid of intelligibility" (Dean, 2009, p. 41). For example, how in a REDD+ project forest is mapped and zoned renders the forestcarbon viewable and understandable while restricting alternative understandings such as Indigenous cosmologies (see Chapter Five for further discussion on this process). For Dean (2009), the first step or dimension in analysing governance mechanisms from a governmentality perspective is to unravel this field of visibility.

The second dimension is the analysis of the technical tools of government or what Dean called as the techne or technologies of government. In the same vein, Li (2007a, p. 279) termed this technical aspect practices or "an arena of intervention" that functions as the technical rendition of programmes. Scholars analyzing the techne of government will assess the "means, mechanisms, procedures, instruments, tactics, techniques, technologies, and vocabularies" that are used by agencies to govern 
human conduct (Dean, 2009, p. 41). In the context of REDD+, an example of the techne of government is the implementation of the Free Prior Informed Consent Protocol (FPIC). The protocol is an instrument that governs how forest dependent communities and REDD+ managers engage with the REDD+ project (Li, 2014a). Li (2007a, p. 279) suggests another important set of practices that should be given attention: "informal practices of compromise and accommodation, everyday resistance or outright refusal".

The third dimension of analysing governmentality is the episteme of government or the concern around the form of knowledge that is constituted from, and enables, the practice of governing (Dean, 2009, p. 42). Consequently, governmentality analysis will look at how certain regimes of truth are constructed that define how we perceive reality (Oels, 2005). For example, how discourses on ecological modernization enables particular "truths" to be asserted which then become incontestable beliefs to be acted upon. In REDD+, the 'truth' is that market mechanisms provide incentives that will incite particular "good" behavior and increase new technology that will solve ecological crises (Mcafee and Shapiro, 2010; Osborne, 2011; Milne and Adams, 2012). The analysis of the episteme of government is closely linked to the analysis of the techne of government. Therefore, governmentality scholars will observe how particular constructed "truths" employ assemblages of technologies, agencies and institutions to operate on and maintain that truth (Dean, 2009).

As an example the high level attention devoted to global environmental threats such as climate change and biodiversity extinction - has motivated discussion on ecological knowledge and its role in contributing to the implementation of new governmental technologies in governing the environment (Biermann, 2007; Biermann et al., 2009, 2012). The discourse on "green economy" serves as an example of how the construction of truth about the world's unsustainable development, together with environmental economics as a new form of knowledge and field of expertise, has legitimised the invention of new domains of governance and interventions (Cook and Smith, 2012). This new domain is the production of space for non-state actors in contributing to global efforts to save the planet while 
profiting through the commodification of ecosystem services (Jenkins, Scherr and Inbar, 2004; Vignola et al., 2009; Farley and Costanza, 2010). Ecosystem services as a new "boom commodity" has transformed the practices and technologies of forests and biodiversity governance (Vignola et al., 2009). The key to the survival of the planet is seen as being located in the production of new global supply chains based on nature's services - rendering invisible alternative understandings, that could instead emphasise reform of the mode of developed countries' production and consumption behaviour (Bumpus and Liverman, 2008).

The last element in analyzing governmentality programmes pays attention to the formation of new identities and subjects (Agrawal, 2005; Dean, 2009; Cepek, 2011). To study this final component, scholars ask "what forms of person, self, and identity are presupposed by different practices of government and what sorts of transformation do these practices seek?" (Dean, 2009, p. 43). In the context of REDD+, the proliferation of reformist subjectivities in the green movement is an example of the formation of new subjects. The reformists differentiate themselves from the radical by believing that in order to solve ecological crises, one needs to employ market mechanisms and that civil society has to "complement state-centric practices" through critical engagement (Bäckstrand and Lövbrand, 2006, p. 56). Radical subjectivities are also reified, where there is a refusal to believe the viability of market mechanisms in solving environmental crises that caused by the capitalist economies themselves - instead favouring changes in the pattern of consumption and production as a more equitable approach (Bäckstrand and Lövbrand, 2006).

Dean's governmentality framework discussed in the previous paragraphs is the mean of analysis employed in the first case study on the REDD+ Taskforce. I draw on the notion of techne or governmental technology to apprehend the techniques, means and procedures that are created by the Taskforce to normalize REDD+ in Indonesia. In addition, the concept of subjectivity in Dean's governmentality framework enables the identification of new pro-REDD+ subjects formed as a result of the mainstreaming of REDD+ as a new mechanism of governing human - forest relations. The understanding of different types of governmentalities: sovereign, disciplinary and neoliberal governmentality also informs the process of examining 
the REDD+ Taskforce (see Chapter 5). For case study 2 on OMI, I extend Dean's governmentality framework with Rose's notion on rendering technical and process of "problematization" (N. Rose, 1999b; Li, 2007c; Dean, 2009). According to Li (2007c), these are two common sets of practices experts adopt to seek to dispose things - human and non human in "the right manner" (Foucault, 1991b, p. 95). According to Dean (2009), problematization is a process of identifying defects that need to be fixed. Problems are framed in particular ways to enable "certain sorts of diagnoses, prescriptions, and techniques" (Li, 2007c, p. 7) to be proposed as solutions. Effective government requires that these solutions are achievable and non-political - thereby seen as being in the interests of all (Li, 2007c). This requires empowering particular authoritative but apolitical knowledges and approaches - a practice known as rendering technical (N. Rose, 1999a; Li, 2007c).

James Scott argues that states deliberately generate simplified forms of selected data that will facilitate the effective governance of populations rather than factually representing society (Scott, 1998). By combining selected data with diverse governmental technologies, the state is able to depict the reality they represent as a universal truth, and hence outline apolitical and appropriate solutions (Scott, 1998). Li (2005) extends Scott's argument by acknowledging the need to look beyond state simplification to analyse the complexities hidden behind state governance initiatives. By examining the messy assemblages informing state approaches we can generate "something new - new ways of seeing oneself and others, new problems to be addressed, new modes of calculation and evaluation, new knowledge, and new powers" (Li, 2005, p. 389).

The identification of problems and construction of solutions exemplify "expertise and constitutes the boundary between those who are positioned as trustees, with the capacity to diagnose deficiencies in others, and those who are subject to expert direction" (Li, 2007c, p. 7). Li warns of the tendency of the trustees to render the domain to be governed as non-political as an attempt to take out political-economic concerns and reposing them using the "neutral language of science" (Li, 2007c, p. 7). Such attempts privilege those with access to scientific and technical knowledge and marginalise those that don't. Li (2007c) explains further that the process of 
rendering technical will always be accompanied with practices of confrontation. As I will discuss in case study 2 (see Chapter 6), practices of confrontation has been the case in Indonesia where the introduction of $\mathrm{OMI}$ as a technical means to resolve long standing political economic conflicts has engendered oppositional actions amongst some Indigenous and environmental activists who actively contest and disrupt policy making processes. However, overt and radical moves opposing OMI are rare, instead contestation takes the form of "subtle slippages and subversions" (Stratford, 2002 , p. 2) oriented at centralizing principles of socio-ecological and Indigenous justice within the new technical framework.

Governmentality theories assist us in understanding broad practices of forest governance, but are less relevant in appreciating how a particular practice, such as Indigenous claims-making, emerges in a particular context. Li (2007b) argues that this gap can be filled by adopting an assemblage approach. By combining governmentality and assemblage approaches I aim to develop a comprehensive theoretical framework for case study 3 that will look at how Indigenous territories and associated forms of technological ordering are emerging in the context of REDD+. Assemblages describe the gathering of diverse elements, incorporating more-than-human relationships, and disjointed practices into coherent temporal formations that make particular propositions or forms of government possible (DeLanda, 2006; Li, 2007b; Anderson and McFarlane, 2011; McCann, 2011).

As a term, assemblage emphasises emergence, provisional unity, dispersion and multiplicity (Anderson and McFarlane, 2011). French philosophers, Deleuze and Guattari developed the concept of assemblage "to highlight the way in which material content (bodies, actions, passions) and enunciations/articulation (statements, plans, laws) are linked not in linear fashion but rhizomatically as reciprocal presuppositions and mutual insertions play themselves out" (Deleuze and Guattari, 1987, pp. 85 - 91 cited in Li, 2007b). This depiction of assemblages as rather chaotic and sprawling collection of linkages between socio-material elements is useful in connecting the complexities of the new political conjuncture with placebased Indigenous land struggles. Governmentality focuses attention on human agency, while assemblages remind us of the agency of non-human actors, in the 
production of territory (Anderson and McFarlane, 2011; Bear, 2013). Following Li (2007b, p. 264) I focus on the practice of assembling, that is "the hard work required to draw heterogeneous elements together, forge connection between them and sustain these connections in the face of tension", rather than approaching assemblage as a final and complete product of actions.

Assemblages are characterised by processes of territorialisation (Bear, 2013). In the context of assembling Indigenous land claims, territorialisation is a process of defining spatial boundaries, be it through implementation of policy, formation of social identity, or arrangement of jurisdictional and administrative borders (Peluso, 1995). Territorialisation can also signify exclusion and omission through processes of intensifying homogeneity within an assemblage, such as the process through which a particular community comes to declare itself as a specific Indigenous entity (Li, 2000; Afiff and Lowe, 2007). Governmentality researchers are interested in how spaces and territories are created and governed and can themselves becomes technologies of government (Sanchez, 2003). Most research on this theme has explored spatial dimensions of governmentality in terms of the escalating use of physical and sociospatial ordering in urban lifestyle (Merry, 2001; Robins, 2002; Sanchez, 2003). Spatial ordering is the production of "space within which movements and flows are regulated in ways which enable authorities to act; a space that is measured, directed and standardized" (Barry, Osborne and Rose, 1996, p. 127). Hannah (2000) points out that spatial ordering is not only repressive power but is also an empowering means for people to govern themselves.

Taking into account the theoretical discussion so far, Figure 2.1 below summarizes the theoretical framework and literature that are drawn upon to approach each of the three case studies. The understanding of governmentality both as a modality of power and as an analytical framework lays the foundation for the thesis' core conceptual framework. McKee's (2009) proposal to approach governmentality study by analysing both the discursive field and actual material practices are adopted to study REDD+ in Indonesia. 


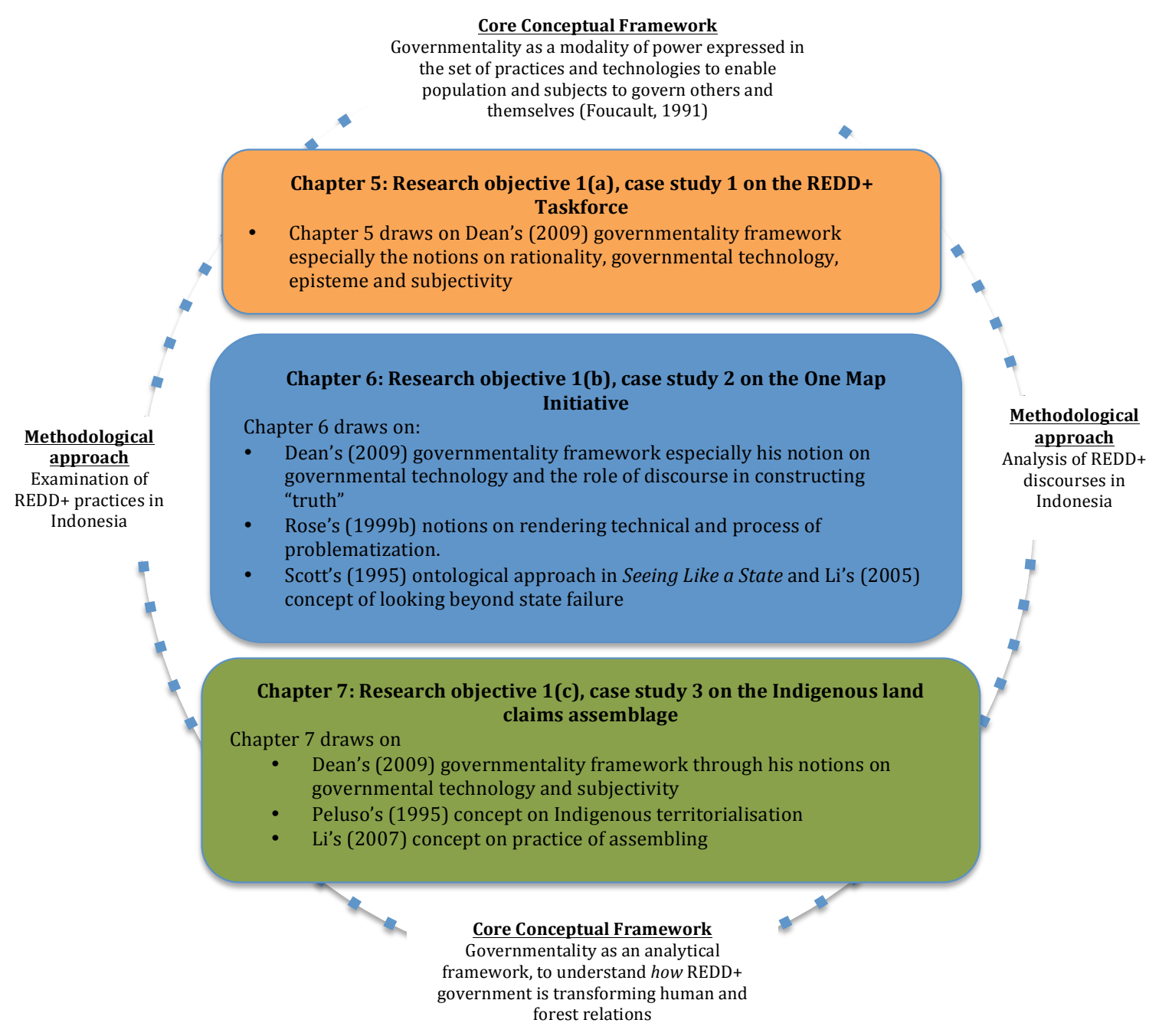

Figure 2.1 Theoretical framework of the research

\subsection{Critiques and Limits of Governmentality}

O'Malley and Clifford (1997) highlight the tendency of Foucauldian interlocutors to limit their governmentality studies to discursive analysis of governmental rationalities and policies. This tendency has ignored the diverse possible outcomes when governmental approaches are being implemented upon targeted populations. Thus, they demand govermentality scholars go beyond discursive text of policies by investigating how governmental practices are being executed and contested. McKee (2009) asserts that when a researcher ethnographically inquires into the implementation of governmental approaches, they have to take into account the insitu socio-political context where they are being implemented. By taking into 
account this particular condition and context, researchers can highlight the importance of place and time to the operation of power and governance.

The second common critique to governmentality study is the inclination of its scholars to focus on the state as their object of investigation. Li (2007c) argues that governmental practices especially those of neoliberal governmentality work through multiple dominions that go beyond the confinement of the state. Rutherford (2007) similarly endeavours to influence green governmentality scholars to pay attention to the role on non-state actors, such as NGOs, community based organisations, and the private sector in mainstreaming new conduct and engender new green subjectivities. She also warns scholars to be aware of the nature of governmentality as an incomplete project, always contested, synchronized, and subject to an endless revitalization of approaches and rationalities (Rutherford, 2007). Indeed Foucault (2001) pointed to the characteristic of power, understood as an art of government, as an infinite strategic game of "permanent provocation" by saying that;

At the very heart of the power relationship, and constantly provoking it, are the recalcitrance of the will and the intransigence of freedom. Rather than speaking of an essential freedom, it would be better to speak of an 'agonism' of a relationship which is at the same time reciprocal incitation and struggle; less of a face-to-face confrontation which paralyzes both sides than a permanent provocation (pp. 221 - 222)

For example, Li's (2007c) work analyses the MOF's and The Nature Conservancy's (TNC) efforts to shape community subjectivities in areas affected by the establishment of Lore Lindu National Park in the hilly interior of North Sulawesi Province, Indonesia. TNC, a major player in conservation circles, had worked through various approaches to engendering environmental subjectivities in local communities. One of the projects was sponsored by Asian Development Bank (ADB) and was implemented through a set of calculated practices intended to achieve an 'integrated conservation and development project'. In her study, Li shows how the project of subject formation is contested by its targeted population. Communities grew unhappy with the TNC's approach in managing the project and refused to 
adopt the 'conservation subjectivities' despite various disciplinary and incentive mechanisms applied. Thus, Li's analysis contributes to the understanding on governmentality as an unfinished project subject to political provocation and contestation by targeted populations.

In proposing the notion of 'governmentality's limits', Li (2007c) points to the feature of governmentality as:

Being irreducibly utopian, governmental interventions can never achieve all they seek. An important reason promised improvements are not delivered is that the diagnosis is incomplete ... it cannot be complete if key politicaleconomic processes are excluded from the bounded, knowable, technical domain. Furthermore, governmental interventions produce effects that are contradictory, even perverse.

Li (2007c) addresses three key factors that bound and challenge the implementation of governmental approaches, these are: politics, population, and knowledge. Politics refers to "the ever-present possibility that a governmental intervention will be challenged by critics rejecting its diagnoses and prescriptions" (Li, 2007c, p. 17). Similarly populations "are not passive objects ... they are ... actants, dynamic forces that constantly surprise those who would harness and control them ... [thus] men in their relations with things "cannot be reconfigured according to plan" (Li, 2007c, p.17). Knowledge failings in rendering intelligible society's complex socio political reality places a further limit on governmental strategies (Li, 2007c). Reflecting on these limits, governmentality research needs to be conducted with the awareness of its messy actuality.

\subsection{Conclusion}

This chapter has described Foucault's genealogical conception of power and what constitutes governmentality analysis. The chapter began by outlining epistemological characteristics of power in relation to the art of government. This discussion drew on Foucault's discussion of three forms of power - sovereign, 
disciplinary and biopower. The discussion then moved on to explain how to employ governmentality as a lens for observing the practice of REDD+ government. I specifically followed Dean's (1999) framework in focusing on four aspects of analysis: the rationality of government, the techne, the episteme, and the formation of new subjectivities as illustrated in Figure 2.1. I have drawn on this analytical framework in my research analysis and present it's results in Chapters 5, 6, and 7. The next chapter discusses the methodology of this research and specifically highlights the qualitative methods that I used in collecting fieldwork data and apprehending the messy actualities of REDD+ implementation. The next chapter also introduces scholar activism as the positionality that I chose to embody as an attempt to reflect a more hopeful inquiry and engaged scholarship. 


\section{Navigating Hopeful and Critical Geography Research}

"To be truly radical is to make hope possible, rather than despair convincing" (Raymond Williams, Sources of Hope, 1989)

\subsection{Introduction}

The previous chapter sought to introduce governmentality as the main theoretical concept and framework underpinning this research. Through understanding power as an immanent element in everyday relations, the chapter discussed the role of governmental technologies, knowledge production and the construction of new subjectivities in governing human and forest relationships (Li, 2007c; Winkel, 2012). The current chapter develops this post-structuralist account and discusses the ethos and values that inspire the research. This chapter is divided into five sections. The first section discusses the epistemological approach through the notions of scholar activism and "hopeful" geographic research. The second section lays out the multisited and multi-scalar critical inquiry method employed to collect fieldwork data. The third section describes the analytical and writing methods used in a creative attempt to assemble bits and fragments of material and theoretical data into a comprehensible argument (Crang, 2003). The fourth section reflects on my positionality as a scholar activist and some challenges that I encountered in adopting this subjectivity. The fifth section briefly discusses the limitations of the methods. The chapter is then finalized with a conclusion.

\subsection{A Slippery Attempt to Undertake Critical yet Hopeful Geographical Research}

In embarking on a research journey, a scholar usually aims to produce research that will be beneficial and useful for people or things. However, how does one 
characterize useful research? For whom should research be useful? And how does one suppose to undertake useful and critical research? These kinds of questions always emerge during the phase of designing a piece of research that aims to go beyond producing knowledge and a mere exercise in scholarship. In answering these queries, I draw from literature on scholar activism and follow the Autonomous Geographies Collective's (2010) definition of scholar activism as an activity that seeks to align one's academic work with political ideas: "to further social change and work directly with marginal groups or those [engaged] in struggle" (p. 246). Derickson and Routledge (2015) define scholar activist as a person who engages with "theoretical and conceptual questions in ways that are always insistently and dialectically rooted in the struggles of everyday life" (p. 2). The adoption of positionality as scholar activists is usually driven by the scholars' deep emotional responses to the social and ecological injustices and inequalities and the desire that motivate them to politically engage in social struggles (Derickson and Routledge, 2015).

In adopting positionality as a scholar activist, I have found it useful to examine the work of geographers Gibson-Graham $(2005,2006,2008)$ who emphasize the notion of hopeful geographies and Routledge \& Derickson's (2015) concept regarding the politics of resourcefulness. The work of these geographers have guided this research and informed the ethos of my personal attempt to undertake hopeful and critical geography research. Routledge and Derickson (2015) identify three ways of practicing the politics of resourcefulness. The first way is to commit to advancing the work of our collaborators through the resources that academics are often granted through their position. Examples of this are specific expertise related with writing and research, technological innovation and time management, and access to donors. The second way is to design research that examines questions and addressing concerns that are also in the interest of our collaborators. The third way is to design research that addresses the challenges that our collaborators face in their struggle to pursue progressive changes and identify conditions that will sustain their social movements. In conducting this research I practiced the first and the third ways of performing the politics of resourcefulness, as I will discuss further in the section below on researcher's positionality. 
Gibson-Graham are known as scholars who actively advocate the need for academic research to go beyond criticism and to start thinking about alternatives and hope (Gibson-Graham, 2005, 2006, 2008). This is difficult in the sometimes tense REDD+ research environment in which a multitude of discourses regarding neoliberal natures circulate, including the not-quite-neoliberal approach discussed in Chapter 1. However De Freitas, Marston and Bakker (2015) remind scholars to recognize the dynamism and tension that shape the particularity of neoliberal nature in a different contexts. This dynamism and tension can possibly be utilized by actors, such as activists, to serve their interests (de Freitas, Marston and Bakker, 2015). I am interested in responding to Gibson-Graham's call for hopeful research by, in addition to critically exploring the uneven effects of REDD+ neoliberal rationalities, to also focusing on how the neoliberal agenda in REDD+ can be resisted and repurposed.

Following Gibson-Graham's (2008) suggestion, I have navigated the research to adopt a "weak form of theory". Accordingly, I see the practice of using theory, as not being about forecasting failure and validating impossibility, but instead it is about seeing possibility and opportunity. According to Gibson-Graham (2008, p. 621), practicing weak theory can open new perspectives in seeing power as "a differentiated landscape of force, constraint, energy, and freedom" that is useful in producing political possibilities. In performing weak theory in a piece of REDD+ research, I resist the urge to jump into a premature judgement by labelling every REDD-related activity as the extension of capitalist interests. I perform what GibsonGraham (2008) define as "a reparative motive that welcomes surprise, tolerates coexistence, and cares for the new" (p. 619). Following Robbins' (2011) advice, I undertook this research as an attempt to go beyond merely describing a "hatchet" by also recognizing "seeds" in performing critical yet hopeful research. This is a practice Gibson-Graham eloquently state as being the need to read "for difference rather than dominance" (p. 623).

Performing a hopeful and critical geography research was not a straightforward task. It is a commitment that involves careful consideration of how one is involved in 
producing knowledge and struggling against injustice (Castree et al., 2010). Taylor (2014) suggests that a scholar activist's positionality is "performed, fluid and changing" (p. 307, see also Askins, 2009). Indeed, positionality is socially constructed and shifts according to the change in power relations (Gibson-Graham, 1994). In the section further below I will reflect on performing the positionality of a scholar activist and discuss the multiple challenges that I encountered both during the fieldwork and when I was completing research analysis and writing. In the subsequent section I will discuss the research method employed in this study and detailing the data collection method as well as the three case studies that underpinned this critical inquiry.

\subsection{Multi-sited and Multi-Scalar Critical Inquiry: Following "Beyond Carbon, More than Forest"}

REDD+ consists of a multitude of governmental technologies, actors, interests, and institutions. The cross-scalar process of REDD+ implementation can only be rendered intelligible by studying the network of programs and policies rather than the isolated node of a particular project. Drawing on an increasingly influential study on global policy, Peck and Theodore (2012) argue that researchers do not need to abandon ethnography methods in a globalising world but re-think what type of ethnography is suitable for unraveling fast moving policy. In the field of geography, this tradition started through the study of trans-local and cross scalar movements of policy and technologies using a multi-sited ethnographic method. Multi-sited ethnography is a concept coined by Marcus (1995) to better capture the relations of flows, links, places, and processes that shape a certain event in a particular place. It is a response to the challenge of conducting ethnography in the contemporary world where everything is connected and space is a product of social construction rather than merely particular geographical location.

Drawing on the same concern of understanding how globalization has affected local politics, Tsing (2005) proposes the ethnography of global connection, which is a method built to understand "spatially far flung collaborations and interconnections" 
and to recognize "awkward engagements" (p. ix). Through her fieldwork on forest politics in Indonesia, Tsing (2005) shows how the extent of forest destruction in South Kalimantan is not an expression of isolated political conjuncture, but a result of assembly of connections, frictions and encounters. To apprehend these chains of engagements, Tsing (2005) goes back and forth between examining the specific locales of her study and tracing along the diverse scales and chain of events, policies and peoples that have connections with her study sites. In so doing, Tsing (2005, p. ix) demonstrates that a story about socio nature in a village in South Kalimantan is simultaneously also:

A story of North American investment practices and the stock market, Brazilian rubber tappers' forest advocacy and United Nations environmental funding, international mountaineering and adventure sports, and democractic politics and the overthrow of the Suharto regime.

Reflecting on Tsing's ethnography concept of global connection, we come to understand that a multi-scalar ethnography is as important as a multi-sited one. Therefore, in this research, I follow the concept initiated by Xiang (2013) to complement a multi-sited ethnography with a multi-scalar perspective. The multiscalar perspective helps in organizing fieldwork and provides a means of analysis to apprehend the relations of things across scales. In thinking through multi-scale ethnography, I found Xiang's two scale classifications useful to understand how REDD+ shapes and is being conversely shaped by the existing forest politics. These two scale systems are: taxonomical scales (Delaney and Leitner, 1997) and emergent scales. Reading REDD+ through taxonomical scales could be interpreted into the conventional hierarchical systems that divide scales of REDD+ jurisdictional arenas into global, national, sub-national and project scales. Understanding the flows and links of REDD+ policies, rationalities and calculations among these hierarchical scales is important to understand why REDD+ governmental techniques work in certain scales while not in others.

Seeing REDD+ only through taxonomical scales is of course problematic. Similar to the notion of space, scale as a geographical concept is also socially constructed and 
relational. In seeing the concept of scales through post-structuralist accounts, one can argue that what matters is how scales can be rendered legible and thus "made into reality". This is where the second type of scale - the emergent, can be employed in seeing the complex intersection between knowledge and power in the REDD+ governmental system. Xiang (2013) notes that taxonomical and emergent scales intersect with each other, and through the exploration of these intersections, an ethnographic method can "study up" to interrogate centres of power (Nader, 1972), "study down" to examine everyday interactions, and most importantly "study through" (Reinhold, 1994, pp. 477 - 479; cited in Shore and Wright, 1997) to "trace ways in which power creates webs and relations between actors, institutions, and discourses across time and space" (Xiang, 2013, p. 14).

Taking into account the notions of multi scalar and multi sited ethnography from Marcus (1995), Tsing (2005), and Xiang (2013), I created a method of critical inquiry that is relevant for this qualitative research. REDD+ is constituted by a multitude of materials that are discursive, metaphorical, and spatial, expressed on a range of scales. Multi sited and multi scalar ethnographic methods provide appropriate strategies to apprehend REDD+ as an assemblage of governmental systems. Marcus (1995) warns, however, that multi-sited ethnography should not be seen as an attempt to represent the whole system of the studied object, but rather that the capacity of a researcher to engage with different scales and sites is what makes the multi-sited ethnography an interesting method. Given governmentality is the main theoretical framework in this study, and so it focuses on exploring the modes of thought in governmental practices, I followed Marcus' suggestion to "follow the metaphor" in applying multi-sited ethnogaphy. This method also aligns with Hajer's (1995) suggestion in using discourse analysis by examining metaphor to study governmentality (see Chapter 2). According to Marcus, "following the metaphor" is employed "when the thing traced is within the realm of discourse and modes of thought, then the circulation of signs, symbols, and metaphors guides the design of ethnography" (Marcus, 1995, p. 92).

In undertaking a "follow the metaphor" method, I traced the circulation and translation of Indonesia's REDD+ rationales represented in the metaphor of "Beyond 
Carbon, More than Forest" into things such as governmental technologies, institutions, initiatives, and coalitions. This metaphor is the tagline of Indonesia's REDD+ program which has been used to politically show that, instead of solely focusing on carbon conservation and offset, REDD+ is broadly defined as a new mode of Indonesia's economic development, based on "green" growth rationalities. Using this method, I was able to strategically navigate my research to follow the circulation of the metaphor and establish representative case studies where the metaphor was influential. It brought me to three cross scalar sites of engagement: the REDD+ Taskforce, the One Map Initiative, and an Indigenous land claim assemblage in a community called the Bahanei, which I will discuss further in the next section.

Despite its many potentials, multi-sited ethnography is not immune to criticism. The most common critic is its lack of depth, a characteristic that is usually tackled in a "traditional" ethnographic approach (Falzon, 2009). However, Marcus (1995) argues that the "thick description" in multi-sited approach can be found in the comprehensive analysis of networks between sites of studies and cross scalar encounters that are located in diverse places rather than in an isolated place of fieldwork. However, in employing multi-sited critical inquiry, I did not attempt to simplify the binary between single and multi sited qualitative research. Instead, I tried to express the way I inhabited and co-produced a number of sites of engagement simultaneously.

\subsection{Three Sites of Engagement}

Following the metaphor of "Beyond Carbon, More than Forest", in the first case study I trace how the REDD+ Taskforce worked to normalize REDD+ rationalities in Indonesia through diverse governmental technologies. I investigated the translation of the "Beyond Carbon" rationality of REDD+ government into ten imperative programmes which include:

1) Moratorium monitoring and One Map Policy Implementation,

2) Forest licensing management,

3) Law enforcement, 
4) Support for Indigenous mapping,

5) Forest fire control and management,

6) Green village,

7) Green school,

8) Support for integrated spatial planning,

9) Conflict resolution road map, and

10) Strategic program for national park and conservation forests.

Two programmes were then selected as the case studies two and three in this doctoral thesis: the One Map Policy and Indigenous mapping. The selection of these two programmes was based on the consideration that they represent two of the most contested themes in Indonesia's REDD+ governance: land tenure and forestland governance. Studying One Map Policy and Indigenous Mapping has also provided opportunity to enter the multi-sited, multi-actor and multi-scalar arenas of REDD+ implementation. Each case study is developed in detail in the findings chapters that configure the core of this thesis (see Chapters 5, 6 and 7). Figure 3.1 below points the location of the case studies.

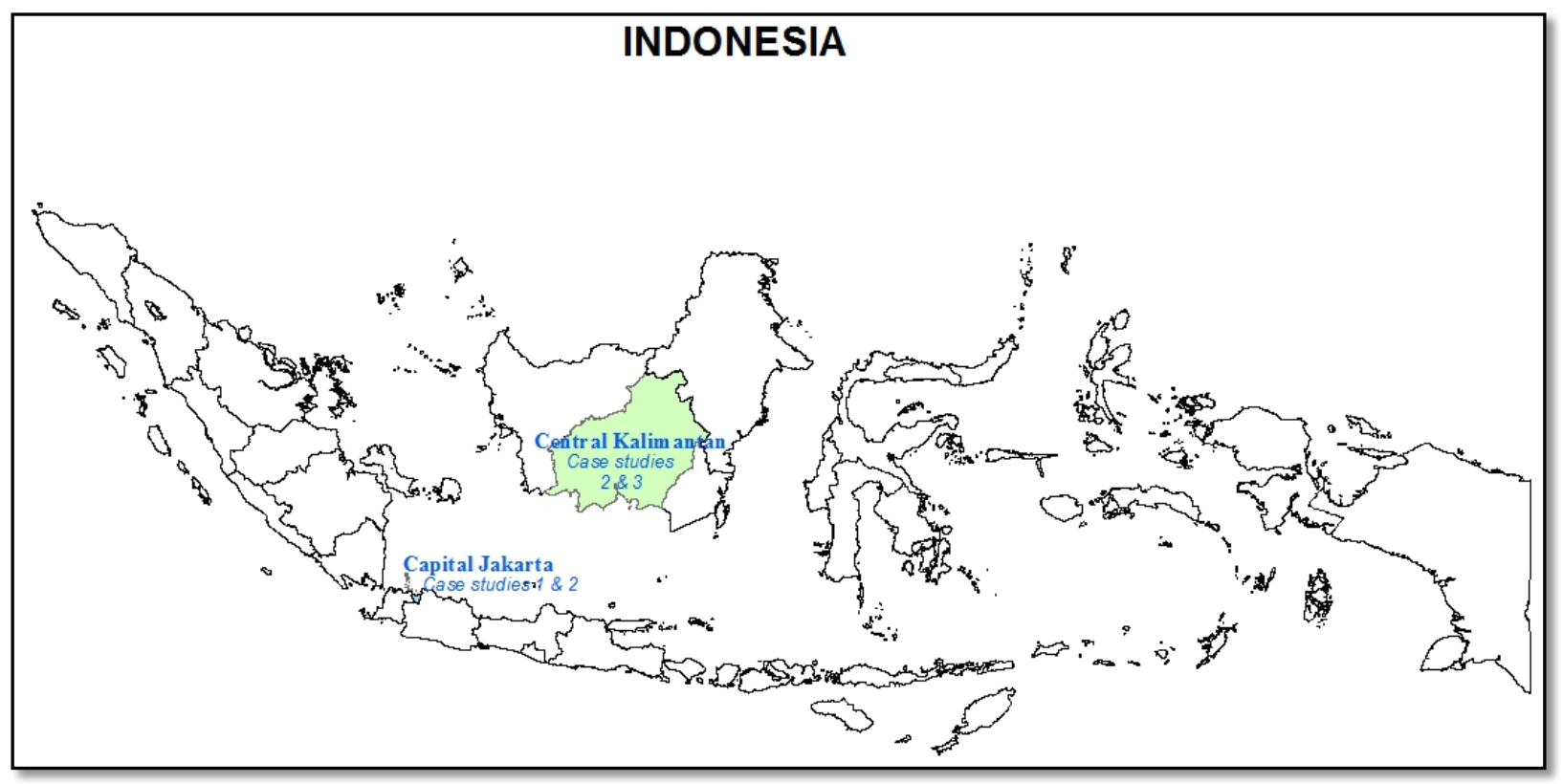

Figure 3.1 Locations of the case studies 


\subsubsection{Case Study 1: The REDD+ Taskforce}

The first site of engagement was the REDD+ Taskforce. Instead of a location or place, this site is a national institution that works in a cross-scale way in mainstreaming and normalizing REDD+ as a governmental system. The REDD+ Taskforce was a government owned ad-hoc agency formed to accelerate the development of infrastructure for REDD+'s full implementation (see Chapter 5 for a detailed elaboration). The REDD+ Taskforce was formed through Presidential Decree Number 19/2010 in September 2010 and mandated to carry out its tasks for ten months, which was eventually extended for another two years from July 2011 - June 2013

The Taskforce was replaced with the new REDD+ Agency that was designed to act as a more permanent institution responsible for the full implementation of REDD+. However, at the beginning of 2014, the Agency merged with the newly formed Ministry of Environment and Forestry (MOEF) under a newly elected political regime. In the rest of this thesis, I used the "REDD+ Taskforce" and "REDD+ Agency" both to refer to the Government of Indonesia's REDD+ institution. The use of the "Taskforce" mainly refers to the ad-hoc institution that worked from 2010 - 2013. Meanwhile, whenever the term "REDD+ Agency" is employed in the text, it refers to the agency that was formed in September 2013 to replace the Taskforce.

Having chosen the REDD+ Taskforce as a site of engagement, I studied the governmental strategies that the Taskforce implemented to mainstream both carbon and non-carbon rationalities into the governance of Indonesian forests. I collected the data through semi structured interviews and observations. A total of 54 interviews were conducted with both representation from the REDD+ Taskforce's staff and actors that were connected or were implicated in the work of the institution (see Table 3.1). Most of my informants, especially those classified as national actors, were being interviewed not only for the REDD+ Taskforce case study but also for two other case study sites. I started the fieldwork in May 2013 and arranged interview appointments with the Taskforce's working group members who included representation from government and ministerial agencies (MoF, 
Ministry of Environment (MOE), Ministry of Agriculture (MOA), the National Land Agency (NLA), Geospatial Information Agency (GIA), and UKP4 (see Appendix A for an extended explanation about each of this government body), NGOs (environmental NGOs and Indigenous based mass organisations) academics, and the private sector.

In addition to the Taskforce's working group members, the interviews were conducted with other institutions, such as research organizations, a palm oil plantation association, a logging companies association and a pulp and paper industry association. I also observed multiple workshops, seminars, and conferences on REDD+ and its related issues organized by different stakeholders (see Table 3.2). Aside from interviews and observation I relied on secondary data coming from the Taskforce and the REDD+ Agency's publications and reports. As I was working as a consultant for the Agency, I had the opportunity to read other consultants' and grantees' reports and minutes of meetings. Although I did not employ these internal data directly in my analysis, they shaped my overall understanding of how REDD+ unfolded in Indonesia as I will discuss further below in the section on positionality and reflection.

\subsubsection{Case Study 2: The One Map Initiative}

The second site of engagement was with a program called OMI. The Initiative is the government's attempt to fix the messiness of forestland governance where there is no clarity over who has rights to own and use Indonesia's forestland. The Initiative aimed to address the problem by producing a single common map of forestland in Indonesia that would serve as a reference in the decision making processes regarding spatial planning. OMI was overseen by UKP4 and the REDD+ Taskforce and has been implemented across agencies and scales. The Initiative became the means for the REDD+ proponents to problematize existing forest governance and to propose new governmental technologies.

In making the Initiative a site of engagement, I followed how new technologies of government were produced and contested, and their on-the-ground implementation. This approach enabled me to investigate how diverse ranges of 
actors responded to the new governmental technologies. Similar to case study 1 , I collected data through semi structured interviews with actors that were directly involved in the Initiative. I interviewed government officials, NGOs staff, Working Group members of the OMI, academics and the staff of research centres (see Table 3.1). In addition to 57 semi structured interviews, data was collected through observation (see Table 3.2). I joined multiple discussions and workshops on OMI and I visited Barito Selatan District in Central Kalimantan where the pilot for OMI activities was being rolled out. The visit was first conducted for three days in November 2013 during which time I joined a workshop organized by the Provincial Forestry Agency to discuss the forest gazettement process with five affected villages. The second and third visits were in March 2014 to interview local government agencies. Secondary data consisted of various reports and presentations provided by the REDD+ Agency.

\subsubsection{Case Study 3: The Indigenous Land Claim Assemblage in Bahanei}

The third site of engagement is an Indigenous mapping activity carried out by the Bahanei community, in Gunung Mas District, Central Kalimantan Province. The Indigenous mapping was conducted in order to establish the status of the land on which the Bahanei live as being Indigenous territory. Obtaining the status of Indigenous territory is a necessary strategy for a struggle against land appropriation by a logging company that has been given a forest concession by the MOF. The concession area overlaps with the Bahanei village and has caused tension between the villagers and the logging company. Together with other elements, the formation of a series of REDD+ policies and programs has produced a political conjuncture that is more open to Indigenous tenure rights. AMAN Central Kalimantan and the Bahanei utilized this new opening to gather political support and resources from REDD+ proponents in order to assemble a land claim.

The Bahanei was chosen as the third case study because it was the first Indigenous community that received support from the REDD+ Taskforce to carry out Indigenous mapping in Central Kalimantan as the first REDD+ pilot province. Similar 
to the two case studies above, the means for data collection included semi structured interviews, observation, and secondary data. The interviews were conducted with members of the REDD+ Taskforce staff, the AMAN National Secretary and AMAN CK staff, members of the Bahanei community, NGOs in Central Kalimantan, local government agencies in Gunung Mas District and government agencies at the Provincial level. In addition to a total of 55 interviews (see Table 3.1), I visited Bahanei in October 2013 which was then followed by my engagement in their advocacy activities, a positionality that I will elaborate further in the later section of this chapter.

\subsection{Discussion on Data Collection Methods}

\subsubsection{Semi Structured Interviews}

Semi-structured interviews were conducted to acquire the main data for this thesis. This method suits the need for research based on the co-production of knowledge (Whatmore, 2003). Semi-structured interviews provided an opportunity for the participants targeted by the research and I to form a two-way conversation that would potentially lead to rich materials that give attention not only to the researcher's need for valuable and "thick" empirical data but also to participants' concerns. This method also enabled me to quickly gain the trust of the informants. This trust is important so that the researcher is able to understand the role that each informant has and their perceptions of the REDD+ governmental assemblage. It is important to note that more than $50 \%$ of the participants had had some form of professional encounter with me as I used to work for several environmental NGOs before starting my doctoral study. In this case, most of the interviews went very well as it was easy to win their trust and the interviews were mostly conducted as a dialogue rather than a series of questions. Going through this dialogue facilitated an exchange of discursive and material knowledge, and felt less exploitative.

The interview participants were recruited with a "snow balling" method, where an interviewee would suggest other potential informants. This method has proven to be very effective as I could reach out to diverse participants and follow new leads. 
Sometimes, potential interviewees were recruited during a workshop or a conference, as it is easier to reach "elite" informants when they attend a seminar as resource persons. Interviews were conducted either in participants' offices, in cafes, or in their homes. In the case of recruiting informants during a workshop, the interviews were conducted during a break in the sessions. Each interview was carried out for around 60 to 90 minutes mostly in Bahasa Indonesia or English for foreign informants. In total 64 participants were interviewed, of which 23 participants were interviewed multiple times (see Table 3.1). Most of the informants provided insights into all three case studies, except for the community members whom I interviewed specifically in relation with the case study 3 on Indigenous mapping. In addition I immersed myself in REDD+ for a year and mixed with people at multiple conferences and workshops who informed my perspective, albeit informally. Similarly the list does it include members of the community that were present and contributed to the talks whenever I interviewed community representatives.

Table 3.1 List of interviewees

\begin{tabular}{|c|c|c|c|c|c|c|}
\hline \multirow[t]{2}{*}{ No } & \multirow{2}{*}{$\begin{array}{l}\text { Name } \\
\text { (pseudonym) }\end{array}$} & \multirow{2}{*}{$\begin{array}{l}\text { Position in REDD+ } \\
\text { Networks }\end{array}$} & \multicolumn{3}{|c|}{ Case Study } & \multirow[t]{2}{*}{ Date of interview } \\
\hline & & & 1 & 2 & 3 & \\
\hline 1 & Artodius & $\begin{array}{l}\text { Manager of REDD+ } \\
\text { Investor }\end{array}$ & $\checkmark$ & $\checkmark$ & & October 2013 \\
\hline 2 & Stefano & $\begin{array}{l}\text { Country representative } \\
\text { of an international } \\
\text { donor agency }\end{array}$ & $\checkmark$ & $\checkmark$ & $\checkmark$ & October 2013 \\
\hline 3 & Dormano & Head of local NGO & $\checkmark$ & $\checkmark$ & $\checkmark$ & October 2013 \\
\hline 4 & Nurmanto & $\begin{array}{l}\text { Program officer of a UN } \\
\text { Body }\end{array}$ & $\checkmark$ & $\checkmark$ & $\checkmark$ & October 2013 \\
\hline 5 & Hendarto & Academic & $\checkmark$ & $\checkmark$ & $\checkmark$ & October 2013 \\
\hline 6 & Rojiman & $\begin{array}{l}\text { Coordinator of a local } \\
\text { NGO }\end{array}$ & $\checkmark$ & $\checkmark$ & $\checkmark$ & October 2013 \\
\hline 7 & Maryanti & $\begin{array}{l}\text { Program officer of } \\
\text { REDD+ local office }\end{array}$ & $\checkmark$ & $\checkmark$ & $\sqrt{ }$ & October 2013 \\
\hline 8 & Bredana & Manager of a local NGO & $\checkmark$ & $\checkmark$ & $\checkmark$ & $\begin{array}{l}\text { October } 2013, \\
\text { November } 2013, \\
\text { January } 2015 \\
\end{array}$ \\
\hline 9 & Yandiman & Academic & $\checkmark$ & $\checkmark$ & $\checkmark$ & $\begin{array}{l}\text { May 2013, August } \\
2013\end{array}$ \\
\hline 10 & Cokorda & $\begin{array}{l}\text { Director of an } \\
\text { international }\end{array}$ & $\checkmark$ & $\checkmark$ & $\checkmark$ & May 2013 \\
\hline
\end{tabular}




\begin{tabular}{|c|c|c|c|c|c|c|}
\hline & & conservation NGO & & & & \\
\hline 11 & Mursidi & $\begin{array}{l}\text { Adviser to an } \\
\text { international financial } \\
\text { institution }\end{array}$ & $\checkmark$ & $\checkmark$ & $\checkmark$ & May 2013 \\
\hline 12 & Ovyana & $\begin{array}{l}\text { Program officer of an } \\
\text { international donor } \\
\text { agency }\end{array}$ & $\checkmark$ & $\checkmark$ & $\checkmark$ & May 2013 \\
\hline 13 & Wanmarda & REDD+ Investor & $\checkmark$ & $\checkmark$ & & $\begin{array}{l}\text { May 2013, July } \\
2013\end{array}$ \\
\hline 14 & Galungan & $\begin{array}{l}\text { Researcher in an } \\
\text { international research } \\
\text { centre }\end{array}$ & $\checkmark$ & $\checkmark$ & $\checkmark$ & May 2013 \\
\hline 15 & Kipeli & Staff in a national NGO & $\checkmark$ & $\checkmark$ & $\checkmark$ & May 2013 \\
\hline 16 & Nagara & $\begin{array}{l}\text { Director of a national } \\
\mathrm{NGO}\end{array}$ & $\checkmark$ & $\checkmark$ & $\checkmark$ & June 2013 \\
\hline 17 & Usman & $\begin{array}{l}\text { Program manager of a } \\
\text { UN body }\end{array}$ & $\checkmark$ & $\checkmark$ & $\checkmark$ & June $2013(2 x)$ \\
\hline 18 & Andika & $\begin{array}{l}\text { Staff of a government } \\
\text { ministry }\end{array}$ & $\checkmark$ & $\checkmark$ & & $\begin{array}{l}\text { June 2013, January } \\
2015\end{array}$ \\
\hline 19 & Jodi & $\begin{array}{l}\text { Member of the REDD+ } \\
\text { Taskforce's Working } \\
\text { group }\end{array}$ & $\checkmark$ & $\checkmark$ & $\checkmark$ & $\begin{array}{l}\text { June } 2013(2 x) \text {, } \\
\text { May } 2013\end{array}$ \\
\hline 20 & Ginting & $\begin{array}{l}\text { Executive Director of a } \\
\text { national NGO }\end{array}$ & $\checkmark$ & $\checkmark$ & $\checkmark$ & June 2013 \\
\hline 21 & Armando & Staff of a local NGO & & $\checkmark$ & $\checkmark$ & Juni 2013 \\
\hline 22 & Yamadhi & $\begin{array}{l}\text { Head of the REDD+ } \\
\text { Taskforce Working } \\
\text { group }\end{array}$ & $\checkmark$ & $\checkmark$ & & $\begin{array}{l}\text { Juni 2013, January } \\
2014 ; \text { January } \\
2015\end{array}$ \\
\hline 23 & Hartono & Staff of a national NGO & $\checkmark$ & & & $\begin{array}{l}\text { May 2013, Juni } \\
2013\end{array}$ \\
\hline 24 & Erwinda & $\begin{array}{l}\text { Staff of the REDD+ } \\
\text { Taskforce }\end{array}$ & $\checkmark$ & $\checkmark$ & $\checkmark$ & $\begin{array}{l}\text { Juni 2013, March } \\
2014\end{array}$ \\
\hline 25 & Josyana & $\begin{array}{l}\text { Staff of the REDD+ } \\
\text { Taskforce }\end{array}$ & $\checkmark$ & $\checkmark$ & $\checkmark$ & $\begin{array}{l}\text { Juni 2013, July } \\
2013, \text { September } \\
2013\end{array}$ \\
\hline 26 & Yunus & $\begin{array}{l}\text { Head of the Advocacy } \\
\text { division of a national } \\
\text { NGO }\end{array}$ & $\checkmark$ & $\checkmark$ & $\checkmark$ & July 2013 \\
\hline 27 & Afifah & Academic & $\checkmark$ & $\checkmark$ & $\checkmark$ & July 2013 \\
\hline 28 & Shinta & $\begin{array}{l}\text { Program coordinator of } \\
\text { a UN body }\end{array}$ & $\checkmark$ & $\checkmark$ & $\checkmark$ & July 2013 \\
\hline 29 & Yusliana & $\begin{array}{l}\text { Expert staff to a } \\
\text { government agency }\end{array}$ & $\checkmark$ & $\checkmark$ & $\checkmark$ & July $2013(2 x)$ \\
\hline 30 & Rukmina & Community member & & & $\checkmark$ & July 2013 \\
\hline 31 & Hartadi & Academic & $\checkmark$ & $\checkmark$ & $\checkmark$ & $\begin{array}{l}\text { July } 2013, \\
\text { February } 2014\end{array}$ \\
\hline 32 & Marina & $\begin{array}{l}\text { Director executive of a } \\
\text { national NGO }\end{array}$ & $\checkmark$ & $\checkmark$ & $\sqrt{ }$ & July 2013 \\
\hline 33 & Dewanti & $\begin{array}{l}\text { Program coordinator of } \\
\text { a national NGO }\end{array}$ & $\checkmark$ & $\checkmark$ & $\checkmark$ & July 2013 \\
\hline 34 & Yunanti & $\begin{array}{l}\text { Head of a division in a } \\
\text { government body }\end{array}$ & $\checkmark$ & $\checkmark$ & & July 2013 \\
\hline 35 & Hasan & Program manager of a & $\checkmark$ & $\checkmark$ & $\sqrt{ }$ & May 2013, July \\
\hline
\end{tabular}




\begin{tabular}{|c|c|c|c|c|c|c|}
\hline & & $\begin{array}{l}\text { national donor } \\
\text { institution }\end{array}$ & & & & 2013 \\
\hline 36 & Nurdina & Community member & & & $\checkmark$ & July 2013 \\
\hline 37 & Wandi & $\begin{array}{l}\text { Staff of a government } \\
\text { body }\end{array}$ & $\checkmark$ & $\checkmark$ & $\checkmark$ & $\begin{array}{l}\text { July } 2013(2 x), \\
\text { September } 2013\end{array}$ \\
\hline 38 & Taksaka & $\begin{array}{l}\text { Deputy Director to a } \\
\text { national NGO }\end{array}$ & $\checkmark$ & $\checkmark$ & $\checkmark$ & $\begin{array}{l}\text { July } 2013, \\
\text { December } 2014\end{array}$ \\
\hline 39 & Laura & $\begin{array}{l}\text { Senior researcher to an } \\
\text { international research } \\
\text { organization }\end{array}$ & $\checkmark$ & $\checkmark$ & & July 2013 \\
\hline 40 & Dhartono & REDD+ investor & & & & July $2013(3 x)$ \\
\hline 41 & Dandi & $\begin{array}{l}\text { Staff of a national } \\
\text { government agency }\end{array}$ & $\checkmark$ & $\checkmark$ & $\checkmark$ & July 2013 \\
\hline 42 & Kuswanto & $\begin{array}{l}\text { Deputy of a government } \\
\text { body }\end{array}$ & $\checkmark$ & $\checkmark$ & $\checkmark$ & $\begin{array}{l}\text { June } 2013, \\
\text { October } 2014, \\
\text { January } 2015 \\
\end{array}$ \\
\hline 43 & Nisa & $\begin{array}{l}\text { Communication officer } \\
\text { of a donor agency }\end{array}$ & $\checkmark$ & $\checkmark$ & $\checkmark$ & July 2013 \\
\hline 44 & Sumarjono & $\begin{array}{l}\text { Representation of a } \\
\text { logging industry } \\
\text { association }\end{array}$ & $\checkmark$ & $\checkmark$ & $\checkmark$ & July 2013 \\
\hline 45 & Randy & $\begin{array}{l}\text { Head of a division in a } \\
\text { government body }\end{array}$ & $\checkmark$ & $\checkmark$ & $\checkmark$ & $\begin{array}{l}\text { July } 2013, \\
\text { February } 2014\end{array}$ \\
\hline 46 & Nurwajono & $\begin{array}{l}\text { Director of a division in } \\
\text { a government body }\end{array}$ & & $\checkmark$ & $\checkmark$ & $\begin{array}{l}\text { July 2013, April } \\
2014\end{array}$ \\
\hline 47 & Suwardiyanto & $\begin{array}{l}\text { Head of a division in a } \\
\text { government body }\end{array}$ & & $\checkmark$ & $\checkmark$ & July 2013 \\
\hline 48 & Patrick & $\begin{array}{l}\text { Representation of an } \\
\text { international NGO }\end{array}$ & $\checkmark$ & $\checkmark$ & $\checkmark$ & July 2013 \\
\hline 49 & Rizaldi & $\begin{array}{l}\text { Representation of } \\
\text { Indonesian Chamber of } \\
\text { Comerce }\end{array}$ & $\checkmark$ & $\checkmark$ & & July 2013 \\
\hline 50 & Januarto & $\begin{array}{l}\text { Representation of palm } \\
\text { oil industry association }\end{array}$ & $\checkmark$ & $\checkmark$ & & July 2013 \\
\hline 51 & Mulyono & $\begin{array}{l}\text { Staff of a pulp and paper } \\
\text { industry }\end{array}$ & $\checkmark$ & $\checkmark$ & & July 2013 \\
\hline 52 & Aryo & Head of a local NGO & $\checkmark$ & $\checkmark$ & $\checkmark$ & October 2013 \\
\hline 53 & Hersri & Staff of a national NGO & $\checkmark$ & $\checkmark$ & $\checkmark$ & $\begin{array}{l}\text { September 2013, } \\
\text { October } 2013(2 \mathrm{x}) \text {, } \\
\text { December } 2014\end{array}$ \\
\hline 54 & Bonar & $\begin{array}{l}\text { Secretary General of a } \\
\text { national NGO }\end{array}$ & $\checkmark$ & $\checkmark$ & $\checkmark$ & October $2013(2 x)$ \\
\hline 55 & Trigunawan & District Secretary & & $\checkmark$ & $\checkmark$ & November 2013 \\
\hline 56 & Bapa Nandita & Community member & & & $\checkmark$ & $\begin{array}{l}\text { April 2013, } \\
\text { October } 2013(2 x)\end{array}$ \\
\hline 57 & Bapa Rara & Community member & & & $\checkmark$ & October 2013 \\
\hline 58 & Ojiyanto & Academic & $\checkmark$ & $\checkmark$ & $\checkmark$ & November 2013 \\
\hline 59 & Bapa Zuli & Community member & & & $\checkmark$ & $\begin{array}{l}\text { November 2013, } \\
\text { April } 2014\end{array}$ \\
\hline 60 & Bandana & $\begin{array}{l}\text { Head of REDD+ local } \\
\text { secretariat }\end{array}$ & $\checkmark$ & $\checkmark$ & $\checkmark$ & $\begin{array}{l}\text { June 2013, } \\
\text { November } 2013\end{array}$ \\
\hline 61 & $\begin{array}{l}\text { Bapa } \\
\text { Samadikun }\end{array}$ & Province Secretary & $\checkmark$ & $\checkmark$ & $\checkmark$ & November 2013 \\
\hline
\end{tabular}




\begin{tabular}{|c|c|c|c|c|c|c|}
\hline 62 & Yuwono & $\begin{array}{l}\text { Local forestry agency } \\
\text { official }\end{array}$ & $\checkmark$ & $\checkmark$ & $\checkmark$ & March 2014 \\
\hline 63 & Arnie & REDD+ investor & $\checkmark$ & $\checkmark$ & $\checkmark$ & December 2013 \\
\hline 64 & Poniman & $\begin{array}{l}\text { Local forestry agency } \\
\text { official }\end{array}$ & $\checkmark$ & $\checkmark$ & $\checkmark$ & $\begin{array}{l}\text { November 2013, } \\
\text { April } 2014\end{array}$ \\
\hline
\end{tabular}

I prepared a general guiding list of questions before each of the interviews to stimulate but not to direct the discussion. I approached each of the interviews with a different prompt sheet because each of the informants had their own specific expertise, experience and concern in relation to three of my case studies. I provided a consent sheet and a pager containing general information on the objectives of the research for all research participants for their references (see Appendix C). In presenting the interview results, I decided to use pseudonyms to create a degree of anonymity, due to the politically sensitive nature of this research topic. Although efforts have been made to keep the informants identity confidential, anyone close to the issues may be able to identify them through the informants' particular comments or positions. The interviews were, when possible, recorded and transcribed. Permissions were requested prior to it being recorded. Two transcribers who had signed confidentiality agreements assisted me in transcribing the interview records (see Appendix D).

The use of transcribers in aiding the transcription of interview records has been an interesting process that I can reflect on several ways. First, the two transcribers have saved hours of my limited time by doing the laborious works of transcribing around 85 hours of recording. It is important to note that not all of the interview records have been translated, only those interviews conducted in Bahasa Indonesia were transcribed by the two transcribers due to the language limitation. Meanwhile, I have been solely responsible to transcribed interviews that were conducted in English and Dayaknese. Secondly, the two transcribers that I have sought assistance from are fellow activists working for local NGOs and community based organisations that I wholeheartedly support. Working with local and community based organizations often means low to almost no routine salary. Committed to support other fellow activists I commissioned the tasks of transcribing the interviews in the hope to share my financial resources and temporarily sustain their livelihood, one of 
the expression in which I embody the politics of resourcefulness in doing research (Derickson and Routledge, 2015). Thirdly, hiring fellow activists rather than professional transcriber means comparatively low quality of work. This situation provided a significant challenge during which I found many errors in the transcripts. The nature of debates in REDD+ that contains scientific terminologies particular to carbon and economic knowledge, have added layer of complexity for the two transcribers to fully comprehend the interviews that they tried to transcribe. Therefore, I had to go back and forth between the recording and the transcripts to ensure that there were no errors in my data.

\subsubsection{Observation}

Participant observation enabled the collection of empirical data that would have been difficult to obtain from one on one interviews. In the case of this research, for instance, the interaction among different forest stakeholders, each with their own interests, can easily be rendered intelligible through observing a multistakeholder meeting. Participant observation has also facilitated the identification of silences and omissions, and who is being marginalized and prioritized in the REDD-related decision making or project policy implementations by showing what concerns are (not) being addressed in the meeting. Observation is one of the keys in the qualitative research method. In this research it has enabled the investigation of mundane forms of power, in which it is the aim of a governmentality study to critically inquire into how people are subjected to daily technologies of government that enabled them to govern themselves and others.

Observation data was collected in the form of field notes both from the various meetings and when I stayed with the Bahanei (see Table 3.2 for list of observed events). These field notes are a source of analysis for this thesis and informed the results chapters. Claiming a position as a scholar activist, I was never purely observing; I also asked questions, expressed opinions and sometimes had the role of facilitator for the discussion. These blurred boundaries served as scholar activism in action where I contributed to the advancement of social and environmental justice agendas. The multiple positionalities that I had during the field work made me 
oscillate between observer-as-participant and participant-as-observer. Thus I have never been entirely "inside" or "outside". I will further elaborate this multiple positionalities and reflect on how it has affected the research in the later section of this chapter. I will now discuss the methods I employed in data analysis and writing to make sense of the messy actualities of REDD+ material and discursive implementation in Indonesia.

Table 3.2 REDD+ events observed

\begin{tabular}{|c|c|c|c|}
\hline Organizer & $\begin{array}{l}\text { Theme of the } \\
\text { workshop/meeting }\end{array}$ & $\begin{array}{l}\text { Scope } / \text { Scale } \\
\text { of the } \\
\text { meeting }\end{array}$ & Date and Location \\
\hline REDD+ Taskforce & $\begin{array}{l}\text { Financial institution for } \\
\text { REDD+ implementation }\end{array}$ & National & Jakarta, May 2013 \\
\hline CIFOR & $\begin{array}{l}\text { National workshop on } \\
\text { REDD+ context, elements } \\
\text { and dynamic in } \\
\text { Indonesia }\end{array}$ & National & Jakarta, May 2013 \\
\hline REDD+ Taskforce & $\begin{array}{l}\text { Legal review and law } \\
\text { enforcement related } \\
\text { with forest crimes }\end{array}$ & National & Jakarta, May 2013 \\
\hline UNORCID & $\begin{array}{l}\text { REDD+ and Indigenous } \\
\text { rights recognition }\end{array}$ & National & Jakarta, May 2013 \\
\hline AMAN & Adat forest recognition & National & Jakarta, May 2013 \\
\hline $\begin{array}{l}\text { Clinton Climate } \\
\text { Initiative }\end{array}$ & Annual Partners meeting & National & Bogor, May 2013 \\
\hline $\begin{array}{l}\text { Participative } \\
\text { Mapping Network }\end{array}$ & $\begin{array}{l}\text { Participative mapping } \\
\text { and sustainable land use } \\
\text { planning }\end{array}$ & Local & Kapuas, June 2013 \\
\hline $\begin{array}{l}\text { Civil Society } \\
\text { Coalition for Saving } \\
\text { Indonesian Forest } \\
\text { and Global Climate }\end{array}$ & $\begin{array}{l}\text { REDD+, climate } \\
\text { mitigation in general and } \\
\text { the role of civil society } \\
\text { organizations }\end{array}$ & National & Jakarta, June 2013 \\
\hline $\begin{array}{l}\text { Geospatial } \\
\text { Information Agency }\end{array}$ & $\begin{array}{l}\text { The One Map Policy and } \\
\text { Participative Mapping } \\
\text { Standard }\end{array}$ & National & Jakarta, June 2013 \\
\hline UN-REDD & Gender and REDD+ & National & Jakarta, July 2013 \\
\hline
\end{tabular}




\begin{tabular}{|c|c|c|c|}
\hline $\begin{array}{l}\text { Programme } \\
\text { Indonesia }\end{array}$ & & & \\
\hline UN-REDD & $\begin{array}{l}\text { REDD+ global } \\
\text { partnership workshop }\end{array}$ & International & $\begin{array}{l}\text { Palangkaraya, } \\
\text { October } 2013\end{array}$ \\
\hline $\begin{array}{l}\text { Participative } \\
\text { Mapping Network } \\
\text { Central Kalimantan } \\
\text { Branch }\end{array}$ & $\begin{array}{l}\text { REDD+, safeguards and } \\
\text { FPIC implementation }\end{array}$ & Local & $\begin{array}{l}\text { Palangkaraya, } \\
\text { November } 2013\end{array}$ \\
\hline $\begin{array}{l}\text { AMAN Central } \\
\text { Kalimantan }\end{array}$ & $\begin{array}{l}\text { Indigenous mapping and } \\
\text { Indigenous tenure rights }\end{array}$ & Local & $\begin{array}{l}\text { Barito Selatan, } \\
\text { October } 2013\end{array}$ \\
\hline CIFOR & Forest Asia Summit & International & Jakarta, May 2014 \\
\hline $\begin{array}{l}\text { Central Kalimantan } \\
\text { Forestry Agency }\end{array}$ & $\begin{array}{l}\text { Forest gazettement } \\
\text { process and conflict } \\
\text { resolution }\end{array}$ & Local & $\begin{array}{l}\text { Barito Selatan, } \\
\text { November } 2013\end{array}$ \\
\hline $\begin{array}{l}\text { Clinton Climate } \\
\text { Initiative }\end{array}$ & Annual partners meeting & National & $\begin{array}{l}\text { Jakarta, December } \\
2013\end{array}$ \\
\hline $\begin{array}{l}\text { Kotawaringin Barat } \\
\text { Forestry Agency }\end{array}$ & Community forestry & Local & $\begin{array}{l}\text { Kotawaringin } \\
\text { Barat, September } \\
2013\end{array}$ \\
\hline REDD+ Agency & $\begin{array}{l}\text { National meeting with } \\
\text { REDD+ provinces }\end{array}$ & National & $\begin{array}{l}\text { Jakarta, March } \\
2014\end{array}$ \\
\hline $\begin{array}{l}\text { REDD+ Joint } \\
\text { Secretariat Central } \\
\text { Kalimantan }\end{array}$ & $\begin{array}{l}\text { Discussion on REDD+ } \\
\text { programs with REDD+ } \\
\text { districts }\end{array}$ & Local & $\begin{array}{l}\text { Palangkaraya, } \\
\text { April } 2014\end{array}$ \\
\hline $\begin{array}{l}\text { AMAN Central } \\
\text { Kalimantan }\end{array}$ & $\begin{array}{l}\text { Indigenous mapping and } \\
\text { its formal recognition }\end{array}$ & Local & $\begin{array}{l}\text { Gunungmas, April } \\
2014\end{array}$ \\
\hline REDD+ Agency & $\begin{array}{l}\text { National meeting with } \\
\text { REDD+ stakeholders }\end{array}$ & National & $\begin{array}{l}\text { Jakarta, December } \\
2013\end{array}$ \\
\hline
\end{tabular}

\subsection{Data analysis and writing}

In making sense of the fieldwork data, I follow Crang's (2003) suggestion who likens the analysing process to a creative practice of producing meaning and making order. Analysis is a task that requires a researcher to orchestrate, manipulate, and make connections in the fieldwork material. For me it involves a process of: going back and forth through the notes, translating and transcribing the materials, interpreting 
and connecting fragments of data, coding these notes systematically and following the evolution of thought while going through the fieldwork notes. Crang (2013, p. 130) argues that analysing and writing are an embedded process that cannot be separated, "it is thinking by writing that tends to reveal the flaws, the contradictions in our ideas, forcing us to look, to analyse in different ways and rethink".

One can argue that, in short, analysis is a process of teasing out bits or fragments from a set of data and recognising patterns that emerge in order to assemble an intelligible answer for a particular question. For post-structuralist research, one has to go beyond identifying patterns in the set of fieldwork data, and to start analysing why this particular pattern emerges and not another, how does one relate to that particular pattern, what other patterns are not represented in the fieldwork data, and so on. In the case of this research, the governmentality approach focuses the study on how a particular development initiative is being employed to create a world order governing humans use and relations to forests. Throughout my thesis, the governmentality framework has guided the analysis of how this system of order has been created through diverse disciplinary, incentive, and regulation techniques. A governmentality analysis thinks carefully about how knowledge is being used to classify and simplify social reality into "bits of commensurable information" (Crang, 2003).

De Certeau suggests that analysis and writing are a process of assembling a mosaic of ideas together. Following de Certau's (1986) suggestion, I did not push my analysis and writing to be linear arguments, rather I worked through "juxtaposition and collage that would alter the meaning of each fragment" (cited in Crang, 2003, p. 136), to build a new way of seeing things. Employing a post-structuralist account in this research has critically framed my analysis and writing process as a reflective moment where I look back into how some data have been rendered legible and labelled as knowledge at the expenses of silencing others. As de Certeau puts it, "it would be wrong to think that these tools are neutral, or their gaze inert: nothing gives itself up, everything has to be seized, and the same interpretive violence can either create or destroy" (de Certeau, 1986, p.135 cited in Crang 2012). It is this critical awareness that was indeed a very important element of conducting scholar 
activism.

\subsection{Positionality and Reflection: Being an Engaged Scholar Activist by Practising the Politics of Resourcefulness}

This research is grounded in a post-structuralist approach which acknowledges the role of the researcher in constituting the production of knowledge and of power relations within research (Gibson - Graham, 1994; Rose, 1997; Panelli, 2004). This involves recognizing how particular discourses have become the medium of understanding in the world system and the role of the researchers in co-constituting the production of these discourses (Kitchin and Tate, 2000). Discourses create power structures by prohibiting certain interpretations of reality and creating "temporary truths" as this truth will be the subject of constant discursive struggles and specified by its time and space boundaries (Panelli, 2004). Researchers are encouraged to reflect on how their positions affect the way research is being conducted and research outcomes are constructed from empirical evidence (Bondi, 2009; Scheyvens, 2014). Rose (1997) calls this process reflexivity, which partly consists of understanding the relationship between researchers and their research participants, and acknowledging the way research participants might position and engage with them. Castree et al (2010) emphasize that being reflexive also includes a process of enabling the production of equal power relation between the researchers and their collaborators. One way of doing this is by being clear about our motivation for doing the research, being critical and respectful in engaging with our research collaborators, and being willing to be open to the possibility of our own subjectivity being transformed (Butler and Davies, 2008).

Browne et al suggest (2010) that being reflexive includes a process of making sense of our multiple positionalities in the research process. Derickson and Routledge (2015) warn, however, that being too reflexive can trigger a sense of guilt that is counter-productive to the wider call for researchers to engage in scholar activism. Butler and Davies (2008) also highlight the risk of being too self-conscious in a way 
that will limit the researcher's creativity and capacity. Furthermore, Butler and Davies (2008) raise concerns over the impossibility for researchers to ever give their true identities and positionalities as these are fluid and changing. With these concerns in mind, I will now reflect on my many positionalities, and how these may have shaped the research process.

I am a female Indonesian who was born in a Javanese, lower middle class, Muslim family. Having these social, ethnic, and religious identities meant I was granted with all the privilege of being part of majority groups in Indonesia. I grew up in Yogyakarta, one of the most important well-developed provinces in Indonesia, located on Java Island. Growing up in Yogyakarta meant I had fairly easy access to education compared to the rest of Indonesians living on the outer islands. I received tertiary education in a well-respected public university. Whilst pursuing my undergraduate studies, I was involved in student journalism and movements. This was the time when I learned, through direct encounters with the student movements how to problematize my privilege and practice politics (belajar berpolitik). I joined direct street demonstrations and rallies, critical discussions, and engagement with the wider women, labour, human rights and environmental movements. Despite my educational training in Industrial Engineering, I then chose to formally join several NGOs as my formal occupation and this was motivated by my commitment to be part of the struggle for a more just society.

My experience with NGOs (including working with a women's organization, an international conservation organization and United Nations bodies) has shaped the way I perceive the world and its problems in idealistic ways. On the other hand, I worked as a consultant for government ministries and the House of Representatives. These experiences provided me with pragmatic views regarding development issues and policy making processes. These two views - idealistic and pragmatic - create my social and political identity, norms and values. While this description is very reductive in the sense that it portrays my positionality only by describing my occupations, I am aware that this influenced the way I developed and conducted my research and also how this shaped the way my research collaborators positioned and understood me. Inspired by Gramsci's work, Hall proposes that one's 
positionality and interests are continuously shaped during one's active engagement with struggle, therefore, one's positionality is a "product of articulation" (Li, p. 22). This proposition counters the argument that positionality is fixed, and rather argues that one's positionality is influenced by the specific and situated political engagements and power relations that one is encountering.

Taking into account Hall's argumentation on positionality, in what follows, I recall some of the reflections that I considered relevant and important to this research and highlight some of the challenges that I encountered in relation to the multiple positionalities assumed during the study.

As noted earlier, a politics of resourcefulness guides my attempts to conduct this research as a form of scholar activism. Following Derickson and Routledge's (2015) advice, this politics is manifested in a commitment to share the resources and privilege that my position as an academic affords me in contributing to social struggles. In practicing this commitment, Taylor (2014) suggests an ethics of reciprocity, which I chose to implement by strategically engaging with the environmental and Indigenous movements in Indonesia through my collaboration with AMAN, the REDD+ Taskforce/Agency, and the Bahanei. I offered ideas, not as a prescription, but more as contributions to broader activism. I was directly involved as a consultant for both AMAN and the REDD+ Agency during my fieldwork. This position provided both opportunities and challenges. I was presented with major opportunities to contribute directly to the work and concerns of two organizations that link closely to my study and my politics.

Offered with an opportunity to be a Senior Specialist for Program Development in the REDD+ Agency, I contributed to the work of the Agency in developing REDD+ activities in two REDD+ pilot provinces: Central Kalimantan and East Kalimantan. The position was a paid consultancy job and the work that I delivered to the Agency was not directly related to my research objectives. However, in the attempt to practice the politics of resourcefulness, I sought to engage directly in shaping the production and implementation of REDD+ governmental technologies so that they would align with the vision of socio-ecological justice. My positionality as a 
consultant facilitated a deeper engagement and access to wider data that weren't initially accessible. During fieldwork, district officials were more willing to talk after they learned that I also worked as a consultant for the REDD+ Agency. This position helped in opening some difficult doors while also closing doors to other potential engagements.

The second direct opportunity to practice the politics of resourcefulness is when I was offered the opportunity to assist AMAN in developing a concept of an appropriate REDD+ benefit sharing mechanism for Indigenous peoples. This position was pro-bono although AMAN facilitated and paid the travel cost to two Indigenous communities located in Jambi and North Sulawesi Provinces where I facilitated focus group discussions and conducted interviews. As a consultant for AMAN I was responsible for gathering data, analysing it and developing a concept note based on the empirical situations of the two Indigenous communities that I visited. AMAN's agenda to develop a concept of REDD+ benefit sharing mechanism is not directly linked to my research focus. However, I see this as part of implementing scholar activism where I was directly engaged in the struggle to repurpose REDD+ to benefit the Indigenous communities (Anthias and Radcliffe, 2015; de Freitas, Marston and Bakker, 2015).

The third opportunity to practice the politics of resourcefulness came through the collaboration with two local communities that I had met during the fieldwork in Central Kalimantan. The first community was the Bahanei, which eventually became one of my main research collaborators (see Chapter Seven). The second community was the Tehang, a neighbouring community of the Bahanei. Unlike the formal collaborations with the REDD+ Agency and AMAN that were formalized through the signing of contracts, my collaboration with the two communities took form in the daily encounters during my fieldwork and beyond. I was involved in the series of meetings with local government agencies in Gunung Mas District and Central Kalimantan Province in which the Bahanei advocated for the Indigenous land claim. Together with activists from AMAN Central Kalimantan, my presence in the meeting as part of the Bahanei "advocacy team" was strategically employed to prevent intimidation by the government officials against the Bahanei. My multiple 
positionalities as a PhD candidate, a REDD + Agency official, and part of AMAN's team, were seen as quite strategic to put pressure on the local government officials. Following the feminist geography approach, I sought to develop and extend my research praxis so that it was more participatory in nature, and promoted dialogue and collaboration between academics, activists, and the researched subjects. This approach requires mutual dialogues to develop respect and understanding (Cahill, Sultana and Pain, 2007). However, it is important to note that many critical geographers challenge participatory research because sometimes it is exploited to mask unequal power relations and legitimise processes of appropriation (Cooke and Kothari, 2001).

Drawing on a radical geography perspective, Graeber (2004, p. 11) exhorts scholars to be "self consciously aware and reject any trace of vanguardism", in order not to form a group of elites for others to follow. Whilst contemplating these warnings, this research has been a constant process of negotiation between my own expectation to perform a piece of ethical scholar activism research and the reality of an aid industry where, as a consultant, I was expected to offer a positionality to be "consulted" which implied a "higher" level of knowledge than my research collaborator. Thus, in conducting the research, I had to negotiate a messy complexity of emotions, ethics, positions, boundaries, and inconsistencies that led to confusion in analysing and writing the research results (The Autonomous Geographies Collective, 2010).

Having both carried out research and provided consultancy to AMAN created a close relationship with the AMAN activists that I worked with. I share the same passion and concern as they have but I became uneasy when the critical analysis I undertook made me feel that I may have betrayed their trust. There is a tension caused by the feeling that what I have written is probably going to weaken the social struggle. Chapter Seven of this thesis presents my critical analysis on how a particular Indigenous land claim assemblage can potentially exclude other communities' access to land. I have concerns that this critical scrutiny can be employed by the opponents of Indigenous movement to justify their political position and weaken the 
Indigenous activists struggles using the critical knowledge that has been produced by this research.

Being part of the social activism in Indonesia means I knew most of the Indigenous and environmental activists both professionally and personally. I had concerns that critical analysis in this research would negatively affect both my future professional and personal relationships with the Indigenous movement and activists in Indonesia. I addressed this tension carefully by discussing my initial draft of writing with several AMAN activists and created ways of coming together in understanding a politically sensitive issue. I communicated my true intention and stated my expectation that the critical analysis coming from this thesis might potentially incite positive discussion on Indigenous movement and REDD+. Using a post-structuralist account, Cameron and Gibson (2005) suggest that scholar activists acknowledge the messy and multiple realities of a participatory approach, to embrace the confusion and be ready for both the rewarding and difficult processes. As Pain and Kindon (2007, p. 2809) explain, "participatory research is explicitly about the openness, emergence, surprise, tensions, and irreconcilability that often make up the process of co-researching with non-academics." Acknowledging this messiness of working with my research collaborators and continuously practicing scholar activism had driven this tiring but rewarding research process. In addition, to avoid choosing a harmful framing, I continuously asked for my primary supervisor's suggestions on the approach that I chose, and discussed the diverse implications of these research findings to both the social movement and my future career opportunities.

Reflecting on my three engagements above, I can conclude that I was able to access people, events, and networks that I wouldn't have been able to if I had not been acting as a consultant to both the REDD+ Agency and AMAN, as well as by becoming a member of the Bahanei advocacy team. I worked in the "space of in between-ness", by personally acting and responding to the opportunities that REDD+ had brought to pursue progressive changes that correspond with my political vision of socioecological justice, as well as a researcher who was entangled in the awkward local spatial politics. However this position also created challenges in doing research with the principle of equality between the researcher and research participants. 
Despite attempting to decolonize my research praxis by not speaking on behalf of my research subjects, having the position of a consultant sometimes required me to act otherwise (Howitt and Stevens, 2010).

\subsection{Limitations of the Methods}

This research was conducted with rapid changes in government policy taking place in the background. Researching REDD+ in Indonesia is similar to investigating a moving target. Such a situation creates many challenges for a social researcher, not least around the temporal boundaries for the study. I found myself carried away by the political dynamic and it was difficult to set the time limit when the research should be stopped. The second constraint derived from researching a moving target was the difference in pace between the slow and reflective academic process and the swift changes seen in forest politics. Given this situation and the spirit of a poststructuralist approach, this research is not attempting to represent the whole REDD+ political ecology but rather to explore the particular expressions of REDD+ as they unfolded during my research.

A third constraint derived from performing the role of consultant for both AMAN and the REDD+ Agency. As discussed in the section above, there were both challenges and opportunities in relation to these multiple positionalities. I wonder if performing a more participatory and engaged scholar activism would have been better without the role as a consultant. The paid role as a consultant requires certain deliveries and performance that are not always in line with the principles of scholar activism.

\subsection{Conclusion}

This chapter has sought to describe the approach, methods and ethos that have inspired this thesis. I have also discussed multi-sited ethnography as a mechanism to explore and collect data on REDD+ as a governmental system. Through engaging with three case studies, I have been able to explore the dimensions of of REDD+ 
governmentality in Indonesia. The multi-sited and cross scalar ethnographic method has provided a mechanism to understand how governmentality works to govern human and forest relationships. This research has been guided by the ethos of scholar activism and informed by a politics of hope. As a piece of scholar activism, this research is mainly driven by the emotional effect of the researcher's commitment to contribute to the struggle for social and environmental justice. 


\section{Context Forest Politics in Indonesia: Actors, Interests and Contestations}

\subsection{Introduction}

In introducing new rationalities to forest governance, REDD+ proponents needed to engage with the complexities of forest politics in Indonesia. REDD+ is a abstract program designed by international climate scientists and economists (WertzKanounnikoff and Angelsen, 2009). Its main governing rationale is to conserve forest carbon by offering incentives for developing countries to reduce deforestation and forest degradation (Corbera and Schroeder, 2011; Boer, 2013). In so doing, REDD+ will play a significant role in reshaping Indonesia's forest governance and is conversely shaped by its existing political ecology and economic context (Indarto et al., 2012; Agung et al., 2014; Astuti and McGregor, 2015; McGregor et al., 2015).

This chapter introduces the social and political context upon which the research is situated. It describes the shifting governmental rationalities, technologies, and practices of governing forest and forest people in Indonesia over time. The chapter focuses on how the narratives of development have played out in managing forestland post-colonialization (Li, 1999; Dove and Kammen, 2001). The chapter explains the political ecology of forests in Indonesia - with which REDD+ is required to engage. In doing so the chapter attends to the idioms and discourses employed by the state and non-state actors to legitimize their rationales, policies and programmes while at the same time contest others' rationales and objectives (Colfer, 2010). The chapter is divided into two sections: the first section discusses forest governance during post-independence and the New Order era; the second section examines forest governance during post-Soeharto era and REDD+ inception in Indonesia. 


\subsection{Post-independence and the New Order Era}

Indonesian forests have been the subject of contestation between many forest stakeholders since pre-colonial times (Resosudarmo, 2005; Saich et al., 2010). A range of forest-related discourses have been used to justify certain interests. Stakeholders use a variety of techniques and forms of knowledge to develop discourses and practices to advance their interests while obstructing the objectives of others (Peluso, 1992; Wunder, 2001; Moeliono and Limberg, 2012). This section attends to the politico-economic rationales of forest governance during the New Order era (1966 - 1998) when former President Soeharto was in power. It focuses on the technologies employed by the MOF to produce what constitutes state forest (Fay, Sirait and Kusworo, 2000; Barr, 2006). The state claims over more than $70 \%$ of Indonesia's lands and obscures other forms of land entitlements, including Indigenous tenure rights (Fay and Sirait, 2005, 2010; McWilliam, 2006).

My starting point is the historical analysis of the mechanism by which Indonesia's state Forest Estate (Kawasan Hutan) was established to pave the way for President Soeharto's political objectives and tracing its socio-political and ecological implications. Soeharto rose into power in 1965 to replace Soekarno as the second president of Indonesia. To distance his political regime with the previous government, Soeharto termed his regime as the New Order era while Soekarno's was referred to as the Old Order (Ross, 2001).

\subsubsection{The Making of the State Forests}

In 1967, the New Order passed Law Number 5 on forestry (Basic Forestry Law, hereafter BFL). The law defined forest area as "a particular area gazetted by the government to be maintained as permanent forest (Hutan Tetap)". This definition shows that what is constituted as forest area is not defined purely by scientific forestry and environmental sciences, but encompasses a political process and objectives by which the government (represented by the MOF) has authority to decide. Particular truths about forest were formed using various forestry practices implemented under the umbrella of BFL: including a forest classification system, 
modern forest management, and the establishment of the Forestry Department in 1964 (Fay and Sirait, 2005; Siscawati, 2012). This construction of forests was particularly shaped to serve Soeharto's political objective to lay claim on the majority of Indonesia's lands. Accordingly, other versions of 'truth' proposed by forests' owners and users were rendered invisible. Indigenous people's rights to forest tenure, for instance, were obscured through the nationalist discourse of the state that proposed a unification of Indonesian national culture and identity by classifying all Indonesians as national citizens (pribumi) (McWilliam, 2006; L. Bakker, 2009). This prevented Indigenous communities from claiming indigeneity and its associated rights to land and other natural resources (Afiff and Lowe, 2007; Pramono, 2013).

The management of forests and other natural resources were characterized by patrimonialism and clientelism (Ross, 2001; L. Bakker, 2009). In his research on timber politics in South East Asian countries, Ross (2001) examines the link between the enactment of several forestry policies and Soeharto's strategies to solidify the military's political support for him. After the coup in 1965 that trumped Soekarno's leadership and killed six out of seven of the most senior military generals, Soeharto took the chair as the country's president (Ross, 2001). However, as the leader of the Army Strategic Command (Komando Strategis Angkatan Darat or Kostrad) Soeharto was barely known among the military. According to Ross (2001), after the coup the military was divided into two factions; on one side were Soekarno's followers, and on the other side was what was known as 'green' faction in the military inclined towards the Islamic movement. Realizing the fragile situation and his weak position as a relatively young and inexperienced technocrat, Soeharto's first priority was to solidify the military's political support (Ross, 2001). One of Soeharto's strategies was to 'buy' loyalty from senior military officials by providing them with personal wealth and 'pension' schemes (Ross, 2001). Three quarters of Indonesia's outer islands were covered in dipterocarpaceae forests consisting of mature trees that could be quickly liquidated for Soeharto's plan.

Soeharto's plan, however, was hampered by the Basic Agrarian Law Number 5/1960 (Undang-undang Pokok Agraria, hereafter BAL) that was enacted during the 
pinnacle of agrarian reform spirit in Indonesia under Soekarno and acknowledged Indigenous (adat) rights to land in 1960 (Thorburn, 2002; L. Bakker, 2009). The BAL was formed with idealistic visions on how the nation should govern their land. 'Agraria' refers to more than just land, it also covers the governance of the natural resources contained in it (L. Bakker, 2009). The writers of the law proposed the BAL to be an overarching policy for the management of land and natural resources to replace the socially unequal Dutch Colonial Law (L. Bakker, 2009). The BAL was designed to accommodate the diversity of land tenure systems in Indonesia's Indigenous communities as well as to provide a universal legal system that was required to unite the young nation (L. Bakker, 2009). The BAL was followed by the establishment of National Land Agency (Badan Pertanahan Nasional, hereafter NLA) in 1960. The NLA was mandated to manage land administration according to the principles prescribed by the BAL. However, when Soeharto introduced the BFL the BAL no longer governed forest land (L. Bakker, 2009). BFL was strategically employed by Soeharto's regime to render BAL ineffective.

The BFL was enacted in 1967 in the same year as the Foreign Investment Law. The two policies were part of the legal architecture in the New Order era that were made to legitimize the rent seeking practices of Soeharto's allies (Ross, 2001). The law was followed in 1970 with Government Regulation No.33/1970 on forest land use policy (Tata Guna Hutan Kesepakatan) that demarcates 70\% of Indonesia's land into state forest estate (Kawasan Hutan) (Siscawati, 2012). However, decisions on forest boundaries were often made without a complete public participation processes and based on maps that were often created without examining the facts on the ground (Fay, Sirait and Kusworo, 2000; Fay and Sirait, 2005, 2010).

In the 1980s the MOF developed biophysical criteria to define the State Forest Zone for the outer islands of Indonesia (Fay, Sirait and Kusworo, 2000). The biophysical characteristics used were slope, soil type, and rainfall level (Fay, Sirait and Kusworo, 2000). The criteria were then being employed to classify forests into three major functions: protection, production, and conservation (see Table 4.1) (Fay, Sirait and Kusworo, 2000). Important species and potential for tourism were also considered for zoning classification (Fay, Sirait and Kusworo, 2000). According to the policy, the 
state forest area was classified into: 64.3 million ha of production forest where the aim was for it to be exploited for its timber resources, 30.7 million ha of protection forest, 18.8 million ha of natural conservation areas and nature preserve forest, and 26.6 million ha of convertible forest that generally would be converted into production forest (Siscawati, 2012). This zoning technology is the government's territorialisation strategy in producing spatial units which it could claim control over natural resources (see eg Peluso, 1995; Scott, 1998; Peluso and Vandergeest, 2001). According to Peluso and Vandergeest (2001) the process of territorialisation is the key component in both the pre-colonial and post-colonial government efforts to centralise control over natural resources.

Table 4.1 Forest category and definition

(Fay, Sirait and Kusworo, 2000)

\begin{tabular}{ll}
\hline Forest category & Definition \\
\hline $\begin{array}{l}\text { Production forest (Hutan } \\
\text { Produksi - HP) }\end{array}$ & State Forestland designated for production purposes \\
\hline $\begin{array}{l}\text { Protection Forest (Hutan } \\
\text { Lindung - HL) }\end{array}$ & $\begin{array}{l}\text { Forestland designated for protecting soil and } \\
\text { hydrology }\end{array}$ \\
\hline $\begin{array}{l}\text { Conservation Forest (Hutan } \\
\text { Konservasi - HK) }\end{array}$ & $\begin{array}{l}\text { Forestland designated for conservation purposes. In } \\
\text { this class include national park, nature reserved, } \\
\text { wildlife reserved, other protected areas }\end{array}$ \\
\hline
\end{tabular}

Scientific forestry knowledges were orchestrated to develop rationalities that see Indonesian forests as merely sources of timber (Rhee, 2006; Siscawati, 2012). New practices in managing forest as sources of timber were introduced, such as reduced impact logging (RIL), selective cutting and limitation on cutting allocation in the 1970s (Siscawati, 2012). The new practices claimed to render logging activities in Indonesia sustainable as a pillar of the nation's economic growth. However, the de facto logging activities were far from the vision the policies were seeking to establish. Ross (2001) notes that between 1967 and 1980 the MOF issued licenses for around 3.785 million ha a year for timber extraction, turning Indonesia into a very profitable place to extract resources. This earned Indonesia $\$ 3.2$ billion in 
revenue from timber products in the 1970s, making it the second biggest export commodity after oil (Ross, 2001). In the next section I will discuss the social and environmental ramifications of this vast timber-based 'development' project.

\subsubsection{Governing Indigenous Peoples and Rights}

The BFL differentiates between state forest, that is a region of forest that is not subjected to private rights, and proprietary forest or a region that is sanctioned with private property rights (Wright, 2011). According to BFL a private right over land is usually indicated by the presence of cultivation activities. This classification system led to fallow fields or adat forest owned by Indigenous communities being classified as state forest (Rhee, 2006). Moreover, a new Government Regulation Number 21/1971 that was issued in 1971 as a follow up to the BFL further weakened Indigenous rights by subordinating them to the rights of commercial loggers. Article six in the government regulation states that,

1. The rights of the adat community and its members to harvest forest products...shall be organized in such a manner that they do not disturb forest production;

2. Implementation of the above provision is [delegated to the Company] which is to accomplish it through consensus with the adat community, with supervision from the Forest Service;

3. In the interests of public safety, adat rights to harvest forest products in a particular area shall be frozen while forest production activities are under way (Barber, 1990 cited in Ross, 1996, p. 140).

To further marginalize Indigenous and local communities, the New Order stigmatized the idea of being Indigenous as meaning "backwards", "primitive" or "wasteful" (Li, 2001; Rhee, 2006; L. Bakker, 2009). The stereotype had become an efficient technology to humiliate Indigenous identity. Hence, communities were reluctant to openly declare their identities and utilizing it as a basis for land claims (L. Bakker, 2009). The classification of Indigenous and local communities as deficient subjects has justified state interventions that are concealed in the notion of 
"development" and "modernization" (Dove, 1993, 2006; Dove and Kammen, 2001). These "development" processes rearrange people and their resources in a way that gave privileges to Soeharto and his closest allies' authority to decide how and by whom forest resources can be used (Li, 1999, 2007d; Tsing, 2005; McWilliam, 2006). To effectively run the "development" schemes and to make the government's authority felt throughout the outer islands, a law on Village Governance was enacted in 1979. The Village Law effectively "transformed local leaders from representatives of villagers to representatives of the state" (Rhee, 2006, p. 86).

The reorganization of Indigenous and local communities' property rights to the forest through the above legal apparatuses paved the way for timber industries to flourish in Kalimantan and Sumatra (Ross, 1996). High ranking army officials owned many of these timber industries (Ross, 1996). They formed business alliances with Chinese tycoons, whose business skills boosted the military's lack of business experience, yet because of Soeharto's patronage, the military retained exclusive access to contracts and concessions (Ross, 1996; Siscawati, 2012). The army's companies also often acted as the domestic partner of foreign investments that swarmed after the enactment of the Foreign Investment Law in 1967 (Ross, 1996).

While some of Indonesia's Chinese tycoons joined the ranks of the world's richest men, millions of Indigenous and local communities lost access to their land and agricultural crops (Siscawati, 2012). Before Indonesia's independence in 1945 these communities possessed more flexible mobility in expanding land and opening forest, however, the construction of state brought limitations and law enforcement "to which their interests would be subjected" (L. Bakker, 2009, p. 63). A minority of these communities organised resistance, however this has led to oppression and, in some cases, assassination (L. Bakker, 2009). Other communities pragmatically chose to engage with the timber industries either as a cheap source of labour or as collaborators by supplying additional illegal timbers coming from the forest located outside of the concession areas (Ross, 1996).

The marginalization of Indigenous communities in Kalimantan and Sumatra was further exacerbated by the transmigration policy which began in the early 1970 s 
(Fearnside, 1997). The policy was intended to rationalise land use and management to achieve land efficiency and effectiveness by expanding the agricultural area in the outer islands and reduce population density on the islands of Java and Bali (Fearnside, 1997; O'Connor, 2004; Rhee, 2006). Millions of Javanese migrated to forest areas in the remote parts of Sumatra and Kalimantan in the hope that they would start clearing forests and cultivating rice and other agricultural products. Millions of hectares of forests were opened through 'pioneer slash-and-burn' for agricultural practices (Vayda, Colfer and Brotokusumo, 1985).

The modern farming methods adopted by Javanese farmers was seen as superior to the collective management approach commonly used in the adat communities (Dove, 1993). The communalistic nature of land ownership and swidden culture in these communities were deemed by the state as inefficient and thus subjected to several modernization programmes and policies which included exposing them to 'better and civilized' Javanese migrant farmers (Dove, 1993; Cramb et al., 2009; Fox et al., 2009). This created new pressures and tensions for the forest and the local Indigenous communities. When the initiated new modern agricultural activities were unsuccessful, transmigrants had no other options than to work as labourers for logging companies or taking shortcuts by supplying timber from illegal logging (Ross, 1996).

In the early 1980s the MOF banned the selling of raw log timber and encouraged the development of plywood industries to extract additional value from forest resources (Ross, 1996). However, despite the logging limitation, Indonesia had risen to become the biggest producer and exporter of plywood in the world (Ross, 1996). This was made possible by the continuous supply of timber from illegal logging that supported the plywood industry (Ross, 1996). The environmental implications of the illegal logging practices were particularly concentrated in Sumatra and Kalimantan (McCarthy, 2010). In addition to the environmental destruction, there were the rent seeking practices of the forestry officials both at the national and local levels who intentionally overlooked forestry crimes due to bribes and sometimes committing crimes themselves (A. Dermawan et al., 2011). Corruption, collusion and nepotism, a set of corrupt practices that is well known in Indonesia as Korupsi, 
Kolusi, dan Nepotisme (KKN) have been common throughout forest governance (Robertson-Snape, 1999). The next section discusses the rise of environmental and Indigenous activism that responded to the messiness of Indonesia's forest governance.

\subsubsection{Environmental and Indigenous Activism}

The accumulation of socio-political and ecological problems triggered the emergence of environmental activism by the end of 1970s (Aditjondro, 2003). Initiated by student movements and encouraged by Emil Salim - then the State Minister on Development Supervision and Environment - an environmental group Wahana Lingkungan Hidup Indonesia (Friends of the Earth Indonesia, hereafter WALHI) formed in 1980 (Aditjondro, 2003). WALHI was established as a hub for NGOs focused on and concerned about issues related to environmental problems and natural resources management (Aditjondro, 2003). During the New Order era, the most pressing issue was environmental destruction caused by industrial activities and exploitation of forests resources (Aditjondro, 2003). The movement in Indonesia was influenced and inspired by events and discourses in the international context, such as the publication of Silent Spring by Rachel Corson and the Brundtland report on sustainable development (Pramono, 2013).

Widely supported and funded by the Ford Foundation, an environmental movement in Indonesia emerged and advocated the concept of community based natural resource management (CBNRM) that fostered the principle of participation in forest governance (Siscawati, 2012). The CBNRM principles were translated for the national context and formed what is known as Sistem Hutan Kerakyatan which translates as community forestry system (hereafter SHK) (Siscawati, 2012). SHK is designed as forest management practices that allow for greater community control and access. SHK asserts that forest communities have the knowledge and wisdom to sustainably manage forests that have long been part of their life, not only in relation to economic matters and livelihoods, but also often including social, cultural and spiritual aspects (Siscawati, 2012). By respecting, acknowledging and protecting the 
community's rights over their land and forest, SHK proponents argue that the community will have more incentive to protect the forests (Siscawati, 2012).

This notion, about the importance of intimate human-forest relationships has drawn environmental and Indigenous activists together. In 1993 a small group of WALHI networks and activists gathered to discuss the marginalisation and dispossession faced by Indigenous communities in Indonesia under the New Order regime (Fay and Sirait, 2010). The meeting resulted in two important decisions that have shaped the character of the Indigenous movement in Indonesia. First, responding to growing international Indigenous activism that culminated in the United Nations Declaration of Indigenous Peoples' Rights (UNDRIP), the activists agreed on the term of 'masyarakat adat' as an Indonesian translation for Indigenous peoples (Fay and Sirait, 2010; Pramono, 2013). The adoption of the term was seen as a 'safe' move during the precarious political situation under Soeharto's authoritarian regime as the government itself had started to use the term adat during the establishment of Adat Council in some of the outer island provinces as part of the state's strategy to control Indigenous peoples (Fay and Sirait, 2010; Pramono, 2013). To delineate the position of masyarakat adat from other local people, the activists introduced a normative definition of the term, which is "a human group from the same ancestral lineage who inhabit a certain geographical area and has a distinctive set of value, ideological, economic, political, cultural, and social systems as well as a territory" (Pramono, 2013, p. xx).

The second agreement of the meeting was the formation of Japhama Uaringan Pembela hak-hak Masyarakat Adat, or Network for the Defence of Indigenous Peoples' Rights) (Fay and Sirait, 2010; Pramono, 2013). The network was expected to be able to provide help and advocacy services for dispossessed and marginalized Indigenous people that were victimized by the regime's policies. Toward the end of the Soeharto era in 1998, Japhama activists organized several small meetings to strengthen the position of the Indigenous movement in Indonesia (Fay and Sirait, 2010). The meetings culminated in 1999 in Jakarta, a year after Soeharto resigned from his presidency and amidst the euphoria surrounding the desire for political reform which ignited the birth of hundreds of new civil society organizations. The 
meeting in Jakarta led to the formation of AMAN, a member-based organization of Indigenous people whose main mandate was to struggle for the acknowledgement and rights of masyarakat adat in Indonesia (Fay and Sirait, 2010; Pramono, 2013). A famous line was introduced in the meeting that illustrates how the Indigenous movement positions itself with regard to the state: 'if the state doesn't recognize us, we do not recognize the state' (Fay and Sirait, 2010). This line shows the freedom of expression and level of democratisation that civil society in Indonesia enjoyed in the post-Soeharto era and the changing strategies of engagement with the state. I will discuss this in the next section.

\subsection{Post-Soeharto Era and the Inception of REDD+}

The economic crisis in 1997 that affected several countries in Asia triggered a widespread mass protest in Indonesia that peaked with the resignation of Soeharto as Indonesia's president in 1998. The country underwent political change and adopted a new approach to development (McCarthy, 2000; Resosudarmo, 2004). Groups started to use indigeneity and ethnicity as mechanisms to reclaim and reoccupy lands grabbed by the state and private companies during the Soeharto era (L. Bakker, 2009; Colfer, 2010). After 32 years of silence under Soeharto's authoritarian regime, strong and loud dissent was now audible all over Indonesia (Thorburn, 2002; L. Bakker, 2009). The State had no other option but to take into account the aspirations for change in governing forests and land in Indonesia (Resosudarmo, 2004).

New policies were introduced to reflect the change that was being demanded. For instance, adat forest existence was recognized and classified under the state forest in the revised BFL in 1999 (Resosudarmo, 2004). This recognition also convinced the state to establish a national commission to address agrarian conflict (Pramono, 2013). The new policies, however, often weren't reflected on the ground. Deforestation reached its highest rate and corruption was prevalent in the forestry sector. This section analyses the political dynamic from 1998 until the inception of REDD+ in the country. 


\subsubsection{Reformasi and Decentralization}

In his resignation speech, to calm the widespread protests that had paralyzed Jakarta and other big cities in Indonesia, President Soeharto appointed Vice President Baharuddin Jusuf Habibie, a technocrat who had no political background and support, as his successor (Resosudarmo, 2004). Perhaps, to cut the ties with the previous authoritarian governmental regime, Habibie initiated a lot of breakthrough reform programmes (Thorburn, 2002; Resosudarmo, 2004). Strict censorship of the media was lifted, political prisoners were released, and to gain international support, a referendum to determine East Timor's future was conducted (Resosudarmo, 2004). The economic and political crisis triggered a wave of new aspirations regarding local government, especially in the regions with abundant natural resources, including demands for a more decentralised administrative system and fiscal autonomy (McCarthy, 2000). The aspirations were catered to by the enactment of two decentralisation laws in April 1999: Law No.22/1999 on Regional Governance and Law No.25/1999 on Fiscal Balance, both of which were signed by President Habibie and officially came into effect on the first day of 2001 (Resosudarmo, 2004). The World Bank and International Monetary Fund put pressure on the government to pass the laws as a requirement to access loans (Hadiz and Robison, 2005).

Albeit with ambiguities, the two laws gave authority to local governments, especially district governments, to manage their own natural resources, including forest resources and forestland (McCarthy, 2000; Barr, 2006). Those who supported decentralization argued that it was necessary given the context of Indonesian geographical and socio-cultural conditions to conduct governance closer to the people that would benefit from it. The argumentation is based on the perception that the local government possesses better knowledge for managing their own natural resources and have a better understanding of the needs of the local citizens (Resosudarmo, 2004; Barr, 2006). Another argumentation in favour of decentralisation also highlights the opportunity for voters to hold their local leaders accountable through local election processes. However, later in 1999, due to widespread ecological impacts from hundreds of logging and mining licences issued 
by local governments, a revision of BFL was passed which made provision for the central government to retain its role in managing Indonesian forests (Resosudarmo, 2004). The passing of the revised law met with strong resistance from the regions. Thus, instead of referring to the BFL law, local governments legitimized their actions by claiming the rights to manage and exploit forests based on Law Number 22/1999 on Regional Governance (Resosudarmo, 2004).

Despite the centralising character of the BFL law, the MOF issued and promoted policies that apparently took into account the demand for greater participation and access by local government in managing forests (Aspinall and Fealy, 2003; Moeliono and Limberg, 2012). In 1999, the government issued Regulation Number 6/1999 concerning forest exploitation, which granted authority to district governments to issue small-scale timber concession licenses for up to 100 hectares to individuals, national corporations, or local co-operatives in the forests area that were intended to be converted into other land uses or Areal Penggunaan Lain (APL), the category of land in Indonesia that is governed under the NLA (Resosudarmo, 2004). Another policy was issued in 2000 that gave authority to the district governments to issue licenses for the harvesting of forest products including timber in Natural Production Forests for up to 50,000 hectares (McCarthy, 2000; Thorburn, 2002). The MOF also stated in its policy that the governors of the province would be authorized to issue licenses that spanned the boundaries of two or more districts while the central government jurisdiction applied for concessions that included areas that spanned more than one province (Resosudarmo, 2004). Given the authority to issue concessions, the district governments used these windows of opportunity to increase local revenue by issuing hundreds of new logging licenses.

Researchers have highlighted that the policies enabled rampant abuse by corrupt district leaders and officials (Robertson-Snape, 1999; A. Dermawan et al., 2011). District leaders (Bupati) often issued concessions in exchange for political support from the members of local parliaments or public figures. Burgess et al (2011) argue that there is a linear correlation between the increase in the rate of deforestation in a particular district and its local election period. The study found that near the election time, district leaders would issue concessions as gifts for their supporters or 
to obtain the political and financial capital needed to retain their positions (Burgess et al., 2011). The environmental implications of these concessions being issued were very serious. Resosudarmo (Resosudarmo, 2004) lists some examples of the extensive number of concessions issued in some districts in Kalimantan. Kutai Barat District in East Kalimantan issued 622 small-scale logging permits and Sintang District in West Kalimantan authorized 409 licenses to be granted (Resosudarmo, 2004). Just three years since its implementation, the total forest area that had been over-logged reached around 2 million hectares nationally (Resosudarmo, 2004).

\subsubsection{Drivers of Deforestation}

In 2009, the MOF (Regulation Number 30/2009, Article 1 Point 10) defined 'deforestation' as a permanent change from a forested to a non-forested area caused by human activity (Indarto et al., 2012, p. 2). Meanwhile, Article 1 point 11 defines 'degradation' as a reduction in the quantity of forest cover and carbon stock over a certain period caused by human activity (Indarto et al., 2012, p. 3). Based on historical data, the Ministry of Development Planning estimates the annual deforestation rate in Indonesia to be around 1.125 million ha, while the annual degradation rate is estimated at 0.626 million ha (Indarto et al., 2012). The MOF identifies several activities that directly cause deforestation and forest degradation (Indonesian REDD+ Task Force, 2012). These include conversion of forests into other land uses, such as mining and plantation; logging (both legal and illegal); and forest and peatland fires all of which are discussed below. The Strategy also highlights underlying factors that contribute indirectly to the increasing rate of deforestation and degradation, such as rising global demand for timber and other forest products, population and demographic changes, and weak forest management (Indonesian REDD+ Task Force, 2012).

\section{Competing Land Uses for Plantation and Mining}

Data from a national NGO, Sawit Watch, shows a swift increase in palm oil estates covering an area of 1.6 million ha in 1989 rising to 8.4 million ha in 2010. Another main driver of land use change is mining. Prior to 2008, data from the MOF only show 344,000 ha of forest under lease-use permits, i.e., a permit that grants the right 
to mine within state forest areas. However, researchers argue that, in reality, mining in forest areas covers much more than the official data acknowledged by the MOF. This argumentation is supported by the unavailability of data and record on smallscale illegal mining operations in forest areas (Resosudarmo et al, 2009). Moreover, due to decentralisation policies many local governments have issued mining permits in the area that they classify as being for other land uses, while according to the MOF are part of the state forest. In 2004, the government prohibited open-cast mining in the protection areas, however, 13 companies managed to secure a total of 850,000 ha of land before the ban took effect (Resosudarmo et al, 2009). Aside from the environmental impact on forest cover and biodiversity, mining and plantation activities often triggered conflicts with Indigenous and local communities (Mahanty and McDermott, 2013).

\section{Logging and Forest Fires}

Once known as the biggest exporter of plywood, Indonesia is also often seen as holding the record for the amount of illegal logging that occurs (Steni and Hadad, 2012). According to researchers there are two differences with regard to forest types regarding how illegal logging is conducted. In the protection and conservation forests, illegal logging occurs without permits. In the production forest, illegal logging ensues through, among others, the felling of timber outside the allocated permit's area, manipulation of felling quotas, and the clearance of the forest initiated for plantation or mining where concession holders often failed to establish the proposed activities.

In the areas proposed to be crop estates and industrial plantation forest, once the wood has been logged, the forest or peatland is usually cleared using fires as it is the fastest and cheapest clearing method (Colfer, 2010). The government has banned this slash and burn practice. However, without proper monitoring and law enforcement, many companies still prefer to clear their plots using this method. The MOF has established the Forest and Land Fire Management Centre (Pusat Pengendalian Kebakaran Hutan dan Lahan or Pusdalkarhutla) and the Forest and Land Fire Management Unit (Satuan Pelaksana Pengendalian Kebakaran Hutan dan Lahan or Satlakdalkarhutla), as well as a national coordination team for managing 
forest and land fires. In addition, many donors and NGOs have tried to encourage the participation of local people in establishing community based forest fire management units. Nonetheless, almost every year up to now, in several provinces, such as in Riau, Jambi, and Central Kalimantan, forest and peatland fires have continued to be a routine problem. In the most recent forest fires in Riau, during the dry season in 2014, the REDD+ Agency obtained satellite images of forest fire hotspot occurrences in regions belonging to some big concessionaires. However, instead of revoking the companies' permits, the police officers often only prosecuted the companies' staff members that were tasked with clearing and burning of the areas. This reflects the social and political obstacles in enforcing environmental law and regulations.

\subsubsection{The Role of Social Movements in Reforming Forest Governance}

In the wake of the New Order's demise, Non Governmental Organizations (NGOs) employed conservation and sustainable development discourses to draw attention to the escalating environmental degradation and its associated socio-political impacts (Resosudarmo, 2004, 2005). Activists were actively problematizing several policies of the New Order's authoritarian approach. One particular target was Law Number 5/1979 on Village Government, which according to the activists was trying to homogenize local communities to render them manageable and governable (Ross, 1996). The law efficiently replaced adat structure and culture with a 'Javanese model' of social structure and local governance that resembled a 'pseudo-military model' that depended on the hierarchical control and resources from the national government (Ross, 1996). Villages were established and their borders were drawn on a map often without taking into consideration the socio-cultural delineation among communities. The borders have been the subject of tensions and contestations horizontally among neighbouring communities and vertically between the communities and the state or the private sector (Ross, 1996; Fay, Sirait and Kusworo, 2000).

Another significant milestone in problematizing the messiness of forest spatial 
governance was through the publication of ICRAF's (the World Agroforestry Research Centre) research on the forest gazettement process (Fay, Sirait and Kusworo, 2000). The study highlighted that only 11\% of forest in Indonesia had been gazetted, which left almost $90 \%$ of forest with unclear boundaries (Fay, Sirait and Kusworo, 2000). This caused multiple interpretations of the status of the land and induced overlapping claims at particular locations. Uncertainty and inconsistencies in national and local spatial planning encouraged corrupt and rent seeking practices by actors that benefited from retaining the status quo (Barr, 2006; A. Dermawan et al., 2011; Brockhaus et al., 2012).

Article 1point 3 of the BFL defines the process by which state forest is established. State forest is defined as "a particular area designated and/or gazetted by the government to be maintained as permanent forest" (hutan tetap). The use of the grammatical conjunction 'and/or' in the article above means that state forest could be established only with the process of designation (ditunjuk) without being further gazetted (ditetapkan) (Indarto et al., 2012). The implication of this rule is significant. The MOF realized that the BFL had given them authority to avoid lengthy processes of gazettal and rather to simply chose to designate a particular plot of land as part of the state forests (Indarto et al., 2012). As of 2011, only around 14.24 million ha of forests had been fully gazetted (Indarto et al., 2012). This has major ramifications in terms of unresolved conflicts over forest boundaries, both with the communities and local governments. Nevertheless, the MOF still persistently issued forest concessions for areas designated as state forests but not yet gazetted, and let the concessionaires directly face the conflicts on the ground by themselves (Indarto et al., 2012; Agung et al., 2014).

In 2011, five district heads proposed a judicial review of Article 1 point 3 of the BFL Number 41/1999. In 2012, the Constitutional Court granted the request and declared the phrase 'designated and or' as unconstitutional and unenforceable (Wells et al., 2012). The article now reads: "Forest zone is a particular area gazetted (ditetapkan) by the Government to be maintained as permanent forest (Hutan Tetap)" (Wells et al., 2012). There are four steps to be taken by the government for the gazettal process, these are; 1) forest zone designation, 2) administrative 
demarcation of forest zone, 3) forest zone mapping, and 4) forest zone determination (Wells et al., 2012). The court ruling was expected to address the question about the legal status of the state forest areas and to promote the clarification of conflict over land tenure between the state and the communities (see Chapter 7).

The MOF together with the Indigenous and environmental activists organised an international conference on forest tenure in Lombok in 2011 (Agung et al., 2014). The conference opened the opportunity for tenure reform in Indonesia. Activists were advocating a road map of forest tenure reform that relies on three interrelated approaches: harmonisation of policies, conflict resolution, and the advancement of community access to forest (Safitri et al., 2011). The MOF established a special division for tenure conflict and adopted a two-way dialogue approach in addressing conflict instead of more common legal prosecution of local and Indigenous communities (Safitri et al., 2011; Situmorang et al., 2013). Despite these reforms, there are still many challenges faced by environmental and Indigenous activists in advancing reform in the forestry sector, including ingrained cultures of corruption (Dermawan et al., 2011).

The Anti-Corruption Commission (2012) conducted a study in the Directorate General of Planning in the MOF to understand underlying factors that drive corrupt practices. The study revealed 17 types of corruption in the forestry sector (KPK, 2012). However, it was clear that the structural problems of forestry corruption do not only occur within the MOF, but involve other ministries and state agencies. Based on the findings of the study, the Anti-Corruption Commission initiated a new platform involving 12 ministries and state agencies to refine forest governance in Indonesia (Agung et al., 2014; Aspinall, Mietzner and Tomsa, 2015; Dermawan and Sinaga, 2015). A Memorandum of Understanding (MoU) was prepared and would be signed by each of the ministers to show their commitment to getting involved with the struggle to fight forestry corruption. The Anti-Corruption Commission asked several environmental activists to be involved in the platform to provide assistance and advice. One of the activists I interviewed explained that it was initially planned to call the platform a 'MoU for forest governance reform', however, the MOF insisted 
that the name was inappropriate and implied the inability of the MOF to carry out their duties. Finally, to find common ground and to facilitate the MOF's aspirations, the platform was titled 'MoU of 12 ministries and state agencies in accelerating the forest gazzetement process' later known as Nota Kesepakatan Bersama (NKB).

The NKB was translated into 93 national action plans that were divided between the relevant ministries and were to be implemented between 2013 and 2016 and monitored by UKP4 (KPK, 2013). One of the highlights of the platform was the involvement of The Human Rights (HR) Commission as one of the signatories (Widhiarto and Gunawan, 2014). The HR Commission advocated a national inquiry programme aimed at documenting the violation of Indigenous and local communities' tenure rights (Widhiarto and Gunawan, 2014). The national inquiry has strengthened the presence of the human rights approaches into the forest governance. Thus, it has highlighted the need to protect Indigenous and local communities against private sector interests.

According to an environmental activist I interviewed, one of the biggest challenges in accelerating the gazettal of forest boundaries is to address land tenure claims inside the forest area. There are some issues to be addressed in order to seek clarity over land claims within state forest areas. First, there is the dichotomy in managing land in Indonesia that is the separation between forest land and other land uses (areal penggunaan lain - APL) (Sahide and Giessen, 2015). The only state agency that has the authority in managing forest areas is the MOF, while land located on nonforest areas is governed under the authority of the NLA (Safitri, 2014; Sahide and Giessen, 2015). However, the only state agency that has the authority to issue land ownership certificates is the NLA. Since the state forest areas are under the jurisdiction of the MOF, the NLA could not enter the forest and issue certificates that are needed to give legal status and clarification over land ownership to Indigenous communities, local peasants, and transmigrants (Safitri, 2014). Second, there is no technical mechanism for addressing conflict and claims over land within the state forest areas. In order to address this problem, several activists who served as advisors for the NKB proposal to the Anti-Corruption Commission initiated a joint 
regulation (Peraturan Bersama - Perber) between four related state agencies to address the above problems (Safitri, 2014).

The joint regulation on 'Procedures for the Settlement of Land Tenure in State Forest Area' was issued in October 2014 and signed by four ministries: the MOF, the NLA, the Ministry of Home Affairs and the Ministry of Public Works (Safitri, 2014). The regulation was expected to accelerate the finalization of land tenure conflicts within the state forest areas and to produce forest areas that would be free of land conflicts (Safitri, 2014). Interviews with some activists suggest that the regulation is quite progressive in terms of changing the old paradigm of monolithic-power in governing forestland. The regulation gives authority to the NLA to issue certificates as soon as a parcel of land is given by the MOF to the third parties (successful applicants) (Safitri, 2014). Previously it was considered to be a criminal act when the NLA encroached upon the MOF's jurisdiction. In addition to the changing of authority, the regulation also advocates for bigger agrarian reform as the policy clearly aligns with the BAL introduced in the Old Order period. The regulation stipulates that if the land has been cultivated for more than 20 years then the rights to it will automatically be transferred to the cultivator (Safitri, 2014). This policy opens the possibility for the advancement of reterritorialization and land redistribution in Indonesia.

On the other hand, however, conservationists are questioning whether the regulation would be used to 'legalize deforestation' and function as a 'time bomb' for forest destruction (see eg Handadhari, 2015; Meijaard, 2015). Conservationists allege that the regulation is just a disguise to allow forest conversion under a morally ethical motivation to increase community rights and stimulate rural development. Meijaard (2015) argues in his op-ed as follows,

But realistically, what will communities or individual people do when they can get legal title to what was previously state owned land? Your guess is as good as mine, but I would think many will immediately sell their land to whoever is the highest bidder: likely industrial-scale companies investing in oil palm, pulp and paper, rubber, and mining. 
He further argues that previous similar policies, such as the MOF regulation which allowed district heads to allocate 100 ha for logging licenses to communities through cooperatives or individually owned national companies has caused extensive deforestation (Meijaard, 2015). An environmental activist who serves as the advisor to the NKB and the initiator of the joint regulation, Myrna Safitri, argues in her article that the conservationists' arguments were based on the apolitical paradigm which put the blame for Indonesia's deforestation on the local and Indigenous communities instead of plantation, logging and mining companies (Safitri, 2015). She further highlights the history of the state's appropriation of Indigenous lands as a fact that cannot be erased from the nation's dark past and it becomes the responsibility of the government to undo the injustice that had been done such as through the Joint Regulation (Safitri, 2015).

\subsubsection{REDD+ Inception}

It is within this fraught political context that REDD+ is being introduced. Before the inception of REDD+, various multilateral and bilateral initiatives had been trialled in Indonesian forests (Indarto et al., 2012). Indonesia is one of the world's richest flora and fauna hotspots; its conservation has always been a focus of attention of many multilateral organizations and foreign governments (Wells, 1999; Blom, Sunderland and Murdiyarso, 2010). Moreover, often the ratification of a new policy or the enactment of a new law that is considered to be part of good governance is part of a requirement for the commitment of international aid or debt. In 1990, the government adopted the Convention on International Trade in Endangered Species of Wild Fauna and Flora (CITES) through Law Number 5/1990 (Soehartono and Mardiastuti, 2002). CITES requires its country members to have a set of policies aimed at controlling and monitoring the trade of endangered animals (Soehartono and Mardiastuti, 2002). Indarto et al (2012) argue that Indonesia has yet to enact the required policies, thus, the conservation of endangered flora and fauna are still at risk. Another important global environmental governance ratification was the United Nations Convention on Biological Diversity (CBD). The ratification is legalized through Law Number 5/1994 and translated into five targets for 
government policies and programmes under the term Indonesian Biodiversity Strategy and Action Plan (IBSAP) (Indarto et al., 2012). Despite its comprehensive approach, IBSAP is a set of non-legally binding policies, hence, there is no enforcement ensuring their implementation.

In 2002, the government joined the United Nations Forum on Forests (UNFF) and adopted the principles of Sustainable Forest Management (SFM) (Indarto et al., 2012). Five priority policies were established as the National Development Programme in the forestry sector, covering: eradication of illegal logging, forest fires control, forestry sector restructuration, forest rehabilitation, forest conservation and reforestation (Indarto et al., 2012). Despite a very good and comprehensive policy, its implementation was a different story. Nevertheless, Indonesia's involvement in the UNFF had paved the way for the preliminary Memorandum of Understanding with the European Union (EU) in implementing Forest Law Enforcement Governance and Trade (FLEGT) programme aimed at reducing illegal logging and strengthening Indonesia's forest governance (Indarto et al., 2012; van Heeswijk and Turnhout, 2013; Nurrochmat et al., 2014).

The above narrative on the changing dynamic of forest politics will shape and transform the way REDD+ unfolds in Indonesia. The government of Indonesia, through the MOF, has prepared to adopt REDD+ since 2007. It is proposed that the implementation of REDD+ in Indonesia can reduce deforestation to $50 \%$ of its current rate and bring $\$ 2.5$ to $\$ 4.5$ billion in carbon credit income per annum to the nation (Agung et al., 2014). REDD+ proponents argue that the credit could assist in reducing pressure on the forests from extractive industries while sustaining the country's economic growth. REDD+ is also expected to improve the livelihood of around 6 to 30 million people who depend directly on forests in Indonesia for their economic income (Agung et al., 2014).

Indonesia has committed to reducing its GHG emissions by $26 \%$ by 2020 or $41 \%$ with international support and has positioned forests as its key mitigation sector (Astuti and McGregor, 2015). Although the announcement of commitment, which took place in the 2009 G20 meeting in Pittsburgh, had positioned Indonesia as a 
global leader in mitigating climate change, the commitment got a mixed reception in Indonesia (Indarto et al., 2012). Nevertheless, the commitment facilitated new partnerships with donor countries to support the MOF in reducing carbon emissions from the forestry sector. Indonesia joined two multilateral initiatives on REDD+ in 2009: the World Bank's Forest Carbon Partnership Facility (FCPF) and the UN-REDD programme (Dixon and Challies, 2015; McGregor et al., 2015). The UN-REDD policy board approved Indonesia's proposal and set up a UN-REDD Indonesia programme hosted by the MOF (Situmorang et al., 2013). The Indonesia programe ran for three years from 2009 - 2011 with a total fund of US\$ 5.6 million and its objective was to achieve three key outcomes: 1) improving multistakeholder participation and building consensus among forest actors at the national level, 2) developing national REDD+ architectures, such as, REDD+ National Strategy and benefit sharing mechanism, 3) increasing capacity at the sub-national level in implementing REDD+ (Situmorang et al., 2013). UN-REDD in Indonesia supported the Ministry of Development Planning in developing the first version of REDD+ National Strategy, documenting and collecting historical carbon emissions data to establish initial Reference Emissions Level (REL) at the province level, and designated and supported Central Sulawesi as its REDD+ pilot province (Indarto et al., 2012).

Through the Indonesia Australia Forest Carbon Partnership, the government of Australia signed a bilateral agreement on providing funding for the development of REDD+ demonstration activities (Atmadja et al., 2014). Another country that committed to assist Indonesia in a Joint Programme on Adaptation and Mitigation of Climate Change in forestry through afforestation and reforestation mechanisms was South Korea (Indarto et al., 2012). However the most significant bilateral agreement on REDD+ was through the Letter of Intent (LoI) signed with the government of Norway in 2010 (Government of Indonesia, 2010b)(Caldecott et al., 2013). The US $\$ 1$ billion cooperation agreement is divided into three phases; preparation, transformation and contributions for verified-emission reduction. In its initial phase the tasks of implementing the Lol's agreements were divided between three different state agencies and led by the Coordinating Ministry for Economic Affairs. They are the Ministry of Development Planning to prepare for the REDD+ Strategy, the MOF to establish the pilot provinces, and UKP4 to prepare for the REDD+ Agency 
(Indarto et al., 2012). At the end of 2010, a REDD+ Taskforce was established through a Presidential Regulation and its main mandate was to prepare the legal and institutional infrastructure for REDD+ implementation (see Chapter Five). The next chapter will further discuss the Taskforce's rationalities, strategies and practices in implementing and governing REDD+ in Indonesia.

\subsection{Conclusion}

This chapter has explained the historical transition of forest politics in Indonesia. It has shown troubled history of governance issues and power struggles. The chapter discusses various governmental policies, laws, and technologies being deployed by the state to manage human-forest relations and the rationalities employed to legitimize particular approaches. During the governance of the New Order era, forest areas were established to cater to the regime's political and economic interests. Dozens of regulations were designed and enacted to circumvent the rights of Indigenous and local communities. The regime relied on disciplinary and sovereign technologies enforced by the state's apparatuses, such as, the police and the military, to shape the conduct of communities and activists and how they could engage with the state. Dissent and resistance were repressed by the New Order regime, thus, leaving the regime to freely exploit forests and forest resources for more than three decades. The socio-ecological ramifications of this exploitation are extensive: millions of Indigenous people were displaced and oppressed while millions ha of dense forests were cleared.

The post-Soeharto period beginning in 1998 has seen rapid changes in the forestry sector. Local government has had more participation in managing forests and forests resources due to the decentralisation policies. This doesn't mean, however, that the local government's interests were compatible with the socio-environmental justice interests of the Indigenous and environmental activists. Research suggests that during the Reformasi period deforestation reached its highest rate (Resosudarmo, 2004). Corruption and rent seeking practices were still prevalent and have become part of the challenge civil society continuously battle against. Nevertheless, the post-Soeharto period opened up new spaces of engagement 
through which activists have influenced the policy making processes and problematized the New Order's unjust legacies. Multiple new regulations and initiatives have emerged as the result of activists' involvement and advocacy on democracy, Indigenous rights and sustainable development. These idioms of hope are, of course, still confined and discussed in the form of policies instead of mainstreamed in the practices of government.

REDD+ emerged in 2007 as a new opportunity to reform forest governance and soon became the key mitigation strategy the government adopted to achieve its climate commitment. The political ecology context discussed above shapes the way REDD+ unfolds in Indonesia. Unless REDD+ programs are designed to take into account the complexities of diverse interests driving national and local actors who currently benefit from the status quo, REDD+ will struggle as a strategy for carbon reduction. The next chapter will specifically discuss the first installment of REDD+ architecture and the mainstreaming of its rationale as neoliberal environmental governance. Central to these attempts were efforts by REDD+ proponents to equate REDD+ implementation as a strategy for refining the messiness of Indonesia's forest governance. 


\section{Case Study One The REDD+ Taskforce: Governing Carbon and Transforming Forest}

Politics

\subsection{Introduction}

The REDD+ program seeks to reshape the way people value, govern and interact with forests. Rather than managing forests according to interests in timber, conservation, land or livelihoods, REDD+ encourages forms of forest management that prioritise carbon (Angelsen et al., 2012). While international negotiations are shaping the rules of the program, how it takes place on the ground will depend on its interpretation and implementation in different places. Drawing on this concern and aimed to address the first research objective through case study 1 , this chapter is interested in the governmental technologies the REDD+ Taskforce (Satuan Tugas $R E D D+$ ), an ad-hoc body formed by Presidential decree to design and implement REDD+ readiness activities in Indonesia, created to mainstream the program from 2010-2013. Following the detailed explanation of the research's theoretical framework in Chapter 2, this chapter develops the governmentality approach to focus on how the Taskforce sought to introduce REDD+ carbon rationalities to forest politics. Based on extended qualitative research discussed in Chapter 3, I identify three governmental strategies that the Taskforce employed to normalise REDD+ in Indonesia: adopting and promoting the carbon discourses circulating amongst global REDD+ communities; making carbon visible and governable through mapping technologies; and implementing participatory technologies to encourage pro-REDD+ subjectivities.

I argue that in some ways the Taskforce has been successful in building awareness of forest carbon amongst forest stakeholders in Indonesia. National civil society organisations, in particular, appear to be supportive of REDD+ however they emphasise the discourse of "co-benefits" informed by social and environmental 
justice. For others forests remain sources of timber and land, and new strategies are required if REDD+ is to have substantial impacts on forest governance in Indonesia. The Taskforce's efforts reveal the difficult and contested processes through which global climate change programmes come to be embedded in national arenas.

The rest of this chapter is divided into five sections. The first section introduces the REDD+ Taskforce. The second section reports on the governmental technologies that the Taskforce created to introduce and mainstream REDD+ in Indonesia. The third section discusses the effects of the technologies on Indonesia's forest politics. The fourth section describes both the establishment and dissolution of the REDD+ Agency. The chapter ends with conclusions regarding the success or otherwise of the REDD+ Taskforce in mainstreaming carbon rationalities in forest governance in Indonesia.

\subsection{The REDD+ Taskforce}

Seeking profits from extractive industries such as mining, logging and plantation development has been the dominant rationality governing Indonesian forests (see Chapter 4). This paradigm, tainted occasionally with rent seeking practices and backed by political gangsterism, continues to weaken forest governance and accumulate resources for the benefit of a small elite (Saich et al., 2010). Consequently, an abundance of problems such as conflicts over tenure, forest boundary disputes, concession overlaps and corruption, are typically found in the country's forest management (Indarto et al., 2012). Taking the above issues into account and considering the complexities and claims of cross-sectoral bureaucracies, preparing REDD+ implementation in Indonesia is an unenviable task (Caldecott et al., 2013). Nevertheless, REDD+ is positioned as a key element in realizing Indonesia's pledge to reduce emissions and has attracted plenty of donor attention (Indarto et al., 2012). The most significant offer was from Norway, which agreed to enter into a partnership worth US\$1 billion aimed at developing Indonesia's capacity to implement REDD+ (Government of Indonesia, 2010b). The LoI, discussed in Chapter 4, paved the way for the establishment of the REDD+ Taskforce through Presidential Decree Number 19/2010, which aims to accelerate 
the national REDD+ readiness processes (Government of Indonesia, 2010b). The Decree mandates the Taskforce develop a REDD+ National Strategy, a policy document that outlines how the government can move towards improved carbon management (Government of Indonesia, 2010a). If the REDD+ Taskforce, and the REDD+ programme more generally, is successful, it will have widespread impacts on human - forest relations, forest politics and forest subjectivities in Indonesia.

This chapter approaches the REDD+ Taskforce from the perspective of governmentality, which, as described in Chapter 2, is an approach that directs attention to the techniques through which the state and non-state actors seek to direct the conduct of populations (for related work on climate governmentality see Paterson and Stripple, 2010; Lövbrand and Stripple, 2011, 2013; Gupta et al., 2012; Boer, 2013). This is achieved through calculative technologies, such as statistics and mapping technologies, to manage the health and productivity of populations by disposing people towards things in particular ways (Dean, 2009). Once disposed, populations self-govern their behaviours according to shared norms, rationalities and practices that are considered to be in the common good (see Chapter 2 Cruikshank, 1999; Lemke, 2001). With these insights in mind I now turn my attention to the REDD+ Taskforce and how it sought to govern forest carbon and transform forest politics through REDD+ in Indonesia.

Having strong Presidential support, the Taskforce was established within the UKP4. However its formation as an ad-hoc body was perceived as having little legitimacy or authority to orchestrate REDD+ governance among related ministries (Antara News, 2011; Adi, 2013). One of the Taskforce's deputy stated in an interview,

It's [REDD+ implementation] like trying to solve all the political economic problems of Indonesia's development. On one hand, we [the Taskforce] have to convince diverse actors to support our intention to implement low carbon economy through REDD+ ... On the other, we [the Taskforce] do not have enough legal legitimacy and political authority compared to other ministries that were already in the [government] system for decades. You know ... 
sometimes they [other ministries] might think that we [the Taskforce] are just a "new boy" with a stubborn will (Interview, Yamadhi, June 2013).

Luttrell et al (2012) highlight President Yudhoyono's tendency during his leadership to create ad-hoc bodies and commissions to address bottlenecks in achieving government's goals, instead of tackling the appointed ministries head on. This approach sparked tensions between the existing bureaucracies and the newly established institutions (Luttrell et al., 2012). Awkward relations exist between MOF and the Taskforce as there have been some instances in which the former's bureaucrats have been undermining and questioning the latter's capacity and authority in governing REDD+ as has been illustrated by the above quote. However strong the President's support for the Taskforce, there remain bureaucracies and political constellations that have little interest in the REDD+ agenda (Luttrell et al., 2012).

The appointment of Kuntoro Mangkusubroto as the Taskforce's leader, while well received by donors due to his acclaimed role in post-tsunami work, contributed to further tensions. Ministries were reluctant to engage too openly due to his dual role as head of UKP4, the body authorized by the President to review how ministries performed rather than to execute government's programmes. One of the informants in the MOF highlights her disappointment by saying,

We [Ministry of Forestry] have done our best to prepare REDD+ inclusion as part of the Bali outcomes ... and now someone else wants to take over the result from us. I don't even know how come a government institution [UKP4] that has no mandate to execute a program suddenly wants to be in charge for the works that suppose to be in the authority of this ministry... that is just ridiculous! (Interview, Yusliana, July 2013, emphasis added)

On the other hand, strong support for the Taskforce's work comes from some NGOs (both national and international NGOs), which welcome opportunities for wider and direct engagements in shaping the development of REDD+ policies and broader forest governance. Supportive NGOs indicated in interviews that the formation of an 
independent Taskforce was essential in ensuring the process was participatory, something that would not have happened if it were led by an existing ministry. Hence, the President's decision to establish the Taskforce was considered by many to be a bold statement of a "business not-as-usual approach in forest governance reform" (Interview, Yandiman, May 2013). However, it is also seen as potentially creating confusion and overlap with MOF responsibilities (Luttrell et al., 2012).

The REDD+ Taskforce originally had six Working Groups focused on: the REDD+ National Strategy; REDD+ Institutions, Funding Instruments; Measurement Reporting and Verification (MRV) and Moratorium Implementation; Pilot Provinces; and Communication and Multi-stakeholder Engagement (Satgas REDD+, 2012). Members of the Working Groups were representatives from technical ministries and state agencies including the MOF, Ministry of Development Planning (Bappenas), National Land Agency (NLA), Ministry of Finance, Ministry of Home Affairs, MOE, National Council on Climate Change, Ministry of State Secretary, and UKP4 (Satgas REDD+, 2012). Members were also drawn from environmental NGOs and Indigenous community organisations, such as AMAN, ICEL (Indonesia Centre for Environmental Law), WWF (World Wide Fund for Nature) Programme Indonesia, and HUMA (Association for Community and Ecology-Based Law Reform) (Satgas REDD+, 2012). Supported by a US $\$ 30$ million start-up fund as part of the NorwayIndonesia partnership (Caldecott et al., 2013), the Working Groups were formed as technical teams within the Taskforce, responsible for delivering the preparatory work required for enabling REDD+ implementation.

Due to slow progress in completing its mandates, the Taskforce had its nine- month appointment initially extended until December 2012. An additional four Working Groups were formed on Legal Review and Law Enforcement, REDD+ Mainstreaming, Knowledge Management, and the Moratorium was separated from MRV to form Working Groups of their own (Satgas REDD+, 2012). A third version of the Taskforce maintained the 10 WGs and finished its mandate in June 2013 (Satgas REDD+, 2012) (Satgas REDD+, 2013a) (see Table 5.1). The breadth of issues addressed by the Working Groups emphasises complexity and effort involved in implementing REDD+ 
in Indonesia and the challenge of introducing carbon rationalities to existing forest politics.

Table 5.1 Working Groups of the REDD+ Taskforce

\begin{tabular}{|c|c|c|}
\hline Taskforce version 1 & Taskforce version 2 & Taskforce version 3 \\
\hline \multicolumn{3}{|c|}{ Formation } \\
\hline Based on the Presidential & Based on the Presidential & Based on the Presidential \\
\hline Decree No 19/2010 & Decree No 25/2011 & Decree No 5/2013 \\
\hline \multicolumn{3}{|c|}{ Duration } \\
\hline September 2010 - June & July 2011 - December & January 2013 - June \\
\hline 2011 & 2012 & 2013 \\
\hline \multicolumn{3}{|c|}{ Working Groups } \\
\hline REDD+ National Strategy & REDD+ National Strategy & REDD+ National Strategy \\
\hline REDD+ Institution & REDD+ Institution & REDD+ Institution \\
\hline MRV Strategy and & MRV Strategy and & MRV Strategy and \\
\hline Moratorium & institution & Institution \\
\hline \multicolumn{3}{|l|}{ Implementation } \\
\hline Pilot Provinces & Pilot Provinces & Pilot Provinces \\
\hline Communication and & Communication and & Communication and \\
\hline Stakeholder Engagement & Stakeholder Engagement & Stakeholder Engagement \\
\hline \multirow[t]{6}{*}{ Funding Instruments } & Funding Instruments & Funding Instruments \\
\hline & Moratorium Monitoring & Moratorium Monitoring \\
\hline & Legal Review and Law & Legal Review and Law \\
\hline & Enforcement & Enforcement \\
\hline & REDD+ Mainstreaming & REDD+ Mainstreaming \\
\hline & Knowledge Management & Knowledge Management \\
\hline
\end{tabular}

During the three years of its appointment, the Taskforce published 387 documents, developed a REDD+ National Strategy, finalised the draft of MRV National Strategy5,

\footnotetext{
5 The MRV National Strategy and Plan provides the basis for Indonesia to implement an incentive based carbon reduction mechanism. The Strategy is intended to guide the process
} 
appointed pilot provinces - where REDD+ activities will be trialled out, and prepared the architecture of the REDD+ Agency - which continued the Taskforce's work from 2014. The National Strategy outlines five main pillars that have to be completed to set high quality standards for forest carbon mitigation activities (Indonesian REDD+ Task Force, 2012). One of the pillars highlights the need to change forest governance by mainstreaming REDD+ in Indonesia. The formation and themes of the Working Groups (particularly those on REDD+ Mainstreaming and Communication and Multi-stakeholder Engagement) reflect the embedded political and structural challenges that the Taskforce are facing to change the conduct of forest stakeholders in ways that are oriented towards carbon conservation. The following section details three of the influential governmental strategies adopted.

\subsection{Normalising Carbon Rationalities}

The following discussion identifies three governmental technologies being adopted by the REDD+ Taskforce to mainstream the program in Indonesia. Each attempts to not only make the management of forest carbon possible, but also to make it "normal" or "commonsense" within a forest politics context that has never been concerned about carbon. The technologies were identified through interviews and analysis and involve the introduction and promotion of carbon concepts and languages; rendering forest carbon visible through mapping practices; and encouraging the production of pro-REDD+ subjectivities. In each case the focus is on how REDD+ is being introduced to Indonesia (Dean, 2009).

\subsubsection{Communicating Forest Carbon}

In Indonesia forest governance has traditionally been shaped by conflicting discourses variously prioritising economic development, community livelihoods and environmental conservation (Resosudarmo, 2005). To these themes the REDD+

of calculation, monitoring and reporting of REDD+ activities' performance in reducing and storing green house gas emissions. 
Taskforce has sought to introduce and embed specialised carbon concepts and languages proliferating amongst REDD+ experts internationally. Through the use of scientific terminologies and particular discourses REDD+ is promoted as a form of ecological modernization - combining economic growth opportunities with ecological conservation benefits (Lovell and Liverman, 2010; Gupta et al., 2012; Boer, 2013; Lovell, 2014). Discourses on the green economy and environmental economics for instances, are employed to frame forests as "terrestrial infrastructure for global capital" (Luke, 1999, p. 106). In other words, the discourses frame that it is the interest of Indonesia's forest stakeholders to adopt REDD+ as a mechanism to prevent climate change while at the same time securing economic growth from the forestry sector (eg UNFCCC, 2011; McDermott et al., 2012).

In international REDD+ communities, carbon concepts such as leakage, additionality, and permanence are used to understand, communicate and articulate the behaviour of forest carbon (van Oosterzee, Blignaut and Bradshaw, 2012). In the context of REDD+, leakage is a term used to define the increase in carbon emissions from deforestation that happened outside the REDD+ project boundaries (van Oosterzee, Blignaut and Bradshaw, 2012). Permanence refers to the assurance that the emissions reduction in a REDD+ project will be maintained for the duration of the project (van Oosterzee, Blignaut and Bradshaw, 2012). Meanwhile, additionality denotes the evidence that a REDD+ project has to show the potential of emissions reduction that would not have happened without the implementation of the project (van Oosterzee, Blignaut and Bradshaw, 2012). Such terminologies provide new ways of constructing and valuing land use and types, as evident in the following quote involving a member of one of the Working Groups,

We [the Working Group] pay a lot of attention to peatland due to the high amount of carbon stored, such as those in Central Kalimantan and Riau. Having REDD+ projects on peatland are good for us [Indonesia]... We could argue for the additionality of having these types of projects because otherwise these forests will be opened for plantations. These precious peatlands will be dried and sometimes even burnt to make it easy to plant ... It's a massive problem... [Peatland fires] cause carbon leakage and haze 
pollution... It's not good for our reputation, its not good for our relations with neighbouring countries ... No one will ever believe that carbon coming from REDD+ projects in Indonesia will be permanently stored in the peatland (Interview, Yamadhi, January 2014; emphasis added)

The deployment of technical and scientific concepts and vocabularies, most of which are poorly understood by non-REDD+ forest stakeholders, has become a powerful tool in legitimising and envisioning the program.

The promotion of carbon concepts is particularly apparent in the draft MRV Strategy that was developed under guidance from the REDD+ Taskforce. The MRV Strategy outlines procedures for assessing and guiding sub-national programs or activities at the project level. It provides a level of accountability for carbon buyers knowing that carbon produced in Indonesia is coming through certain verification and validation methods that comply with international standards. In so doing, the MRV strategy functions as a technology to shape the conduct of those involved in a REDD+ project. Those who do not conduct themselves according to carbon rules and concepts are excluded from certified emission reduction certificates and "let die" (Foucault, 1990), while those who do are rewarded with certificates and the potential of financial gains. As an example a member of the Working Group on Funding Instruments explained:

It is necessary to have the principle in place to discourage a sub-national government decision to implement REDD+ in a particular area while giving up neighbouring areas for logging or plantation that will result in carbon leakage which subsequently affects the incentive the sub-national government will receive (Interview, Hersri, September 2013).

Concepts like leakage, additionality and permanence establish particular "truths" about forest carbon, asserting that it can be controlled and calculated, thereby making its management appear achievable and commonsense (Bäckstrand and Lövbrand, 2006). Standards and guidelines create uniformity for carbon across space and time to enable it to be traded through internationally recognised 
mechanisms such as the Verified Carbon Standard ${ }^{6}$ (Government of Indonesia, 2012a).

The Taskforce also created a national social and environmental safeguard document known as PRISAI (Prinsip, Kriteria, Indikator Safeguard Indonesia - Principles, Criteria, Indicators Safeguard Indonesia), outlining a variety of procedural measures being implemented to ensure programs meet social and environmental standards (Satgas REDD+, 2013c). Through the PRISAI, other REDD+ terminologies oriented at governing forest communities are apparent. The terms safeguards and FPIC (Free Prior Informed Consent), for example, position social and environmental concerns as resolvable through the application of a set of processes and procedures. FPIC is a participation and consultation technology built to govern both REDD+ developers' and forest communities' mechanisms to produce consent and express grievance. Safeguards, meanwhile, are a set of normative principles that have to be adopted by REDD+ developers to minimize the negative impacts REDD+ projects may have on community and environment. While FPIC and safeguards did not first emerge through REDD+, they have become vital to the legitimacy of the program.

From a governmentality perspective, the incorporation of new (and old) terms, oriented at governing the behaviour of carbon and people living in carbon-rich landscapes, are mechanisms through which REDD+ proponents seek to facilitate the "conduct of conduct" (Foucault, 1991a). They provide norms and knowledges through which human and non-human (forests and carbon) behaviours can be calculated, valued and, if necessary, reoriented. This new way of talking about and constructing forests is aided by high-resolution satellite images, computer modelling, and sophisticated knowledge on carbon accounting (Gupta et al., 2012; Stephan, 2012). As a consequence attention naturally flows to the technical issues

\footnotetext{
${ }^{6}$ The Verified Carbon Standard (VCS) is a voluntary carbon standardization mechanism (see www.v-c-s.org). Voluntary means this mechanism is built outside the formal and binding scenario of the UNFCCC. A particular REDD+ project can adopt VCS as their strategy and in doing so the project has to follow the rules and regulations from VCS. After a complex verification and validation processes performed by the VCS experts to quantify the amount of carbon reduced, a project can be issued Verified Carbon Units (VCUs). VCUs represent the removal of one ton of carbon dioxide equivalent $\left(\mathrm{CO}_{2} \mathrm{e}\right)$ (www.v-c-s.org, 2015). The VCUs can be traded as carbon credits in the voluntary carbon market.
} 
such terminologies highlight. Hence, in the following example an Indonesian academic concentrates on the difficulties posed by additionality:

Papua and East Kalimantan provinces each has a very different historical emission, with the latter having high planned and unplanned deforestation rates compared to the former. If we are using historical reference to define the baseline then how could we justify the additionality of having REDD+ project in Papua compared to East Kalimantan, as some buyers will think that it is a false investment to make in an area that had no real danger of deforestation? (Interview, Hartadi, February 2014; emphasis added)

In this example the introduction of carbon terminologies provides a means to discuss and frame forest management in ways that are far removed from biodiversity, livelihood and economic concerns that would previously have been used to consider deforestation (Boer, 2013). As such REDD+ is adding new dimensions to the already complicated politics of Indonesia's forests. Particular scientific and economic claims about carbon are being authorised and promoted in place of, or at least in competition with, other ways of knowing and being. The prioritisation of such languages, favours some over others, with REDD+ being driven by specialist technical communities (Aicher, 2014). It benefits those national-scale actors closely connected to the program, while marginalising more distant forest communities who, nevertheless, will be deeply affected by REDD+ decisions.

Prioritising forests as carbon sinks has been contested, meeting resistance from a variety of stakeholders including those with vested interests in forest conversion. A high ranking palm oil plantation representative, for example, reflects broader discontent when refuting the Taskforce's claim of there being a sustainable growth opportunity provided by REDD+, claiming,

REDD+ is a losing battle for Indonesia's economic and energy sovereignty ... the government has to realise this reality and start clearing the path for real economic development that brings more money and provides thousands of job opportunities (Interview, Januarto, July 2013). 
This argument is echoed by the MOA, which highlights the negative impacts the forest moratorium policy implementation has for economic growth in the agriculture sector, since the policy has closed opportunities to open new palm oil plantations on peatland (Astuti, 2013).

While those interested in forest conversion question the economic benefits of the program, several NGOs have also resisted the carbonisation of Indonesia's forests, for different reasons. One group opts for critical resistance toward the neoliberal characteristics of REDD+ by framing it as a new "green colonialism". An activist expresses her disagreement to REDD+ by saying that,

[REDD+ is a] false solution for ecological crises offered by developed countries ... it is just another form of colonialism hiding behind the intention to save the global climate and Indonesia's forests. If they [developed countries] really care about the environment, they should have stopped consuming so much fossil fuels (Interview, Dewanti, July 2013).

Civil society-led anti-REDD + arguments are now well established amongst some global environmental and Indigenous networks (see Boas, 2011) and represented most visibly by WALHI (Friends of the Earth Indonesia - Wahana Lingkungan Hidup) in Indonesia. A second group opts for critical engagement with REDD+, although emphasising the "co-benefits" regarding improved Indigenous rights recognition and forest governance rather than carbon. Proponents of this view believe REDD+ has "room for manoeuvre" on social and environmental concerns:

It's the time for NGOs to be politically strategic on what they do. The "wind direction" has changed and we [civil society] will be left behind if we are not adapting to the new reality that the government and the private sector are no longer merely our enemies. In my opinion, we could achieve more if we could work together ... we want them [the government and the private sector] to change their practices and be more concern to the environment, forest communities and Indigenous people ... for me REDD+ is this opportunity. 
Through REDD+ I see the possibility to force the government and the private sector to be accountable for social and climate justice agenda (Interview, Marina, May 2013).

The latter argument, which is the predominant position of national NGOs, has influenced the narratives emerging from the Taskforce, which saw NGOs a source of political support and alliance. Hence, the phrase "Beyond Carbon, More than Forest" was adopted by the Taskforce at the UNFCCC 2012 in Doha in response to civil society concerns.

The "Beyond Carbon" strategy was well received by the NGOs, which see it as a step towards broader acknowledgement of their core social and environmental concerns. As one interviewee argued, "the language framing of "Beyond Carbon" is the Taskforce manoeuvre to support NGOs struggles" (Interview, Jodi, May 2013). This is through the adoption of a series of strategies including participatory approaches, addressing environmental crimes, and reviewing illegal forest licences (Government of Indonesia, 2012b; Lal, 2012). Kuntoro Mangkusubroto, head of the Taskforce, explains;

We are leaving the old paradigm of having trees cut and getting revenues from this, and entering a new era: the trees will stand, and at the same time revenues are received and people's welfare is improved, that to me is moving beyond carbon ... that's the essence of REDD+ (Lal, 2012, p. 3).

Despite the "Beyond Carbon" framing, carbon rationalities are still central to the approach, as emissions reductions ultimately finance the improvements. However the narrative has moved beyond purely financial incentives to associate REDD+ more closely with social and environmental justice, as evident in the images frequently used in the Taskforce's presentations (eg Figure 5.1). Mainstreaming these latter concerns has made REDD+ more acceptable to civil society: REDD+ shifts from an ecological modernisation framing to one that incorporates the ideals of civic environmentalism (Bäckstrand and Lövbrand, 2006), where the emphasis 
shifts from prioritising carbon towards a greater focus on alleviating crises of forest governance, poverty and biodiversity.
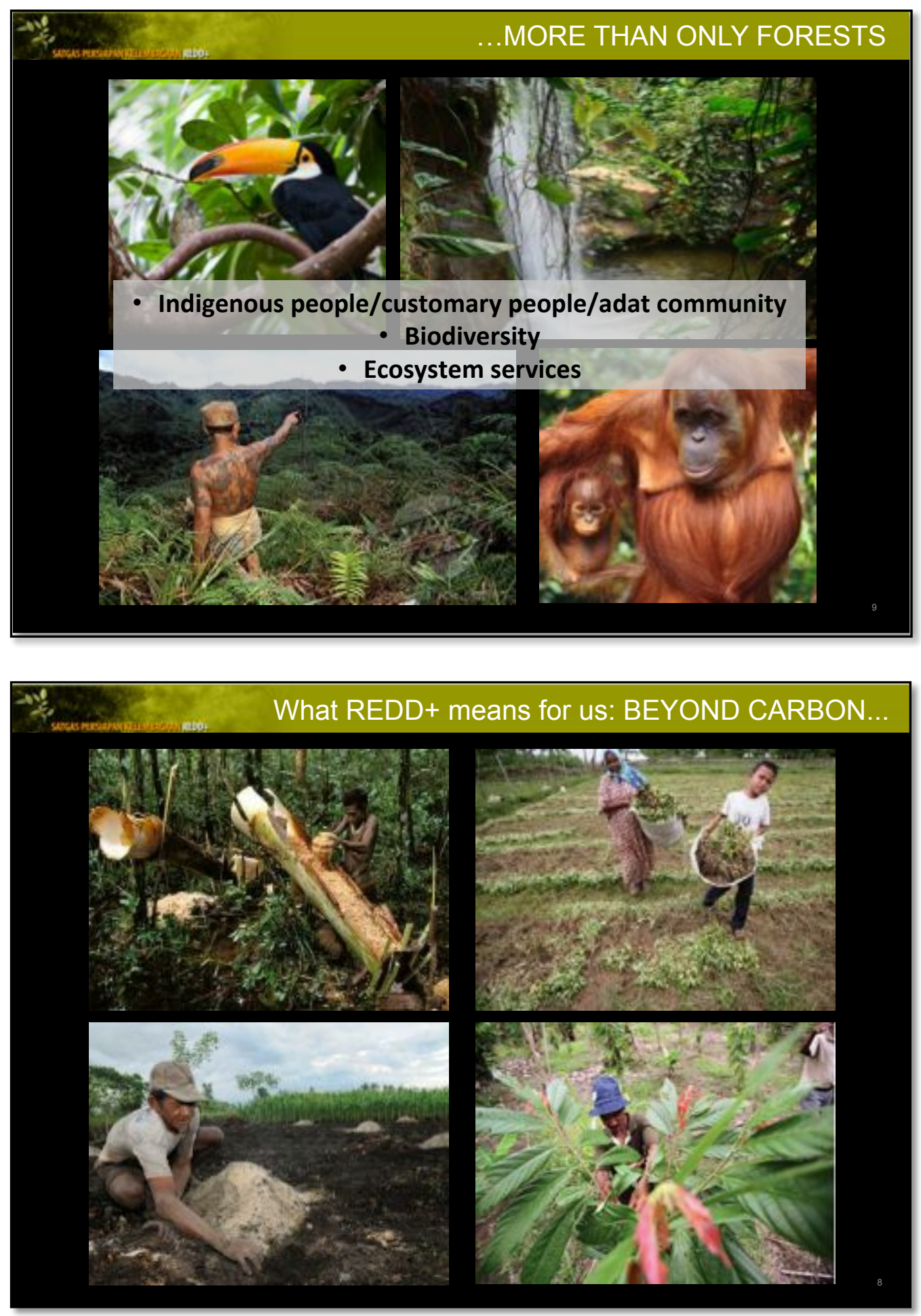

Figure 5.1 Images represent REDD+ "Beyond Carbon" approach (Mangkusubroto, 2013) 
The attempts of the REDD+ Taskforce to promote carbon rationalities in Indonesia are incomplete, as REDD+ is still widely debated and forest governance remains a contested space. However through governmental technologies that promote REDD+ terminologies and concepts in policies, reports and consultations, carbon rationalities are becoming more acceptable and mainstream. So too are discourses of social and environmental justice, which through the participatory strategies of NGOs (discussed further below), are becoming more visible and apparent in the REDD+ Strategy and Taskforce activities.

\subsubsection{Visualising Forest Carbon}

The Taskforce's efforts to normalise carbon rationalities through introducing specialist languages and concepts were accompanied by mapping practices oriented at making carbon visible. Maps that show the carbon density of forests were frequently used in Taskforce presentations to highlight narratives regarding REDD+ opportunities, potentials, and threats (eg Figure 5.2). The maps inform stakeholders of the forest types that store high amounts of carbon and can therefore be made profitable through REDD+. In some cases carbon maps are overlaid with other types of spatial information, such as mining concessions in a particular province, as shown in a map produced by the UN-REDD Program Indonesia in Central Sulawesi (Figure 5.3) (Blyth et al., 2012). In this map overlapping areas of high carbon density and mining concessions can be used as basic information to discuss the economic trade offs between REDD+ and mining interests. 


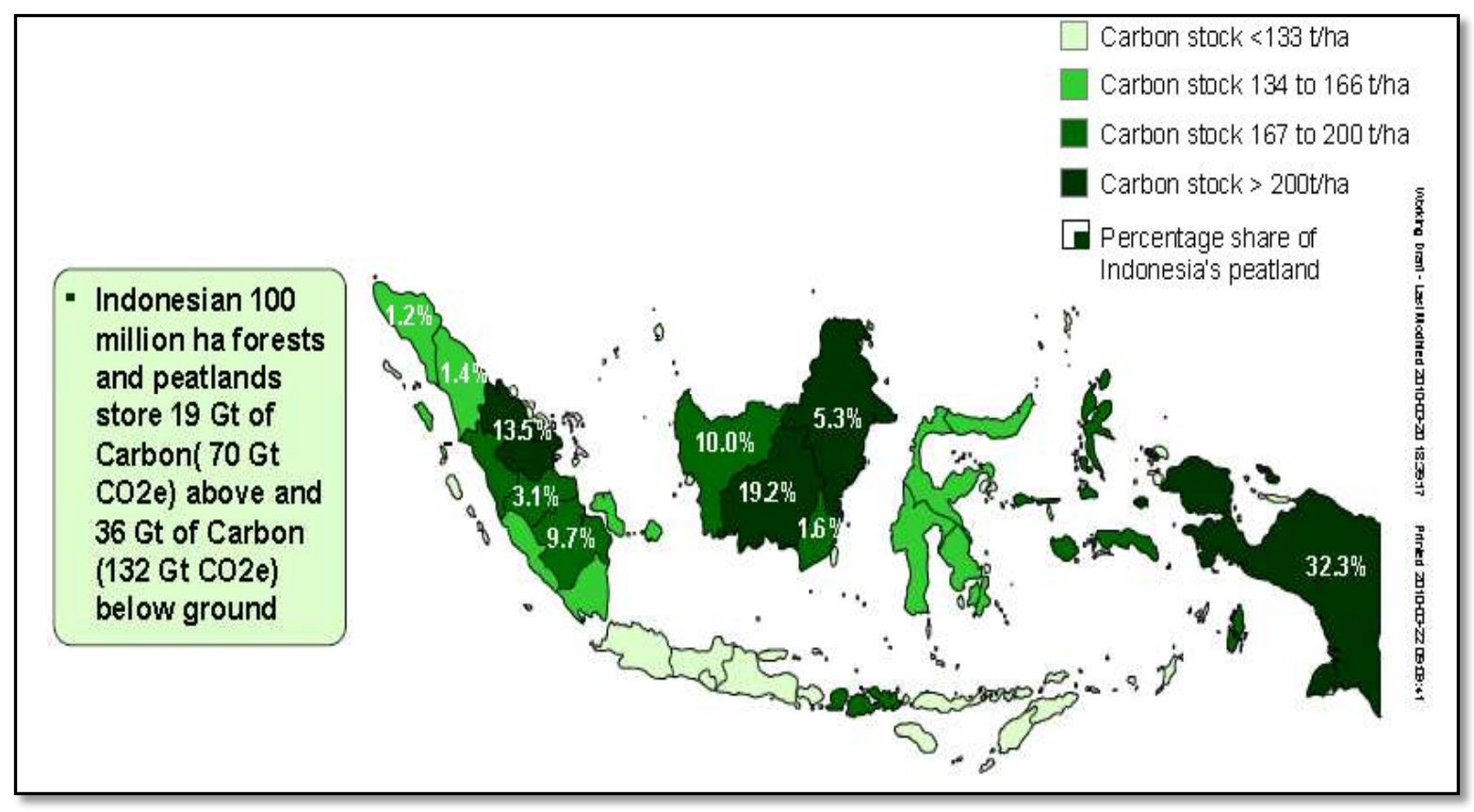

Figure 5.2 Map of Indonesian forest carbon stock

(IFCA, 2008; cited in Masripatin, 2010) 


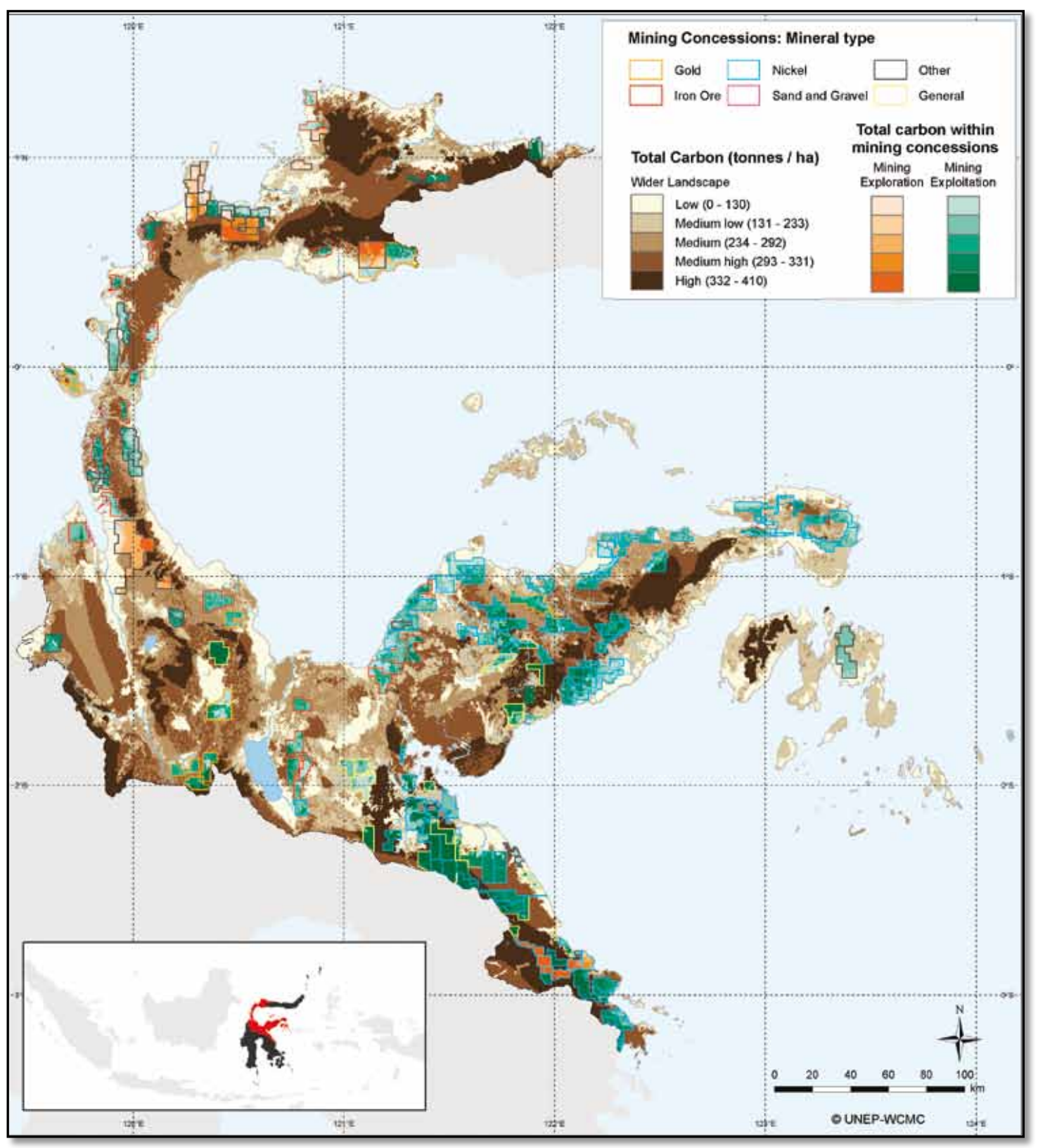

Figure 5.3 Mining concessions in relation to total carbon in Central Sulawesi (Blyth et al., 2012)

Carbon maps function as important visualisation technologies to steer forest policy development and decision-making processes towards REDD+ goals. In an interview, a government official highlights her experience regarding the way she communicates the urgency of the REDD+ programme to her intended audience, 
Since COP 13 in Bali, it is common to discuss sustainable development and green economy using a map of Indonesia that is overlaid with a map of carbon potential stored in Indonesia's forests. The audiences are usually quick to make a connection between the topic that I intended to speak with the presentation slide... I think this map speaks for itself (Interview, Randy, February 2014)

Carbon maps serve as “almost everyday images” (O’Neill and Smith, 2014, p. 79) in the discussion of climate mitigation and forest governance. In visualizing a certain element within the forest they frame a particular way of seeing. The carbon map hides the immense complexity and uncertainties within carbon measurement and accounting (Gibbs et al., 2007; Asner, 2009), and renders an intangible molecule visible and real, while potentially obscuring other socio-ecological data and ways of seeing. In the maps above, for example, carbon is clearly prioritised over other forest interests in biodiversity, livelihoods and timber. Mapping technologies help in drawing boundaries around what readers should consider normal and important, being essential in visualizing carbon as politically, economically, and scientifically acceptable and governable (O’Neill and Smith, 2014).

In 2011, reflecting the country's REDD+ ambitions, a Presidential Decree imposed a moratorium on new licences for the development of primary forest and peatland. The promotion of peatland to a conservation status akin to forests, despite generally being much less biodiverse, is a direct reflection of the high amount of carbon stored in these areas, and reflects the changing criteria being used to value different socioecological systems. However attempts to map primary forest and peatland has proved difficult, with different actors referring to peatlands in different ways (Caldecott et al., 2013). Three different "official/authoritative definitions" of peat have been issued by three different ministries, i.e. the MOF, MOA, and MOE. Consequently, each of the ministries has also released different thematic maps of peatland, reflecting their own visualisation strategies and priorities.

In response the Taskforce has engaged with a national donor-funded strategy known as One Map that seeks to provide a single authoritative map to guide all land 
use decisions in Indonesia (see Chapter 6). To seek consensus on One Map in regards to peatlands a series of expert meetings were held by the Taskforce's Working Group on the Moratorium. A member of the Working Group explains that

Through the One Map processes we will have one source of spatial information. The accuracy of which will not be doubted by any actors. If we could control one variable of the spatial governance debates in Indonesia, including the definition of peatland, then the rest of the debates will voluntarily follow the controlled variable (Interview, Suwardiyanto, July 2013).

One Map then seeks to establish "one truth" about the amount of carbon stored in different land types upon which the practices of REDD+ governance can be built. Through this technology, the outcomes of which are accessible through public webportals $^{7}$, the carbon values of different land types becomes standardised and mainstreamed within land use planning. The technology thereby makes carbon visible to authorities at all levels, requiring them to consider carbon, and REDD+ more generally, in their land use decisions. In the process the carbon values calculated and embedded into One Map are intended to influence the conduct and decisions of land use authorities and, as a consequence, govern human - forest interactions. Those who may value forests for other reasons, such as forest communities, or developers, are invisible, and potentially disempowered, by these technologies.

In parallel, however, AMAN took the opportunity to show the importance of recognizing and protecting Indigenous forests by overlaying the indicative map of Indigenous territories with map of forest areas (Figure 5.4). By using a map of potential forests and present them as significant carbon sinks, AMAN renders visible the Indigenous territories and influenced the tone of REDD+ discourse in Indonesia to be more centred on Indigenous tenure rights. Furthermore, by employing the slogan "No Rights - No REDD+", AMAN steers the way REDD+ policies and programs

\footnotetext{
${ }^{7} \mathrm{~A}$ centralized database of spatial information is made publicly available in portal.inasdi.or.id. The website Ina-Geoportal is part of the One Map Initiative.
} 
are being made in an effort to attract financial and political support for their agenda (Howell, 2014). Meanwhile, for the Taskforce, AMAN's endorsement to REDD+ implementation is regarded as a strong legitimacy and sign of acceptance (see Chapter Seven). AMAN's attempt to produce forests map shows how the Taskforce's governmental strategies to normalize and visualize carbon have been incorporated by other forest stakeholders. It also demonstrates elements of agency on the part of AMAN who is engaging with governmental technologies to seek progressive goals using carbon rationalities to highlight the relationships between Indigenous communities and their land. In this way REDD+ governmental technologies can be subverted by NGOs to produce not-quite-neoliberal strategies that facilitate more progressive possibilities (Anthias and Radcliffe, 2015; de Freitas, Marston and Bakker, 2015).

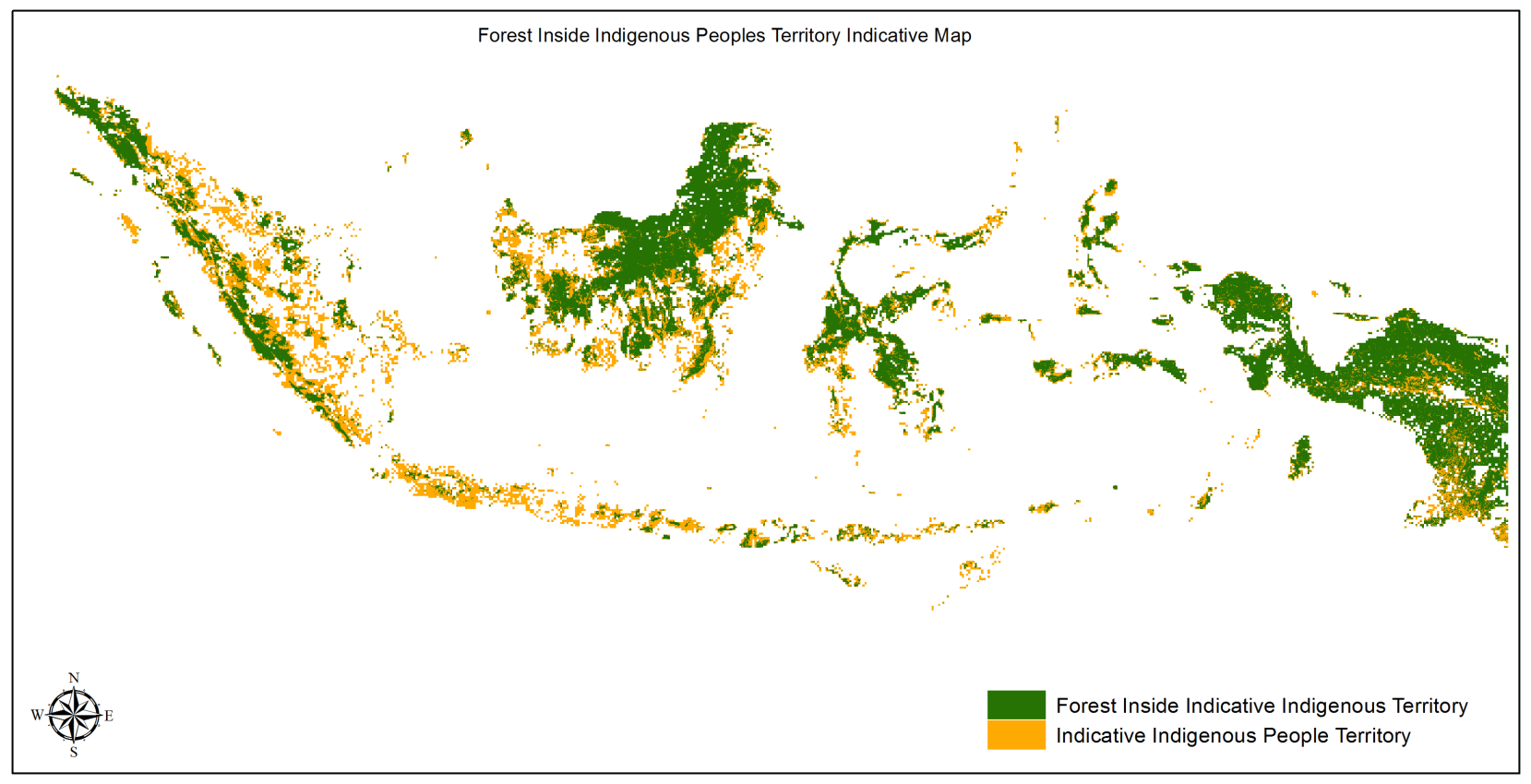

Figure 5.4 Overlay of Indigenous territories and forest areas

(AMAN, 2014) 


\subsubsection{Engaging Forest Carbon}

A further governmental technology applied by the Taskforce sought to produce proREDD+ subjectivities through the provision of participative technologies. These technologies are a type of disciplinary strategy, which rather than providing financial incentives to shape behaviour as is common under neo-liberal governmentalities, sought consensus through engagement and agreement on shared norms and principles (see Fletcher, 2010). Participation is considered an important component of REDD+ governance, with researchers calling for more collaborative REDD+ policy making processes between public authorities, civil societies and forest communities. Forsyth (2009) argues equal participation of all REDD+ stakeholders in the policy-making processes and project implementation is vital for good governance. Donors, such as the Norwegian Agency for Development Cooperation (NORAD), and civil society actors also call for inclusive policy making processes that will open windows of opportunities for public monitoring. The inclusive approaches adopted by the Taskforce include, among other things, public consultations, focus group discussions, working groups, and partnerships that were conducted throughout the readiness phase (Satgas REDD+, 2012).

Technologies of participation and consultation assembled multiple stakeholders with diverse interests to reach consensus on particular political decisions. Examples include the Working Groups described earlier, one of which conducted a series of public consultations to help develop the REDD+ National Strategy. A government official involved in the development of the strategy explains that:

The first version of the REDD+ National Strategy produced under the coordination of Ministry of Development Planning was deemed as too critical toward the MOF, by putting almost all the blame of the ministry's weak forest governance as the underlying cause of deforestation and forest degradation in Indonesia. The second version developed under the coordination of the REDD+ Taskforce and has been through a series of public consultations and government meetings was seen as a product that will less likely offend any particular institution (Interview, Dandi, July 2013). 
Activists described the 'countless' meetings and dialogues held within in each of the Working Groups for the purpose of seeking agreement on policy drafts being discussed. The internal processes were complemented with national and subnational public consultation processes and focus group discussions with multiple REDD+ stakeholders (Satgas REDD+, 2012, 2013a). As such, the technologies enabled the Taskforce to introduce REDD+ concepts and rationalities to a broader group of forest stakeholders while at the same time justify the policy or decision made as a product of democratic practices. Several environmental activists note during interviews that they considered the Taskforce to have developed good mechanisms for successfully engaging civil society, particularly through the establishment of Working Groups. One of the interviewees highlights the processes, saying,

Despite still lacking transparency for the Taskforce's high level political decision making, NGOs were present in almost all aspects of REDD+ policy making within the Working Groups. These have been so far my best experience of being engaged in the forest related policy making processes (Interview, Taksaka, July 2013)

Another environmental activist interviewed points out the fact that his "trusted colleagues" were part of the Working Groups and that he has no doubt about their commitment to fight for social and environmental justice concerns within these structures (Interview, Hasan, May 2013). However, as the two quotes highlight, there are still transparency issues particularly in the higher level decision making processes. In addition, the absence of the parliament's involvement in the REDD+ policy making together with the issues regarding the unclear legitimacy of NGOs representation has been criticised as undermining democratic process and violating REDD+ procedural justice (see eg Luttrell et al., 2012; Sikor, 2013).

There can be little doubt though that this approach has provided civil society access to decision-making processes involving REDD+, and potentially influencing future forest management, at a level that was previously out of reach. Interviews suggest 
that Working Groups provided opportunities for vigorous discussions over policy and principles that led to the "Beyond Carbon" narrative. However participatory technologies can also set the terms of the debate and frame the structures through which issues should be resolved. Mirroring what Li (2007a, p. 234) observed in a different context, stakeholders tended to engage in these processes through "the forms of maps, diagrams, charts or other forms of templates" supplied by those organising the participatory activities. As such, participatory technologies can be used to render the political complexities of REDD+ actors' positions and concerns intelligible and calculable, as "only then can specific intervention be devised" (Li, 2007c, p. 6; Boer, 2013). While it is not always the case, the content of the templates were usually prepared according to the interest best suited to the Taskforce's agenda, narrowing the scope of debates by prioritising carbon for example, whilst (quite possibly inadvertently) marginalising other values and claims.

Within the Working Groups, civil society representatives were repositioned as expert advisers rather than social or environmental activists, and given authority and responsibility in shaping and legitimising REDD+ policies and infrastructures. According to the interviews this new subjectivity sometimes placed representatives in awkward situations, particularly when they represented the REDD+ Taskforce and sought to engage civil society colleagues in a process of policy or project negotiation. One of the activists interviewed noted his experience saying,

Sometimes we get caught in a tense discussion process, as we cannot reach an agreement. These tensions are not only found in the formal discussion in the meeting rooms, but also in the social media, such as my Facebook page. When there is a controversial policy made by the Taskforce, it is common for my fellow activists to question the Taskforce action by posting comments in my Facebook page to ask for my explanation. Otherwise it's been a good experience, as I and them are mostly agreed on basic principles of advancing Indonesia's forest governance reform (Interview, Jodi, May 2013).

Similar awkwardness was related by activists who were positioned "outside" of the bureaucratic system, who highlighted the difficulties in critiquing the Taskforce as 
they were "confronted by their friends and not the real government bureaucrats" (Interview, Hartono, May 2013). In addition many activists participating in the Working Groups reported that it made them less critical of the Taskforce and REDD+ in general. An activist that was a member of the Working Group on REDD+ National Strategy explained,

After knowing the complexity of bureaucracy and the politics involved in the REDD+ policy making processes, it is difficult for me to accuse the Taskforce, especially Kuntoro, for not doing his best. If I were in his position I wouldn't be able to achieve what he has achieved so far (Interview, Jodi, May 2013).

A subtle shift was evident amongst some members of the Working Groups who were beginning to adopt more formal expert subjectivities over activist ones. These members took on consultancy roles working under professional contracts with the Taskforce, rather than working as activists representing their organisations. This was evident in the conduct, vocabularies used, intonation, and sometimes the agenda or interest that was prioritised during policy or project debates and negotiations. One activist who has adopted an expert subjectivity explained,

It is sometimes unavoidable to lower my expectation during policy negotiations. Not only did I lower my expectation, but also the tone of my voice... I realize that I speak not only to my activist colleagues, but also to other peoples who are coming from different backgrounds with different agendas and interests... This is what I mean as a cost for negotiating the space in order to reach consensus among diverse interests (Interview, Josyana, March 2014).

Whereas shifting subjectivities were present amongst some civil society representatives in the Working Groups, such shifts were less apparent amongst government officials. Those who participated in the Working Groups did so as individuals rather than representatives and there was little evidence that any shift in their personal stance on REDD+ was of influence within their Ministries. Three consecutive Taskforce reports to the President cited this as a problem in 
implementing political decisions agreed to by the Working Groups and to be executed within the Ministries or state agencies (Satgas REDD+, 2012, 2013a). Rather than buying into the Taskforce's vision, some Ministries appear to be actively resisting the carbonisation of forests by questioning the Taskforce's authority and capacity, despite the participatory approach adopted. The most apparent example is the initiative to develop a REDD+ registry and safeguard information system initiated by MOF, in parallel and in conflict with the development of the registry and safeguard mechanism proposed by the Taskforce. Another example is the difference in position between the Taskforce and MOF concerning the implementation of the first forest moratorium policy, as the latter chose to question the negative impact of the policy for economic development. Despite having overlapping interactions in various meetings, the two institutions seem to neglect each other's initiatives and positions. Consequently, confusion has been caused among REDD+ actors, especially project developers, regarding whose mechanisms they should follow. MOF's resistance towards the initiatives delivered by the Taskforce is a good example of the limit to the practice of government the Taskforce has tried to exercise (Li, 2007c).

\subsection{Transforming Forest Politics?}

The REDD+ Taskforce had an unenviable task - to change the political ecology driving Indonesia's high rate of forest destruction. With contested legitimacy it sought to mainstream carbon rationalities within hotly contested forest landscapes. It has made progress in building awareness about carbon, with most forest stakeholders at the national scale now at least being aware of REDD+ and the potential carbon economies involved (Lillegraven and Sombolinggi, 2014). Drawing on the notion of governmentality and based on extended qualitative research, this chapter has argued that the REDD+ Taskforce drew on three key strategies in its attempts to mainstream carbon rationalities amongst forest stakeholders. These involved the adoption and promotion of carbon languages and concepts; mapping strategies that make carbon visible and governable; and through participative technologies that engaged stakeholders in decision-making processes and consultation. Through these approaches a new episteme is evolving based on the carbonization of Indonesia's forests. 
The consequences of these strategies are yet to become fully known - indeed carbon is simply the latest ingredient to be thrown into the heated arena of Indonesia's forest politics. At the time of writing, for example, some five years after the Taskforce was formed, and after many millions of dollars have been invested, only two REDD+ projects located in Indonesia has been successful in selling carbon credits. Yet some things have changed. The governmental technologies applied have helped REDD+ stakeholders visualize carbon as a governable entity. The specialist communities of scientists, economists and activists who produce REDD+ maps, concepts and approaches are becoming empowered, and those that can engage with these discourses have new opportunities to position themselves effectively in a REDD+ regime. Those that do not, including the thousands of forest communities across Indonesia that are not being facilitated by organization such as AMAN, risk marginalisation, as REDD+ decisions may be made that affect their interests without their knowledge or understanding.

New REDD+ savvy public-private-community sector alliances have formed that combine diverse interests from saving tropical rainforests, preventing global warming, protecting local livelihoods, and pursuing profit from carbon economies. New rules, roles and responsibilities are emerging, including the potential for greater dialogue and alliances between civil society groups and forest authorities. While this increases the likelihood that issues of social and environmental justice will be addressed in forest governance it also raises troubling questions about the future role of civil society organisations and representatives if they become incorporated into governmental processes rather than independent from them. A key challenge will be to ensure the non-carbon interests of forest communities play an important role in REDD+ futures, and their struggles are recognised and engaged, rather than reduced to a set of technical procedures.

Carbon rationalities are becoming more common and understood, yet they are far from dominant in Indonesia's forest politics. Some forest stakeholders are opposed to carbon trading and seek changes to forest governance through other mechanisms. Other stakeholders are profiting the existing political ecology of forest destruction 
and are resistant to carbon rationalities. Clearly forest governance based on managing carbon will legitimise some actors and forms of expertise and knowledge over others. The REDD+ Agency that replaced the Taskforce as the authority implementing REDD+ in Indonesia faces a bumpy road ahead as will be discussed in the next section. It will need to harness a different array of governmental tactics to bring competing agencies, and most importantly, vested private sector interests, into REDD+ visions of human - forest relationships.

\subsection{The Short Life of the REDD+ Agency}

In September 2013, President Yudhoyono finally issued Presidential Regulation Number 62/2013 that cleared the way for the establishment of a more permanent REDD+ Agency. The formation of the new Agency replaced the ad-hoc role of the Taskforce and was expected to provide a stronger foundation for the implementation of REDD+. The formation of the Agency took more than a year since the Taskforce submitted a concept report to President on the proposed role and form of the Agency. Reflecting on the long political process leading to the formation of the Agency, one informant from the REDD+ Agency stated in an interview,

Everything is political in this country. There will be a lot of stakeholders that will be disadvantaged by the formation of the new agency. It's a tug of war process - the President has to make sure that everyone [the ministries affected] is happy with the decision. We had submitted a proposal. However, to what extent the content of the proposal will be accommodated is really in the hand of the President and the political talks between his ministers (Interview, Bandana, June 2013).

This statement alludes to the politics that took place behind closed doors. A similar process was seen during the formulation of the forest moratorium policy (discussed in Chapter 6), suggesting high level decision making is hidden from view. Meanwhile, commenting on the President Yudhoyono's decision, Hadi Daryanto, the Forestry Ministry's General Secretary articulated his resentment toward the establishment of the Agency by highlighting the minimal role the Agency had and its lack of authority, saying, 
However, the REDD+ council [Agency] will not be able to take any actions. The council only has the power to report on emissions reduction projects and any program irregularities to the related ministries. It is then up to the appropriate ministry to take action... It's merely an independent committee that links institutions so that REDD+ implementation can be integrated and free from overlap among ministries and institutions (The Jakarta Post, 2015)

There was a mixed response from the NGO sector. In a bid to strengthen the REDD+ Agency's authority, a coalition of activists called Civil Society Coalition to Save Indonesian Forests and Global Climate issued a statement criticising the Presidential Regulation, by stating that,

The Coalition has reminded government that transitional institutions will not be able to change the corrupt system unless coupled with a fundamental change in the status quo institutions that have been trying hard to ward off reform. In this case, the REDD+ Agency, whose hands have been tied from the start, is in all probabilities left with only minor and insignificant roles when faced with established forces such as the Ministry of Forestry, Mining, and Agriculture that are supposed to be the main target institutions in emissions reduction efforts (taken from fwi.or.id, 2013).

This support from the civil society coalition for REDD+ programs demonstrates a level of success in mainstreaming REDD+ amongst civil society. This is despite, and perhaps partly because of, limited political support from other government ministries, particularly the MOF.

The establishment of the Agency has drawn much appreciation. Dubbed the first of its kind, the Agency was expected to advance Indonesia's forest governance reform despite its limited authority. To further normalize the slogan "Beyond Carbon, More than Forest", the Agency developed ten imperative programs as the Agency's priorities during its planned three year timeline from 2014 - 2016. These were: 
1. Moratorium monitoring and One Map Policy Implementation

2. Forest licensing management

3. Law enforcement

4. Indigenous mapping

5. Forest fires control and management

6. Green village

7. Green school

8. Support for integrated spatial planning

9. Conflict resolution road map

10. Strategic program for national park and conservation forest

The Agency's strategies to further mainstream REDD+ in Indonesia extended the three governmental techniques described in the previous sections. To communicate the REDD+ vision of "Beyond Carbon", the Agency employed two emerging concepts in the forest management approach known as the "landscape approach" and "jurisdictional approach" to highlight the cross sectoral nature of the program. The landscape approach aimed to govern the socio-nature relations between all types of land uses (see eg Minnemeyer, Laestadius and Potapov, 2009; DeFries and Rosenzweig, 2010; Sayer et al., 2013). Meanwhile the concept of jurisdictional approach was employed by the Agency to formulate the right scale of REDD+ implementation in the decentralized forest governance in Indonesia (see eg Nepstad, Boyd, et al., 2013; Nepstad, Irawan, et al., 2013; Ashwin et al., 2015). These two concepts provided new languages and concepts for REDD+ implementation.

In rendering REDD+ visible as a governmental strategy, the Agency actively led several initiatives, such as OMI and the management of forest fires. These attempts are aimed at strengthening the visibility of the REDD+ program in Indonesia and show the importance of REDD+ Agency as an institution. In an interview with a REDD+ Agency official, he emphasized the importance of building a track record to ensure the continuation of the Agency under the new regime:

We need to deliver tangible results in such a short time to convince the upcoming elected president that this Agency is indeed needed in the 
configuration of forest governance. We chose to deliver low hanging fruits programs by engaging as many district governments as possible ... and therefore developed a strong hold on the ground with real impacts (Interview, Erwinda, March 2014).

As such the Agency sought to mainstream REDD+ across geographic scales. Efforts were undertaken in 71 districts in 11 provinces that subsequently became populations subjected to REDD+ governmental tactics. Memorandums of Understanding (MoUs) were signed between the Agency and the district governments. The Agency also built a stronger relation with AMAN and other environmental organizations by granting financial support for the NGOs' programs that were seen to align with the Agency's interests and recruiting experts that were mostly from environmental and other social NGOs for day-to-day operations. The recruitment of activists was considered as an example of it being a less bureaucratic government agency.

However, despite what some of the NGOs saw as a success, approximately a year after the establishment of the Agency in January 2015, the new regime under President Joko Widodo decided to merge the Agency under the newly established Ministry of Environment and Forestry (MOEF) ${ }^{8}$. The decision was made after a tense political negotiation between the Agency and the President's secretarial minister. An interview with a member of the President's special staff revealed that the pressure from what was previously the Ministry of Forestry had led to the secretarial minister deciding in favour of the dissolution of the Agency which was issued as President Regulation Number 16/2015. The Minister stated in the media that the dissolution was driven by the need to avoid overlapping of authorities between the Agency and the newly established MOEF. This dissolution shows how forest politics in Indonesia is very dynamic and is very fragile in the face of political changes.

\footnotetext{
${ }^{8}$ Ministry of Environment and Forestry (MOEF) is the newly formed government agency under President Jokowi. The ministry is the result of merger between four government bodies: the Ministry of Forestry, the Ministry of Environment, the REDD+ Agency, and the National Council on Climate Change. The new ministry established a new Directorate General on Climate Change to fill the vacuum left by the REDD+ Agency and the National Council on Climate Change.
} 
The dissolution was met with a mixed response. One of AMAN's staff expressed disappointment with the President's decision by stating,

We are worried that this decision to merge the REDD+ Agency under the Ministry of Forestry and environment will undermine the effort to advance forest governance reform. We see the Ministry to be part of the status quo that wont be interested to the agenda that the Agency has developed. As we have been collaborating closely with the Agency, this decision will definitely affect our own advocacy agenda (Interview, Hersri, January 2015).

The above statement illustrates the wide support that the Agency had received from the civil society organizations. In an interview, an activist stated that the support developed out of the transformation that the REDD+ program had delivered in the last three years in advancing Indigenous rights discourses and national debates on forest governance. It is uncertain that the agenda for forest governance reform will be continued under the new President - and beyond the scope of this PhD research to investigate the early impacts of the President's decision. A REDD+ Agency official, however, warned in an interview about the possibility of hindering the progress of REDD+ implementation, saying:

What I can conclude is that the President's Regulation [No 16/2015] has violated the LoI and will potentially hamper the progress of REDD+ implementation. In a year, there have been more than 8 provinces that signed the MoU of REDD+ implementation and also multiple NGOs currently executing our ten imperative programs. This decision will definitely obstruct the progress that we have achieved. We are afraid that this is actually a step back for forest reform (Interview, Kuswanto, January 2015).

The President's Regulation however also met with strong support from WALHI and some governmental ministries. In an interview, a government official from the Ministry of Development Planning expressed his support for the decision by citing "the need to address the forest reform head on through its own authoritative institution as the best way to strengthen the currently weak and corrupt ministry 
from the inside" (Interview, Andika, January 2015). Efficiency is another reason often cited by actors supporting the President's Regulation as having two governmental institutions responsible for forest carbon may make governance more, rather than less, messy. The existing political ecology in Indonesia appears to be resisting the governmental strategies of the REDD+ assemblage.

\subsection{Conclusion}

This chapter has sought to answer research objective 1(a), focusing on the case study on the REDD+ Taskforce. I have detailed three governmental technologies produced and applied by the Taskforce and their effects on the transformation of forest politics in Indonesia. The Taskforce has introduced REDD+ as a strategy for forest governance reform rather than merely a carbon offset mechanism. It has done so through the adoption of the "Beyond Carbon, More than Forest" rationality and governmental strategies based on the adoption of scientific carbon terminologies, visualization techniques, and participatory mechanisms.

The chapter has also examined the production of pro-REDD+ subjectivities emerging amongst activists who are closely involved in the work of the REDD+ Taskforce. Activists have become closely aligned with parts of the government system and perhaps risk being subordinated and co-opted. Others remain conscious of and cautious about the neoliberal rationality embedded in the program, while participating in ways oriented at advancing environmental and Indigenous interests. For those who chose to engage with REDD+, they have become more in favour of the implementation of the program and see the political space that could be created to pursue progressive possibilities. The next chapter will further discuss the possibilities for the subversion of REDD+ governmental technologies in pursuing environmental and social justice ends through the examination of OMI. 


\section{Case Study Two The One Map Initiative: Producing “Governable Spaces” for Forest Reform?}

\subsection{Introduction}

In the previous chapter I discussed the technologies of government applied by the REDD+ Taskforce to normalize carbon rationalities. This chapter extends this discussion by focussing on a set of governmental techniques that REDD+ proponents are adopting to address the messiness of forestland governance through OMI. To answer research objective 1(b) the chapter focuses on OMI that is the second case study that underpin this empirical research. I focus on three aspects of OMI: the forest moratorium; One Database of forest licensing; and a new common standard in participative mapping. The findings show that the initiative has created new opportunities and constraints for forest reform. New disciplinary and participatory technologies have emerged that have created political spaces for activists to promote social and environmental justice concerns. However the chapter also shows tensions for forest stakeholders between engaging in the new opportunities of the green economy and the risk of having political issues rendered technical.

The chapter begins with the discussion on the production of governable spaces for REDD+ implementation as the main rationality driving the active engagement of REDD+ proponents in OMI. The chapter then focuses on three key OMI technologies oriented at making forest space more governable - the forest moratorium, One Database and One Standard. The chapter completes with a conclusion. 


\subsection{The Production of "Governable Spaces" for REDD+ Implementation}

"Putting forests at the heart of a green economy" was the slogan of a high level dinner hosted by the Indonesian REDD+ Agency at the $20^{\text {th }}$ UNFCCC in Peru, in December 2014. At the event, Heru Prasetyo, the Head of the REDD+ Agency, vowed to make REDD+ a reality by the end of 2016 (Zwick, 2014). He argued that the REDD+ Agency has delivered the required institutional and governance reforms to begin a system of result-based payments for improved forest carbon management (Zwick, 2014), one of which is OMI. OMI is a nationwide governance program that aims to consolidate spatial data in order to develop one integrated geographical information system for Indonesia (Samadhi, 2012). In the context of forest governance, data discrepancies in the forestry sector have caused confusion over forest spatial information and contributed to land tenure conflicts and overlapping concessions (Galudra et al., 2010). The "green economy" of REDD+ requires a much cleaner and more stable forest landscape to attract carbon investors (Brockhaus et al., 2012). OMI aims to create this security by fixing the way forest spatial information is produced and used to govern forests in Indonesia.

Harvey (1999) argues in his notion of 'the spatial fix' that for capital accumulation to effectively operate it requires various practices of spatial reorganization to ensure the functioning of financial investment. This is the case with REDD+ implementation in Indonesia. It demands fixed forest territories upon which climate finance can be securely invested and expanded. Harvey's re-interpretation of Marx's notion of capitalism and his proposed concept of spatial-fix incited a series of attempts in theorizing the relation between society and space (Harvey, 1999). For Harvey, space is a relational concept, it lies in the social relations of actions. Thus, space is not merely a static technical construction of landscape where things exist (Gregory and Urry, 1985; Soja, 1985). Post-structuralist theorists, such as Rose (1999), similarly argue that space is a matter of "performance" or "a doing", instead of "a terrain to be spanned or constructed" (cited in Gregory et al., 2009, p. 709). 
Following post-structuralist thinkers, such as Michel Foucault, Gilles Deleuze and Felix Guattari, human geographers employ spatiality to indicate "the ways in which mobile constellations of power/knowledge and subject positions are constituted through the production and performance of space as an 'ordering' rather than a fixed and closed order" (Thrift, 2007, p. 55 cited in Gregory et al. 2009). This chapter draws from this notion on spatiality by seeing OMI as a set of practical and discursive orderings constructed from particular configuration of diverse governmental technologies and knowledge that is not fixed, and can be challenged as well as disrupted by other knowledge systems that it tries to exclude.

Forest space as a social product means it can be constructed to serve particular interests and therefore might prolong social inequality. In his book, The Production of Space, Lefebvre (1992) looked to capitalism as a key component of the formation of spatial inequality. So is the case with Indonesia's forestland governance; state actors in league with capitalist entities "select victims at their convenience and write the rules to legitimate their actions" (Li, 2007c, p. 5). This is apparent in what (Peluso and Vandergeest, 2001) called "political forests", a terminology used to explain the measures taken by the Ministry of Forestry (MoF), as state representative, to dispossess land from Indigenous people and claim it as a state's land (see Chapter Four). These measures include technologies of territorialisation, zoning, inscription of law and its enforcement, as well as "criminalizing many previously common practices" (Peluso and Vandergeest, 2001, p. 763 see also Chapter Four).

As the leading site for REDD+ finance the experiences of Indonesia with initiatives like OMI will influence how REDD+ evolves in other countries. The aim of this chapter is to analyse how OMI is transforming forest governance in the Indonesian context. The chapter explores how new forms of governmental technologies are being generated to produce "governable spaces" for forest carbon investment, and the consequences this is having for forest stakeholders. The chapter is particularly interested in how the processes of producing spatial knowledge provide openings and closures for more progressive forms of forest politics. I analyse the new institutions, knowledges and practices that are becoming dominant in forest 
governance and the role and influence of state and non-state actors (Ilcan and Phillips, 2010). In adopting an environmentality approach I outline what aspects of forest governance are being problematized; what technical solutions are being constructed; and who is influencing the production and content of these solutions (Agrawal, 2005; Fletcher, 2010 see also Chapter 2).

My argument is that discourses of the green economy are transforming the way spatial knowledge is produced, distributed and stored. The technologies are being used to problematize certain forest governance issues in non-confrontational ways, while avoiding and obscuring politically sensitive problems. In doing so they seek to generate consensus amongst forest stakeholders in favour of the green economy. However I also argue that the processes through which new forms of spatial knowledge are produced are contested, providing new opportunities for non-state actors to shape the production of forest knowledge. As a consequence governmental technologies are outcomes of negotiations of state and non-state actors, and reflect the particularities of place. Thus I argue that neoliberal governmental technologies, such as REDD+, should be seen as sites of struggle, redefining the rules, actors and forms of engagement for all involved, in complex and contradictory ways.

\subsection{REDD+ and the Problematizing of Indonesia's Forest Governance}

In the following sub-sections I focus on three governmental technologies of forest governance that have emerged as a result of OMI and Indonesia's interests in green economies of REDD+: forest moratorium policy; One Database of forest licensing; and One Standard in participative mapping. In each case, problems of forest governance are defined and technical solutions supplied. However rather than erase forest politics by rendering it technical this chapter explores how non-state actors and particular government agencies have engaged these technologies and pursued strategies to reflect their diverse political interests. Hence by examining this moment of forest reform this chapter exposes the politics of rendering technical, showing how new technologies are not imposed untroubled from above but are 
negotiated through existing political economies of forest governance (N. Rose, 1999b; Li, 2007c).

\subsubsection{The Forest Moratorium as a Technology of Governance}

In this section I examine the establishment of a forest moratorium, which employs elements of Fletcher's disciplinary and sovereign environmentalities (Fletcher, 2010). According to Fletcher (2010) disciplinary environmentalities are pursued through internalising norms and values. Disciplinary approaches aim to produce docile subjects who will act according to shared values and ethics that are considered to be in the best interest of the society (Agrawal, 2005). Sovereign environmentalities are accomplished through the execution of top down regulations which establish rules for how people should behave - through fences and fines for example (Fletcher, 2010).

The moratorium, a key milestone in Norway's \$1 billion commitment to REDD+ in Indonesia, has two key objectives (Sloan, 2014, p. 37):

(i) cease licensing in 'primary' forest areas, at least temporarily, in order to dampen high rates of forest loss; and (ii) during this cessation, integrate registries, maps, and regulations concerning the extent and status of licenses and forest cover, to allow for rational forest management.

The moratorium policy renders current practices of forest governance visible and problematizes them - implicitly positioning current arrangements as irrational. The policy recognises the need to slow forest loss and to improve forest data if green economies based on forest carbon economies are to be realised.

\section{The Politics of the Moratorium Policy}

From February - May 2011, the 'climate society', a mailing list in which environmental activists exchange news related to policy development, opening of grants, and job vacancies, was inundated with discussion on the frustration over the 
postponement of the long awaited moratorium policy 9 . One of the emails sent by WALHI's activists highlighted the number of forest concessions that had been granted while the policy was being discussed. My observation on the email traffic shows that most of the activists accuse the MOF of an intentional postponement to give a window of opportunity for the business sectors to secure permits before its execution (A. Dermawan et al., 2011; Surya, 2011; Luttrell et al., 2012). When finally the President signed the instruction on 20 May 2011 (Saloh and Butler, 2011), a total of 111,419 ha of forests had been approved for 9 companies in Central Kalimantan, just in time to be exempted from the moratorium (Surya, 2011). Moreover, a total of 6,763 ha of Central Kalimantan's forests that fall under letters of principle approval will also be spared from the moratorium (Surya, 2011). This data strengthens the activists' cynical view that the development of moratorium policy was influenced by vested interests in the business sector (Interview, Yunus, July 2013).

In an interview with the Jakarta Post - a national newspaper, the head of the REDD+ Taskforce, Kuntoro Mangkusubroto, expressed similar frustration over the production of the policy by saying, "Our move [on the forest moratorium] has been sharply observed by lobbyists such as mining companies and oil palm plantations" (Simamora, 2010). During an interview with a World Bank consultant who serves the REDD+ Taskforce as a governance expert, he revealed the contestations that took place;

There were three drafts available on President's table. One comes from UKP4 and the REDD+ Taskforce which was the strongest in terms of effort to protect forests, the second draft proposed by the MOF, and the last one which was also the weakest comes from the Coordinating Ministry of Economic Affairs. This latest draft is the one that accommodating toward the business sector's interests. UKP4 and the Taskforce worked hard, they pushed, however, the political deal is a process that's hard to predict, especially when your enemy has more connections and power. You know ... the Minister [for

\footnotetext{
${ }^{9}$ I obtained the information from a personal observation as one of the members of the mailing list.
} 
the Coordinating Ministry of Economic Affairs] is soon to be the President's in law and that the Minister also shares the same political party with the MOF's Minister. We cannot deny such things played role ... and particularly because business sectors have a lot of money to hire lobbyists to make sure they got what they want (Interview, Mursidi, May 2013)

The statement above shows that decision making in the forestry sector in Indonesia occurs behind closed door and thus likely to be influenced by the interests of the few rather than the interests of all (Ross, 1996; Saich et al., 2010; A. Dermawan et al., 2011).

The moratorium was finally announced in May 2011 through the issuance of Presidential Instruction Number 10/2011, which prevents a range of government authorities, including the MOF as well as district heads, from issuing new forest licenses. Covering around 60 million ha of forest areas (peatlands and primary natural forests), the Presidential Instruction on Moratorium exempts four types of activity (Government of Indonesia, 2010b; Murdiyarso et al., 2011; Indrarto et al., 2012). First, the moratorium excludes forest lands that have been subjected to inprinciple approval prior to moratorium (Murdiyarso et al., 2011). This approval is a step in gaining a forest permit that means the application has been approved by the Minister of Forestry. In the forest licensing system, the approval is then be followed by a process of forest boundary delineation and finalized with concession granting. Second, the policy exempts areas that are required for activities considered as vital for national development projects, including for instance, geothermal development, extraction of oil and natural gas, electricity (coal or hydropower), and the opening of forest for rice and sugarcane plantations (Murdiyarso et al., 2011).

Third, the policy also excludes land that is already burdened by existing forest licenses (Murdiyarso et al., 2011). The last exception is for land that is proposed for ecosystem restoration concessions (ERC) (Saloh and Butler, 2011). ERC is a permit to manage production forest for conservation activities that was first introduced through the MOF's regulations No 159/2004 and No 18/2004, and subjected to revisions in 2007 and 2008 (Sitompul et al., 2011). ERC is the only forest concession 
that can be used by the private sector to propose a REDD+ project in Indonesia. By owning ERC, a REDD+ project proponent will be granted the right to sell carbon credits to carbon market (Sitompul et al., 2011). This latest exemption is perhaps the only one that can bring positive impact to the nation's effort to reduce deforestation (A. Dermawan et al., 2011; Murdiyarso et al., 2011). Those that breached the guidelines would be breaking the law. As such the Instruction seeks to govern how government officials and the private sector conduct themselves at various scales of authority, including national, province and district levels of government.

However, the moratorium's focus on peatland protection was widely contested by the business sector, particularly from the Association of Palm Oil Companies that accuses the moratorium of being unconstitutional (Bisnis Indonesia, 2010; Simamora, 2010; Lang, 2013; Lubis, 2013). The association argues that the moratorium is overruling the Ministry of Agriculture's regulation Number 14/2009 that prohibits exploitation only in peatland with more than 3 meters depth (Interview, Januarto, July 2013). Promoting economic rationalities regarding the threat to national economic growth and loss of employment opportunities, the association opposed implementation of the first moratorium (Bisnis Indonesia, 2010; Medan Bisnis Daily.com, 2011; Astuti, 2013). The Secretary General of the association expresses his rage in an interview saying,

I don't know why the government bows to other government's order just because we are promised to be paid 1 billion dollar. Where is our dignity and sovereignty? ... that amount of money is nothing compared to the revenue from palm oil sector that reach 18 billion dollar per year. Palm oil sector is the hero of the nation's economy! But we got attacked domestically and internationally by a lot of NGOs ... Do you know who sponsored these NGOs? The US and other countries that want to sell their vegetable oils and get rid of palm oil from the market. It's all about economic war! Nothing else, let alone environmental protection! They are smart, they use it [environmental protection issue] as their strategy! (Interview, Januarto, July 2013). 


\section{Problematization of Forest Governance through the Moratorium Policy}

To legitimise this substantial shift in forest governance, where the autonomy of government agencies in allocating licences was suspended in favour of shifting to a green economy, REDD+ proponents sought to problematize existing arrangements. The UKP4 and REDD+ Taskforce criticised how forest spatial information was manufactured, distributed, and stored by the MOF and other technical ministries or local government agencies. They drew on data discrepancies in the forestry sector that have caused confusion over forest spatial information and led to land tenure conflicts and concessions overlap. Such discrepancies are common, resulting from the interest of particular actors, both at the district or national level, that profit from retaining the ambiguity of forest spatial information (Fay, Sirait and Kusworo, 2000).

In its latest study on the overview of Indonesia's forest situation, Forest Watch Indonesia - a national environmental NGO - asserts that there were seven million hectares of overlapping forest concessions and a total of 2585 tenure conflicts during the period of 1990 - 2010 (Purba et al., 2014). The REDD+ Taskforce used this sort of information to legitimize the moratorium, cognizant of the need for a cleaner and more stable forest landscape to attract REDD+ investors. Carbon investment is likely to be more successful, and space more governable, if it is implemented in a conflict free landscape where there is clarity over who has the right to the carbon (Brockhaus et al., 2012).

The forest moratorium renders problematic both the practices in which forest lands are being governed and the governing institution (the MOF) which is positioned as lacking the political will and capability to implement the moratorium. A tactic used by UKP4 and REDD+ Taskforce officials was to draw on a map depicting two different versions of primary forests on Papua Island to problematize the asymmetrical coordination and information exchange between different state agencies (Figure 6.1) (Samadhi, 2012). One of the maps came from the MOF, while the other came from the MOE and they were both presented as official maps in the cabinet meeting chaired by former President Yudhoyono to discuss the implementation of moratorium policy. The maps reflect the degree of uncertainty in 
Indonesia's forest spatial data and at the same time underlie the more complex problems in its governance. Due to unclear forest boundaries, different methodologies in mapping and inconsistencies in defining what is considered as primary and secondary forests, there are at least two different official sets of data pertaining to primary forest in Papua Island. Data from MOE shows 59.8 million ha of forest cover, while MOF data records only around 44.2 million ha (Samadhi, 2012).

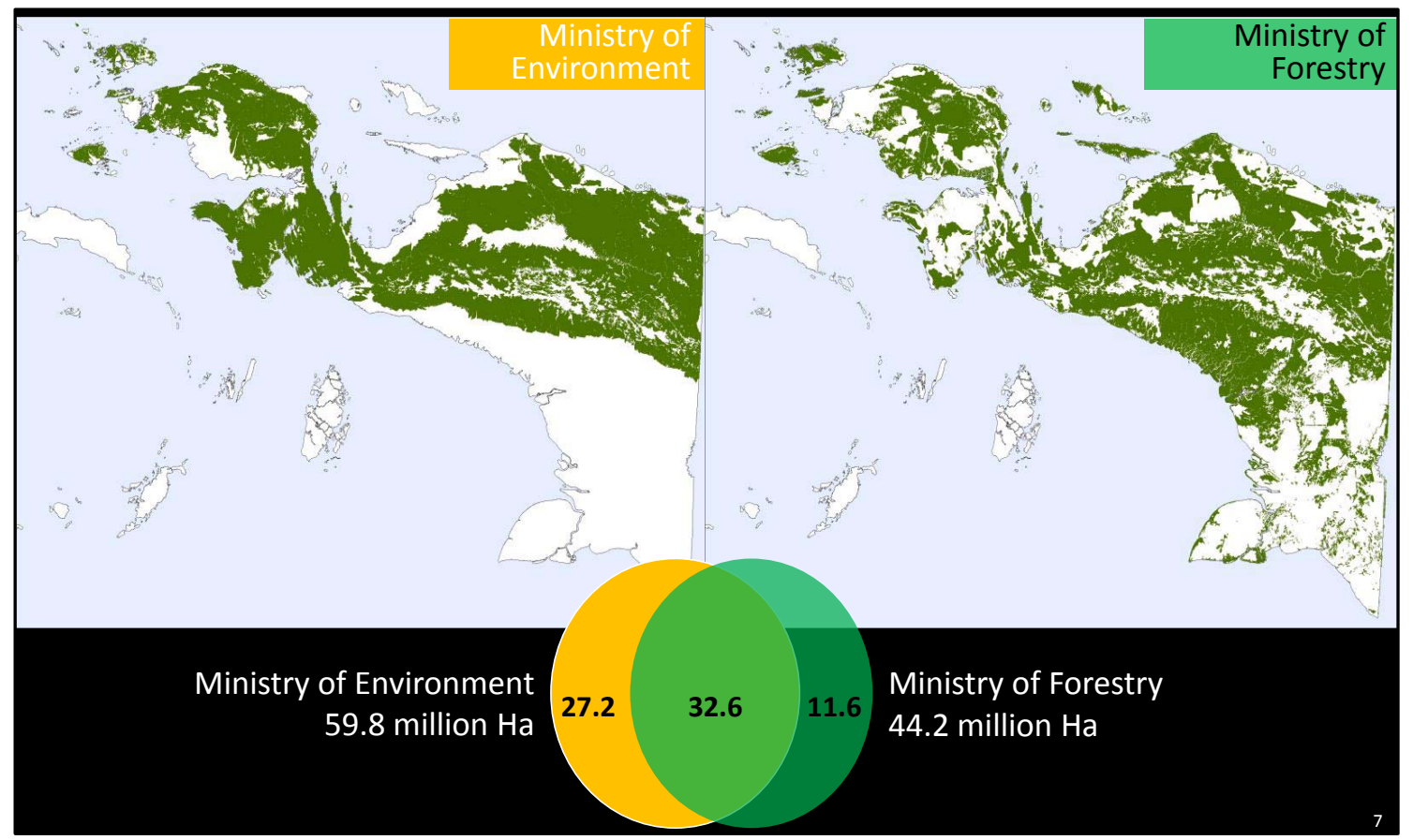

Figure 6.1 Maps of forest cover in Papua Island

(Samadhi, 2012)

Having established the problem, the REDD+ Taskforce and UKP4 position the forest moratorium as a technology of government that can overcome the fragmentation of forest spatial information and knowledge (Government of Indonesia, 2010b). To implement the moratorium required new practices utilising what Scott (1998) defines as a process of simplification. That is an attempt to generate a particular reality of the object of governance by showing only information that will support the authority of the governor instead of more complete and complex representations of 
the issue. The moratorium policy introduces new terminologies, in this case "primary natural forest", in its attempt to technically classify diverse Indonesia's forests into two types: primary natural forest and secondary forest (Murdiyarso et al., 2011; Sloan, 2014). The first article of the Presidential Instruction states the implementation of the moratorium will cover only primary natural forest and peatland. This has caused considerable confusion and contestation over its meaning (Murdiyarso et al., 2011). For instance, the new terminology has been interpreted by some as primarily undisturbed forests, which means the moratorium covers only a proportion of forests that are already protected under the administration of national park and wildlife sanctuaries (Permatasari, 2011).

The moratorium is being implemented and mainstreamed through a range of participative technologies that were introduced by the REDD+ Taskforce and UKP4. This includes a requirement for six key state agencies to collaborate in order to produce and disseminate an Indicative Moratorium Map (IMM) that shows forests and peatlands covered in the moratorium area (UKP4 and Satgas REDD+, 2013). In addition a Working Group on Forest Moratorium was formed with members being composed of government agencies as well as civil society groups monitored by UKP4. These groups and particular government agencies were to report on 30 technical moratorium activities, each with its standards of achievement (UKP4 and Satgas REDD+, 2013). For example the IMM is subjected to six monthly reviews based on public feedback and findings from field research. Its public availability in digitalised format means forest stakeholders can challenge or monitor the effectiveness of the policy. These activities and standards provided UKP4 and REDD+ Taskforce with a means to measure and discipline government agencies and other participating groups.

These strategies had the effect of rendering technical some of the complexities of Indonesia's forest political ecology. It obscured sensitive issues of corruption and rent seeking practices in Indonesia's forest governance. Instead the problems of forest governance in Indonesia are constructed as being technical issues, deriving from a lack of comprehensive spatial data and weak inter-ministerial coordination. Following $\mathrm{Li}$ (2005) I recognize how this practice of rendering technical is 
generating new methods of governance. By appearing apolitical, outright accusations are avoided and government agencies are able to sit at one table to discuss technical solutions. While NGOs risk depoliticisation by participating in policy making, the formation of these new technical policies can also be "politically productive as it has the potential to open up new sites of political contestations" (Barry, 2001, p. 208). NGOs are using OMI as an opportunity to raise questions about social and environmental justice concerns.

Relying on data collected through field verification, for example, the NGO, WALHI Central Kalimantan has highlighted illegal activities of several palm oil plantations that are still clearing forests despite being included in the areas protected by the moratorium (Fandi, Nugroho and Niun, 2013). Such practises use the rules of the moratorium to pursue social justice outcomes. WALHI Central Kalimantan's director expresses his fury over the impotency of the Presidential Instruction in addressing tenure conflicts and environmental destruction by saying,

The hive is in Jakarta, here [Central Kalimantan] is different, the everyday situation that we [WALHI Central Kalimantan] face is to witnessing people get beaten and even go to jail just because they want to protect their land. The moratorium is far from addressing the problems the people face on the ground. Sorry to say this ... but this is just another impotent policy! (Interview, Rajiman, October 2013).

Such critique is powerful because WALHI Central Kalimantan possesses fieldwork data, consisting of GPS points of the plantation companies' locations that overlap with the moratorium area. This kind of data, which utilises the terminologies and technologies of the government, are hard for the MOF to contest.

Despite improved transparency and opportunities for participation in forest governance civil society has actively contested aspects of the moratorium. NGOs were concerned that it only covered forest under the classification of "primary natural forests" and peatland while leaving secondary and disturbed forest 
unprotected $^{10}$ (Murdiyarso et al., 2011). Activists accuse business sector lobby groups for the new terminology which can serve to protect their economic interests. CIFOR ${ }^{11}$ scientists (Murdiyarso et al., 2011) assert that the exclusion of secondary forests in the moratorium means leaving more than 46.7 million ha of forests rich in carbon and biodiversity unprotected. Raising similar concerns, a Greenpeace campaigner explains his view on the moratorium,

This is a bold move from the government in an effort to protect what remains left in our destructed forests ... the only problem is that this is inadequate. It doesn't add much to protect forest areas that currently sit outside the existing national parks or other conservation and protection forests... It undermines the reality that some of the areas that fall under the secondary forest category are home to some of Indonesia's iconic fauna. You know, these areas are more prone to forest clearing from business expansion than the areas under the banner of a national park (Interview, Patrick, July 2013).

An activist from HUMA, an environmental NGO based in Jakarta, further problematizes the moratorium saying, "because the secondary forest is not part of the moratorium area, the policy will overlook the social problem caused by tenure conflict that mostly occurred in already allocated forests [for business activities]" (Interview, Kipeli, March 2014). Indeed the moratorium policy is often simplified as a contestation between ecological and economic rationales while social justice considerations are left aside. This reflects Li's concerns that in presenting technical solutions policy makers often ignore the social, political and economic factors in designing policies and programmes (Li, 2007c).

\footnotetext{
10 The MOF doesn't officially adopt forest classification based on secondary or primary categories. The terminologies of "secondary" and "primary" forests are used only when the MOF submits reports to the Food and Agricultural Organization (FAO) to adhere to the scientific categorization that the FAO applies. Primary natural forest is a new category that was formulated by the MOF to denote forest areas that are never been subjected to forest licensing (for business purposes, such as logging concession).

${ }^{11}$ CIFOR is a non-profit international research institution that conducts research on the intersection between forest, landscapes, and human interactions. CIFOR headquarter is located in Bogor, West Java, Indonesia.
} 
While most of the environmental NGOs accuse the moratorium of intentionally leaving secondary forest unprotected, Greenomics, a national environmental NGO, argues that the moratorium map has deliberately incorporated nine large blocs of secondary forests into the moratorium area (Dabu, 2011; Ekuatorial.com, 2011). It argues that the MOF deliberately classified these secondary forests into primary natural forests to depict Indonesia's still expansive primary forest. According to Greenomics most of the blocs are located in conservation forests in Sumatra and Kalimantan (Dabu, 2011). This statement reflects the broader history of mistrust civil society organisations have toward the MOF.

The new practices and policies described above do not guarantee improvements in forest governance. Instead they reveal some emerging strategies in governing the production of forest knowledge in ways that fit the requirements for forest carbon investment. Through OMI, REDD+ proponents have prescribed technocratic approaches to fix spatial truths about forest land use in the hope to generate governable spaces for REDD+ implementation. The production of these spaces entails the adoption of new rationalities of forest governance. For Indonesia to attract REDD+ investment, UKP4 and the REDD+ Agency/Taskforce have attempted to render technical the process of rearranging entrenched power relations within the forest sector. This has involved strategies that ultimately seek to modify and discipline the conduct of state agencies and concessions holders in apolitical ways. It has also provided openings for NGOs to pursue their own politics through participative openings in the technical processes. However, success has been varied. In the following two sections I take a closer look at two other technologies in the context of OMI: the One Database and One Standard technologies.

\subsubsection{One Database as a Technology of Governance}

One Database targets the conduct of the private sector, forestry officials, and district authorities to make them more accountable for effective green economy investment (Samadhi, 2014). One Database enables the state to represent and classify the messiness of Indonesia's forest licenses data into an organization of centralized, audited and standardized knowledges (Scott, 1998). Li argues that these practices of 
homogenization, standardization and centralization "do simplify, but they also generate something new" (Li, 2005, p. 389). In this case UKP4 and the REDD+ Taskforce officials collect data and facilitate the implementation of One Database pilot projects in three districts. They problematize deficiencies in the governance of forest concessions and propose technical solutions: 1) collection and storage of licenses data in one centralized database, and 2) development of a "situation room" a system of national surveillance that will enable monitoring through a real time satellite data. However, Scott (1998) reminds us that experts tend to produce data that only facilitates the connection between problems and their proposed improvements, while obscuring other relevant information. Thus, improvement projects often risk being compromised by needing to be seen as a solution whilst obscuring the sources of problems, as I will show to be the case in One Database technology.

The REDD+ Taskforce has problematized forestry and district officials for utilizing loopholes in forest governance, caused by the unavailability of consolidated maps and lack of clear forest boundaries, to facilitate corrupt acts. Consequently, multiple concessions are issued for the same area creating hotspots of land contestations and conflicts. As argued at the beginning of the chapter, carbon investment in REDD+ is likely to be more successful if it is implemented in a conflict free landscape. Therefore, addressing the messiness of forest licensing governance became a priority for UKP4 and the REDD+ Taskforce, and pursued through the One Database technology as part of OMI.

Despite the availability of a set of regulations that governs the mechanisms for issuing concessions, the process of getting one is often seen to rely upon securing favourable terms from close political ties or through bribing government officials (A. Dermawan et al., 2011). During an interview with the Director of Rimba Makmur Utama (RMU), a proposed private REDD+ project in Central Kalimantan, he describes the experience of seeking the Minister of Forestry's approval for his project, 
More than four years past by and I have personally collected 350 signatures required for the concession to finally reach the Minister's table. I did not pay even a cent for under the table transaction [bribe]. It was hard, but, I think it worth every step that I have been taken. It's a green business ... I want to do it right and to show that it is possible to get things done without bribery in Indonesia. Everytime someone ask about the progress of the concession, I jokingly say "I think the Minister forgot to bring his pen everytime he intends to sign it" (Interview, Wanmarda, July 2013)

RMU's case has been utilized by REDD+ proponents to highlight and problematize corruption practices in the forestry sector. In contrast Rimba Raya Conservation, another private REDD+ project situated in Central Kalimantan, was widely rumoured to get the Minister's approval because of some powerful figures on its Board. The institutionalisation of closed-door decision-making and corruption amongst forestry agencies is problematic for green investment.

UKP4 and the REDD+ Taskforce have initiated an improved licensing process in three REDD+ pilot provinces: Central Kalimantan, East Kalimantan and Jambi (Samadhi, 2014). Three districts in Central Kalimantan have been piloted for the programme - Barito Selatan, Kapuas and Kotawaringin Timur. UKP4 and REDD+ Taskforce officials describe the effort to transform licensing governance through One Database as a radical measure in opening up forest licenses data, making it available for public scrutiny. The aim is to prevent discreet decision making in granting concessions and "under the table" transactions. As previously mentioned this is to be achieved through development of an online centralised licensing registry and the establishment of "situation room", a national surveillance system that relies on real time satellite data (Samadhi, 2014). The registry collects and digitises concession documents and improves archiving mechanisms.

The centralisation of licences data involves a licensing audit reviewing the legal status of concession holders, legal status of permits, environmental sustainability performance, land tenure, and tax/royalty payment compliance (Samadhi, 2014). The consolidated registries will make visible the allocation of forestland for private 
concessions. Thus, it will provide a platform for forest governance transparency that enables more informed contestation and critiques. In addition to legal documents, companies are requested to send maps and coordinate points of the concession location to the audit team. The spatial data is used to generate a consolidated map of forest concessions and evaluate the overlaps on areas that are subjected to multiple claims. A REDD+ Taskforce official explained that in the near future the consolidated map of forest concessions will be overlaid with a map of tenure claims from Indigenous and local communities to assess hotspots of contestations and seek resolutions (Interview, Josyana, September 2013).

In each district, the pilot activity for One Database addresses two types of licenses; mining and plantation concessions that have been issued both in the state forest area and in forest classified as other land uses. A UKP4 official explained that they chose these two concession types because forest clearance from plantation and mining expansion are the main drivers of deforestation (Interview, Denis, July 2013). Most land tenure conflicts are also found in these two types of concession area. At provincial and national levels, the situation room functions as a control room to store digitalised data of concessions registry and monitor forest changes, such as from deforestation or forest fires. The situation room provides a form of centralised surveillance that enables the monitoring of concessionaires' activities in relation to their concessions areas from afar. Using satellite technology that provides real time images, and also supported by the provision of a consolidated concessions map, forest monitoring is anticipated to become much more effective. It is expected to reduce illegal logging by prohibiting concessionaires from illegally appropriating forest lands by clearing areas beyond the defined boundaries allocated. The digitation of licensing data provides a system for local and central governments to track companies' compliance in accomplishing tax and royalty payments. As a set of practices the One Database technology encourages forest stakeholders to self govern their conduct in ways that fit broader forest sector interests, including those of carbon economies.

However the simple action of collecting concession documents has proved difficult. UKP4 estimates only 5 to $40 \%$ of the data is readily available at the district level 
(UKP4 and Satgas REDD+, 2013). Most of the documents were not available either because of poor documentation or the intentional action of hiding information. In an interview, a district official claimed he is worried that the findings from the audit will put himself and his acquaintances in jail (Interview, Trigunawan, November 2013). According to UKP4 one of the challenges of collecting concessions documents has been the objection from several District heads to share what they classify as 'sensitive' data (Interview, Wandi, September 2013). Sensitive data usually includes illegal concessions that were issued because of bribery or data documentation that shows how officers intentionally overlook noncompliance activities. Discontinuity of data documentation from one administration regime to another is another major obstacle. To ensure the cooperation of the district officials, UKP4 officials attempt to convince district authorities that the findings from the audit process are not going to be utilised for legal actions that could criminalize them as a form of compromise (Interview, Wandi, September 2013). Instead, the rationality of increasing local revenues from plantation and mining tax and royalty is employed to convince the district officials to cooperate in the licenses audit process.

The new practices of governing forest licensing system through One Database rely on the technical processes of consolidating registries and other spatial information. The registry database produces new forms of knowledge and creates particular truths about forests that are governable and will be beneficial for carbon investment. The truths that emerge, however, are compromises negotiated through relationships between state and district officials, tempered by concerns about accessing sensitive information and fears of illegality and prosecution. In promising not to use the data to charge corrupt officials, UKP4 and the REDD+ Taskforce have sought to render technical and depoliticise histories of corruption and injustice. This is seen as the trade-off for the production of more governable forest spaces.

\subsubsection{One Standard as a Technology of Governance}

A further technology introduced through REDD+ has been the "One Standard" principle aimed at governing participative mapping practices, its proponents and their integration in OMI. It does this through standardising how participative maps 
are made, circulated and used. The government's approach is informed by the necessities of the broader neoliberal environmentalities underpinning REDD+, while opposition is structured around and based on respect for the knowledges of forest communities, making claims based on Fletcher's truth environmentalities (Fletcher, 2010). Truth environmentality is exercised based on "particular conception of the nature and the order of the universe", for instance, beliefs in a non-material relationship between humans and nature as is common in some Indigenous societies (Fletcher, 2010). People come to govern themselves in accordance with spiritual beliefs and traditional rules and customs.

As argued earlier, in order to deliver effective governance, the state will try to render technical their object of governance, however, Scott (1998) argues that this practice of simplification is routinely resisted by actors such as NGOs. Li (2005) further extends Scott's explanation by highlighting the possibilities of critical engagement, as "resistance involves not simply rejection but the creation of something new, as people articulate their critiques, find allies, and reposition themselves in relation to the various powers they must confront" (p. 391). This is the case with the network of Indigenous and environmental activists' resistance toward the government's version of participative mapping standard. However, rather than outright refusal, activists have proposed a new standard aimed to promote the integration of Indigenous spatial knowledge in the state geospatial system as discussed below.

Geospatial law Number 4/2011 requires all of maps recognised by the state to follow a particular standard to ensure technical compatibility and validity. By integrating maps produced through participative mechanisms, such as Indigenous maps, the process seeks to clarify contestations over land tenure. This is important for REDD+ in Indonesia, as the successful implementation of the new carbon economy relies on its capacity to emphasize its non-carbon benefits, including Indigenous tenure rights. The development of a standard is an attempt by the state to produce a governmental technology to regulate and discipline the conduct of participative mapping proponents (Dean, 2009). The standard envisions a unilateral cartographic language that will ensure the conformity of participative mapping 
practices into modern cartographic conventions. It requires the proponents to submit to the practices, and thus values, of modern cartography, the very technology that has previously been spatially capitalized by the state to dispossess Indigenous and local communities of their land and resources (Peluso, 1995; Mundy, 1996; Wainwright and Bryan, 2009).

If mapping means asserting claims and controls over particular territory, a standard on mapping is a measure to govern the way claims and controls are to be made. A standard can have both empowering and disempowering effects for marginalised communities. On one hand it becomes the means of translating the community's land tenure system into spatial information, which will technically be accepted and understood by the government (Peluso, 1995). On the other hand, a technical standard strengthens modern science domination of Indonesia's state cartography system and risks marginalizing traditional or Indigenous spatial knowledges.

The Geospatial Information Agency (GIA), the government agency whose mandate is primarily to oversee the governance of spatial information in Indonesia, prepared the first draft of the standard during late 2012. The draft consists of four technical documents. The first document explains the procedure of geospatial data provision for participative mapping proponents. The second document regulates the mechanism for participative mapping proponents in updating and adding names of places in GIA's geospatial system. The third document governs the quality control process for maps produced through participative mapping mechanisms. The last document standardizes a mechanism for acquisition and integration of these maps in OMI system. GIA held a series of public consultation meetings, through which NGOs, represented actively among others by Jaringan Kerja Pemetaan Partisipatif (Participative Mapping Network, hereafter JKPP), were invited to give feedback. In an interview, a JKPP activist argues that despite its technical complexity, the development of the standard is a sign of the government's political will to create a platform that will engage communities in the production of spatial knowledge and policy; 
The standard is complicated, it uses a lot of technical language ... I don't think the communities or even NGOs that facilitate the participative mapping process will easily understand the meaning of all the technical terminologies. We have to create a standard that reflects the needs and level of technical knowledge that the communities and NGOs own, while seeking to meet the technical requirements of mapping in Indonesia. For the communities, the maps they produce are their weapons to defend their land ... we cannot create a system that will limit the effectiveness of the communities' weapons (Interview, Nagara, June 2013).

In addition to the proposed standard, GIA and the REDD+ Agency launched an online application system for participative mapping in late August 2014 (Saturi, 2014). The online application theoretically enables every citizen or community group in Indonesia to add spatial information to the basic map. This information can be added directly by the local community through the participative mapping application system and will be followed with data verification by GIA to determine its validity and technical compatibility according to national cartography conventions (Saturi, 2014).

JKPP have also problematized the paradigm of participative mapping developed in GIA's online application. They have challenged some of the core assumptions within GIA's approach and have been developing an alternative standard for forest authorities to adopt. In GIA's standard the meaning of 'participation' is reduced to the involvement of community or other non-state actors in naming places, rivers, lakes, or drawing village boundaries through the online system. As such, one can argue that GIA's participatory technology has set limited terms for stakeholder engagement. Thus, the technology renders the political complexities of Indigenous communities' land tenure claims into bland practices of inputting and digitizing spatial information. This perspective differs from some NGOs understandings of 'participation' as a mechanism that carefully involves community members in a set of political processes from the initial planning phase, making of the map, up to the decision taking as well as control over the use of the map (JKPP, 2014). 
In contrast JKPP proposes a standard in which counter mapping characteristics are employed as the fundamental paradigm (JKPP, 2014). JKPP's standard emphasises the nature of participative mapping as a social movement, through which dispossessed communities can employ mapping as a technology of resistance (Peluso, 1995). Cobarrubias and Pickles (2009, p. 42) define counter mapping as a new cartography that "is used by social movements ... to refigure the relations of power that structure socio-spatial life and to remap the social spaces of everyday life in ways that produce new political subjects". This definition represents the nature of the participative mapping movement in Indonesia proposed by JKPP, which employs dialogue and inclusive participation in its production of spatial information. Participative mapping embodies the relation between Indigenous or local communities' tenure with the land and resources they live in (Roth, 2009). As such, the constructed map becomes the technology of resistance in assembling tenure claims (Hess, 1995; Peluso, 1995). JKPP's standard advocates the integration of Indigenous/traditional knowledge in the state's geospatial system by insisting on the existence of traditional knowledge that has predated the system developed by the state. This of course has political and practical implications - potentially making Indonesia's forest governance more open to social and environmental justice concerns.

In October 2014 JKPP finalised its draft of a participative mapping standard. The standard starts by describing the rationales that underpin participative mapping. The rationales emphasise the significant role that Indigenous and local communities have in terms of mapping and spatial knowledge, and that need for this to be acknowledged and represented in the nation's spatial governance system. It also emphasizes that the community's possession of spatial knowledge is dynamic and exemplifies the community's tenure rights to their land and resources.

The JKPP standard employs several basic concepts originating from counter mapping principles (Peluso, 1995). For instance, it highlights the role of Indigenous/traditional spatial knowledge as an essential tool for the protection of and struggle for Indigenous tenure rights. The standard addresses the fact that modernism and development - including modern scientific cartography - is a 
dominant knowledge system that tends to ignore and undermine Indigenous/traditional spatial knowledge (Harley, 1989). The standard, therefore, proposes that the state's geospatial system facilitates communities to produce their own spatial knowledge; they are referred to in the standard as the 'knowing subject' (JKPP, 2014). In doing so truth environmentalities are claimed whereby Indigenous knowledges are valorised and positioned as having a role in governance based on intimate connections with place (Fletcher, 2010). Incorporating such approaches only work when there is a mutual acknowledgement of the worth of modern scientific cartography systems and that of traditional spatial knowledge (Aicher, 2014); a basic premise advocated by the JKPP standard.

The JKPP standard relies on two philosophical definitions of participative mapping. First, participative mapping is defined as a process of building a collective understanding aimed at the improvement and sustenance of a community's living space. Secondly, it is also defined as a process of building mutual agreement within the community on the role of participative mapping as a tool to reinforce and strengthen the community's living space. These two broad definitions of participative mapping emphasise how participative mapping can function as a technology of resistance that allow less powerful groups to employ maps as legitimate proof to claim land and resources (Peluso, 1995; Cobarrubias and Pickles, 2009; Wainwright and Bryan, 2009).

The definitions emphasise social principles as well as technical ones. The social principles require the participative mapping to be initiated from the community's collective agreement, in which the agreement has to be arranged through the Free Prior Informed Consent protocol. Social data must also be produced to represent the culture, language, Indigenous institutions, tenure system, and other social norms. The technical principles specifically regulate the use of a basic map (Peta Rupa Bumi Indonesia or RBI) provided by BIG as the reference map. It therefore guarantees the technical compatibility between the participative maps produced and the basic map. The principles allow for any kind of technical utilities to be employed in the mapping processes, but require the utilities to be listed in the report. This particular principle is a step forward compared to the draft proposed by BIG which requires the use of 
particular utilities, which according to JKPP activists are difficult to be fulfilled by the communities and their facilitators (Interview, Nagara, June 2013). Thus it confines and limits the community's and facilitator's capacity in conforming to the standard.

However, despite these innovations REDD+ investment requires certainty in the form of fixed borders on a map. While this is a necessary step to delineate the community's land from the state or private sector territory, boundaries in an Indigenous spatial system are not exclusively meant as fixed lines that demarcate between two separate compounds (Roth, 2009). In some Indigenous spatial systems, the boundaries are neither static or fixed but fluid and negotiated (Pramono, 2013). It is a space "produced through practices related to dwelling, to procuring a livelihood, and through interaction with the environment and they are continually shaped through social relations at multiple scales" (Roth, 2009, p. 211). The requirement for the production of fixed boundaries as the condition for legal acknowledgement of particular Indigenous community, stipulated not only in JKPP's standard, but also in most other state's regulations, has triggered the fabrication of imaginary boundaries and creating tensions among communities (see Chapter 7).

The rest of the standard administers the mapping implementation mechanism and the integration of participatory maps into the One Map (see Appendix 1). The mapping mechanism is illustrated in a flow chart, which explains thirteen steps of participative mapping. The flow chart clarifies the role of each of the participative mapping actors, the input and output documents for each steps, and the estimation of required times for each activity (see Appendix 2). The mechanism emphasises participatory principles and dialogues at each step of the mapping, treating the community members as the lead actors instead of merely sources of information. While the JKPP standard is arguably ready to be adopted as a protocol to manage participative mapping in Indonesia, it has to be certified by a national certification body. Commonly it takes almost two years for a document to be piloted and certified, which will then have legal status as a national protocol. One of the participative mapping activists expressed his concern about losing momentum. Whereas now Indigenous rights have become the central attention of government 
institutions, it can't be guaranteed that in two years time the Indigenous groups and their counterparts are going to receive the same level of attention from the government and donor agencies (Interview, Taksaka, December 2014).

The integration of participative mapping into OMI requires not only a standard but also a data custodian as required by the Geospatial Law. The custodian has to be a government agency. The problem, however, is that no ministry is willing to be the custodian for participative mapping, citing technical incapability as the main reason. The REDD+ Agency has offered itself to the proponents as the interim custodian. As the Operational Deputy of the REDD+ Agency said in an interview: "if no government agency is willing to take the role as the participative mapping custodian, then the REDD+ Agency will take the lead to do it" (Interview, Kuswanto, October 2014) . Some activists see this statement as an open challenge from the Agency to other technical ministries especially those whose mandates are related with Indigenous peoples' welfare such as the MOF, the Ministry of Home Affairs, and the NLA. While the REDD+ Agency's willingness to be the interim data custodian will accelerate the integration of participative maps into OMI system, the participative mapping proponents realize the Agency's fragile position in the new government structure under the newly elected President (see Chapter 5). Hence, when the Agency's duties and functions were finally dissolved into the MOEF in January 2015, the integration of participative mapping into the state's geospatial system is under threat.

Nevertheless, JKPP's standard challenges GIA's approach to Indigenous mapping as being a technical exercise and provides an alternative process in which political issues become recognised and embedded in a technical process. It respects and reflects capabilities and categories of local and Indigenous communities' spatial knowledge and brings counter mapping and the idioms of tenure rights, power relations, and knowledge systems into the governance of Indonesia's land. Through engaging with openings provided by REDD+ and struggling for recognition, JKPP has attempted to subvert neoliberal rationalities and modern mapping practices to counter and contest the status quo of forest governance (Anthias and Radcliffe, 2015). Whether or not JKPP's standard will be effective for countering dispossession of land and for defending Indigenous tenure rights will depend to a great extent 
upon how forest stakeholders continue to engage with REDD+ opportunities as a means to mainstream Indigenous/traditional spatial knowledge systems. This necessitates a spatial governance system with a capacity to integrate various forms of socio-ecological knowledge systems as well as cultural diversity (Aicher, 2014).

\subsection{Conclusion}

The biggest challenge for the REDD+ in Indonesia is to transform the messiness of forest governance and produce a "governable space" for international carbon investment. Through the execution of OMI, REDD+ proponents have sought to bring clarity to confusion over forestland use and allocation. Drawing on three technologies of government - the forest moratorium policy, One Database and One Standard - this chapter has argued that the REDD+ Taskforce/Agency and UKP4 have developed strategies aimed at governing the production, distribution and storage of spatial knowledge. In the process they have sought technical solutions to entrenched political problems around corruption, power, land rights, poverty and profit. REDD+ has provided a rationale for restructuring forest governance through the institutionalisation of new forms of knowledge and practice while maintaining an appearance of being apolitical and in the interests of all.

Forest stakeholders have responded differently to the technologies applied. In the case of the moratorium many NGOs saw it as an opportunity to advance their interests and participate in the moratorium Working Group that was set up. Through participation they were able to contest the limits of the moratorium and expose breaches where companies were clearing protected forest, opening the possibility of prosecution. Local authorities responded much more reluctantly to the One Database initiative, negotiating an amnesty with central government for past breaches of forest laws. In centralising licensing processes and setting up a "situation room" REDD+ proponents are seeking to monitor and discipline their conduct. Finally the One Standard initiative of OMI has been contested by some NGOs who have challenged the basic tenets of the standard and advanced an alternative that promotes Indigenous knowledges. One Standard has provided a 
channel for more radical interpretations of participative and Indigenous mapping to find an audience amongst the more conventional cartographers driving OMI.

This research has shown that REDD+ is being pursued through more than just neoliberal environmentalities. Instead elements of disciplinary, sovereign and truth environmentalities are also present in the governmental strategies being adopted by state and non-state actors. This chapter has identified a fertile politics underpinning the production of apparently non-political technical processes. Forest stakeholders are not responding to green economy initiatives in straightforward ways, instead they are exercising agency, strategically engaging in different initiatives to advance their interests. As such initiatives like REDD+ should be seen as sites of contestation where global priorities encounter diverse political ecologies that shape how programs unfold. This is shaking up forest governance, rearranging the roles and subjectivities of different actors. Some NGOs have found themselves working alongside state agencies, having access to what was initially inaccessible spatial data and using this to problematize the quality of law enforcement and programme implementation in the forestry sector. District officials have found themselves under increased scrutiny and surveillance from the state while previously oppressed Indigenous groups are finding more receptive audiences for their customary land rights claims.

As such REDD+ presents new opportunities and risks and reflects a not-quite neoliberal nature project. NGOs have sought to realise, with some success, the overlap between the interests of carbon investors in governable space with their interests in expanding social and environmental protections. Their new alliances with REDD+ proponents place them in more influential positions than previously. However risks emerge through the tacit approval these alliances provide for processes that seek to render forest governance a technical issue. In problematizing the quality of knowledge, rather than the holders of that knowledge, the REDD+ avoids histories of corruption and outright conflict with the stakeholders involved. Past injustices are left unaddressed and existing injustices may be prolonged. There is also a risk that in working with the rationales of the carbon economy, where social justice issues are often considered 'co-benefits' rather than core priorities, that they 
reinforce a paradigm and set of technologies that may ultimately work against these interests (Corbera, 2012). Afterall there are other ways of producing governable space based on exclusions rather than inclusions; rules being designed at the national scale don't necessarily translate well across scales (McGregor, Eilenberg and Coutinho, 2015; McGregor et al., 2015).

However this chapter has described how the visibility of social and environmental justice discourses are improving as REDD+ proponents in Indonesia engage with civil society, Indigenous groups and carbon market rationales during the readiness processes. This trend cannot be guaranteed into the future, and must be monitored as full scale REDD+ implementation based on reducing carbon emissions moves forward in 2016. Despite progress in mainstreaming values of transparency, participation, and Indigenous recognition there are still many challenges ahead to comprehensively shift forest governance from state processes of land appropriation into mechanisms of land redistribution and reterritorialization. On paper Indonesia's OMI appears sound: new disciplinary and participatory technologies are emerging to shift the flaws in current forest governance. However, when examined on the ground, many of the technical approaches prescribed by the REDD+ proponents rarely suit the political economic reality of forest governance. Without taking into considerations the diverse political interests shaping forest governance regimes and addressing the conditions these regimes obscure, OMI may yet do little to improve forest governance. 


\section{Case Study Three Assembling Indigenous Land Claims within the New Political Conjuncture of Forest Governance in Indonesia}

\subsection{Introduction}

In Chapters 5 and 6 I have focussed on REDD+ mainstreaming activities through the REDD+ Taskforce and the production of new governmental technologies through OMI. In this chapter I focus on the third case study of the research to answer research objective 1(c). I analyse how REDD+ related processes and OMI, together with a Constitutional Court decision to acknowledge hutan adat (customary forest) have created a new political conjuncture in forest governance. Together these forces are reshaping Indonesia's forest politics and transform the old forest political ecology explained in Chapter 4 into a new conjuncture. By combining concepts of governmentality (Foucault, 1991a) with notions on practice of assembling (Li, 2007b) and Indigenous territorialization (Peluso, 1995) I trace how AMAN and the Bahanei are using this moment to assemble a set of governmental technologies to propose a land claim in Gunung Mas District, Central Kalimantan. As such the chapter focuses on how REDD+ govermentalities are unfolding at a more local scale than previous chapters.

As has been discussed in Chapter 3, the data for this chapter was collected using a "scholar activism" approach; that is, an approach that sees "research as a process of working together with those whom we are researching" (Whatmore, 2003, p. 90). I delved to a series of advocacy activities that the Bahanei and AMAN Central Kalimantan ${ }^{12}$ (AMAN CK) organised as part of the land-claims-making processes. Apart from being able to observe the conversations, negotiations and contestations

\footnotetext{
12 AMAN Central Kalimantan is AMAN's regional branch that is based in Palangkaraya, the capital of Central Kalimantan Province. The branch is mandated to oversee AMAN's members in Central Kalimantan.
} 
that took part, I also saw this as an opportunity for practical critique (McGregor et al., 2014b) and became part of the assemblage I studied. This embedded interaction produced empirical data that has helped in comprehending the assemblages and practices of Indigenous land claims-making and their relation to the in-situ political conjuncture. I focused my analysis on the governmental technologies the Bahanei and its supporters devised in their attempt to secure land tenure and seize opportunities within the new forest carbon politics.

The remainder of this chapter is divided into four sections. In the first section I analyse the new political conjuncture (what I refer to as forest carbon politics) that is evolving in Indonesia. In the second section I show how disjointed practices and diverse elements are drawn together to assemble Indigenous claims-making in the context of Bahanei. I also illustrate the implication this assemblage has for Bahanei's desires, practices and identities. The third section highlights the tensions and fractures produced within the assemblage and how these trouble simple divisions between land grabs and land claims. The chapter concludes by discussing the progress and obstacles towards more just forms of forest governance emerging in this new phase of forest politics in Indonesia.

\subsection{The New Forest Political Conjuncture and its Implications to Indigenous Land Claims}

"Map your ancestral territory before it is mapped by others...!"

This statement was made by AMAN as a call for its community members to start claiming their land and other natural resources in response to the new forest political conjuncture. Funded with REDD+ readiness grants, millions of hectares of forests are being mapped by communities with the help of NGOs such as AMAN and JKPP to make land claims (Astuti and McGregor, 2015). These are not insignificant, AMAN is intending to claim 40 - 70 million ha forests by 2020 on behalf of Indigenous communities (Saturi, 2013; AMAN, 2014). Indicative of the changing politics of forests, such actions are not seen as counter-claims against the interests 
of the state (Peluso, 1995), instead they attract support and financing from important authorities. REDD+ Agency chairman, Heru Prasetyo, for example, supports AMAN's claim, saying that "Indigenous groups were estimated to hold the rights to around 45 million hectares of forest currently being misused as commercial concessions" (The Jakarta Post, 2014). AMAN's Secretary General believes the claims "will change the face of the nation's land ownership", as it targets more than half of the state forests (Interview, Bonar, October 2013).

Dewsbury (2011) calls for assemblage scholars to delve deeper into the "intensive environment" through which a particular assemblage emerged. In this section I do this by outlining the new political conjuncture in forest governance that is providing the context through which new land-claim assemblages are forming. The new political conjuncture represents an opportunity to move beyond the common portrayal of Indonesia's forests as messy landscapes characterized by chronic tenure problems and systemic corruption (Ross, 1996; Robertson-Snape, 1999; Resosudarmo, 2005; Saich et al., 2010). It also contests the authority of the MOF who currently governs the $70 \%$ of Indonesian territory currently considered "forest estate" (see Chapter 4).

Chapter 4 has discussed the context of forest politics and governance in Indonesia, however, in this section I will recall several information that are essential to frame this chapter's discussion. The concept of "forest estate" (kawasan hutan) was adopted in the BFL in 1967 (Barr et al., 2006). It is a concept that was created by the New Order regime to provide legitimacy for the state to control and claim land from communities, by 'legally' claiming the majority of the forest estate as state-ownedforests (Barr et al., 2006). The state's monopoly of forested land was inherited from the colonial system, which adopted territorialisation technologies such as forest zoning and law enforcement to produce what (Peluso and Vandergeest, 2001) call "political forests". In total, 143 million hectares of the nation's land was declared as forest estate (Barr et al., 2006), providing the MOF with legal authority to govern the forest, while the rest of the state land (outside the forest estate) is managed under the NLA. 
The BFL divides forest ownership into two categories: State and Proprietary forest. The Proprietary forest is defined in Article 1.5 as "forest situated on a piece of land covered by proprietary rights". Meanwhile State forest is defined in Article 1.4 as "forest located on lands bearing no ownership rights" (Wright, 2011, p. 126). Customary forests have been classified within the latter category that made the state their legal owner. Justified by discourses of economic growth and national development, the MOF allocates lucrative forest concessions to the private sector, neglecting de facto conditions on the ground where particular forest areas have long been managed and used by forest dependent communities, including Indigenous groups and ethnic minorities (Fay, Sirait and Kusworo, 2000; Resosudarmo, 2005; Tsing, 2005).

A report published by Greenpeace International (2010) highlights Indonesia's potential carbon loss of 38 Gigatons Carbon (GtC) in the next 30 years due to various ministries' economic development plans to open an additional 63 million ha of forests for expansion of extractive industries including for palm oil, mining, timber, and biofuel. The most interesting part of the report is the explanation that these plans are based on the MOF's analysis of forest areas that are still 'empty' of economic activities (Greenpeace, 2010). The definition of 'empty' rarely represents the real situation on the ground where millions of Indigenous peoples and migrants rely upon Indonesia's forest for their livelihoods. This clash of interests, in the more open post-New Order political environment, has contributed to the propagation of tenure conflicts. A government official revealed in an interview that in Central Kalimantan, the pilot province for REDD+ implementation, 800 of the 1400 villages in the province are heavily infested with either vertical conflicts between communities and companies or horizontal conflicts between locals and migrants (Interview, Bapa Samadikun, November 2013).

Following the fall of Soeharto in the wake of widespread protests in 1998, farmers and Indigenous communities reclaimed and reoccupied lands taken over by the state and private companies associated with the New Order regime (McCarthy, 2000; L. Bakker, 2009). Environmental and Indigenous rights activists assembled practices of opposition that included Indigenous mapping, campaigning, and physical opposition 
through land enclosure and protest (Pramono, 2013). Trainings have been held to enable communities to use simple tools - such as compasses and Global Positioning Systems (GPS) - and to draw maps and record their landscape histories and boundaries as a means of contesting state authority (Peluso, 1995). This marks a substantial shift from the New Order period when being Indigenous was widely perceived and constructed as traditional, wild, backward and poor, resulting in few communities declaring themselves as Indigenous (Li, 2000). In addition, claiming indigeneity was politically risky, as the New Order regime was implementing the SARA (Suku, Agama, dan Ras or Ethnicity, Religion, and Race) policy (Li, 2001). Under this policy, any struggle for Indigenous tenure rights in Indonesia's outer islands risked being labeled a separatist movement, while in Java and Sumatra they were associated with persecuted communist groups (L. Bakker, 2009). Conversely, post 1998, more communities are politically choosing to articulate their indigeneity as part of the strategy for (re)claiming rights over land and other natural resources (L. Bakker, 2009). Assembling Indigenous land claims has subsequently become a core component of many NGO, donor, and community agendas. In the next subsections I outline three components of the new political conjuncture and their implications to Indigenous land claims.

\subsubsection{The Constitutional Court Decision No 35/2013}

The possibilities of a new political conjuncture are most evident in Constitutional Court Decision Number 35 or what is known as MK 35 (Keputusan Mahkamah Konstitusi No 35). The Constitutional Court of Indonesia decided to partially accept the judicial review brought forward by AMAN and representatives of two Indigenous communities, the Kasepuhan Cisitu and the Kekhalifahan Kuntu in May 2013. The judicial review has resulted in hutan adat (customary forests) no longer being categorised as hutan negara (State forests). Instead they have become hutan hak (Proprietary forests) the second of two categories of forest listed in Article 6 of the 1999 Forestry Law (BFL) (Roewisastuti, 2013). The court ruling opens up new political opportunities for Indigenous peoples and their supporters for securing territory and resources threatened by state and private interests. 
One of the activists I interviewed defines the Constitutional Court ruling, as a "postcolonial decision", as he saw it as an attempt to fight against "categorical inequality" that discriminated against Indigenous peoples who were not recognized as rightbearing-subjects in Indonesia's land tenure system. He adds, "I was shaken ... the MOF as the biggest land-holder state institution was finally declared as unconstitutional after more than 20 years governing 70\% of Indonesia's land" (Interview, Ojiyanto, June 2013). By introducing a new term for Indigenous peoples as penyandang hak (right-bearing-subjects) the court ruling is commonly perceived by Indonesian Indigenous movements as a new opportunity to improve the status of Indigenous communities as legal custodians of their customary lands (Rachman, 2013).

Along with the government target to allocate 12.7 million hectares of forestland for community forestry as a result of the court decision, 12 state ministries/agencies are engaged in an initiative to accelerate the gazettement of forest boundaries (Safitri, 2014 see also Chapter 4). The initiative is intended to revisit the "political forests" the colonial government of Indonesia employed to appropriate land from Indigenous and local communities (Peluso and Vandergeest, 2001). Under this initiative a new policy was issued in October 2014 to provide a tool for the acknowledgement of Indigenous, individual and collective land tenure rights within the forest estate (Safitri, 2014). The policy, known as Perber (Peraturan bersama or Joint regulation) guides the procedures for settlement of land claim inside the forest estate. According to one of the team members who assisted the government to draft the regulation, Perber translates the "spirit of land reform by recognizing Indigenous, individual or collective land rights, among others, in the forest lands that have been used for 20 consecutive years or more" (Interview, Marina, October 2014). Following the recognition and validation of land claim, the MOF will allow the NLA to enter its juridical territory and issue a land certificate for the claimant as proof of ownership (see Chapter Four, Safitri, 2014). While the policy is still in its infancy, and contested by some groups, it is expected to provide greater opportunities for recognising Indigenous land claims in Indonesia (Safitri, 2015). 
Despite slow progress in its implementation, the court's decision has been widely discussed among forest stakeholders. A mix of responses has come from the private sector with the majority of them expressing fear over the court ruling that has ignited extensive Indigenous mapping and land claims. In contrast the Indonesian Chamber of Commerce, as the umbrella organization of the business sectors, officially supports the government's initiative to address confusion over land use conflicts (Dewan, 2014). The support is motivated by the need to acquire legal certainty over land status for business security and investment. Drawing on the same reasons, the court's decision is widely praised by REDD+ proponents. In collaboration with AMAN, the United Nations Office for REDD+ Coordination in Indonesia (UNORCID) organized a national seminar discussing the implication of the court's decision for Indigenous peoples' tenure security and REDD+ implementation. In an interview, an officer from the REDD+ Agency highlights the role of tenure security in increasing the chance for having a successful REDD+ programme, saying, "better forest protection is easier to be achieved in a regime of forest governance that respects Indigenous communities' rights over land tenure" (Interview, Josyana, September 2013).

\subsubsection{REDD+ Readiness and Indigenous Peoples' Rights}

The Constitutional Court decision came at a convenient time for REDD+ development in Indonesia. As part of its design REDD+ proponents, under the theme of "Beyond Carbon, More than Forest" (see Chapter 5) promotes tenure security for Indigenous peoples. The REDD+ National Strategy, for example, promotes land tenure reform through Indigenous land survey and mapping; supporting an out-of-court tenure dispute resolution mechanism; and strengthening the implementation of FPIC (Indonesian REDD+ Task Force, 2012). A set of social and environmental safeguards (PRISAI) and FPIC guidelines have been produced and tested in several Indigenous communities including in Central Kalimantan and Central Sulawesi (for a critique see Howell, 2015). Indigenous mapping is included among ten imperative actions that the newly established REDD+ agency has to implement in its 2014 - 2016 programme. Moreover, the agency claims to have been successfully securing representation from Indigenous experts in its multi- 
stakeholder committee (Komite Pemangku Kepentingan) in order to increase participation of Indigenous peoples in REDD+ decision-making. A national program for Indigenous rights recognition and protection through REDD+ implementation was launched in September 2014, where an idea about a special Indigenous trust fund is being explored. The national programme was launched by former Vice President Boediono and endorsed by nine related ministries and the REDD+ Agency (Agustine, 2014). Further action plans and activities are being developed by the AMAN national office for funding by the REDD+ Agency. This indigenization of forest politics is a result of what an academic I interviewed termed a "honeymoon phase" between AMAN and REDD+ institutions (Interview, Yandiman, August 2013).

A particular vision of Indigenous people is shared between REDD+ Agency and AMAN. The vision imagines Indigenous people as homogenous communities that are deeply rooted with their origins and committed to protecting the forests they live in. AMAN's activist statement explains that they are "communities that have been living there [in the forest], nurturing the forest even before Indonesia existed" (MacDonald, 2014). The former head of the REDD+ Taskforce envisions Indigenous people as "communities that will not survive living in a forest that is replaced with palm oil plantations and no longer have mouse-deer (Tragulus javanicus)" (Witoelar, 2013). The Head of the REDD+ Taskforce's Working Group on Multi-stakeholder Engagement states that, "Indigenous people owned the wisdom of treating the forest with care, the wisdom that respects nature and the cultural spiritual values" (Satgas REDD+, 2013b). Such statements perpetuate a romantic image of Indigenous peoples that have little interest in extractive industries and modernity, instead being associated with traditional forms of hunting and gathering. Indigenous knowledge and wisdom is revered for living harmoniously with the nature. Such framings are contributing to a particular romantic environmental imaginary, which I refer to here as the 'imaginary REDD+ Indigenous community'. I use "imaginary” to emphasise its difference from the reality on the ground, where communities are often more heterogeneous in terms of origin and possess multiple interests, including aims to benefit from extractive industries (Li, 2014b). 
Despite several studies that highlight improvements in forest governance since the inception of REDD+ (Agung et al., 2014), the program has attracted plenty of criticisms (McGregor, 2015). An environmental activist interviewed during the fieldwork emphasises how NGOs, especially those which focus on Indigenous issues, are becoming more tolerant toward the 'faulty' design of REDD+'s market based mechanism, saying, "REDD+ is like a ship that everyone now takes a lift on to go somewhere they think is better, but it actually sails in the sea of a capitalistic mode of development; what is good is only temporary" (Interview, Ginting, June 2013). However some studies are illuminating the downsides of this form of development for Indigenous people in Kalimantan. Howson and Kindon (2015) highlight the escalation of local conflicts among Indigenous Dayak villagers in REDD+ demonstration activities areas. Pearse (2013) underlines the inability of a particular REDD+ project to address fundamental social problems faced by Indigenous Dayak communities, such as land tenure conflict, despite the amount of project money being disbursed to pay for consultants' fees. Hence, even within the "honeymoon period", different Indigenous communities are being affected by REDD+ projects in different ways.

\subsubsection{The One Map and Indigenous Mapping}

The final component of the new political conjuncture is the OMI initiative discussed in the previous chapter. In its implementation, the government expects that OMI will identify private rights, including adat (Indigenous) claims, to acquire integrated information on land use and ownership in Indonesia. In this context, OMI has provided important opportunities for Indigenous maps to be officially acknowledged and integrated into the government's spatial policies. OMI is providing communities with a sense of security by defining new spatial arrangements and protections within the state apparatus.

From a governmentality perspective the rush of Indigenous groups to make land claims can be considered as a successful application of OMI as a governmental technology reshaping human-forest interactions. Indigenous communities and their supporters have engaged in behaviours that are seen as in their own self interest 
and that of broader Indonesian, and even international, climate interests. Establishing land tenure and ending histories of conflict and uncertainty produces "governable spaces" for REDD+ projects (see Chapter 6). It is in the interests of the REDD+ agency, donors and REDD+ investors to secure Indigenous tenure rights, which provides a level of security for REDD+ investment in a particular community (Agung et al., 2014). However, securing land tenure in this new political conjuncture has many more meanings than just that, and is leading to new territorialities, new subjectivities, and new forms of inclusion and exclusion across Indonesia. I explore this further by focusing on the village of Bahanei in Gunung Mas District, Central Kalimantan Province.

\subsection{Assembling Indigenous Land Claims}

This section looks into what elements are being assembled to constitute and make Indigenous land claims in the context of this new political conjuncture. I adopt an assemblage approach that focuses on the activities, labour and materials involved in making claims, drawing on the village of Bahanei, in Central Kalimantan, as my case study area. Following Li (2007b) this chapter focuses on the practice of assembling, that is "the hard work required to draw heterogeneous elements together, forge connection between them and sustain these connections in the face of tension" (p. 264), rather than approaching assemblage as a final and complete product of actions. Furthermore, this chapter adopts a governmentality framework to analyse how this assemblage is reshaping Indigenous peoples' desires, practices and subjectivities in this case study area (Foucault, 1991a; Dean, 2009).

Bahanei is located in the upstream part of the River Kahayan's tributaries, in the Gunung Mas District, Central Kalimantan Province (Figure 7.1). Spanning over 8,888 hectares of forested and non-forested land, two thirds of Bahanei's land is included in the State owned Forest Estate. Bahanei is inhabited by 352 households comprised of at least four different ethnic groups: Dayak Ngaju, Dayak Manyan, Java and Banjar. The Dayak Ngaju ethnic group dominates $85 \%$ of the population, followed by $10 \%$ Banjar, and the remaining 5\% coming from ethnic Java and Dayak Manyan. The Dayak Ngaju ethnic group is considered as the founder of the Bahanei, thus, they 
enjoy the privilege of perceiving others as pendatang (migrants) especially the Java and Banjar. The majority of the Bahanei depend on rubber tapping as their main livelihood in which the Ngaju owns $100 \%$ of the rubber plantations. The migrants usually work for owners of big rubber plantations whose access to land can reach up to 20 to 50 hectares per household. This means that the Ngaju controls access to land in the Bahanei while migrants gain access only through marriage with the Ngaju and land sales.

Facilitated by AMAN CK and partially funded by the REDD+ Taskforce, the Bahanei people seek to produce what they call the Tumbang Bahanei Indigenous Territory. The identification of the Bahanei and their Indigenous domain emerged in the context of opposition to the threat of land appropriation from a logging company, East Point Indonesia, that has been given concession by the MOF to exploit timber in areas covering 50,665 ha forests. AMAN CK has adopted particular governmental strategies to assist the Bahanei people in assembling an Indigenous land claim as an attempt to exclude their land from forest exploitation. This section highlights how AMAN CK and the Bahanei have pulled together diverse elements to make their claim and situate themselves strategically within the changing political conjuncture.

In establishing jurisdictional borders and social boundaries through mapping strategies and obtaining consent from the neighboring communities the Bahanei have pursued a process of territorialisation (Peluso, 1995). In the process they have sought to intensify the homogeneity of the Bahanei's identity through the articulation of a conservation-oriented Indigenous territory and subjectivity. In assembling this homogeneity however class, gender and ethnicity based inequalities have tended to be overlooked in order to secure and collectively mobilise the land claim (Hall, Hirsch and Li, 2011). While acknowledging other forms of exclusions in Bahanei I focus here on ethnic exclusion as the most visible tension in the land claim assemblage. 


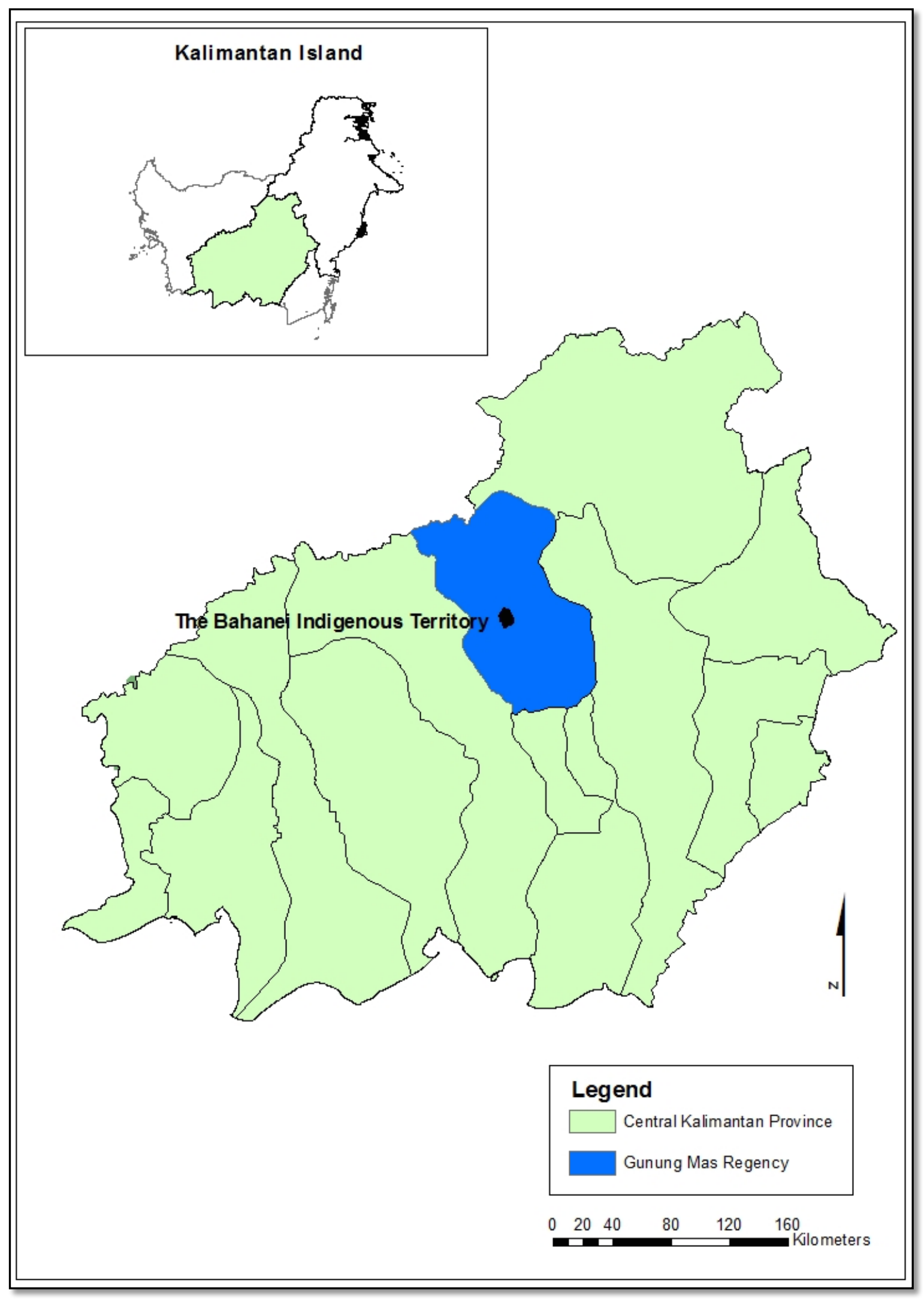

Figure 7.1 The Bahanei Indigenous territory in Central Kalimantan (Source: Rini Astuti, 2015) 


\subsubsection{Producing Indigenous Territory}

Positioning itself as a 'trustee', AMAN CK assists the Bahanei's territorialisation process by encouraging them to fit certain Indigenous characteristics AMAN has developed in Indonesia. Trustee is a position defined "by the claim to know how others should live, to know what is best for them [community], to know what they need" (Li, 2007c, p. 4). Trustees aim to empower and improve others' well-being. This definition was described well by one of the AMAN CK leaders when asked how they frame their activities in the Bahanei:

[Our activities are] an attempt to fulfil AMAN's mandates to help its community members to defend their rights to land, identity, and a life of dignity as Dayaks that have freedom and prosperity ... to realise a life that is in a harmonious relationship with nature, fellow human beings and the unseen spirits (Interview, Bredana, November 2013).

To accomplish idealistic aims, AMAN CK works through everyday practices and encounters that influence the Bahanei's dreams, passions, and actions. Various governmental technologies have been adopted to change the behaviour of the Bahanei population. Here I explore the ramifications of AMAN CK's strategies for the land claim being assembled.

In an interview with a leader of AMAN CK, he argues that they situate the Bahanei's land claim within the REDD+ Agency's agenda as a strategy to cohere support and resources that otherwise would be difficult to gain:

We were approached by the REDD+ Central Kalimantan Joint Secretariat and asked what kind of support and collaboration that AMAN CK and REDD+ institution could do together. We both have common interests in supporting communities' mapping efforts. So we [AMAN CK] decided to apply for the REDD+ grant and worked on the proposal assisted by the REDD+ Joint Secretariat. I can say that AMAN CK's position within the REDD+ agenda in 
Central Kalimantan is quite strong; we have more than 400 community members and of course it will be of interest for the REDD+ Joint Secretariat to support AMAN CK. For us [AMAN CK], I have to admit that we don't have many options for financial support for the program. We usually depend on AMAN national secretariat to finance the program. The pouring of REDD+ money in Central Kalimantan as a pilot province has provided new sources of financial and moral supports for us, that otherwise would be difficult to gain (Interview, Dormano, November 2013).

A REDD+ Agency official explained that the Agency's interest in supporting the struggle is based on the rationality of "securing tenure for successful REDD+ implementation and investment" (Interview, Kuswanto, June 2013). This mutual relationship seemingly gives advantages to the Agency, AMAN CK and the land struggles of the Bahanei. To further realize the implementation of REDD+, AMAN CK, the REDD+ Agency in Central Kalimantan and Kemitraan ${ }^{13}$ have organized a set of REDD-related activities for the Bahanei. Community representatives have participated in a workshop on Payment for Environmental Services (PES) and benefit sharing mechanisms. The workshop introduced market environmentalism rationalities to the Bahanei by introducing the concept of commodifying the intangible benefits forests provide. A series of other capacity building programmes, which were oriented at creating responsible REDD+ subjects, were held, ranging from organization management to an introduction to the principles of FPIC and safeguards (Li, 2014a).

These new initiatives, alongside existing practices and governance structures, were assembled to create Indigenous land claims. Several government regulations, such as Forestry and Village Laws, define characteristics of Indigenous people in Indonesia, however while some overlap others contradict each other. According to AMAN's own interpretation, a community has to have four main characteristics to be

\footnotetext{
${ }^{13}$ Kemitraan also known as Partnership for Governance Reform is a non-for profit organisation in Indonesia that was established through a joint initiative between governmental and non-governmental representatives, including the UNDP and the World Bank in 1999. The organisation provides financial assistance to NGOs in Indonesia through small grants.
} 
qualified as an Indigenous community. These are a definitive territory, Indigenous or adat law, adat culture, and adat structure (Nababan, 2013). AMAN CK employs these four characteristics to assist the Bahanei in articulating and assembling their indigeneity amidst the uncertainty of government definitions. The mapping practices to define Indigenous territory began in late 2012, initiated by discussions facilitated by AMAN CK activists to heighten awareness and participation within the community. A weeklong training on basic cartography was held to teach the Bahanei how to use GPS technology and to draw a map and thereby interact with OMI processes.

Two young members of the community were appointed by AMAN CK as the community's cartographers. By forming expertise, particular authority is generated, a necessary means acknowledged by an AMAN CK activist as "a mechanism to increase the community's self-confidence".

I have no higher education degree and I am just a simple rubber farmer. The furthest I have ever traveled was to Palangkaraya, the capital of the Central Kalimantan Province. Being the community cartographer, I am going next month to Jakarta for a workshop. It will be my first time ever to travel by airplane. Most importantly I am so proud because I feel like I have an important position in the community. I have a skill aside from rubber tapping that is significant for my family and my community. There is a possibility that I will also help AMAN CK to facilitate the community mapping processes in Tehang, Karetau Sarian, Tumbang Malahoi and Tajah Antang, and I will be more than happy to do it even if it means I have to stop tapping rubber for few days (Interview, Bapa Rara, October 2013 ).

This mechanism is a form of responsibilisation, a process defined by (N. Rose, 1999a) as "inculcation and shaping of responsibility for ...good order within ... the individual [and the community] by means of expert knowledges" (p. 74). The aim was to develop the Bahanei's sense of ownership of the process. The cartographers lead the process of manually drawing the map, which then was converted into a digital map by AMAN CK's staff member (Figures 7.2 and 7.3). In addition, the 
cartography experts were assigned to accompany groups of community members to record GPS points along the borders of Bahanei territory. In January 2014, representatives from the REDD+ Agency came to Bahanei to verify and validate the territorial borders with more sophisticated GPS tools. According to the REDD+ Agency's GIS expert who came to Bahanei the verification process is aimed to boost Bahanei's legal profile that will support the land claim process and the planned REDD+ activities,

I went to visit the Bahanei for a week. The aim of the visit was to verify the Bahanei Indigenous map using GPS tools that are more advanced than the tools that the Bahanei had used during the mapping processes. I verified some of the points along the Bahanei territorial borders and compared them with the data that the Bahanei had collected. I checked for the precision of the lines that they drew and found just a little deviation. I made a report and submitted it to the REDD+ Agency and I hope that this verification process can be employed to strengthen the Bahanei's attempt to obtain formal recognition for their Indigenous territory or for the mapping of potential carbons in the Bahanei's territory (Interview, Nurwajono, April 2014). 


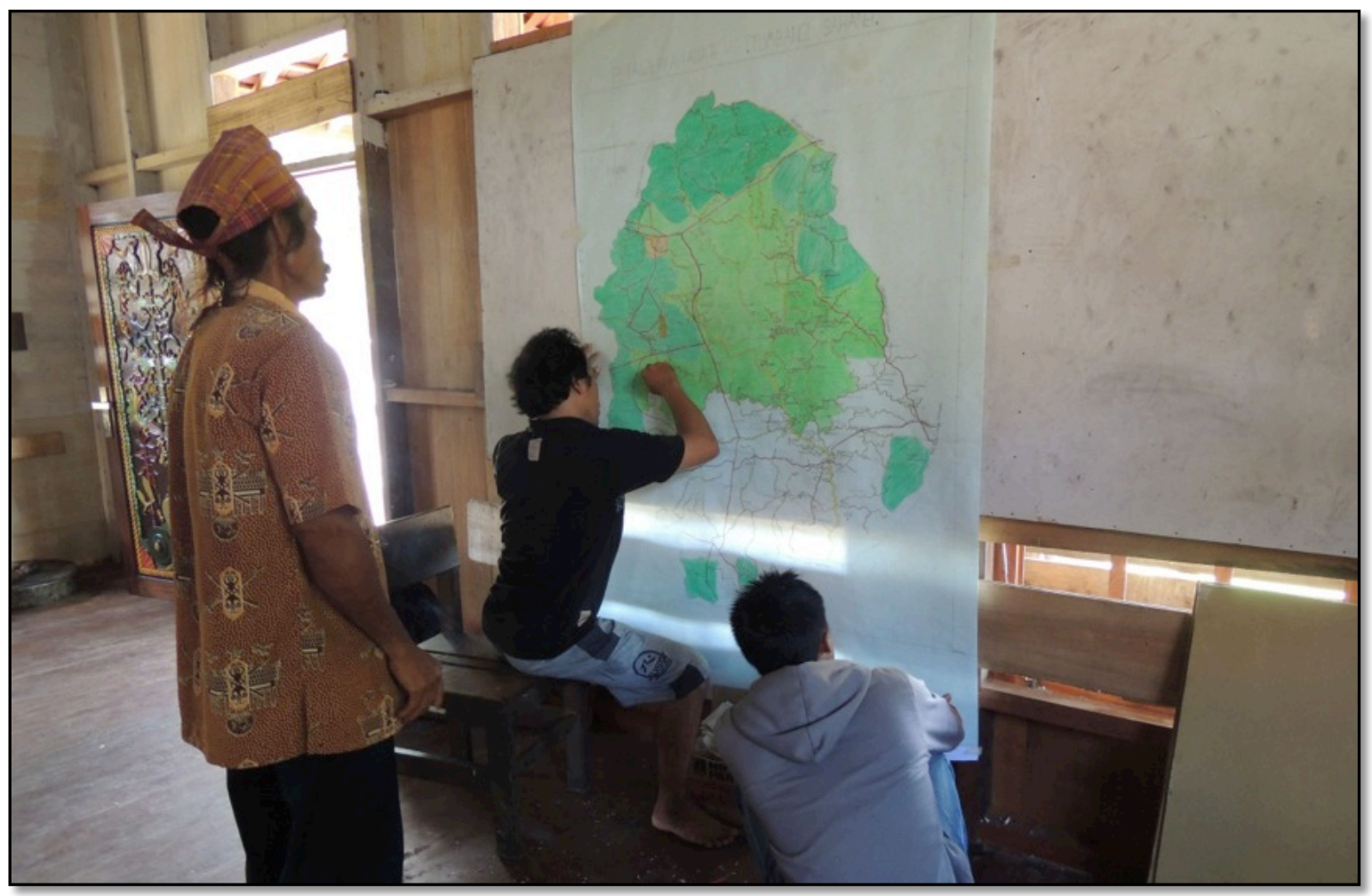

Figure 7.2 Process of manually drawing map of the Bahanei territory

(Source: Rini Astuti, 2013) 


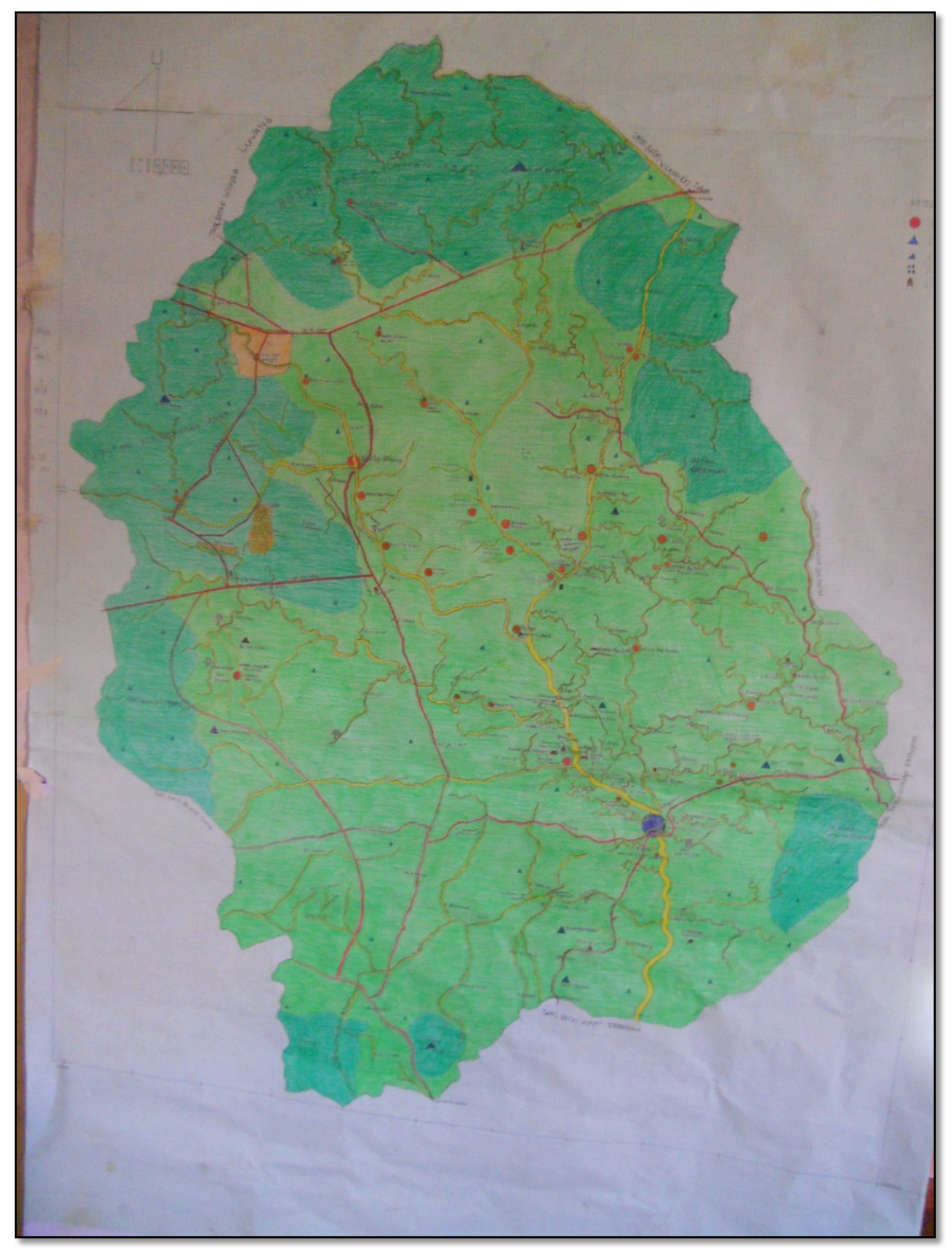

Figure 7.3 Manual map of the Bahanei territory

(Source: AMAN CK, 2013)

Despite the effort to create a sense of belonging among the Bahanei, the mapping processes were mainly led by the Mantir or Adat leader who is also the village 
secretary official. The Mantir took a major role in defining the Bahanei's borders which was seldom contested by the rest of the villagers. The Dayak Ngaju ethnic group were most active in their involvement with the mapping processes. Aside from enjoying the position as the majority in the community, almost all of the formal and informal leadership positions are held by the Ngaju. Other ethnic groups have had minimal engagement in the mapping processes. As migrants, the Banjar people came to Bahanei as rubber tappers; some married local villagers and sell their labour to work on their in-law's lands. In the context of intimate social bond enabled by the relatively small scale of the Bahanei population, the Banjar cannot freely open forests to set-up their own rubber plantations. Thus, the Banjar are deprived of having access to land unless they can afford to buy from the Ngaju or through marriage. Similar conditions apply to the ethnic Java. These differences in land access set the tone of participation in mapping processes. Therefore, while the Bahanei's Indigenous land claim counters how the state and the private sector has traditionally appropriated land, the assemblage formed intensifies intimate exclusions within the community itself, as I discuss further below (see Hall, Hirsch and $\mathrm{Li}, 2011$ )

For the Bahanei, a map acts as a type of spokesperson for them as it can be easily understood by others. Maps have the capacity to both render visible and invisible, highlighting or hiding political and technical data depending on what the creators of the map want to reveal (Scott, 1998). Bahanei maps illustrate densely forested areas as the Bahanei's sacred sites that have to be respected, prohibiting the opening of forests for non-spiritual activities. As such the map helps the Bahanei promote a particular eco-spiritual identity and highlight conflicts where sacred forests overlap with logging concessions (see eg Li, 2001). Meanwhile, the map also hides information that could have a detrimental impact on their claims, such as social data on the heterogeneous ethnic make up of the community that may detract from their land claim narrative, which assumes a relatively homogenous local Dayak tribe. Instead the mapping technology enables the necessary spatial data to be assembled to express a particular vision of Bahanei indigeneity. 
The map is one of the most important elements in assembling an Indigenous land claim. It was also an important tool to encourage action. A sense of crisis, for example, was introduced through the mapping processes when a map of Bahanei's land was overlayed on one showing the companies' concession areas. The overlap encouraged action to prevent the loss of their forests. As one of the community leaders, states:

We knew that the logging company was going to take our rubber forest, but we never realized how far the concession area was going to intrude into our land. Knowing that they would take more than two thirds of the village land just made me so angry (Interview, Bapa Rara, April 2014).

Mapping practices act as governmental technologies for AMAN CK to steer decisionmaking processes within the community. An example of this is when AMAN CK asked the Bahanei to manage their land according to the principles of forest conservation and sustainable development. AMAN CK helped facilitate this through practices of spatial ordering whereby zones were established in which particular rules are enforced.

We know that the Bahanei has all the knowledge about their land and forest. We help to manifest the knowledge into the Bahanei's map in the form of zoning system so that it will be visible to both the Bahanei themselves and the outsider. We listen to the stories told by Adat leaders about which forest is for what function and who are allowed to access them. We help the Bahanei to formulate a set of rule that can be employed to govern the forests zones and declare the Bahanei's authority over their territory (Interview, Bredana, November 2013)

The construction of zones and its categorisations were mainly defined by the Adat leaders coming from the Dayak Ngaju ethnic group, who claim to have the authoritative spatial knowledge on the territory and the legitimation powers to do so. Public consultations with the community members were held several times to 
reach consensus, however they had low attendance from non-Ngaju ethnic groups and passive participation from female members of the community.

The map of the Bahanei territory is divided into ten zones for living, rubber farming, reserve forest, conservation forest, production forest, and five types of sacred sites/sacred forests (Figure 7.4). Named using Dayak Ngaju language, each zone specifies the types of practices that are accepted and which are not (Table 7.1).

Table 7.1 Zoning system in the Bahanei Indigenous territory

\begin{tabular}{ll}
\hline Zone & Remarks \\
\hline 7.3.1.1 Himba Gita & $\begin{array}{l}\text { 7.3.1.2 A forest zone that is used to cultivate rubber } \\
\text { trees. The rubber trees are planted through } \\
\text { intercropping system with the endemic } \\
\text { species to retain the biodiversity of the } \\
\text { forest. }\end{array}$ \\
\hline Himba Lakau & $\begin{array}{l}\text { is defined as a forest zone in which no one is allowed } \\
\text { to open forests for mining, farming or hunting, as } \\
\text { there are many rare Ulin trees (Eusideroxylon }\end{array}$ \\
& $\begin{array}{l}\text { zwageri) and rare animals living in the particular } \\
\text { area }\end{array}$ \\
\hline Himba Duyun & a forest zone that is home to various medicinal herbs \\
& and big plants and where it is not permitted for non- \\
& community members to enter without permission by \\
& adat leaders \\
\hline Himba Rutas & $\begin{array}{l}\text { a forest zone that is considered sacred because of its } \\
\text { tragic history as a place where some members of the } \\
\text { community were killed during the time where the } \\
\text { Dayaknese still practicing headhunting. This forest } \\
\text { zone is prohibited for agriculture activities and is } \\
\text { communally owned by the Bahanei }\end{array}$ \\
&
\end{tabular}


Himba Tajahan is a forest area that is believed to be the place for the Bahanei's ancestor to worship their gods. The places for worship are usually signed with wooden statues and these areas are not available for agriculture activities

\begin{tabular}{ll}
\hline Himba Pukung & is a forest area that the Bahanei believed to be the \\
hahewan & home of kind spirits who help them during difficult \\
& times. This forest area can be opened for agriculture \\
& activities but have to be with caution in order not to \\
& disturb the spirits \\
\hline Bukit Kules & are hilly areas near the village that is planned for eco- \\
& tourism. Himba Cagar Eka Malan is a forest zone that \\
& is allowed for agriculture expansion and the Bahanei \\
& can cut down trees from this forest to utilize its \\
& woods \\
& are sacred sites that scattered around Bahanei and is \\
& believed to be the remains of the Bahanei's ancestors' \\
& villages or places of worship \\
\hline Kaleka & are places of worship for the Bahanei that are still \\
practicing Kaharingan, the ancestor-worshipping \\
religion. Keramat is regarded as very sacred sites and \\
usually signed with wooden mini house and statues \\
\hline an area designated for the Bahanei's neighborhood \\
which host houses, a school building, and a village \\
head office
\end{tabular}

Zoning simplifies the complexity of socio-ecological relationships into effective spatial abstractions (see Li, 2000). In this case zones were used to discipline subjects into conducting themselves in ways align with the broader political conjuncture (Li, 2000). 


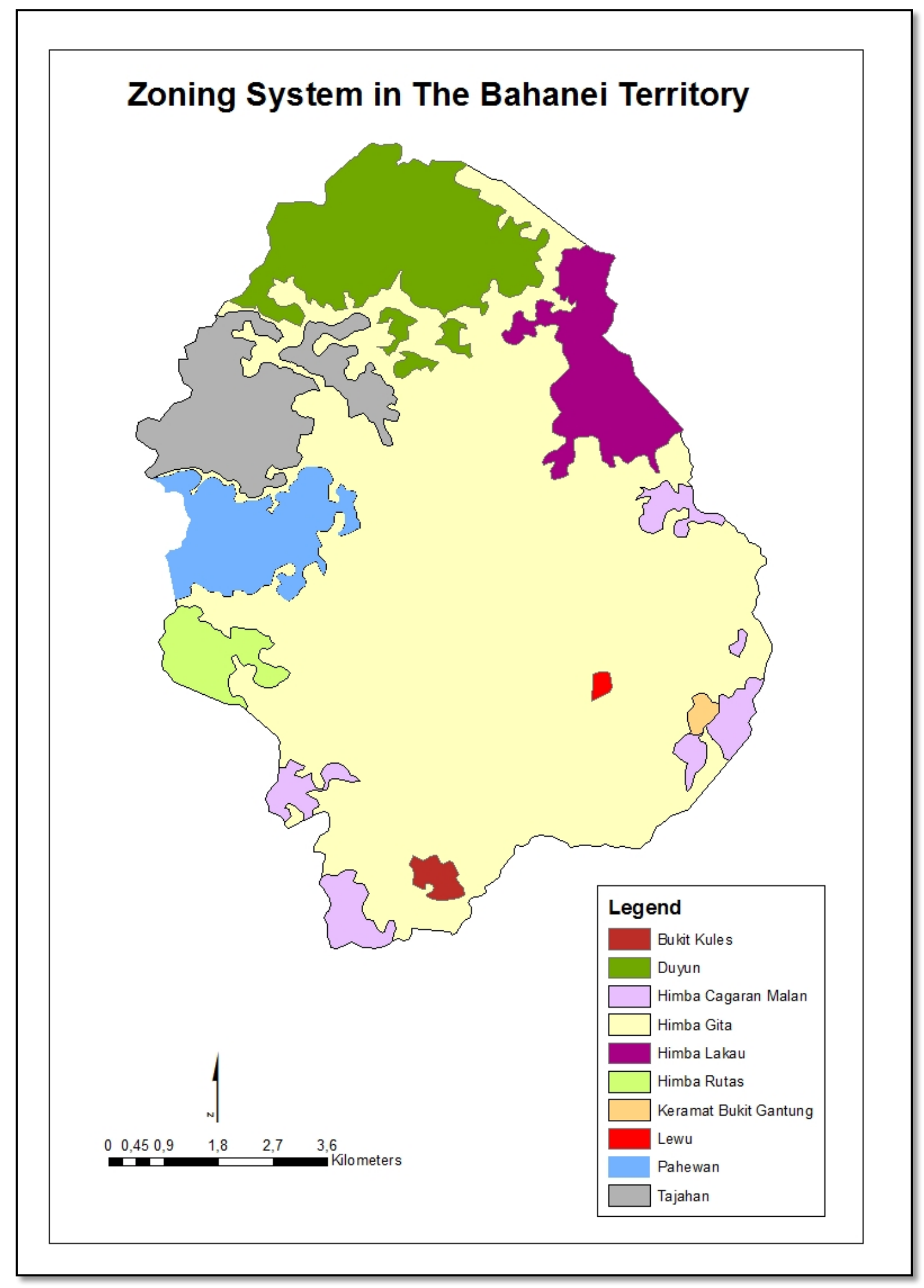

Figure 7.4 Zoning system in the Bahanei territory

(Source: AMAN CK, 2014) 
The zoning system is becoming the Bahanei's vision for sustainable land use planning, with more than $20 \%$ of its total areas being dedicated for conservation and protection. Hence, AMAN CK has successfully assisted the Bahanei in articulating their position as forest stewards, an important step for assembling Indigenous land claims in the context of REDD+ politics ( $\mathrm{Li}, 2000)$. REDD+ aims to facilitate the governing, disciplining and normalising of Indigenous people's forest conduct in ways that conform with international climate finance's interests in conservation and development (Astuti and McGregor, 2015). By aligning with this ideal, the Bahanei, through AMAN CK, has been able to successfully assemble REDD+ proponents' (eg the REDD+ Agency and Kemitraan) and their resources to strengthen the land claim (see Li, 2007b).

\subsubsection{Articulating Indigeneity}

Alongside territorialisation technologies AMAN CK also seeks to facilitate the production of a set of Bahanei adat rules to further strengthen the community's land claims (see Li, 2000). Adat rules transform on-paper ownership into territorial control in which particular ways of being are normalized while others are invalidated in different spaces (see Merry, 2001). The rules govern the territory by defining who is allowed, and not allowed, to access and use Bahanei's forest and land resources in what ways. This has necessitated series of activities oriented at the revival or reinvention of adat amongst the Bahanei, with the new rules formulated and selected according to the Ngaju's knowledge and identity. Members of the community were charged with researching different aspects of the community's relationships with the forest (Li, 2000). Two groups were formed, however, with low participation from the migrants. One group explored the history of the land and the traditions of the people. Another group was assigned to documenting the plant, animal, fish, and medicinal herbs present within the territory.

The subsequent rules discriminate between three types of users: private companies or enterprises; non-Bahanei people; and Bahanei people. The spatial ordering for private companies specifies any forms of private company activity in the Bahanei territory as trespassing unless permitted by the adat council. Any violation against 
these rules will lead to the imposition of sanctions. The particular designation of rules for the private company is according to AMAN CK activist:

A necessary weapon to fight against the land grabbing conducted by East Point that is backed by the state. We learn from the success stories of other Indigenous communities that had successfully sanctioned the private companies whose activities violated the communities' territories. Having this adat rule in place has bolstered the Bahanei's sense of confidence and tighten their Indigenous identities (Interview, Bredana, January 2014).

For Bahanei and non-Bahanei people, the rules manage the use of the natural resources by categorizing the territory into accessible and non-accessible spaces, with more restrictions placed on non-Bahanei people. The intimate social exclusions facing migrants previously described remain, however these more formal adat rules include migrants as part of the Bahanei community.

A special group of watchmen has formed to monitor the violation of adat rules, which focused in particular on trespassing of Bahanei borders. Moreover, to ensure the inculcation of the adat law, the Bahanei are encouraged to watch and monitor others in the neighbourhood (Similar to Agrawal's (2005) environmentalities). The Bahanei have been told in multiple discussions facilitated by AMAN CK that protecting the forests is as important as protecting their own body. As an AMAN CK activist explained,

If the forests hurt, they hurt. If the forests thrive, they thrive. The forestland defines the Bahanei's identity and pride. This is similar to the rest of Dayaknese identities that are signified by their connection to land. Once we lose this connection, we risk losing our identities (Interview, Dormano, October 2013).

Thus, the Bahanei are asked to report to the adat leaders or watchmen if they witness adat violations, such as, timber logging or animal hunting in sacred and protected forests. Surveillance is conducted not just by those in authority, in this 
context being the adat watchmen or community leaders, but also through more intimate monitoring by community members themselves (see Agrawal, 2005). In this way the community comes to self-govern its behaviour in order to assemble territorial claims that fit international climate finance goals (Rice, 2010; Skoglund, 2014).

To assist in the process of assembling multiple actors, AMAN CK encouraged the adoption of FPIC as an adat rule. FPIC requires every project affecting the Bahanei or their territory to get consent from the whole community. FPIC as a technology encourages what Rose (1999a) describes as autonomisation and responsibilisation. It assumes and considers the community to be capable of making appropriate choices and weighing the cost and opportunity of a particular project as an 'economically-rational' individual and collective (Milne and Adams, 2012). FPIC gives the community tools to engage in a responsible and well-ordered manner according to the norms and rules 'allowed' by FPIC principles, such as expressing grievances through consultation meetings instead of more confrontational forms of opposition ((Li, 2014a). Article 11.2 of the Adat rule specifies the requirement for FPIC implementation in the case of a private sector is planning to work on the Bahanei's forestlands.

[For the private sectors to] implement the Free, Prior, and Informed Consent Protocol that will be called FPIC for short. FPIC is a process that will ensure the Indigenous communities' ability to enjoy their fundamental rights to democratically express and give their consent or not to a particular activity, program, or policy that will be implemented upon and bring impact to the communities and their resources including land, territory, and other natural resources (AMAN CK, 2013).

In other words, FPIC can be seen as a governmental technology that enables a particular community to conduct itself as an accountable-entity within a particular project capable of deciding whether to engage or not with the opportunities being presented. As a participation technology, FPIC assumes that an affected community has the power to influence the way a particular project is designed (Milne and 
Adams, 2012; Mahanty and McDermott, 2013). The adoption of FPIC in the Bahanei's adat rules shows that, not only do the Bahanei people articulate their indigeneity through their local connections with material and spiritual worlds, but also through globally accepted Indigenous policies and discourses (Li, 2000). Thus, the adat rules connect the scattered dots required by the Bahanei to render themselves visible and at the same time dissimilar to the world outside.

The (re)formulation of adat rules, establishment of adat 'police' and the inception of FPIC are apparatuses of indigeneity. Combined with the territorialisation processes initiated through the mapping technologies they allow for a particular expression of indigeneity that is shaped by, and most likely to be recognised and rewarded by, the opportunities associated with Indonesia's new political conjuncture in forest governance. However they also consolidate, and in the process restrain, a particular homogenous vision of indigeneity that fits the imaginary Indigenous community promoted by REDD+ developers.

\subsection{Tensions and Fractures}

The forms of governmentality and assemblage described above do not guarantee Indigenous claims to land. Instead they reveal some emerging strategies of territoriality and ways of performing indigeneity that reflect Indonesia's new political conjuncture. However, old political ecologies are hard to shift, and there is a tension between national policy and local implementation. The Bupati, or district level governor, for example, is officially responsible for legally endorsing adat forests and plays an important role in ensuring local efforts are recognised in national initiatives. However the Bupati often has other interests, including the economic development of their region and funding re-election campaigns, both of which can rely on exploiting, rather than protecting, natural resources. Incorporating the Bupati into Indigenous land claims assemblages has proved a difficult task. While the elected Bupati is currently in prison for a corruption case involving the issuance of illegal forest concessions, the interim official remains more supportive of extractive industries than Indigenous land claims. In an interview, a 
district official expresses his view by articulating the local political dynamics that Indigenous land assemblages face:

How could the Bupati endorse a mapping process that will be followed by all Dayak people in Gunung Mas District. If all the land is claimed by them, then where would the Bugis and Banjar people have to go? They represent a significant number of voters in local elections. The Bupati doesn't want to upset them (Interview, Poniman, April 2014).

AMAN CK's effort to codify and modify how the Bahanei relate to one another and to the forest through a revitalised adat is very much shaped by fractures and tensions within and outside of the community. Local artisanal gold miners, for example, initially opposed the implementation of adat rules, fearing it would restrict their activities. As the price of rubber has been plummeting for the last couple of years, many members of the Bahanei community supplement their incomes from mining gold sand along the Bahanei River. There are around ten mining machines owned by elite Ngaju who can afford to buy the machine and the fuels required. Each machine requires four to six miners to operate - mostly migrants and poorer Ngaju who have smaller rubber plantations.

The mining processes, which use mercury to filter river mud for the gold sands, have caused environmental problems, such as river siltation and the poisoning of the water body. The government through the Ministry of Energy and the MoF are labelling the artisanal small-scale mining, particularly when conducted in forest areas, as illegal and destructive activities (Spiegel, 2012). Thus, forest rangers and the police can prosecute and put local artisanal miners in jail. These unsustainable practices also clash with the conservation subjectivities AMAN CK is promoting within the community. For now, AMAN CK has convinced the miners that they will have more freedom and opportunity for mining when Bahanei territory is given legal status as an Indigenous domain. AMAN CK argues that legal endorsement of Bahanei territory will allow the Bahanei to govern the land and its resources without fear of being caught by the police or forest rangers. Once the territory is 
legally endorsed a practice of sustainable mining may be introduced (for the context in Suriname see Haalboom, 2011).

However, there are clear tensions here as some Bahanei resist the green subjectivities being thrust upon them. In an interview with one of the adat leaders involved in a different community-mapping struggle, the leader saw Indigenous land claims as an opportunity to increase Indigenous profits from extractive industries (Interview, Bapa Zuli, April 2014). For this leader, the map is a tool for increasing profits from expanding palm oil, rather than a tool to protect traditional territories from them.

These fractures created by these non-performing Indigenes reflect broader subtle tensions. While practices of territorialisation play a vital role in strengthening claims to land and codifying local Indigenous identities the process is contributing to ongoing intimate exclusions - everyday practices that exclude some from the benefits others are receiving (Hall, Hirsch and Li, 2011). Exclusion is inevitable when priviledged access and ownership to benefits is granted to a particular individual or collective. A Bahanei member reflects on the intimate exclusions in the case study area:

One of the elders of the community questioning my motive of being active in AMAN CK's activities ... he provoked others to hate me since I am not originally from Bahanei and talked behind my back ... he even undermined the hard work I have done for the community and he wanted my position [in the] community's committee to be replaced by someone else (Interview, Bapa Nandita, April 2014).

Culture, local political tensions and relational power play important roles in facilitating such kinds of intimate exclusions (Hall, Hirsch and Li, 2011). As such the practices of governmentality and assemblage can exacerbate inequalities in pursuit of broader collective goals. The market environmentalism that underpins the new political conjuncture can simplify and homogenise communities as "black boxes" who can be packaged in particular ways for carbon investors (Milne and Adams, 
2012, p. 147). Homogeneity simplifies the political and technical configurations needed to 'modify' communities who are constructed as 'economically-rational' actors capable of responding to the contracts required by REDD+ and other mechanisms of market environmentalism.

These exclusions raise concerns Indigenous land claims may be experienced as Indigenous land grabs by those who are excluded. Indigenous communities favoured by the new political conjuncture and empowered by Indigenous and environmental networks may attempt to grab land from neighbouring communities that fit less comfortably within idealised visions of indigeneity. Within communities the process of assembling land claims may involve intimate exclusions whereby a particular homogeneous indigeneity is performed that results in intensification of community exclusions rooted in ethnicity, class and gender inequalities (Hall, Hirsch and Li, 2011). As Hall et al (2011) argue in their analysis of exclusion's double edge that "every counter to one discourse of exclusion necessarily proposes exclusion on other grounds" (p. 171). At this local scale an empowering land claim for some may be experienced as a marginalising land grab by others.

A land grab is characterized within scholarly articles as involving large scale changes in land use and land property relations, powerful private / public partnerships, food, fuel, mineral and conservation focused activities, and involving "the restructuring of rules and authority over the access, use and management of resources" (Fairhead, Leach and Scoones, 2012, p. 239) that often intensify local exclusions and marginality (Borras et al., 2011; Corson, MacDonald and Neimark, 2013; Margulis, McKeon and Borras, 2013). In contrast Indigenous land claims are associated with specific small-scale territorial claims on land and its resources based on collective rights, historical connections to place, discourses of injustice, in opposition to powerful state and private sector actors (Peluso, 1995; Hall, Hirsch and Li, 2011). Whereas land grabs often marginalise those that do not fit within a vision of improved resource use for economic development, land claims are more likely to prioritise "ethno-territorial" rights based on place-based homogenous "green" subjectivities of connection and belonging that, similarly, not all will fit (Hall, Hirsch 
and Li, 2011). Hence land claims, like land grabs, risk intensifying local exclusions and marginality if they are insufficiently responsive to community diversity.

As a trustee, AMAN CK has been slow to address the intimate exclusions faced by migrants. Moreover, neighboring communities around the Bahanei question the basis upon which the borders are determined and claims made. For these neighbors, the struggle to establish Bahanei territory is seen as a local land grab, threatening their access to land and forest resources such as timber. Without careful consideration about these potential tensions, there is a risk that those communities that are not AMAN members and cannot perform the green Indigenous ideals valued in the political conjuncture will be further marginalised. As Pratt (2012, p. 178) observes, "Indigenous communities are never the intimate and cohesive social units we anticipate". In Indonesia forest communities have become increasingly heterogeneous in their ethnicity characteristics and livelihood practices due to transmigration policies during the New Order regime that brought million of Javanese to the outer islands of Indonesia (Hall, Hirsch and Li, 2011). Moreover, the presence of private investment in the forms of mining and plantation have further altered Indigenous livelihood practices as many move from forest dwellers into laborers. REDD+ then presents the possibility that Indigenous communities that perform in ways that fit REDD+ imaginaries will benefit more than those that don't. This increases the vulnerabilities of the latter, which are often higher compared to the former (Li, 2014b), and may reify an Indigenous definition that they may never be able to perform.

\subsection{Conclusion}

In this chapter I have argued that three inter-related processes have created a new political conjuncture in forest governance in Indonesia. The Constitutional Court decision recognising Indigenous land claims, the pursuit of carbon economies through REDD+, and the national One-map initiative that seeks clarity on land ownership, have all combined to provide new opportunities for Indigenous land claims. There is renewed interest in Indigenous peoples, new resources and technologies devoted to recognize their claims, and new Indigenous geographies 
being produced. Governmental mechanisms are contributing to socio-ecological assemblages that enable Indigenous propositions that challenge the status quo.

At the core of the Bahanei assemblage are Indigenous groups, AMAN CK, AMAN, the REDD+ Agency, REDD+, the Constitutional Court, GPS, the Bahanei's map, Kemitraan, OMI, the forest moratorium, expert subjectivities, gold miners, Indigenous performances, FPIC, adat rule, forests, rubber prices, community consultations, carbon traders, donors, and, hopefully, local authorities. More broadly there are the active engagements of environmental and Indigenous activists, researchers, national and international governments, and donors in steering the direction of REDD+ policy-making and its implementations toward inclusiveness and socio-ecological justice. There can be little doubt that the previous status quo, which favoured state and private interests in extractive industries, is being challenged in new creative ways. This assemblage is however provisional, loose, disjointed and responsive to shifting political developments - and what this chapter describes here is constantly changing. Capturing this dynamic assemblage of forest political conjuncture in the academic writing process, however, is problematic and difficult given the pace of change on the ground. In conducting this research, I have to adapt to this situation of researching "a moving train" with flexibility and rigor (see Chapter 3).

This chapter has also shown that assembling Indigenous land claims through the production of Indigenous territory and the articulation of particular green Indigenous identities are fraught processes that are changing Indigenous subjectivities and human-forest relationships at local scales. The type of Indigenous territory being produced bears the imprint of romanticized visions of indigeneity circulating within REDD+ communities, as well as the governmental tactics and hopes of Indigenous rights NGOs such as AMAN. The chapter's analysis suggests that the tentative alliance between Indigenous groups and REDD+ proponents is producing opportunities for Indigenous land claims whereby land is reclaimed from the state and extractive industries. At the same time however local Indigenous land grabs based on powers of intimate exclusion and performance of particular Indigenous green subjectivities are creating frictions and forms of exclusion within and between communities, favouring those who can perform these quite limited 
subjectivities over others. Migrants, miners, and others interested in converting forests to other uses risk being excluded from new assemblages and the potential benefits.

Ensuring that Indigenous land claims are not experienced as land grabs by vulnerable groups requires acknowledging diversity and devoting attention to overcoming forms of intimate exclusion, based on categories such as ethnicity, class, and gender (Hall, Hirsch and $\mathrm{Li}, 2011$ ). Incorporating more heterogeneous understandings of forest communities into assemblages currently based on homogenous articulations of indigeneity is a necessary next step in pursuing fair and just outcomes from the new political conjuncture. Much will depend on the governmental skills and approaches implemented by trustees steering these processes, in this case AMAN, to form assemblages that enable, rather than constrain, diverse local Indigenous aspirations. However it also requires greater awareness of heterogeneity amongst the broader actors shaping the politics and opportunities for forest carbon economies. The imaginary REDD+ Indigenous identity circulating amongst donors, investors, developers, policy makers, law makers and technologists associated with REDD+ is both enabling and constraining at the same time, influencing the political opportunities and strategies of others in the assemblage. The imaginary Indigenous identities are legitimized and facilitated by the interests of state and non-state actors in producing governable spaces and environmental subjectivities that enable participation within market based environmental governance. Moving beyond rigid stereotypes by recognising local complexity and diversity may slow such efforts, but expand the possibilities for more just outcomes that prevent the potentially slippery and unwanted transition from Indigenous land claims to Indigenous land grabs. 


\section{Conclusion}

"Sometimes we simply have to keep our eyes open and look carefully at individual cases - not in the hope of proving anything, but rather in the hope of learning something!"

Hans Eysenk (1976)

\subsection{Introduction}

The acts of governing human - forest interfaces through REDD+ are far from straightforward. Rather, as explored in this thesis, as an art of government REDD+ is developed, translated, shaped and contested in many ways. A new political conjuncture in forest governance is emerging, driven in part by what Indonesia's REDD+ proponents call "Beyond Carbon, More than Forest". Drawing on three case studies, I have argued throughout the thesis, that this particular characteristic of Indonesia's REDD+ has modulated the way REDD+ governmental technologies are being produced, applied and contested. To this end, I have presented the findings of the research in three chapters, each of which addressed research objective one to examine how REDD+ governmental technologies are being developed, applied, and contested with what effects, within three different case studies. In what follows I will respond to research objective 1 and summarize the findings that have been presented in Chapters 5, 6 and 7. Following this summary, I will extend the discussion on REDD+ governmental technologies by employing the not-quite neoliberal nature framework to answer research objective 2 (de Freitas, Marston and Bakker, 2015).

During the three years of this $\mathrm{PhD}$ there have been three changes in the government institution charged to implement REDD+ in Indonesia: the REDD+ Taskforce (2010 2013), the REDD+ Agency (2014), and the Directorate General of Climate Change under the newly merged MOEF (2015 - present). The frequent changing of the REDD+ institution demonstrates the dynamic yet shaky ground in which 
governmental strategies are devised. The recent decision by President Jokowi to dissolve the REDD+ Agency within the MOEF suggests the program may fade. However, several REDD+ related influential programs are still being implemented as forest reform programs, such as OMI - including the forest moratorium. Yet several of the applications for REDD+ implementation have been finally granted by the MOEF. The latest update is the release of Rimba Makmur Utama's project design document, a private REDD+ project situated in Central Kalimantan (Rimba Makmur Utama, 2015). The document states the annual potential sequestration of 8 million tons of carbon. However, responses from the news media and oppositional NGOs were unusually quiet. This raises questions as to whether REDD+ opponents' opposition based on the perception that REDD+ is a neoliberal program has changed.

This chapter engaged this changing dynamic by addressing research objective 2 to examine REDD+ governmental technologies using a not-quite-neoliberal nature framework in order to identify constraints but also remain open to strategic and progressive possibilities embedded in this mechanism of forest governance reform. The section will discuss cross cutting elements that emerge throughout the three case studies that enable the translation of REDD+ neoliberal rationality into not-quite-neoliberal governmental technologies by "productively explor[ing] possibilities for emancipatory politics" within forest governance (de Freitas, Marston and Bakker, 2015, p. 242). I will then outline the contribution this research makes to both the body of knowledge on neoliberal nature and to the understanding of REDD+ as an art of government. The chapter concludes with some notes on the future direction of research and some final thoughts.

\subsection{Summary of Findings}

The first objective of the research is to examine how REDD+ governmental technologies are being developed, applied, and contested with what effects within three different case studies. 


\subsubsection{Research Objective 1(a)}

To examine a selection of governmental technologies being developed and applied by the REDD+ Taskforce to mainstream REDD+ in Indonesia particularly at the national scale. The case study focuses on the participatory technologies being developed, the politics surrounding these technologies and the new subjectivities emerging.

In Chapter 5, I have discussed three governmental technologies produced by the Taskforce to normalize REDD+ as an art of forest government in Indonesia. These governmental technologies work by communicating, visualizing and engaging forest carbon as the main rationality for REDD+ programs. The technologies seek to produce REDD+ subjects and encourage people to conduct themselves in ways that favour global climate governance. In addition, however, I found that environmental and Indigenous activists have shaped REDD+ implementation so that it is more socially progressive by focusing on more than conserving carbon. Governmental technologies to communicate REDD+ were developed using specific concepts and language such as: additionality, leakage, landscape and jurisdictional approaches. Each of these concepts is supported with scientific knowledge that legitimizes their use in governing human and forest interfaces (Holmgren, 2013). Scientific concepts are applied throughout the Taskforce's documents and policies to introduce new ways in constructing and valuing forest and land use. I argued in Chapter 5, that these governmental technologies, like the scientific forestry that was originally imported to Indonesia during the colonial era from Germany (Hölzl, 2010; Siscawati, 2012), risk marginalizing those without access to scientific knowledge while advancing those who have.

The Taskforce bolstered carbon visibility through mapping technologies to render forest carbon as an entity that can be managed and governed. AMAN also employed this technology to render visible Indigenous territories by overlaying them with forest and carbon maps. This shows that REDD+ governmental technology can be coopted and shaped to serve non-carbon interests. To engage wider REDD+ stakeholders the Taskforce developed their governmental technologies through 
processes of participation and consultation. The findings show that technologies to engage stakeholders were often formalized as part of the structure of the REDD+ institution, such as in the formation of working groups in the Taskforce and allocation of specific representation from Indigenous experts in the structure of the REDD+ Agency. The technologies can be seen as attempts to render technical political issues by shaping forms of engagement that incorporate activists as "insiders" rather than oppositional “outsiders" (Backstrand, 2004; Li, 2007c).

My analysis shows that through these technologies of engagement, new pro-REDD+ subjectivities are emerging. Activists who were directly involved with the work of the Taskforce and the REDD+ Agency as part of their expert staffs or consultants have found themselves exposed to the complexities of forest governance. Activists were becoming less utopian and more permissive toward the government's slow response as they learnt the "reality" of complex bureaucracies. Some activists adopted subjectivities as REDD+ experts and represented the government when engaging civil society colleagues who were positioned "outside" of the government system. While this risk activists being depoliticized, the engagement also produce new spaces for maneuver in which activists employed REDD+ governmental technologies to pursue social and environmental justice ends (Mulyani and Jepson, 2013; Agung et al., 2014).

The REDD+ Taskforce went some way in normalizing carbon rationalities through these technologies. They generally drew upon disciplinary and neoliberal environmentalities to motivate the changes in the conduct of the forest stakeholders (Fletcher, 2010). The findings in Chapter 5 demonstrated, however, that attempts to govern forest stakeholders' conduct is not an easy endeavour as they are also actively shaping and contesting the governmental technologies that targets them. Motivated by their particular interest forest stakeholders responded differently to REDD+ governmental technologies.

In Chapter Five, I described the way palm oil companies rejected the implementation of forest moratorium policy by employing the discourses on national sovereignty and economic growth. Opposition to REDD+ also came from 
several environmental NGOs, such as WALHI, that were not politically sympathetic toward the neoliberal rationalities underpinning REDD+ market mechanisms. The findings show that contestations were not only based on disagreement about REDD+ contents and policies but also based on resentment toward the institutional standing of the Taskforce and later the REDD+ Agency as the new player in the forestry and land governance system. Affected ministries, such as MOF and House of Representatives have expressed their disagreement to the formation of an ad-hoc institution to manage REDD+ by continuously questioning the Taskforce's authority and capacity in managing forest related programs and policies (Luttrell et al., 2012). Opposition to REDD+ strategies contributed to the dissolution of the REDD+ Agency in 2014. The case study shows that the production of new governmental technologies can be undone and reshaped by existing political ecologies.

\subsubsection{Research Objective 1(b)}

To analyze the production and application of OMI as a governmental technology employed to produce governable space for REDD+ investment. The case study focuses on the design of $\mathrm{OMI}$ and the selective engagement by activists seeking to reorient OMI towards more progressive forest governance.

Drawing on three elements of OMI: the Moratorium, One Database, and One Standard, I showed how REDD+ proponents problematize current forest arrangements as irrational (Li, 2007c). OMI emerges as a national initiative that requires all spatial policies and related decision making to refer to maps issued only by GIA (Samadhi, 2012). In the context of forest governance, it means all the decisions related with forest areas have to refer to maps of forest cover that are officially acknowledged by GIA. Findings in Chapter 6 demonstrated that each technical ministry and provincial/district government used to have its own version of a map of state forest area when issuing forest licenses, resulting in concession overlaps, land tenure conflicts, environmental degradation, and forest corruption (Dermawan et al., 2011). Based on the findings, I argued that OMI aims to control the production of forest spatial information and provides a greater role for national government agencies in shaping where forests are, how forests are used and by 
whom. Chapter 6 illustrated that implementing OMI is becoming REDD+ proponents' (the Taskforce and UKP4) priority as REDD+ can only be effectively implemented in a conflict free landscape. OMI is then employed as the Taskforce's main governmental strategy to produce governable spaces for carbon investment.

Chapter 6 explained how the forest moratorium policy was firstly implemented as a governmental technology to temporarily halt the issuance of forest concessions. Aimed to govern private sector actors and government officials, Chapter 6 discussed how the technology performs as a sovereign environmentality by establishing regulations and punishing those who do not adhere. Drawing on a process of simplification the complexity of Indonesia's diverse forests were divided into primary natural forest and secondary forest (Scott, 1998; Murdiyarso et al., 2011). As Chapter 6 has argued, the classification provides scientific legitimacy for the government to decide what is included and excluded in the moratorium. By stating that the policy will be enforced in peatland and primary natural forest only, the government manufactured an approach that protected private sector interests while appearing to be progressive and non-political (Li, 2005).

By giving temporary pause, the moratorium is expected to provide enough time for the forestry authorities to address the messiness of forest governance - in particular problems related with spatial arrangements. Despite its simplification and apolitical characteristics (Scott, 1998; Li, 2007d), I argued that the implementation of the moratorium has facilitated a new level of data transparency enabling more informed contestation from civil society. Activists engaged with the moratorium used the language and means provided by the REDD+ proponents to monitor and highlight breaches. The publication of the Indicative Moratorium Map and the opportunity to express contestation and grievance were widely employed by NGOs to problematize and publicize environmental violations by private sector actors.

The One Database technology sought to create one registry of forest concessions that will consolidate and store basic legal and spatial information, such as, the location of the concessions and its legal documents. I argued that this governmental technology is aimed at boosting data transparency and availability while also 
establishing a central point of knowledge and truth about Indonesia's forests (Dean, 2009; Aicher, 2014). Findings showed that governing of practices of collecting, reviewing, digitizing, and archiving spatial information in Indonesia is seen as an essential step in disciplining spatial data users and producers. Chapter 6 illustrated for example that by simply relying on satellite technologies, the One Database enables a better monitoring system by highlighting which institution or company is responsible for a particular plot of forest. Thus, Chapter 6 proposed that One Database could perform as a surveillance mechanism for policing concession holders not to violate regulation. It provides a platform for forest governance transparency that enables more informed contestation and critiques while encouraging forest users to conduct their conduct according to government goals (Foucault, 1991a). The chapter also, however, exposed the messy actualities of this seemingly simple governmental technology implementation at the local level by describing contestations coming from local government officials seeking amnesty for past offences.

The third governmental technology outlined in Chapter 6 is 'One Standard'. This technology regulates the production of spatial data to follow a certain technical standard that have been defined by GIA (Samadhi, 2012). The standard ensures the map's technical quality and compatibility with the state's cartographic convention. Chapter 6 provided an example of GIA's attempts in fostering the production of participative mapping standard. The participative mapping standard also covers the governance of Indigenous mapping practices and is expected to perform as a disciplinary mechanism intended to ensure the adherence of Indigenous maps with the state's geospatial criteria (Peluso, 1995; Tahilramani, 2013). As argued in Chapter 6, Indigenous activists are critically engaging with One Standard as a means of making Indigenous land claims more visible in land use policy making. Indigenous activists subverted GIA's technical fixes to accommodate principles of counter mapping (Hodgson and Schroeder, 2002; Wainwright and Bryan, 2009; Pramono, 2013). Accordingly, one of the most discussed issues in OMI is the expectation that it will finally clarify tenure conflicts and bring recognition and justice to Indigenous communities. 
Chapter 6 have outlined three governmental technologies that have emerged as part of the REDD+ strategies to produce forest spaces and knowledge that fit the requirements for forest carbon investment. I argued in Chapter 6 that most of these technical fixes attempt to modify the conduct of concession holders and government officials based on the processes of simplification, surveillance and rendering technical. However, findings showed that these technologies have also created hybrid spaces for activists to pursue progressive possibilities, in which REDD+'s neoliberal nature rationality co-exists with a broader purpose to seek justice for Indigenous land rights and environmental protection.

\subsubsection{Research Objective 1(c)}

To track how REDD+ technologies are contributing to the formation of a new political conjuncture in forest governance and to subsequently trace the effect of this new conjuncture to a particular Indigenous land claim assemblage in Central Kalimantan.

The third case study illustrated the impact of REDD+ governmental technologies on the process of assembling an Indigenous land claim in the Bahanei community situated in upland territory of Gunung Mas District, Central Kalimantan. I have outlined the new emergence of a new political conjuncture in chapter 4 - shaped by three elements: the implementation of REDD+; the One Map Initiative; and the Constitutional Court decision Number 35/2013 that acknowledged the Indigenous community's ownership to adat forest. The new conjuncture showed the shift in Indonesia's forest governance where Indigenous rights discourses are becoming an important component of rhetorical debates and practical policies. As explained in Chapter 6, this shift has driven Indigenous mapping efforts undertaken by AMAN and other activists and community members covering millions of hectares of contested forest land. Indicative of the changing politics of forests, such actions are not seen as counter-claims against the interests of the state (for counter mapping see (Peluso, 1995), instead they attract support and financing from REDD+ authorities. 
Based on this new conjuncture, I argued that the mapping and claiming of millions of hectares of Indigenous land could potentially be experienced as Indigenous-styleland grabs at the local scale. However, instead of "powerful" actors such as big companies being the grabbers, local communities become divided into those who can perform or meet the requirements for assembling an Indigenous land claim, and fit the romanticized version of indigeneity supported by REDD+ authorities, and those that do not. I proposed thereafter, that to avoid the Indigenous land grabs, REDD+ authorities need to acknowledge diversity and give attention to overcoming forms of intimate exclusion that REDD+ might unintentionally exacerbate. Chapter 7 has argued that "incorporation of more heterogeneous understandings of forest communities into assemblages currently based on homogenous articulations of indigeneity is a necessary next step in pursuing fair and just outcomes from the new political conjuncture" (Chapter 7, p. 215).

Furthermore, in examining the grounded actuality of the above political conjuncture, Chapter 7 examined the two main governmental technologies produced by the Bahanei to assemble a land claim, these are, territorialisation and the performance and articulation of Indigenous subjectivities. In producing Indigenous territory, the Bahanei employs mapping technology to render visible the threat of land appropriation from a logging company. The map of Bahanei territory is overlaid with the map of logging concessions and is employed as a weapon to advocate for Indigenous land recognition. Facilitated by AMAN CK, the Bahanei received attention from the REDD+ Taskforce and gained political and financial support as a result. To secure support from the REDD+ Taskforce, AMAN CK facilitates the production of green Indigenous subjectivities to align the Bahanei with wider REDD+ proponent interests in producing governable space and subjects for REDD+ implementation. As discussed in Chapter 7, the articulation of green Indigenous subjectivities were made through zoning technologies and the production of Adat law. Both of these tools of government aim to discipline the Bahanei and govern the relation of outsiders to Bahanei land and forest resources. The Adat law encourages green subjectivities among the Bahanei and legitimizes the implementation of surveillance technology through the formation of "Adat police". 
I argued, furthermore, that the production of the Bahanei map and Adat law have enabled the implementation of sovereign form of governmentality by forbidding others to access Bahanei's land and forest resources without proper permits. These two governmental technologies work together in articulating the indigeneity of the Bahanei. The sovereign governmentality, however, was contested by the neighbouring communities whose access to land was being restricted and marginalized by the new territorialisation technologies. I argued in Chapter 7 that "while practices of territorialisation play a vital role in strengthening claims to land and codifying local Indigenous identities the process is contributing to ongoing intimate exclusions - everyday practices that exclude some from the benefits others are receiving" (Chapter 7, p. 211). Despite these risks and challenges, Chapter 7 has clearly showed that the new forest political conjuncture, which has been influence by REDD+ governmental technologies, have provided new opportunities for progressive changes.

\subsection{REDD+: Beyond Neoliberal Nature Rhetoric}

This section seeks specifically to address research objective 2 that is to examine REDD+ governmental technologies in Indonesia from a not-quite neoliberal nature framework. Following de Freitas, Marston and Bakker's (2015) framework, I discuss cross cutting elements that emerge throughout the three case studies that enable the translation of REDD+ neoliberal rationality into not-quite-neoliberal governmental technologies. As has been argued throughout this thesis, REDD+ governmental technologies are produced as technical fixes to address existing sociospatial problems. However they have also given rise to stronger public participation mechanisms and improved decision making practices. Adopting de Freitas, Marston and Bakker's (2015) steps in assessing not quite neoliberal nature projects in Latin America, I assess four cross cutting themes that emerge throughout the three case studies that can help in understanding Indonesia's REDD+ governmental strategies as an assembly of calculated techniques that are modulated by place-based discourses, politics, interests and agency of actors. 


\subsubsection{Flexibility and Ambiguity of REDD+}

In this section I discuss flexibility and ambiguity in REDD+, which was clearly apparent in a Global Partnership Meeting, a workshop organized by the UN-REDD in 2013 in Palangkaraya, Central Kalimantan, where participants could not hide their puzzlement as they went from one site of REDD+ activities to the next. I was involved as a participant in the field trip organized as part of the workshop. The first site shown by the organizing committee was a village in which we met with groups of women who had learned to weave baskets and other handicrafts using rattan gathered from nearby forests. The second site was a large plot of wet peatland with a small patch of rice cultivation. According to the group of farmers that we met, it was a variety of rice that can live in wet peatlands. Both of these groups, the women weavers and the peatland farmers, were the beneficiaries of the REDD+ readiness fund distributed by the REDD+ Taskforce. The final site was a massive bamboo building that is called as the Centre for REDD+ Knowledge Learning. This bamboo hall was built using the REDD+ readiness fund from the Government of Norway which functions as the hub for REDD+ activities and training in Central Kalimantan, the first pilot province for REDD+ in Indonesia.

The diverse activities seen in the fieldtrip were not the type of activities that the participants of the workshop expected to define REDD+. Questions emerged throughout the discussion sessions on the diversity, highlighting the surprise of the workshop participants. Some of them expressed appreciation for the flexibility that the REDD+ Taskforce created to include small scale livelihood empowerment activities for local communities in broader REDD+ programs and policies. Others, however, have expressed concern over whether these activities would lead to real carbon conservation mechanisms. Justifications were of course provided by the REDD Taskforce experts team on the relation of these diverse activities with avoiding deforestation and forest degradation.

This event reflects the flexibility and ambiguity of REDD+. As a new mechanism in environmental governance, REDD+ is still being developed and thus its pilot 
activities are rather diverse depending on how REDD+ is being translated into sets of activities by its proponents. This flexibility opened up opportunities to create governmental technologies that do not necessarily correspond to carbon conservation and offsets. Thus, the flexibility has created ample room for manoeuvre in which activists can actively repurpose REDD+ initiatives to better fit notions of social and environmental justice.

This flexibility avoids a binary division whereby REDD+ "is either to be rejected as a neoliberal 'Trojan horse' or embraced as the new market panacea” (McElwee, 2012). Hence, despite REDD+ being designed to be a neoliberal instrument at one level, its translation in the three case studies discussed in this thesis has demonstrated to be a hybrid of neoliberal and not-quite neoliberal nature projects. This flexibility attracted significant attention and engagement from diverse non-state actors. This implies that the success or not of REDD+ mainstreaming as an art of governing human and forest relations lies in the socio political impacts of its application rather than in its functioning as a merely market mechanism (for the context on PES see eg Mcafee and Shapiro, 2010; McElwee, 2012; Milne and Adams, 2012; McElwee et al., 2014). This degree of flexibility and ambiguity in translating REDD+ may become narrower in the future, particularly when forest spaces are locked into particular contracts. However for the period examined ambiguity and flexibility provided possibilities for progressive engagement and change.

\subsubsection{Fluid and Multiple Subjectivities}

The second cross cutting element that characterized Indonesia's REDD+ as a notquite neoliberal nature project is the productive tension arising out of the state and society relationships (de Freitas, Marston and Bakker, 2015). Activists actively negotiate the relationship through the embodiment of multiple subjectivities that enable them to work "with(in), against, and beyond the state" (de Freitas, Marston and Bakker, 2015, p. 243). As discussed in Chapter 5, activists' fluidity in occupying "insider" positions as part of government's expert team, while maintaining active engagement with activism, has helped in bridging communication and building productive tensions between actors in both camps. While assuming positions as 
experts for the Taskforce, activists have the opportunity to directly modify REDD+ neoliberal rationality by further articulating visions for progressive forest reform. An example of this is the engagement of activists who work in the REDD+ Taskforce in convincing the broader REDD+ proponents that success will depend on the capacity of the program to fundamentally change forestland governance. This includes providing clarity over where forests are and who has ownership and access to them, and resolving conflicts over Indigenous tenure rights.

Aside from providing direct access to the REDD+ program and policy making, the adoption of expert subjectivities has enabled activists to learn and practice the language of bureaucracy. This is important in enabling activists to translate their socio environmental justice interests in languages that will attract government support while appearing to be non-political. This contradiction is double edged: on one side, activists can risk being depoliticized, while on the other side, there are wider opportunities to insert the social movement's agenda into the government's policy and program. The insertion of the tagline "No Rights No REDD+" was successfully employed to focus REDD+ discourses on Indigenous rights, enabled partly because several AMAN activists were adopting expert subjectivities as members of the REDD+ Taskforce.

\subsubsection{Tensions and Contradictions}

De Freitas, Marston and Bakker (2015) emphasize the need for scholars to probe evolving political agendas that influence the way neoliberal nature projects unravel. REDD+ is shaped and translated by the socio-institutional complexity in which it is embedded (McGregor et al., 2015). REDD+ programs are intertwined with contemporary and historical processes of forest governance creating a messy landscape with a gap between what is intended and what is accomplished. Contradiction comes when the previous governmental tactics and rationalities clash with the new calculated technologies (Li, 2007c; Boelens, Hoogesteger and Baud, 2015; Pieck, 2015). An example of this is the response from the REDD+ Agency officials to the lobbying by a project manager of PT Rimba Raya Conservation, one of the large scale REDD+ private investments in Indonesia covering an area of more 
than 30 thousand hectares. The project manager has several times pitched suggestions for the Agency to buy Rimba Raya's Certified Emissions Reductions (CERs) using the Norwegian money to set an example of the government's seriousness and commitment for REDD+ to work in Indonesia. However, despite the availability of both money and justification to buy the CERs, the REDD+ Agency decided not to do it for the fear of sending the wrong message to the broader civil society movement in Indonesia. A representative of the Agency stated in an interview that,

We don't want to be mistaken to prioritise the need of the REDD+ investor in gaining profit over the need of the forest communities and Indigenous peoples. Although it makes sense for us to buy the CERs to attract more REDD+ investors but we cannot do it now. Not right now...! We still want to focus on empowering communities and a broader vision of good forest governance, because that's how REDD+ is going to be taken seriously by the district governments (Wandi, interview, September 2013).

The statement above shows that, despite the intention for REDD+ to work in Indonesia, the Agency is still reluctant to get involved directly in the purchasing of carbon credits from a large scale REDD+ investment. This disinclination seems to contradict the government's own attempts to mainstream neoliberal rationalities instead more emphasis is being put on REDD+ as an emancipatory forest politics that benefits local and Indigenous communities. The new governmental rationality of governing forest and forest people based on carbon commodification are at a crossroads with other rationalities that are not necessarily prioritizing carbon forestry conservation and offsets. This contradiction creates productive tensions that can be exploited by environmental and Indigenous activists to repurpose REDD+ governmental technologies to serve broader interests of social justice (Anthias and Radcliffe, 2015; de Freitas, 2015; Marston, 2015).

Another example of contradiction that has helped in producing not-quite neoliberal REDD+ projects comes from the overlapping of authorities between the REDD+ Taskforce and the MOF. Political scholars have argued that President Yudhoyono's 
tendency to establish ad-hoc agencies created tensions between the existing institutions with the newly established ones (Luttrell et al., 2012), which was also the case with the REDD+ Taskforce as discussed in Chapter 5. The establishment of the Taskforce can actually add a new overlapping layer in the already messy forest governance in Indonesia. The Taskforce initiated several initiatives that intersected with the MOF's programs and authorities. This resulted in the tensions and rivalries between the Taskforce and the MOF as well as confusion for other forest stakeholders (Astuti and McGregor, 2015).

For the civil society movement in Indonesia, however, this creates a good opportunity for building a stronger alliance with the Taskforce as both parties have a more common interest. For the Taskforce, an alliance with the civil society sector means a strong legitimacy for its existence and authority amidst broader resentments from the majority of the existing government ministries (Astuti and McGregor, 2015). For the activists, the Taskforce provides a new space that offers hopes and flexibility, as it has autonomous financial resources and support from the global community, facilitating the birth of new initiatives that are not tightly tied to the complexity of forest bureaucracy. It doesn't mean, however, that the two parties align neatly, as this alliance is fragile partly due to diverse interests of the civil society, which is far from homogeneous in their views of REDD+ (Mulyani and Jepson, 2013; Brockhaus, Di Gregorio and Mardiah, 2014).

These two examples of tensions and contradictions illustrate how overlapping political processes and agendas have modulated the production and execution of REDD+ governmental technologies that reflect the not-quite neoliberal nature in REDD+.

\subsubsection{Dynamism}

The research has shown that it might be necessary to rethink neoliberalisation of nature projects, such as REDD+, as the stories that emerge are far from simple. It is not a straightforward case of turning forests into commodities to accumulate wealth and profit for the few (Castree, 2011; Milne and Adams, 2012; McElwee et al., 2014). 
The discussion in the core chapters of this thesis showed that even this neoliberal nature project is continuously being contested, (re)shaped, and subverted by social movements. This attempt to continuously repurpose a neoliberal nature project is enabled by the final element that arises out of the three case studies: dynamism (de Freitas, Marston and Bakker, 2015; McGregor, Eilenberg and Coutinho, 2015). Dynamism is enabled by the continuous process of refurbishing the attempt to govern and improve the relation between "men and things" (Foucault, 1991a).

In explaining the nature of governmentality, not as a finished and secure accomplishment, Li (2007c, p. 10) argues that projects will always be contested. Opponents will find deficiencies and "questions that experts exclude, misrecognize, or attempt to contain, do not go away". These conditions will incite experts to propose new projects of improvement. This process is a cycle of attempts to continuously re-arrange human-nature relationships. Sometimes experts will be confronted by their failure in taming their targets of government or by the problems that cannot be contained in the process of rendering technical. Li (2007c, p. 19) further argues that governmental intervention produces contradictions and a perverse effects that "is caused, in part at least, by the overlapping of various governmental programs in historical sequence or, concurrently, one program at cross purpose with another."

Improvement programs, such as REDD+, may inadvertently stimulate a political challenge, "the way they do this, moreover, is situated and contingent" (Li, 2007c, p. 26). De Freitas, Marston and Bakker (2015, p. 243) argue that "dynamism therefore creates the conceptual space amidst so much ambiguity to appreciate the ways in which actors exploit and enlarge political openings (no matter how seemingly inauspicious) that might allow them to strengthen and elaborate upon their continually evolving agendas" (see also Ferguson, 2010).

\subsection{Contribution}

In this thesis, I have made several contributions to knowledge. The thesis represents one of the first attempts to employ governmentality as a theoretical framework in 
analysing REDD+ in Indonesia. I have examined the way a global neoliberal nature project becomes translated into place-based governmental technologies and are subverted, in turn, by the politics of place. I have highlighted the messiness that accompanies attempts to neoliberalise nature. In doing so, I have advanced understandings of neoliberal natures by avoiding simplification around a grand narrative of capital accumulation (Ferguson, 2010; de Freitas, Marston and Bakker, 2015). By conducting empirical analyses I have shown how place based discourses, politics and actor agencies influence how neoliberal projects unfold (Muradian et al., 2010; McElwee et al., 2014).

This thesis has also made an important contribution to advancing the understanding of not-quite neoliberal projects in the context of a non-Latin American country (for Latin American context see for example Anthias and Radcliffe, 2015; Boelens, Hoogesteger and Baud, 2015; de Freitas, 2015; de Freitas, Marston and Bakker, 2015; Marston, 2015; Pieck, 2015). While most studies on post-neoliberalism are located in the context of Latin America, there is a growing interest in finding out the expression of emerging market based environmental governance in other tropical developing countries, such as Indonesia. Hosting more REDD+ projects than anywhere else in the world, Indonesia has proven a fertile ground to explore not quite neoliberal environmental governance (McGregor, Eilenberg and Coutinho, 2015).

Thirdly, this research has made a contribution to the understanding of REDD+ as an emerging governmentality (Tikly, 2003; Fimyar, 2008). By investigating the production of REDD+ governmental technologies, and looking at the tensions that emerged when new governmental technologies encountered old discourses and practices, this thesis has advanced understandings of how governmentalities form (Li, 2007c). Investigating REDD+ in Indonesia as it was designed and implemented provided a unique opportunity to unravel the politics that takes place behind-thescenes in the production of governmental technologies - while they are young and fluid rather than set and old. This captures both continuity and discontinuity of the Indonesian case with neoliberal practices and discourses of the global REDD+ paradigm (McGregor, 2010; McGregor, Eilenberg and Coutinho, 2015; McGregor et 
al., 2015). The understanding of how REDD+ projects are intimately interwoven with other place based discourses and power helps reconceptualize and de-fetishize REDD+ as a top down neoliberal environmental governance. This research has also contributed to the scholarly thinking on hopeful research that attempts to understand the slippages and spaces through which social change is a possibility, instead of focusing on despair that inhibits the excitement conducive to finding and highlighting alternatives and hopes (Gibson-Graham, 2008).

\subsection{Further Research}

Many of the observations recorded in this thesis will benefit from further research. In particular research needs to be done on how full implementation of REDD+, as opposed to the current REDD+ readiness phase, will change the dynamics of REDD+ governmentalities. It will be interesting to examine the extent to whether greater capital investment will influence the implementation and focus of not-quite neoliberal governmental technologies. Similarly research is needed to follow through on the effects of new technologies - such as how will the implementation of standards for participative mapping affect the clarification of Indigenous tenure rights? How will REDD+ impact Indigenous territorialisation and the ensuing intimate exclusion that follows in the years to come?

Further research is needed on private sector influences on environmental governance. This includes the behind the scenes influences touched upon in this thesis but also more broadly how carbon rationalities in the governing of natural resources management in Indonesia will reflect private interests. The latest example is the signing of a pledge by five biggest palm oil companies operating in Indonesia, and whose refining capacities account for $80 \%$ of the global market share, to pursue the vision of developing "sustainable palm oil that is deforestation free, respects human and community rights and improves Indonesia's market competitiveness" (Witoelar, 2015). To the surprise of many actors, the government raised objections to the pledge, calling it a mechanism that "hurts farmers, usurps the government's authority and might constitute a cartel dominated by foreign interests" (Saturi and 
Nugraha, 2015). The government statement could be the starting point for further research that looks into how, post-REDD+ inception, carbon rationalities are adopted by the private sector and what new calculative techniques are going to be produced and implemented by the signatories of the pledge? What impacts it will have on other actors, such as small scale palm oil growers? What particular subjectivities are being engendered?

\subsection{Concluding Remarks}

To conclude, I will come back to the quotation that I cited at the beginning of this chapter. It is risky to claim-and I do not intend to do so-that the findings in this research represent the whole reality of REDD+ in Indonesia. It is, as I mentioned earlier in the Introduction, merely a snapshot of the messy actualities of REDD+ in a country considered "ground zero". This research has been uniquely shaped by its particularity in terms of the timing of the study, the case studies that I chose, the positionality that I embodied, and the collaborators that I worked with. Therefore, the findings have to be read whilst contextualizing and keeping in mind all of these elements. Arguing through the findings of the three case studies that REDD+ in Indonesia is the expression of a not-quite neoliberal nature project do not necessarily erase the possibility that it will later be fully implemented through neoliberal rationalities and technologies. I hope that by conducting this research that I have learned things that can inform my future contributions to scholarly activism, and that perhaps this research will inspire further critical discussion. 


\section{Appendices}

\subsection{Appendix A: List of Indonesia's Government Ministries Related to REDD+}

\begin{tabular}{|c|c|c|}
\hline Abbreviation & $\begin{array}{l}\text { Government } \\
\text { Agency }\end{array}$ & $\begin{array}{l}\text { Roles/Functions/Mandates in relation to } \\
\text { forest, land or REDD+ }\end{array}$ \\
\hline MOF & $\begin{array}{l}\text { Ministry of } \\
\text { Forestry }\end{array}$ & $\begin{array}{l}\text { Ministry of Forestry is a government agency } \\
\text { responsible for overseeing the use and } \\
\text { protection of forestland in Indonesia. MOF } \\
\text { responsibility covers Indonesia's lands that are } \\
\text { classified as forest estate. MOF works based on } \\
\text { the roles and functions defined in the Basic } \\
\text { Forestry Law (BFL). }\end{array}$ \\
\hline MOE & $\begin{array}{l}\text { Ministry of } \\
\text { Environment }\end{array}$ & $\begin{array}{l}\text { Ministry of Environment is a government agency } \\
\text { responsible for coordinating, planning and } \\
\text { monitoring of Indonesia's environment. }\end{array}$ \\
\hline NLA & $\begin{array}{l}\text { National Land } \\
\text { Agency }\end{array}$ & $\begin{array}{l}\text { National Land Agency is a government agency } \\
\text { responsible for managing and issuing certificates } \\
\text { of ownership for lands outside the forest estate. } \\
\text { NLA's mandates are described in the Basic } \\
\text { Agrarian Law (BAL). }\end{array}$ \\
\hline MOA & $\begin{array}{l}\text { Ministry of } \\
\text { Agriculture }\end{array}$ & $\begin{array}{l}\text { Ministry of Agriculture is a ministerial level } \\
\text { government agency which relates to REDD+ } \\
\text { issues through its responsibilities to oversee } \\
\text { plantation sector in Indonesia (palm oil). }\end{array}$ \\
\hline GIA & $\begin{array}{l}\text { Geospatial } \\
\text { Information } \\
\text { Agency }\end{array}$ & $\begin{array}{l}\text { Geospatial Information Agency's relation with } \\
\text { Indonesia's REDD+ is formed through the One } \\
\text { Map Initiative. GIA is the only ministerial level } \\
\text { agency mandated to oversee the management of } \\
\text { Indonesia's spatial information including the task } \\
\text { to produce one common basic map of the } \\
\text { country. }\end{array}$ \\
\hline UKP4 & $\begin{array}{l}\text { President's } \\
\text { Delivery Unit } \\
\text { for } \\
\text { Development } \\
\text { Monitoring } \\
\text { and Oversight }\end{array}$ & $\begin{array}{l}\text { UKP4 is a special body that was formed during } \\
\text { President Yudhoyono's presidency to address } \\
\text { silos among ministries and monitor the } \\
\text { completion of national strategic programs. The } \\
\text { UKP4 was heavily involved in REDD+ through the } \\
\text { appointment of Kuntoro Mangkusubroto, the }\end{array}$ \\
\hline
\end{tabular}




\begin{tabular}{|c|c|c|}
\hline & & $\begin{array}{l}\text { head of UKP4, as the head of the REDD+ } \\
\text { Taskforce. Since then, UKP4 played a key role as } \\
\text { REDD+ proponent in Indonesia. }\end{array}$ \\
\hline $\begin{array}{l}\text { The REDD+ } \\
\text { Taskforce }\end{array}$ & $\begin{array}{l}\text { The REDD+ } \\
\text { Taskforce }\end{array}$ & $\begin{array}{l}\text { The Taskforce is an ad-hoc ministerial level } \\
\text { government agency that was formed to } \\
\text { accelerate the implementation of REDD+ in } \\
\text { Indonesia. Having Kuntoro Mangkusubroto as } \\
\text { the head of both UKP4 and the Taskforce had } \\
\text { deemed very strategic as most of UKP's staffs } \\
\text { also work in the REDD+ Taskforce. }\end{array}$ \\
\hline Bappenas & $\begin{array}{l}\text { National } \\
\text { Development } \\
\text { Planning } \\
\text { Agency }\end{array}$ & $\begin{array}{l}\text { Bappenas is a government level ministry that is } \\
\text { responsinle to develop the road map for national } \\
\text { development planning. }\end{array}$ \\
\hline $\begin{array}{l}\text { The REDD+ } \\
\text { Agency }\end{array}$ & $\begin{array}{l}\text { The REDD+ } \\
\text { Agency }\end{array}$ & $\begin{array}{l}\text { The REDD+ Agency was established in December } \\
2013 \text { to replace the Taskforce. The Agency was } \\
\text { expected to be a permanent agency responsible } \\
\text { for REDD+ implementation in Indonesia. } \\
\text { However, in January 2015, President Jokowi } \\
\text { decided to dissolve the Agency within the newly } \\
\text { formed Ministry of Environment and Forestry. }\end{array}$ \\
\hline MOEF & $\begin{array}{l}\text { Ministry of } \\
\text { Environment } \\
\text { and Forestry }\end{array}$ & $\begin{array}{l}\text { Ministry of Environment and Forestry is the } \\
\text { newly formed government agency under } \\
\text { President Jokowi. The ministry is the result of } \\
\text { merger between four government bodies: the } \\
\text { Ministry of Forestry, the Ministry of } \\
\text { Environment, the REDD+ Agency, and the } \\
\text { National Council on Climate Change. The new } \\
\text { ministry established a new Directorate General } \\
\text { on Climate Change to fill the vacuum left by the } \\
\text { REDD+ Agency and the National Council on } \\
\text { Climate Change. }\end{array}$ \\
\hline
\end{tabular}




\subsection{Appendix B: Human Ethics Approval}

TE WHARE WĀNANGA O TE ŪPOKO O TE IKA A MĀUI

VICTORIA

UNIVERSITY OF WELLINGTON

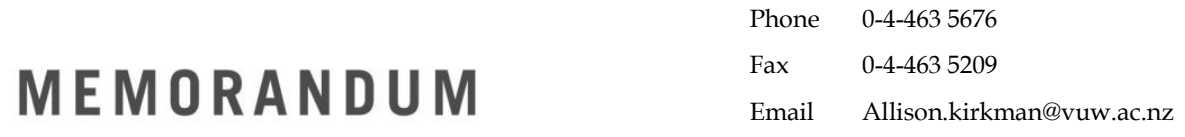

\begin{tabular}{l|l}
\hline TO & Rini Astuti \\
\hline COPY TO & $\begin{array}{l}\text { Andrew McGregor } \\
\text { Sophie Bond }\end{array}$ \\
\hline FROM & Dr Allison Kirkman, Convener, Human Ethics Committee \\
\hline DATE & 7 May 2013 \\
\hline PAGES & 1 \\
\hline
\end{tabular}

SUBJECT

Ethics Approval: 19805

REDD+ Governmentality: governing forest power and politics in Indonesia

Thank you for your application for ethical approval, which has now been considered by the Standing Committee of the Human Ethics Committee.

Your application has been approved from the above date and this approval continues until 30 August 2015. If your data collection is not completed by this date you should apply to the Human Ethics Committee for an extension to this approval.

Best wishes with the research.

Allison Kirkman

Human Ethics Committee 


\subsection{Appendix C: Information and Consent Forms}

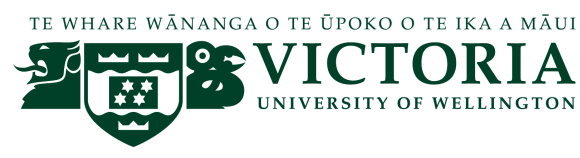

REDD+ Governmentality: Governing forest power and politics in Indonesia Information Sheet for Interview Participants

Thank you for your interest in taking part in this research. Please read this information sheet before deciding whether or not to participate.

This research is being conducted to gain an understanding of the politics and governance issues arising around the Reducing Emissions from Deforestation and Forest Degradation Plus (REDD+) Programme in Indonesia. The research explores how REDD+ is changing forest politics in Indonesia and is being shaped by those same politics. The research is interested in the strategies of organisations to implement the program as well as the ways in which the program is being politicised and contested. While the research is primarily focused on the national scale it also seeks to explore the relationship between national stakeholders and more local actors in a particular case study. The research will explore how forest stakeholders (for instance: Ministry of Forestry, palm oil industries, environmental NGOs and forest dependent communities) engage with REDD+ implementation and governance in Indonesia.

To conduct this research, I wish to interview REDD+ stakeholders in Indonesia. Participants include representatives from: government officials, NGOs, International NGOs, research organizations, donor agencies, related private sector, affected communities, and academics.

\section{Interview Format}

This interview will take approximately $45-60$ minutes of your time and will be audio recorded. It is based on a semi-structured format so the exact nature of the questions have not been determined in advance but will depend on the way that the interview develops. Should the line of questioning progress in a way that makes you uncomfortable you can decline to answer any question(s) at any stage.

\section{Participation}

Your participation is completely voluntary and you can leave the interview at any time and retract any statements made before 28 February 2014 without any disadvantage to yourself. On the consent form, you are given the option of using an organisation's name (you must have the authority or have obtained prior permission to allow the researcher to name your organisation), or a code name to maintain anonymity (for instance, Participant One or a fictional name).

\section{Data Use and Storage}

All the data will be kept confidential and securely stored in a password-protected computer, only my supervisors and I will have access to the raw data. The raw data will be transcribed by a transcriber who has signed a confidentiality agreement. At the end of the project any personal information will be destroyed immediately, except that on which published results rely. These data will be stored securely for a period of five years.

It is intended that this research will form the basis of the researcher's PhD thesis, articles and book publications, and also conference presentations. Direct quotes will be used in the publications and that although every effort will be made to keep your identity confidential, anyone close to the issues may be able to identify you through your comments.

\section{Feedback}

You may receive a final report with the findings if you wish (please indicate on the consent form). You may also receive a copy of any interview transcript. Any request for transcript change will be taken into consideration.

This research has been approved by the Human Ethics Committee at Victoria University of Wellington and is funded by the Royal Society of New Zealand through the Marsden Fund.

If you have any further questions at any time, please contact either Rini Astuti (primary researcher) or Dr Andrew McGregor (supervisor) on the details below.

Researcher: Rini Astuti, rini.astuti@vuw.ac.nz, +64224099200

Supervisor: Dr Andrew McGregor, andrew.mcgregor@vuw.ac.nz,+61298507993 


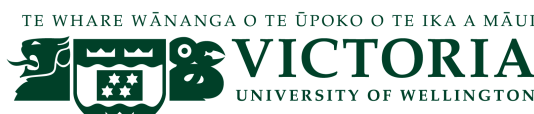

REDD+ Governmentality: Governing forest power and politics in Indonesia Consent Form for Interview Participants

You have been asked to take part in a research study by Rini Astuti from the School of Geography, Environment and Earth Sciences at Victoria University of Wellington (VUW), New Zealand. This study will explore REDD+ implementation and governance in Indonesia. The results of this study will be included in the researcher's doctoral thesis, it is also anticipated that the findings of the study will be written up for publications.

Thank you for taking part in this research.

- I have read and understood the Information Sheet and listened to an explanation about the research.

- I am aware that participation is purely voluntary and I can withdraw at any time, refuse to answer any questions, or retract any statements before 28 Feb 2014 without any disadvantage

- I understand that I can request more information at any time.

- I am aware that I may be quoted in any results or publications, but that my name will not be used. A pseudonym or identifier such as interview 1 or Participant One will be used.

- I understand that that information I give will not be used for any purpose other than those listed below and in the information sheet without my consent. I understand that such information will be treated in accordance with the terms of the Data Protection Act applicable both in New Zealand and Indonesia.

I would like to receive a copy of the transcript of my interview

I would like to receive a final report of the research

$\mathrm{Y} / \mathrm{N}$ (please circle)

I give consent for the researcher to use my organisation name

$Y / N$

My contact details are:

Email:

Address:

$\mathrm{Y} / \mathrm{N}$

Participant's Statement:

I

agree that the research project named above has been explained to me to my satisfaction and I agree to take part in the study. I have read both the notes written above and the Information Sheet about the project, and understand what the research study involves. 


\title{
9.4 Appendix D: Transcriber Confidentiality Agreement
}

\author{
TE WHARE WĀNANGA O TE ŪPOKO O TE IKA A MĀUI

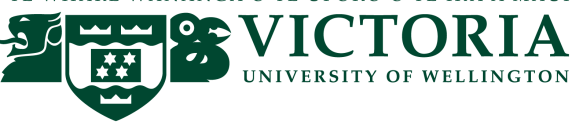 \\ Transcriber Confidentiality Agreement \\ REDD+ Governmentality: Governing forest power and politics in Indonesia
}

This research is being undertaken by Rini Astuti, $\mathrm{PhD}$ candidate in Geography, Victoria University of Wellington. This research is being conducted to gain an understanding of the politics and governance issues arising around the Reducing Emissions from Deforestation and Forest Degradation Plus (REDD+) Programme in Indonesia.

As a transcriber of this research, I understand that I will be hearing recordings of confidential interviews. The information on these recordings has been revealed by interviewees who agreed to participate in this research on the condition that their interviews would remain strictly confidential. I understand that I have a responsibility to honour this confidentially agreement. I agree not to share any information on these recordings, about any party, with anyone except the Researcher of this project. Any violation of this and the terms detailed below would constitute a serious breach of ethical standards and I confirm that I will adhere to the agreement in full.

I, agree to:

1. Keep all the research information shared with me confidential by not discussing or sharing the content of the interviews with anyone other than the Researcher.

2. Keep all research information in any form or format (e.g. audio files, CDs, transcripts) secure while it is in my possession.

3. Return all research information in any form or format (e.g. audio files, CDs, transcripts) to the Researcher when I have completed the transcription tasks.

4. After consulting with the Researcher, erase or destroy all research information in any form or format regarding this research project that is not returnable to the Researcher (e.g. CDs, information stored on my computer hard drive).

Transcriber:

$\overline{\text { (name) }} \overline{\text { (signature) }} \overline{\text { (date) }}$

Researcher:

(name)

(signature)

(date)

This research has been approved by the Human Ethics Committee at Victoria University of Wellington and is funded by the Royal Society of New Zealand through the Marsden Fund.

If you have any further questions at any time, please contact either Rini Astuti (primary researcher) or Dr Andrew McGregor (supervisor) on the details below.

Researcher: Rini Astuti, rini.astuti@vuw.ac.nz, +64224099200

Supervisor: Dr Andrew McGregor, andrew.mcgregor@vuw.ac.nz, +61298507993 


\subsection{Appendix E: JKPP's Participative Mapping Procedures}

Requirements
Output

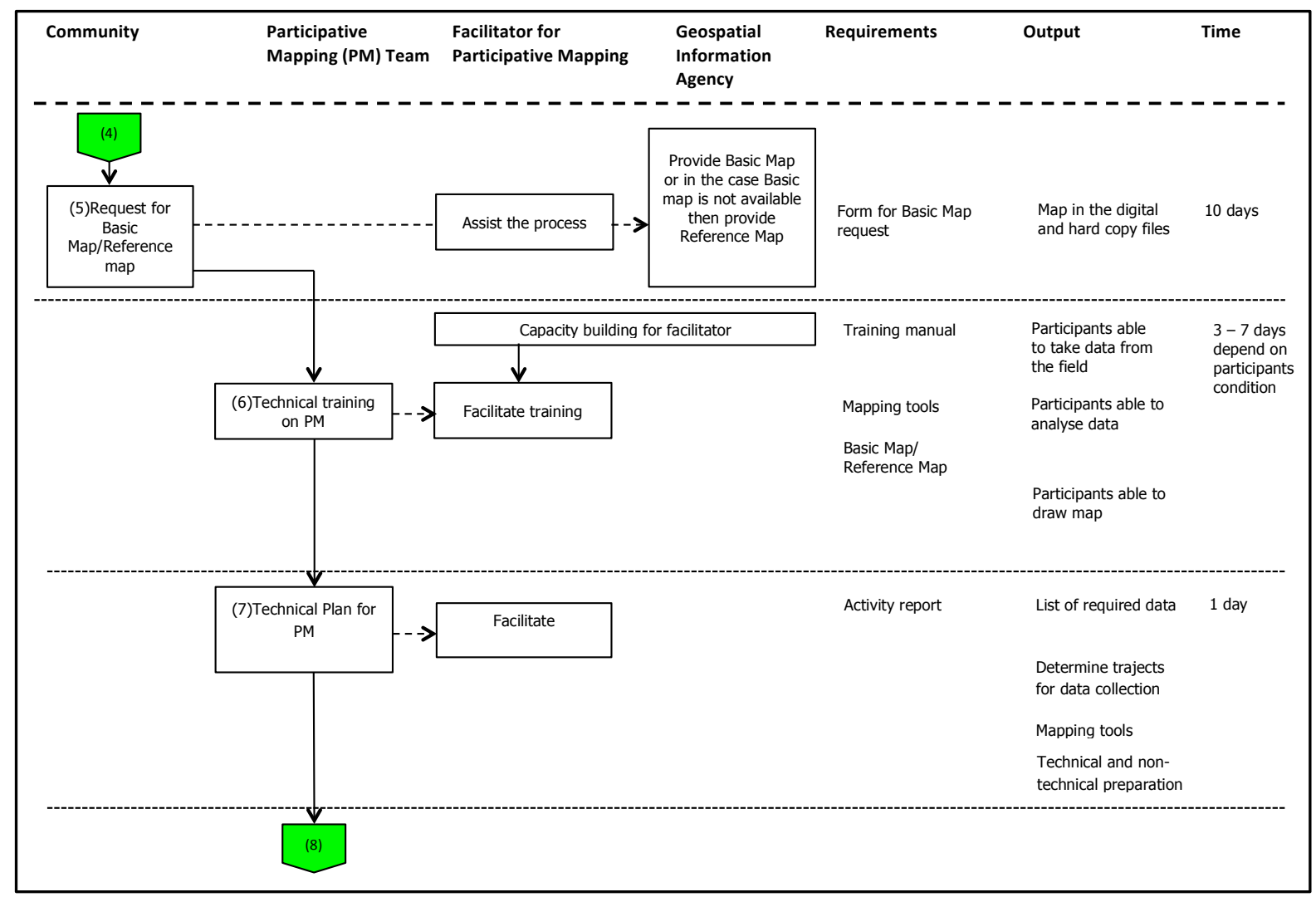




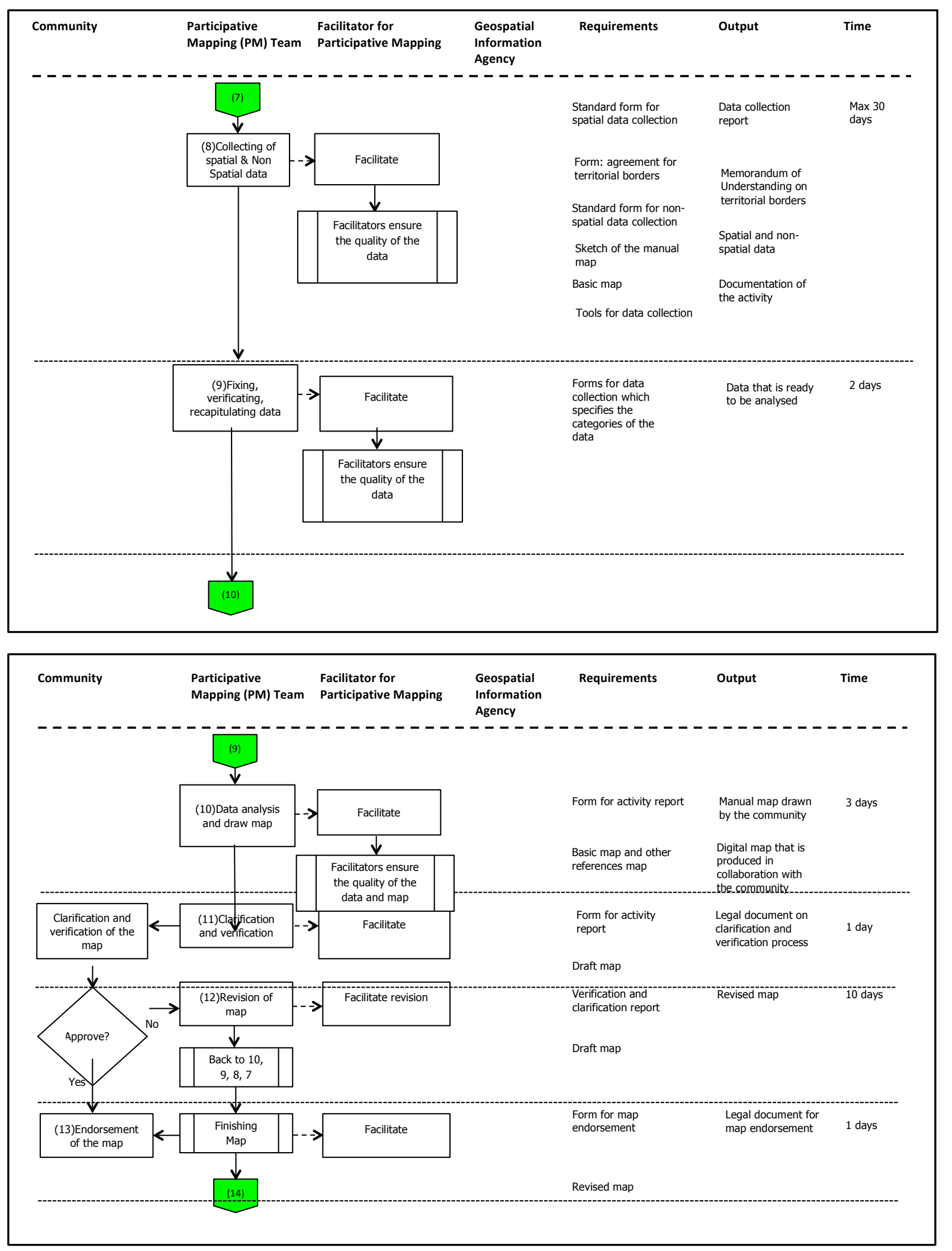




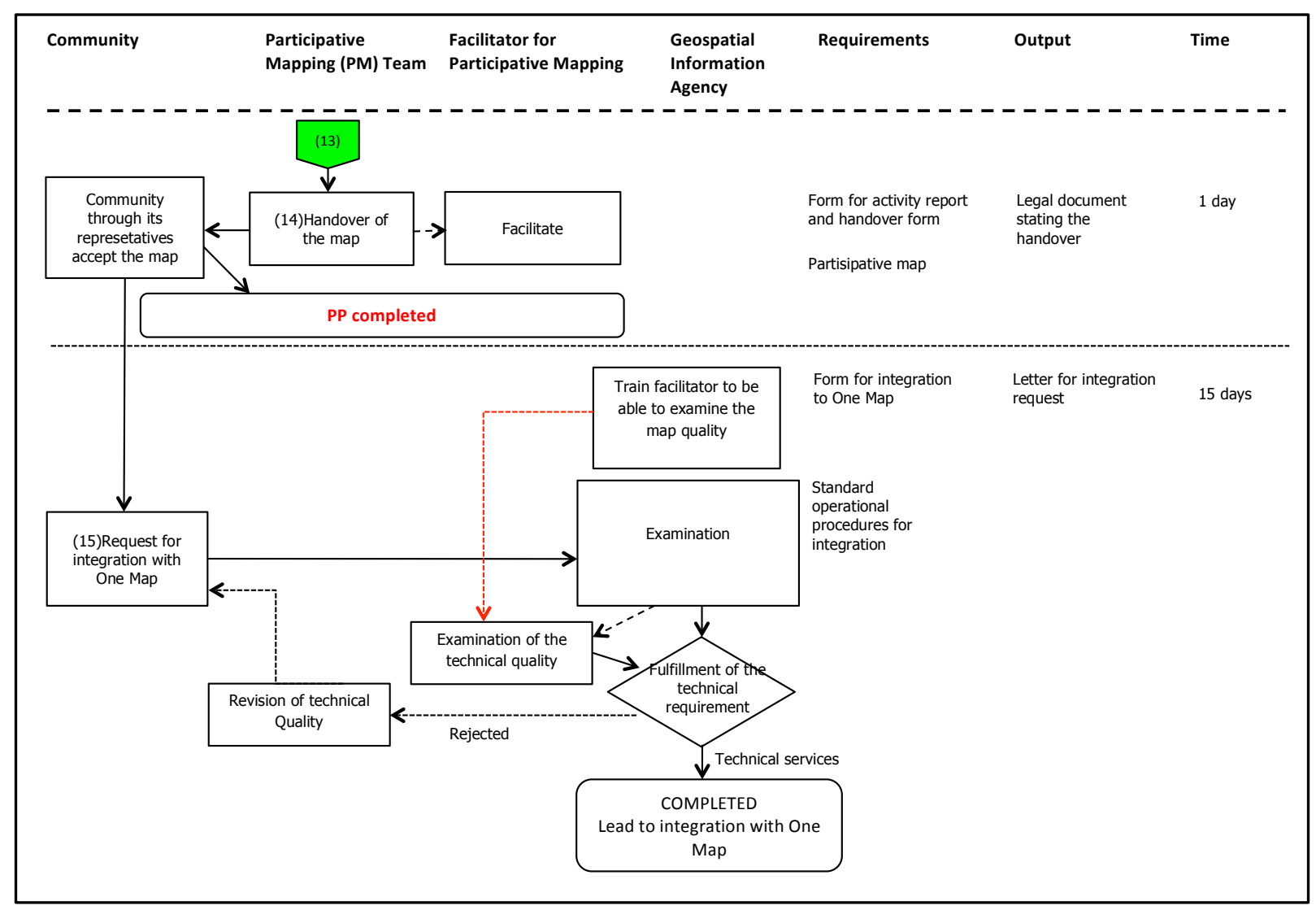




\section{References}

Adi, M. (2013) 'Satgas REDD+ dan Kementerian Kehutanan Berebut Kewenangan Mengelola Program REDD', SIEJ, 21 February.

Aditjondro, G. J. (2003) Pola-pola gerakan lingkungan: refleksi untuk menyelamatkan lingkungan dari ekspansi modal. Jakarta, Indonesia: Pustaka Pelajar.

Afiff, S. and Lowe, C. (2007) 'Claiming Indigenous Community: Political Discourse and Natural Resource Rights in Indonesia', Alternatives: Global, Local, Political, 32(1), pp. 73-97. doi: 10.1177/030437540703200104.

Agrawal, A. (2005) Environmentality: technologies of government and the making of subjects. Durham: Duke University Press.

Agung, P., Galudra, G., Van Noordwijk, M. and Maryani, R. (2014) 'Reform or reversal: the impact of REDD+ readiness on forest governance in Indonesia', Climate Policy, pp. 1-21. doi: 10.1080/14693062.2014.941317.

Agustine, I. (2014) Wapres dan Sembilan K/L Sepakati Program Pengakuan Masyarakat Hukum Adat, Bisnis.com. Available at: http://m.bisnis.com/industri/read/20140901/99/254259/wapres-dan-sembilankl-sepakati-program-pengakuan-masyarakat-hukum-adat (Accessed: 23 October 2014).

Aicher, C. (2014) 'Discourse practices in environmental governance: social and ecological safeguards of REDD', Biodiversity and Conservation, 23(14), pp. 35433560. doi: 10.1007/s10531-014-0812-5.

AMAN (2014) 'Pidato Sekretaris Jenderal AMAN menyambut hari Kebangkitan Masyarakat Adat Nusantara 2014 dan 15 Tahun AMAN'.

Anderson, B. and McFarlane, C. (2011) 'Assemblage and geography', Area, 43(2), pp. 124-127. doi: 10.1111/j.1475-4762.2011.01004.x.

Angelsen, A., Brockhaus, M., Sunderlin, W. D. and Verchot, L. V. (2012) Analysing REDD+: Challenges and choices. Bogor, Indonesia: CIFOR.

Antara News (2011) Pengamat: Rinpres Kehutanan Pesanan Asing. Available at: http://www.antaranews.com/berita/243181/pengamat-rinpres-kehutananpesanan-asing (Accessed: 29 March 2014).

Anthias, P. and Radcliffe, S. A. (2015) 'The ethno-environmental fix and its limits: Indigenous land titling and the production of not-quite-neoliberal natures in Bolivia', Geoforum. doi: 10.1016/j.geoforum.2013.06.007. 
Arsel, M. and Büscher, B. (2012) 'Nature ${ }^{\mathrm{TM}}$ Inc.: Changes and Continuities in Neoliberal Conservation and Market-based Environmental Policy', Development and Change, 43(1), pp. 53-78. doi: 10.1111/j.1467-7660.2012.01752.x.

Ashwin, Anne M. Larson, Amy E. Duchelle, Rodd Myers and Jazmin Gonzales Tovar (2015) 'Multilevel governance challenges in transitioning towards a national approach for REDD+: evidence from 23 subnational REDD+ initiatives', International Journal of the Commons, 9(2), pp. 909-931.

Askins, K. (2009) “'That's just what I do": Placing emotion in academic activism', 2(1), pp. 4-13. doi: 10.1016/j.emospa.2009.03.005.

Asner, G. P. (2009) 'Tropical forest carbon assessment: integrating satellite and airborne mapping approaches', Environmental Research Letters, 4(3), p. 034009. doi: 10.1088/1748-9326/4/3/034009.

Aspinall, E. and Fealy, G. (2003) Local Power \& Politics in Indonesia: Decentralisation $\&$ Democratisation. Singapore: Institute of Southeast Asian Studies.

Aspinall, E., Mietzner, M. and Tomsa, D. (2015) The Yudhoyono Presidency: Indonesia's Decade of Stability and Stagnation. Singapore: Institute of Southeast Asian Studies.

Astuti, R. (2013) Forest moratorium: contesting interests and the road to a just and sustainable policy, The Jakarta Post. Available at: http://www.thejakartapost.com/news/2013/03/04/forest-moratoriumcontesting-interests-and-road-a-just-and-sustainable-policy.html (Accessed: 4 September 2014).

Astuti, R. and McGregor, A. (2015) 'Governing carbon, transforming forest politics: A case study of Indonesia's REDD+ Task Force', Asia Pacific Viewpoint, 56(1), pp. 2136. doi: 10.1111/apv.12087.

Atela, J. O., Minang, P. A., Quinn, C. H. and Duguma, L. A. (2015) 'Implementing REDD+ at the local level: Assessing the key enablers for credible mitigation and sustainable livelihood outcomes', Journal of Environmental Management, 157, pp. 238-249. doi: 10.1016/j.jenvman.2015.04.015.

Atmadja, S., Indriatmoko, Y., Utomo, N. A., Komalasari, M. and Ekaputri, A. D. (2014) Kalimantan Forests and Climate Partnership, Central Kalimantan, Indonesia. Center for International Forestry Research (CIFOR), Bogor, Indonesia. Available at: http://www.cifor.org/library/5277/kalimantan-forests-and-climate-partnershipcentral-kalimantan-indonesia/ (Accessed: 2 August 2015).

Bäckstrand, K. (2004) 'Scientisation vs. Civic Expertise in Environmental Governance: Eco-feminist, Eco-modern and Post-modern Responses', Environmental Politics, 13(4), pp. 695-714. doi: 10.1080/0964401042000274322.

Bäckstrand, K. and Lövbrand, E. (2006) 'Planting Trees to Mitigate Climate Change: Contested Discourses of Ecological Modernization, Green Governmentality and Civic 
Environmentalism', Global Environmental Politics, 6(1), pp. 50-75. doi: 10.1162/glep.2006.6.1.50.

Bakker, K. (2009) 'Neoliberal nature, ecological fixes, and the pitfalls of comparative research', Environment and Planning A, 41(8), pp. 1781 - 1787. doi: 10.1068/a4277.

Bakker, K. (2010) 'The limits of "neoliberal natures": Debating green neoliberalism', Progress in Human Geography, 34(6), pp. 715-735. doi: 10.1177/0309132510376849.

Bakker, K. (2013) 'Neoliberal Versus Postneoliberal Water: Geographies of Privatization and Resistance', Annals of the Association of American Geographers, 103(2), pp. 253-260. doi: 10.1080/00045608.2013.756246.

Bakker, L. (2009) Who Owns the Land?: Looking for law and power in reformasi East Kalimantan. Radboud Universiteit Nijmegen.

Baldwin, A. (2003) 'The Nature of the Boreal Forest Governmentality and ForestNature', Space and Culture, 6(4), pp. 415-428. doi: 10.1177/1206331203253189.

Baldwin, A. (2013) 'Vital ecosystem security: Emergence, circulation, and the biopolitical environmental citizen', Geoforum, 45, pp. 52-61. doi: 10.1016/j.geoforum.2012.01.002.

Barr, C. M. (2006) Decentralization of Forest Administration in Indonesia: Implications for Forest Sustainability, Economic Development, and Community Livelihoods. CIFOR, pp 1 - 15.

Barr, C., Resosudarmo, I. A. P., McCarthy, J. and Dermawan, A. (2006) 'Forest and Decentralization in Indonesia: an Overview', in Decentralization of Forest Administration in Indonesia: Implications for Forest Sustainability, Economic Development and Community Livelihoods. Bogor, Indonesia: CIFOR.

Barry, A. (2001) Political Machines: Governing a Technological Society. London: A\&C Black.

Barry, A., Osborne, T. and Rose, N. S. (1996) Foucault and Political Reason: Liberalism, Neo-Liberalism, and Rationalities of Government. Chicago: University of Chicago Press.

Bear, C. (2013) 'Assembling the sea: materiality, movement and regulatory practices in the Cardigan Bay scallop fishery', Cultural Geographies, 20(1), pp. 21-41. doi: $10.1177 / 1474474012463665$.

Benford, R. D. and Snow, D. A. (2000) 'Framing Processes and Social Movements: An Overview and Assessment', Annual Review of Sociology, 26(1), pp. 611-639. doi: 10.1146/annurev.soc.26.1.611.

Benjaminsen, T. A. and Bryceson, I. (2012) 'Conservation, green/blue grabbing and accumulation by dispossession in Tanzania', Journal of Peasant Studies, 39(2), pp. 335-355. doi: 10.1080/03066150.2012.667405. 
Beymer-Farris, B. A. and Bassett, T. J. (2012) 'The REDD menace: Resurgent protectionism in Tanzania's mangrove forests', Global Environmental Change, 22(2), pp. 332-341. doi: 10.1016/j.gloenvcha.2011.11.006.

Biermann, F. (2007) "Earth system governance" as a crosscutting theme of global change research', Global Environmental Change, 17(3-4), pp. 326-337. doi: 10.1016/j.gloenvcha.2006.11.010.

Biermann, F., Abbott, K., Andresen, S., Bäckstrand, K., Bernstein, S., Betsill, M. M., Bulkeley, H., Cashore, B., Clapp, J., Folke, C., Gupta, A., Gupta, J., Haas, P. M., Jordan, A., Kanie, N., Kluvánková-Oravská, T., Lebel, L., Liverman, D., Meadowcroft, J., Mitchell, R. B., Newell, P., Oberthür, S., Olsson, L., Pattberg, P., Sánchez-Rodríguez, R., Schroeder, H., Underdal, A., Vieira, S. C., Vogel, C., Young, O. R., Brock, A. and Zondervan, R. (2012) 'Transforming governance and institutions for global sustainability: key insights from the Earth System Governance Project', Current Opinion in Environmental Sustainability, 4(1), pp. 51-60. doi: 10.1016/j.cosust.2012.01.014.

Biermann, F., Pattberg, P., Asselt, H. van and Zelli, F. (2009) 'The Fragmentation of Global Governance Architectures: A Framework for Analysis', Global Environmental Politics, 9(4), pp. 14-40.

Bisnis Indonesia (2010) Gapki tolak moratorium pengembangan kebun sawit, www.bumn.go.id. Available

at: http://www.bumn.go.id/ptpn13/berita/663/Gapki.tolak.moratorium.pengembanga n.kebun.sawit (Accessed: 15 February 2015).

Blok, A. (2013) 'Experimenting on Climate Governmentality with Actor Network Theory', in Stripple, J. and Bulkeley, H. (eds) Governing the Climate: New Approaches to Rationality, Power and Politics. Cambridge: Cambridge University Press, pp. 64 81.

Blom, B., Sunderland, T. and Murdiyarso, D. (2010) 'Getting REDD to work locally: lessons learned from integrated conservation and development projects', Environmental Science \& Policy, 13(2), pp. 164-172. doi: 10.1016/j.envsci.2010.01.002.

Blyth, S., Ravilious, C., Purwanto, J., Epple, C., Kapos, V., Barus, H., Afkar, H., Setyawan, A. and Bodin, B. (2012) 'Using spatial information to promote multiple benefits from REDD+ in Indonesia: A compendium of maps for Central Sulawesi Province'. UNREDD.

Boas, H. (2011) ‘No REDD papers volume one’. Carbon Trade Watch.

Boelens, R., Hoogesteger, J. and Baud, M. (2015) 'Water reform governmentality in Ecuador: Neoliberalism, centralization, and the restraining of polycentric authority and community rule-making', Geoforum, 64, pp. 281-291. doi: 10.1016/j.geoforum.2013.07.005.

Boer, H. (2013) 'Governing Ecosystem Carbon', Global Environmental Politics, 13(4), pp. 123-143. 
Bondi, L. (2009) 'Teaching Reflexivity: Undoing or Reinscribing Habits of Gender?', Journal of Geography in Higher Education, 33(3), pp. 327-337. doi: 10.1080/03098260902742417.

Borras, S. M., Hall, R., Scoones, I., White, B. and Wolford, W. (2011) 'Towards a better understanding of global land grabbing: an editorial introduction', The Journal of Peasant Studies, 38(2), pp. 209-216. doi: 10.1080/03066150.2011.559005.

Borras, S. M., Kay, C., Gómez, S. and Wilkinson, J. (2012) 'Land grabbing and global capitalist accumulation: key features in Latin America', Canadian Journal of Development Studies/Revue canadienne d'études du développement, 33(4), pp. 402416. doi: 10.1080/02255189.2012.745394.

Brenner, N., Peck, J. and Theodore, N. (2010a) 'After Neoliberalization?', Globalizations, 7(3), pp. 327-345. doi: 10.1080/14747731003669669.

Brenner, N., Peck, J. and Theodore, N. (2010b) 'Variegated neoliberalization: geographies, modalities, pathways', Global Networks, 10(2), pp. 182-222. doi: 10.1111/j.1471-0374.2009.00277.x.

Brockhaus, M., Di Gregorio, M. and Mardiah, S. (2014) 'Governing the design of national REDD +: An analysis of the power of agency', Forest Policy and Economics, 49, pp. 23-33. doi: 10.1016/j.forpol.2013.07.003.

Brockhaus, M., Obidzinski, K., Dermawan, A., Laumonier, Y. and Luttrell, C. (2012) 'An overview of forest and land allocation policies in Indonesia: Is the current framework sufficient to meet the needs of REDD+?', Forest Policy and Economics, 18, pp. 30-37. doi: 10.1016/j.forpol.2011.09.004.

Brockington, D. and Duffy, R. (2010) 'Capitalism and Conservation: The Production and Reproduction of Biodiversity Conservation', Antipode, 42(3), pp. 469-484. doi: 10.1111/j.1467-8330.2010.00760.x.

Browne, K., Bakshi, L. and Law, A. (2010) in Smith, S., Pain, R., Marston, S., and Jones, J. P. (eds) The SAGE Handbook of Social Geographies. 1 Oliver's Yard, 55 City Road, London EC1Y 1SP United Kingdom: SAGE Publications Ltd, pp. 586 - 605. Available at: http://knowledge.sagepub.com/view/hdbk_socialgeo/SAGE.xml (Accessed: 16 September 2015).

Bulkeley, H. (2000) 'Discourse coalitions and the Australian climate change policy network', Environment and Planning C: Government and Policy, 18(6), pp. 727 - 748. doi: 10.1068/c9905j.

Bulkeley, H. and Newell, P. (2010) Governing Climate Change. London: Routledge.

Bulkeley, H. and Schroeder, H. (2012) 'Beyond state/non-state divides: Global cities and the governing of climate change', European Journal of International Relations, 18(4), pp. 743-766. doi: 10.1177/1354066111413308.

Bulkeley, H. and Stripple, J. (2013) 'Conclusion: Towards a Critical Social Science of Climate Change?', in Stripple, J. and Bulkeley, H. (eds) Governing the Climate: New 
Approaches to Rationality, Power and Politics. Cambridge: Cambridge University Press, pp. $266-282$.

Bulte, E. H., Lipper, L., Stringer, R. and Zilberman, D. (2008) 'Payments for ecosystem services and poverty reduction: concepts, issues, and empirical perspectives', Environment and Development Economics, 13(03), pp. 245-254. doi: 10.1017/S1355770X08004348.

Bumpus, A. G. and Liverman, D. M. (2008) 'Accumulation by Decarbonization and the Governance of Carbon Offsets', Economic Geography, 84(2), pp. 127-155. doi: 10.1111/j.1944-8287.2008.tb00401.x.

Burgess, R., Hansen, M., Olken, B. A., Potapov, P. and Sieber, S. (2011) The Political Economy of Deforestation in the Tropics. Working Paper 17417. National Bureau of Economic Research. Available at: http://www.nber.org/papers/w17417 (Accessed: 2 August 2015).

Büscher, B., Dressler, W. and Fletcher, R. (2014) Nature Inc.: Environmental Conservation in the Neoliberal Age. Tuscon: University of Arizona Press.

Büscher, B. and Fletcher, R. (2015) 'Accumulation by Conservation', New Political Economy, 20(2), pp. 273-298. doi: 10.1080/13563467.2014.923824.

Büscher, B., Sullivan, S., Neves, K., Igoe, J. and Brockington, D. (2012) 'Towards a Synthesized Critique of Neoliberal Biodiversity Conservation', Capitalism Nature Socialism, 23(2), pp. 4-30. doi: 10.1080/10455752.2012.674149.

Butler, J. and Davies, B. (2008) Judith Butler in conversation: analyzing the texts and talk of everyday life. London: Routledge.

Cahill, C., Sultana, F. and Pain, R. (2007) 'Participatory Ethics: Politics, Practices, Institutions', ACME: An International E-Journal for Critical Geographies, 6(3), pp. 304-318.

Caldecott, J., Rizki, D., Rinne, P. and Halonen, M. (2013) 'Indonesia-Norway REDD+ Partnership Second Verivication of Deliverables'. Gaia onsulting Ltd.

Cameron, J. and Gibson, K. (2005) 'Alternative Pathways to Community and Economic Development: The Latrobe Valley Community Partnering Project', Geographical Research, 43(3), pp. 274-285. doi: 10.1111/j.1745-5871.2005.00327.x.

Castree, N. (2008a) 'Neoliberalising nature: processes, effects, and evaluations', Environment and Planning A, 40(1), pp. 153 - 173. doi: 10.1068/a39100.

Castree, N. (2008b) 'Neoliberalising nature: the logics of deregulation and reregulation', Environment and Planning A, 40(1), pp. 131-152. doi: 10.1068/a3999.

Castree, N. (2010a) 'Crisis, Continuity and Change: Neoliberalism, the Left and the Future of Capitalism', Antipode, 41, pp. 185-213. doi: 10.1111/j.14678330.2009.00722.x. 
Castree, N. (2010b) 'Neoliberalism and the Biophysical Environment 1: What "Neoliberalism" is, and What Difference Nature Makes to it', Geography Compass, 4(12), pp. 1725-1733. doi: 10.1111/j.1749-8198.2010.00405.x.

Castree, N. (2010c) 'Neoliberalism and the Biophysical Environment 2: Theorising the Neoliberalisation of Nature', Geography Compass, 4(12), pp. 1734-1746. doi: 10.1111/j.1749-8198.2010.00407.x.

Castree, N. (2010d) 'Neoliberalism and the Biophysical Environment: A Synthesis and Evaluation of the Research', Environment and Society: Advances in Research, 1(1), pp. 5-45. doi: 10.3167/ares.2010.010102.

Castree, N. (2011) 'Neoliberalism and the Biophysical Environment 3: Putting Theory into Practice', Geography Compass, 5(1), pp. 35-49. doi: 10.1111/j.17498198.2010.00406.x.

Castree, N., Chatterton, P., Heynen, N., Larner, W. and Wright, M. W. (2010) 'Introduction: The Point Is To Change It', Antipode, 41, pp. 1-9. doi: 10.1111/j.14678330.2009.00713.x.

Cepek, M. L. (2011) 'Foucault in the forest: Questioning environmentality in Amazonia', American Ethnologist, 38(3), pp. 501-515. doi: 10.1111/j.15481425.2011.01319.x.

Cerbu, G. A., Swallow, B. M. and Thompson, D. Y. (2011) 'Locating REDD: A global survey and analysis of REDD readiness and demonstration activities', Environmental Science \& Policy. (Governing and Implementing REDD+), 14(2), pp. 168-180. doi: 10.1016/j.envsci.2010.09.007.

Cobarrubias, S. and Pickles, J. (2009) 'Spacing movements: Mapping practices, global justice and social activism', in The Spatial Turn: Interdisciplinary Perspectives. Abingdon: Routledge, pp. 36 - 58.

Colfer, C. J. P. (2010) Which Way Forward: 'People, Forests, and Policymaking in Indonesia'. Routledge.

Cooke, B. and Kothari, U. (2001) Participation: the New Tyranny?. New York: Zed Books.

Cook, S. and Smith, K. (2012) 'Introduction: Green Economy and Sustainable Development: Bringing back the "social"', Development, 55(1), pp. 5-9. doi: 10.1057/dev.2011.120.

Corbera, E. (2012) 'Problematizing REDD+ as an experiment in payments for ecosystem services', Current Opinion in Environmental Sustainability, 4(6), pp. 612619. doi: 10.1016/j.cosust.2012.09.010.

Corbera, E. and Schroeder, H. (2011) 'Governing and implementing REDD+', Environmental Science \& Policy, 14(2), pp. 89-99. doi: 10.1016/j.envsci.2010.11.002. 
Corson, C., MacDonald, K. I. and Neimark, B. (2013) 'Grabbing "Green”: Markets, Environmental Governance and the Materialization of Natural Capital', Human Geography, 6(1), pp. 1-15.

Cramb, R. A., Colfer, C. J. P., Dressler, W., Laungaramsri, P., Le, Q. T., Mulyoutami, E., Peluso, N. L. and Wadley, R. L. (2009) 'Swidden Transformations and Rural Livelihoods in Southeast Asia', Human Ecology, 37(3), pp. 323-346. doi: 10.1007/s10745-009-9241-6.

Crang, M. (2003) 'Telling materials', in Pryke, M., Rose, G., and Whatmore, S. (eds) Using Social Theory: Thinking Through Research. London: SAGE Publications, pp. 127 $-145$.

Cruikshank, B. (1999) The Will to Empower: Democratic Citizens and Other Subjects. 1 edition. Ithaca, NY: Cornell University Press.

Curtis, B. (1995) 'Taking the State Back Out: Rose and Miller on Political Power', The British Journal of Sociology, 46(4), pp. 575-589. doi: 10.2307/591572.

Dabu, P. (2011) Greenomics Meragukan Akurasi Peta Indikatif Moratorium Hutan kontan.co.id, KONTAN. Available at: http://nasional.kontan.co.id/news/greenomicsmeragukan-akurasi-peta-indikatif-moratorium-hutan-1 (Accessed: 15 February 2015).

Darier, E. (1999) 'Foucault and the Environment', in Discourses of the environment. Malden, PA: Blackwell, pp. 1 - 33.

Dean, M. (2009) Governmentality: Power and Rule in Modern Society. London: SAGE.

Death, C. (2013) 'The Limits of Climate Governmentality', in Stripple, J. and Bulkeley, H. (eds) Governing the Climate: New Approaches to Rationality, Power and Politics. Cambridge: Cambridge University Press, pp. 100 - 115.

DeFries, R. and Rosenzweig, C. (2010) 'Toward a whole-landscape approach for sustainable land use in the tropics', Proceedings of the National Academy of Sciences, 107(46), pp. 19627-19632. doi: 10.1073/pnas.1011163107.

DeLanda, M. (2006) A New Philosophy of Society: Assemblage Theory and Social Complexity. London: A\&C Black.

Delaney, D. and Leitner, H. (1997) 'The political construction of scale', Political Geography. (Political Geography of Scale), 16(2), pp. 93-97. doi: 10.1016/S09626298(96)00045-5.

Deleuze, G. and Guattari, F. (1987) A Thousand Plateaus: Capitalism and Schizophrenia. Minnesota: University of Minnesota Press.

Demeritt, D. (2001) 'Scientific forest conservation and the statistical picturing of nature's limits in the Progressive-era United States', Environment and Planning D: Society and Space, 19(4), pp. 431 - 459. doi: 10.1068/d294. 
Derickson, K. D. and Routledge, P. (2015) 'Resourcing Scholar-Activism: Collaboration, Transformation, and the Production of Knowledge', Professional Geographer, 67(1). doi: 10.1080/00330124.2014.883958.

Dermawan, A., Petkova, E., Sinaga, A. C., Muhajir, M. and Indriatmoko, Y. (2011) 'Preventing the risks of corruption in REDD+ in Indonesia', Center for International Forestry Research. Available at: http://www.cifor.org/library/3476/preventing-therisks-of-corruption-in-redd-in-indonesia/ (Accessed: 13 February 2015).

Dermawan, A. and Sinaga, A. C. (2015) 'Towards REDD+ integrity: Opportunities and challenges for Indonesia'. Available at: http://www.u4.no/publications/towardsredd-integrity-opportunities-and-challenges-for-indonesia/ (Accessed: 2 August 2015).

Dermawan, Petkova, E., Sinaga, E., Muhajir, M. and Indriatmoko, Y. (2011) 'Risks of Corruption in REDD+ in Indonesia'. Bogor: Cifor.

Descheneau, P. and Paterson, M. (2012) 'Between Desire and Routine: Assembling Environment and Finance in Carbon Markets', in Newell, P., Boykoff, M., and Boyd, E. (eds) The New Carbon Economy: Constitution, Governance and Contestation. First. United Kingdom: John Wiley \& Sons, pp. 65 - 85.

Detik.com (2007) Disoraki 'Komprador', Emil Salim Marah, detiknews. Available at: http://news.detik.com//berita/863889/disoraki-komprador-emil-salim-marah (Accessed: 21 August 2015).

Dewan, A. (2014) New tech, better map on tap to protect Indonesian forests, CIFOR Forests News Blog. Available at: http://blog.cifor.org/22534/new-tech-better-mapon-tap-to-protect-indonesian-forests (Accessed: 23 October 2014).

Dewsbury, J.-D. (2011) 'The Deleuze-Guattarian assemblage: plastic habits', Area, 43(2), pp. 148-153. doi: 10.1111/j.1475-4762.2011.01006.x.

Dillon, M. (1995) 'Sovereignty and Governmentality: From the Problematics of the "New World Order" to the Ethical Problematic of the World Order', Alternatives: Global, Local, Political, 20(3), pp. 323-368.

Dixon, R. and Challies, E. (2015) 'Making REDD+ pay: Shifting rationales and tactics of private finance and the governance of avoided deforestation in Indonesia', Asia Pacific Viewpoint, 56(1), pp. 6-20. doi: 10.1111/apv.12085.

Dove, M. R. (1993) 'Smallholder rubber and swidden agriculture in Borneo: A sustainable adaptation to the ecology and economy of the tropical forest', Economic Botany, 47(2), pp. 136-147. doi: 10.1007/BF02862016.

Dove, M. R. (2006) 'Indigenous People and Environmental Politics', Annual Review of Anthropology, 35(1), pp. 191-208. doi: 10.1146/annurev.anthro.35.081705.123235.

Dove, M. R. and Kammen, D. M. (2001) 'Vernacular Models of Development: An Analysis of Indonesia Under the "New Order"', World Development, 29(4), pp. 619639. doi: 10.1016/S0305-750X(01)00002-X. 
Dressler, W. (2014) 'Green governmentality and swidden decline on Palawan Island', Transactions of the Institute of British Geographers, 39(2), pp. 250-264. doi: 10.1111/tran.12026.

Edwards, P. N. (2010) A Vast Machine: Computer Models, Climate Data, and the Politics of Global Warming. Massachuset: MIT Press.

Eilenberg, M. (2015) 'Shades of green and REDD: Local and global contestations over the value of forest versus plantation development on the Indonesian forest frontier', Asia Pacific Viewpoint, 56(1), pp. 48-61. doi: 10.1111/apv.12084.

Ekuatorial.com (2011) 'Peta indikatif moratorium masukkan hutan sekunder?'. Available at: http://ekuatorial.com/en/forests/peta-indikatif-moratoriummasukkan-hutan-sekunder (Accessed: 15 February 2015).

Engel, S., Pagiola, S. and Wunder, S. (2008) 'Designing payments for environmental services in theory and practice: An overview of the issues', Ecological Economics. (Payments for Environmental Services in Developing and Developed Countries), 65(4), pp. 663-674. doi: 10.1016/j.ecolecon.2008.03.011.

Fairhead, J. and Leach, M. (2003) Science, Society and Power: Environmental Knowledge and Policy in West Africa and the Caribbean. Cambridge University Press.

Fairhead, J., Leach, M. and Scoones, I. (2012) 'Green Grabbing: a new appropriation of nature?', Journal of Peasant Studies, 39(2), pp. 237-261. doi: 10.1080/03066150.2012.671770.

Falzon, M.-A. (2009) Multi-Sited Ethnography: Theory, Praxis and Locality in Contemporary Research. London: Ashgate Publishing, Ltd.

Fandi, Nugroho, A. and Niun, M. A. (2013) 'Melihat Implementasi Inpres Moratorium di Kalimantan Tengah: Antara Harapan dan Kenyataan'. Lingkar Belajar Keadilan Iklim WALHI Kalimantan Tengah.

Farley, J. and Costanza, R. (2010) 'Payments for ecosystem services: From local to global', Ecological Economics. (Special Section - Payments for Ecosystem Services: From Local to Global), 69(11), pp. 2060-2068. doi: 10.1016/j.ecolecon.2010.06.010.

Fay, C. and Sirait, M. (2005) 'Kerangka hukum negara dalam mengatur agraria dan kehutanan Indonesia: mempertanyakan sistem ganda kewenangan atas penguasaan tanah', in Tanah masih di langit: penyelesaian masalah penguasaan tanah dan kekayaan alam di Indonesia yang tak kunjung tuntas di era reformasi. Jakarta, Indonesia: Yayasan Kemala, pp. 713 - 723.

Fay, C. and Sirait, M. (2010) 'Reforming the reformist in Post-Soeharto Indonesia', in Colfer, C. J. P. (ed.) Which Way Forward: 'People, Forests, and Policymaking in Indonesia'. Routledge, pp. $126-143$.

Fay, C., Sirait, M. and Kusworo, A. (2000) 'Getting the boundaries right: Indonesia's urgent need to redefine its forest estate. Souetheast Asia Policy Research Working Paper, No. 25'. World Agroforestry Centre. 
Fearnside, P. M. (1997) 'Transmigration in Indonesia: Lessons from Its Environmental and Social Impacts', Environmental Management, 21(4), pp. 553-570. doi: $10.1007 / \mathrm{s} 002679900049$.

Feindt, P. H. and Oels, A. (2005) 'Does discourse matter? Discourse analysis in environmental policy making', Journal of Environmental Policy \& Planning, 7(3), pp. 161-173. doi: 10.1080/15239080500339638.

Ferguson, J. (2010) 'The Uses of Neoliberalism', Antipode, 41, pp. 166-184. doi: 10.1111/j.1467-8330.2009.00721.x.

Fimyar, O. (2008) 'Educational policy - making in post - communist Ukraine as an example of emerging governmentality: discourse analysis of curriculum choice and assessment policy documents (1999-2003)' , Journal of Education Policy, 23(6), pp. 571-594. doi: 10.1080/02680930802382920.

Fletcher, R. (2010) 'Neoliberal environmentality: Towards a poststructuralist political ecology of the conservation debate', Conservation and Society, 8(3), p. 171. doi: 10.4103/0972-4923.73806.

Fletcher, R. and Breitling, J. (2012) 'Market mechanism or subsidy in disguise? Governing payment for environmental services in Costa Rica', Geoforum, 43(3), pp. 402-411. doi: 10.1016/j.geoforum.2011.11.008.

Forsyth, T. (2009) 'Multilevel, multiactor governance in REDD+: participation, integration and coordination', in Angelsen, A. (ed.) Realising REDD+: national strategy and policy options. Bogor, Indonesia: Center for International Forestry Research, pp. 113-124. Available at: http://www.cifor.org/ (Accessed: 9 February 2014).

Foucault, M. (1979) Discipline and punish: the birth of the prison. NY: Knopf Doubleday Publishing Group.

Foucault, M. (1990) The History of Sexuality, Vol. 1: An Introduction. Reissue edition. Translated by R. Hurley. New York: Vintage.

Foucault, M. (1991a) 'Governmentality', in The Foucault effect: Studies in governmentality. Illinois: University of Chicago Press.

Foucault, M. (1991b) 'Governmentality', in Burchell, G., Gordon, C., and Miller, P. (eds) The Foucault effect: Studies in governmentality. London: Harvester Wheatsheaf, pp. 87-104.

Foucault, M. (1998) The History of Sexuality: The will to knowledge. London: Penguin Books.

Foucault, M. (2001) Power. 1 edition. Edited by J. D. Faubion. Translated by R. Hurley. New York: The New Press. 
Foucault, M. (2003) 'Society Must Be Defended': Lectures at the Collège de France, 1975-1976. Edited by M. Bertani and A. Fontana. Translated by F. Ewald and D. Macey. New York: Picador.

Foucault, M. (2009) Security, Territory, Population: Lectures at the Collège de France 1977--1978. 1 edition. New York: Picador.

Fox, J., Fujita, Y., Ngidang, D., Peluso, N., Potter, L., Sakuntaladewi, N., Sturgeon, J. and Thomas, D. (2009) 'Policies, Political-Economy, and Swidden in Southeast Asia', Human Ecology, 37(3), pp. 305-322. doi: 10.1007/s10745-009-9240-7.

De Freitas, C. (2015) 'Old Chico's new tricks: Neoliberalization and water sector reform in Brazil's São Francisco River Basin', Geoforum, 64, pp. 292-303. doi: 10.1016/j.geoforum.2015.05.012.

De Freitas, C., Marston, A. J. and Bakker, K. (2015) 'Not-quite-neoliberal natures in Latin America: An introduction', Geoforum. doi: 10.1016/j.geoforum.2015.05.021.

fwi.or.id (2013) REDD+ Agency: Step Forward or Panic Move?, FWI. Available at: http://fwi.or.id/publikasi/redd-agency-step-forward-or-panic-move/ (Accessed: 17 November 2015).

Galudra, G., Noordwijk, M. V., Suyanto, Sardi, I. and Pradhan, U. (2010) 'Hotspot of Emissions and Confusion: Land Tenure Insecurity, Contested Policies and Competing Claims in the Central Kalimantan ex Mega Rice Project Area'. World Agroforestry Centre.

Gibbs, H. K., Brown, S., Niles, J. O. and Foley, J. A. (2007) 'Monitoring and estimating tropical forest carbon stocks: making REDD a reality', Environmental Research Letters, 2(4), p. 045023. doi: 10.1088/1748-9326/2/4/045023.

Gibson - Graham, J. K. (1994) “ "Stuffed if I know!" : Reflections on post - modern feminist social research', Gender, Place \& Culture, 1(2), pp. 205-224. doi: 10.1080/09663699408721210.

Gibson-Graham, J. k. (2005) 'Surplus Possibilities: Postdevelopment and Community Economies', Singapore Journal of Tropical Geography, 26(1), pp. 4-26. doi: 10.1111/j.0129-7619.2005.00198.x.

Gibson-Graham, J. K. (2006) 'The' End of Capitalism (as We Knew It): A Feminist Critique of Political Economy; with a New Introduction. University of Minnesota Press.

Gibson-Graham, J. K. (2008) 'Diverse economies: performative practices for 'other worlds", Progress in Human Geography, 32(5), pp. 613-632. doi: 10.1177/0309132508090821.

Goede, M. de and Randalls, S. (2009) 'Precaution, preemption: arts and technologies of the actionable future', Environment and Planning D: Society and Space, 27(5), pp. 859 - 878. doi: 10.1068/d2608. 
Gordon, C. (1991) 'Governmental Rationality: an Introduction', in The Foucault effect: Studies in governmentality. Chicago: University of Chicago Press, pp. 1 - 52.

Government of Indonesia (2010a) Keputusan Presiden Republik Indonesia Nomor 19 Tahun 2010 tentang Satuan Tugas Persiapan Pembentukan Kelembagaan REDD+.

Government of Indonesia (2010b) 'Letter of Intent Between Government of Republic of Indonesia and Government of Kingdom of Norway on the Cooperation on Reducing Emissions from Deforestation and Forest Degradation'.

Government of Indonesia (2012a) ‘MRV National Strategy'. REDD+ Task Force.

Government of Indonesia (2012b) 'REDD+ in Indonesia: A catalyst for change'. The REDD+ Task Force.

Graeber, D. (2004) Fragments of an Anarchist Anthropology. Chicago: Prickly Paradigm Press. Available at: http://www.press.uchicago.edu/ucp/books/book/distributed/F/bo3640795.html (Accessed: 16 September 2015).

Greenpeace (2010) 'Protection Money: Bankrolling deforestation in Indonesia'. Greenpeace International.

Gregory, D., Johnston, R., Pratt, G., Watts, M. and Whatmore, S. (2009) The Dictionary of Human Geography. 5th edn. John Wiley \& Sons.

Gregory, D. and Urry, J. (1985) Social relations and spatial structures. London: Macmillan.

Gupta, A., Lövbrand, E., Turnhout, E. and Vijge, M. J. (2012) 'In pursuit of carbon accountability: the politics of REDD+ measuring, reporting and verification systems', Current Opinion in Environmental Sustainability, 4(6), pp. 726-731. doi: 10.1016/j.cosust.2012.10.004.

Gupta, J. (2012) 'Glocal forest and REDD+ governance: win-win or lose-lose?', Current Opinion in Environmental Sustainability. (4/6 Climate systems), 4(6), pp. 620-627. doi: 10.1016/j.cosust.2012.09.014.

Haalboom, B. (2011) 'Framed Encounters with Conservation and Mining Development: Indigenous Peoples' use of Strategic Framing in Suriname', Social Movement Studies, 10(4), pp. 387-406. doi: 10.1080/14742837.2011.614108.

Hadiz, V. and Robison, R. (2005) 'Neo-liberal Reforms and Illiberal Consolidations: The Indonesian Paradox', The Journal of Development Studies, 41(2), pp. 220-241. doi: 10.1080/0022038042000309223.

Hajer, M. (2005) 'Coalitions, practices, and meanings in environmental politics: from acid rain to BSE', in Howarth, D. and Torfing, J. (eds) Discourse theory in European politics: Identity, policy, and governance. New York: Palgrave Macmillan. 
Hajer, M. A. (1995) The Politics of Environmental Discourse: Ecological Modernization and the Policy Process. NL: Clarendon Press.

Hajer, M. and Versteeg, W. (2005) 'A decade of discourse analysis of environmental politics: Achievements, challenges, perspectives', Journal of Environmental Policy \& Planning, 7(3), pp. 175-184. doi: 10.1080/15239080500339646.

Hall, D., Hirsch, P. and Li, T. M. (2011) Powers of Exclusion: Land Dilemmas in Southeast Asia. Manoa: University of Hawai'i Press.

Handadhari, T. (2015) Bom Waktu Perusakan Hutan - Kompas.com, KOMPAS.com. Available at: http://sains.kompas.com/read/2015/02/24/21223481/Bom.Waktu.Perusakan.Hut an (Accessed: 2 August 2015).

Hannah, M. G. (2000) Governmentality and the Mastery of Territory in NineteenthCentury America. Cambridge University Press.

Harley, J. B. (1989) 'Deconstructing the Map', Cartographica: The International Journal for Geographic Information and Geovisualization, 26(2), pp. 1-20. doi: 10.3138/E635-7827-1757-9T53.

Hart, G. (2004) 'Geography and development: critical ethnographies', Progress in Human Geography, 28(1), pp. 91-100. doi: 10.1191/0309132504ph472pr.

Hartiningsih, M. and Arif, A. (2007) 'Polemik REDD+ Menguat - Pendapat Masyarakat Sipil Terbelah', Kompas.

Harvey, D. (1999) Limits to capital. 2nd edn. London: Verso.

Harvey, D. (2006) 'Neo-Liberalism as Creative Destruction', Geografiska Annaler. Series B, Human Geography, 88(2), pp. 145-158.

Harvey, D. (2009) 'The "New” Imperialism: Accumulation by Dispossession', Socialist Register, 40(40). Available at: http://socialistregister.com/index.php/srv/article/view/5811 (Accessed: 9 March 2013).

Van Heeswijk, L. and Turnhout, E. (2013) 'The discursive structure of FLEGT (Forest Law Enforcement, Governance and Trade): The negotiation and interpretation of legality in the EU and Indonesia', Forest Policy and Economics. (Emerging Forest Regimes), 32, pp. 6-13. doi: 10.1016/j.forpol.2012.10.009.

Hess, D. J. (1995) Science and Technology in a Multicultural World: The Cultural Politics of Facts and Artifacts. New York: Columbia University Press.

Heynen, N. and Robbins, P. (2005) 'The neoliberalization of nature: Governance, privatization, enclosure and valuation', Capitalism Nature Socialism, 16(1), pp. 5-8. doi: 10.1080/1045575052000335339. 
Hodgson, D. L. and Schroeder, R. A. (2002) 'Dilemmas of Counter-Mapping Community Resources in Tanzania', Development and Change, 33(1), pp. 79-100. doi: 10.1111/1467-7660.00241.

Holmes, G. (2014) 'What is a land grab? Exploring green grabs, conservation, and private protected areas in southern Chile', Journal of Peasant Studies, 41(4), pp. 547567. doi: 10.1080/03066150.2014.919266.

Holmgren, S. (2013) 'REDD+ in the making: Orders of knowledge in the climatedeforestation nexus', Environmental Science \& Policy, 33, pp. 369-377. doi: 10.1016/j.envsci.2013.04.007.

Hölzl, R. (2010) 'Historicizing Sustainability: German Scientific Forestry in the Eighteenth and Nineteenth Centuries', Science as Culture, 19(4), pp. 431-460. doi: 10.1080/09505431.2010.519866.

Howell, S. (2014) “No RIGHTS-No REDD”: Some Implications of a Turn Towards CoBenefits', Forum for Development Studies, 41(2), pp. 253-272. doi: 10.1080/08039410.2014.901241.

Howell, S. (2015) 'Politics of appearances: Some reasons why the UN-REDD project in Central Sulawesi failed to unite the various stakeholders', Asia Pacific Viewpoint, 56(1), pp. 37-47. doi: 10.1111/apv.12081.

Howitt, R. and Stevens, S. (2010) 'Cross-Cultural Research: Ethics, Methods and Relationships', in Hay, I. (ed.) Qualitative Research methods in Human Geography. revised 3rd. Toronto: Oxford University Press.

Howson, P. and Kindon, S. (2015) 'Analysing access to the local REDD+ benefits of Sungai Lamandau, Central Kalimantan, Indonesia', Asia Pacific Viewpoint, 56(1), pp. 96-110. doi: 10.1111/apv.12089.

IFCA (2008) 'IFCA consolidation report: Reducing emissions from deforestation and forest degradation'.

Ilcan, S. and Phillips, L. (2010) 'Developmentalities and Calculative Practices: The Millennium Development Goals', Antipode, 42(4), pp. 844-874. doi: 10.1111/j.14678330.2010.00778.x.

Indarto, G. B., Muharjanti, P., Khatarina, J., Pulungan, I., Ivalerina, F., Rahman, J., Prana, M. N., Resosudarmo, I. A. P. and Muharrom, E. (2012) The context of REDD+ in Indonesia: Drivers, agents, and institutions. Bogor: Cifor.

Indonesian REDD+ Task Force (2012) 'REDD+ National Strategy’.

Indrarto, G. B., Murharjanti, P., Khatarina, J., Pulungan, I., Ivalerina, F., Rahman, J., Prana, M. N., Resosudarmo, I. A. P. and Muharrom, E. (2012) 'The context of REDD+ in Indonesia: Drivers, agents and institutions'. Cifor.

IPCC (2007) AR4 synthesis report, Summary for policy makers. New York: Cambridge University Press. 
Ituarte-Lima, C., McDermott, C. L. and Mulyani, M. (2014) 'Assessing equity in national legal frameworks for REDD+: The case of Indonesia', Environmental Science \& Policy, 44, pp. 291-300. doi: 10.1016/j.envsci.2014.04.003.

Jenkins, M., Scherr, S. J. and Inbar, M. (2004) 'Markets for Biodiversity Services: Potential Roles and Challenges', Environment: Science and Policy for Sustainable Development, 46(6), pp. 32-42. doi: 10.1080/00139157.2004.10545160.

Jindal, R., Kerr, J. M. and Carter, S. (2012) 'Reducing Poverty Through Carbon Forestry? Impacts of the N'hambita Community Carbon Project in Mozambique', World Development, 40(10), pp. 2123-2135. doi: 10.1016/j.worlddev.2012.05.003.

JKPP (2014) 'Standard Operating Procedures: Penyelenggaraan Pemetaan Partisipatif dan Pengendalian Kualitas Peta Partisipatif'. Jaringan Kerja Pemetaan Partisipatif.

Johnson, J. T., Cant, G., Howitt, R. and Peters, E. (2007) 'Creating Anti-colonial Geographies: Embracing Indigenous Peoples' Knowledges and Rights', Geographical Research, 45(2), pp. 117-120. doi: 10.1111/j.1745-5871.2007.00441.x.

Jupesta, J., Boer, R., Parayil, G., Harayama, Y., Yarime, M., Oliveira, J. A. P. de and Subramanian, S. M. (2011) 'Managing the transition to sustainability in an emerging economy: Evaluating green growth policies in Indonesia', Environmental Innovation and Societal Transitions, 1(2), pp. 187-191. doi: 10.1016/j.eist.2011.08.001.

Kelly, A. B. (2015) 'The Crumbling Fortress: Territory, Access, and Subjectivity Production in Waza National Park, Northern Cameroon', Antipode, 47(3), pp. 730747. doi: 10.1111/anti.12132.

Kelman, C. C. (2013) 'Governance Lessons from Two Sumatran Integrated Conservation and Development Projects', Conservation and Society, 11(3), p. 247. doi: 10.4103/0972-4923.121028.

Kerr, J. (2002) 'Watershed Development, Environmental Services, and Poverty Alleviation in India', World Development, 30(8), pp. 1387-1400. doi: 10.1016/S0305-750X(02)00042-6.

Kitchin, R. and Tate, N. J. (2000) Conducting research in human geography: theory, methodology and practice. Prentice Hall.

Kompas (2007) 'Emil Salim Merasa Tersinggung', Kompas.

KPK (2012) 'Integrated White Paper: Semiloka Menuju Kawasan Hutan yang Berkepastian Hukum dan Berkeadilan'. Komisi Pemberantasn Korupsi.

KPK (2013) KPK dan 12 Kementerian/Lembaga Tindak Lanjuti Kesepakatan Percepatan Pengukuhan Kawasan Hutan, Komisi Pemberantasan Korupsi. Available at: http://kpk.go.id/id/berita/berita-kpk-kegiatan/1254-kpk-dan-12-kementerianlembaga-tindak-lanjuti-kesepakatan-percepatan-pengukuhan-kawasan-hutan

(Accessed: 2 August 2015). 
Lal, Y. (2012) 'Indonesia and REDD+ moving beyond carbon to sustainable development'. The REDD+ Task Force.

Lang, C. (2013) 'Indonesia's President extends forest moratorium for two more years | REDD-Monitor'. Available at: http://www.reddmonitor.org/2013/05/15/indonesias-president-extends-forest-moratorium-fortwo-more-years/ (Accessed: 15 February 2015).

Leach, M., Rockstrom, J., Raskin, P., Scoones, I., Stirling, A. C., Smith, A., Thompson, J., Millstone, E., Ely, A., Arond, E., Folke, C. and Olsson, P. (2012) 'Transforming Innovation for Sustainability', Ecology and Society, 17(2). doi: 10.5751/ES-04933170211.

Lees, L. (2004) 'Urban geography: discourse analysis and urban research', Progress in Human Geography, 28(1), pp. 101-107. doi: 10.1191/0309132504ph473pr.

Lefebvre, H. (1992) The Production of Space. London: Wiley.

Lemke, T. (2001) “"The birth of bio-politics”: Michel Foucault's lecture at the Collège de France on neo-liberal governmentality', Economy and Society, 30(2), pp. 190-207. doi: 10.1080/03085140120042271.

Lemke, T. (2002) 'Foucault, Governmentality, and Critique', Rethinking Marxism, 14(3), pp. 49-64. doi: 10.1080/089356902101242288.

Lillegraven, A. and Sombolinggi, R. (2014) 'Neither cheap nor quick, but critical', www.redd-monitor.org.

Li, T. M. (1999) 'Compromising Power: Development, Culture, and Rule in Indonesia', Cultural Anthropology, 14(3), pp. 295-322.

Li, T. M. (2000) 'Articulating Indigenous Identity in Indonesia: Resource Politics and the Tribal Slot', Comparative Studies in Society and History, 42(1), pp. 149-179.

Li, T. M. (2001) 'Masyarakat Adat, Difference, and the Limits of Recognition in Indonesia's Forest Zone', Modern Asian Studies, 35(03), pp. 645-676. doi: 10.1017/S0026749X01003067.

Li, T. M. (2005) 'Beyond "The State” and Failed Schemes', American Anthropologist. (New Series), 107(3), pp. 383-394.

Li, T. M. (2007a) 'Governmentality', Anthropologica, 49(2), p. 275.

Li, T. M. (2007b) 'Practices of assemblage and community forest management', Economy and Society, 36(2), pp. 263-293. doi: 10.1080/03085140701254308.

Li, T. M. (2007c) The Will to Improve: Governmentality, Development, and the Practice of Politics. Duke University Press.

Li, T. M. (2007d) The Will to Improve: Governmentality, Development, and the Practice of Politics. Duke University Press. 
Li, T. M. (2007e) The Will to Improve: Governmentality, Development, and the Practice of Politics. Duke University Press.

Li, T. M. (2014a) 'Fixing Non-market Subjects: Governing Land and Population in the Global South', Foucault Studies, 0(18), pp. 34-48.

Li, T. M. (2014b) Land's End: Capitalist Relations on an Indigenous Frontier.

Li, T. M. (2014c) 'What is land? Assembling a resource for global investment', Transactions of the Institute of British Geographers, 39(4), pp. 589-602. doi: 10.1111/tran.12065.

Liverman, D. (2004) 'Who Governs, at What Scale and at What Price? Geography, Environmental Governance, and the Commodification of Nature', Annals of the Association of American Geographers, 94(4), pp. 734-738. doi: 10.1111/j.14678306.2004.00428.x.

Lövbrand, E. and Stripple, J. (2011) 'Making climate change governable: accounting for carbon as sinks, credits and personal budgets', Critical Policy Studies, 5(2), pp. 187-200. doi: 10.1080/19460171.2011.576531.

Lövbrand, E. and Stripple, J. (2013) 'Bringing Governmentality to the Study of Global Climate Governance', in Stripple, J. and Bulkeley, H. (eds) Governing the Climate: New Approaches to Rationality, Power and Politics. Cambridge: Cambridge University Press, pp. 49 - 64.

Lövbrand, E., Stripple, J. and Wiman, B. (2009) 'Earth System governmentality: Reflections on science in the Anthropocene', Global Environmental Change, 19(1), pp. 7-13. doi: 10.1016/j.gloenvcha.2008.10.002.

Lovell, H. (2014) 'Measuring Forest carbon', in Governing the Climate, New Approaches to Rationality, Power and Politics. Cambridge University Press, pp. 198 219.

Lovell, H. and Liverman, D. (2010) 'Understanding Carbon Offset Technologies', New Political Economy, 15(2), pp. 255-273. doi: 10.1080/13563460903548699.

Low, N. (2002) 'Ecosocialisation and environmental planning: a Polanyian approach', Environment and Planning A, 34(1), pp. 43 - 60. doi: 10.1068/a3471.

Lubis, A. M. (2013) Gapki says 'no' to moratorium extension. Available at: http://www.thejakartapost.com/news/2013/04/24/gapki-says-no-moratoriumextension.html\%20 (Accessed: 15 February 2015).

Luke, T. (1999) 'Environmentality as green governmentality', in Darier, E. (ed.) Discourses of the environment. Oxford: Blackwell, pp. $121-151$.

Luttrell, C., Resosudarmo, I. A. P., Muharrom, E., Brockhaus, M. and Seymour, F. (2012) 'The political context of REDD+ in Indonesia: Constituencies for change', Environmental Science \& Policy. doi: 10.1016/j.envsci.2012.10.001. 
MacDonald, L. (2014) A Surprising Indigenous View of REDD+ - Mina Setra and Frances Seymour, Center For Global Development. Available at: http://www.cgdev.org/blog/surprising-indigenous-view-redd-mina-setra-andfrances-seymour (Accessed: 23 October 2014).

Mahanty, S. and McDermott, C. L. (2013) 'How does "Free, Prior and Informed Consent" (FPIC) impact social equity? Lessons from mining and forestry and their implications for REDD+', Land Use Policy, 35, pp. 406-416. doi: 10.1016/j.landusepol.2013.06.014.

Mahanty, S., Suich, H. and Tacconi, L. (2013) 'Access and benefits in payments for environmental services and implications for REDD+: Lessons from seven PES schemes', Land Use Policy, 31, pp. 38-47. doi: 10.1016/j.landusepol.2011.10.009.

Marcus, G. E. (1995) 'Ethnography in/of the World System: The Emergence of MultiSited Ethnography', Annual Review of Anthropology, 24(1), pp. 95-117. doi: 10.1146/annurev.an.24.100195.000523.

Margulis, M. E., McKeon, N. and Borras, S. M. (2013) 'Land Grabbing and Global Governance: Critical Perspectives', Globalizations, 10(1), pp. 1-23. doi: 10.1080/14747731.2013.764151.

Marston, A. J. (2015) 'Autonomy in a post-neoliberal era: Community water governance in Cochabamba, Bolivia', Geoforum, 64, pp. 246-256. doi: 10.1016/j.geoforum.2013.08.013.

Masripatin, N. (2010) 'Indonesia REDD+ strategy and approach for its implementation'. Korea.

Mayaka, T. B. (2002) 'Wildlife Co-Management in the Bénoué National ParkComplex, Cameroon: A Bumpy Road to Institutional Development', World Development, 30(11), pp. 2001-2016. doi: 10.1016/S0305-750X(02)00111-0.

McAfee, K. (1999) 'Selling nature to save it? Biodiversity and green developmentalism', Environment and Planning D: Society and Space, 17(2), pp. 133 154. doi: 10.1068/d170133.

McAfee, K. (2012) 'The Contradictory Logic of Global Ecosystem Services Markets', Development and Change, 43(1), pp. 105-131. doi: 10.1111/j.14677660.2011.01745.x.

Mcafee, K. and Shapiro, E. (2010) 'Payments for Ecosystem Services in Mexico: Nature, Neoliberalism, Social Movements, and the State', Annals of the Association of American Geographers, 100(3), pp. 579-599. doi: 10.1080/00045601003794833.

McCann, E. (2011) 'Veritable inventions: cities, policies and assemblage', Area, 43(2), pp. 143-147. doi: 10.1111/j.1475-4762.2011.01011.x.

McCarthy, J. (2000) 'The Changing Regime: Forest Property and Reformasi in Indonesia', Development and Change, 31(1), pp. 91-129. doi: 10.1111/14677660.00148 . 
McCarthy, J. (2010) 'Processes of inclusion and adverse incorporation: oil palm and agrarian change in Sumatra, Indonesia', The Journal of Peasant Studies, 37(4), pp. 821-850. doi: 10.1080/03066150.2010.512460.

McCarthy, J. and Prudham, S. (2004) 'Neoliberal nature and the nature of neoliberalism', Geoforum, 35(3), pp. 275-283. doi: 10.1016/j.geoforum.2003.07.003.

McCarthy, J., Vel, J. A. C. and Afiff, S. (2012) 'Trajectories of land acquisition and enclosure: development schemes, virtual land grabs, and green acquisitions in Indonesia's Outer Islands', Journal of Peasant Studies, 39(2), pp. 521-549. doi: 10.1080/03066150.2012.671768.

McDermott, C. L., Coad, L., Helfgott, A. and Schroeder, H. (2012) 'Operationalizing social safeguards in REDD+: actors, interests and ideas', Environmental Science \& Policy, 21, pp. 63-72. doi: 10.1016/j.envsci.2012.02.007.

McElwee, P. D. (2012) 'Payments for environmental services as neoliberal marketbased forest conservation in Vietnam: Panacea or problem?', Geoforum, 43(3), pp. 412-426. doi: 10.1016/j.geoforum.2011.04.010.

McElwee, P., Nghiem, T., Le, H., Vu, H. and Tran, N. (2014) 'Payments for environmental services and contested neoliberalisation in developing countries: A case study from Vietnam', Journal of Rural Studies, 36, pp. 423-440. doi: 10.1016/j.jrurstud.2014.08.003.

McGregor, A. (2010) 'Green and REDD? Towards a political ecology of deforestation in Aceh, Indonesia', 3(2), pp. 21 - 34.

McGregor, A. (2015) 'Policy: REDD+ in Asia Pacific', Nature Climate Change, 5(7), pp. 623-624. doi: 10.1038/nclimate2692.

McGregor, A., Challies, E., Howson, P., Astuti, R., Dixon, R., Haalboom, B., Gavin, M., Tacconi, L. and Afiff, S. (2015) 'Beyond carbon, more than forest? REDD+ governmentality in Indonesia', Environment and Planning A, 47(1), pp. $138-155$. doi: $10.1068 / a 140054 p$.

McGregor, A., Eilenberg, M. and Coutinho, J. B. (2015) 'From global policy to local politics: The social dynamics of REDD+ in Asia Pacific', Asia Pacific Viewpoint, 56(1), pp. 1-5. doi: 10.1111/apv.12091.

McGregor, A., Weaver, S., Challies, E., Howson, P., Astuti, R. and Haalboom, B. (2014a) 'Practical critique: Bridging the gap between critical and practice-oriented REDD+ research communities', Asia Pacific Viewpoint, 55(3), pp. 277-291. doi: 10.1111/apv.12064.

McGregor, A., Weaver, S., Challies, E., Howson, P., Astuti, R. and Haalboom, B. (2014b) 'Practical critique: Bridging the gap between critical and practice-oriented REDD+ research communities', Asia Pacific Viewpoint, 55(3), pp. 277-291. doi: 10.1111/apv.12064. 
Mckee, K. (2009) 'Post-Foucauldian governmentality: What does it offer critical social policy analysis?', Critical Social Policy, 29(3), pp. 465-486. doi: 10.1177/0261018309105180.

McWilliam, A. (2006) 'Historical Reflections on Customary Land Rights in Indonesia', The Asia Pacific Journal of Anthropology, 7(1), pp. 45-64. doi: 10.1080/14442210600551859.

Medan Bisnis Daily.com (2011) Industri Sawit Protes Moratorium Hutan, Harian Medan Bisnis. Available at: http://www.medanbisnisdaily.com/news/read/2011/05/23/34475/industrisawit-protes-moratorium-hutan/ (Accessed: 15 February 2015).

Meijaard, E. (2015) 'Commentary: The Final Blow for Indonesia's Forests?', The Jakarta Globe. Available at: http://thejakartaglobe.beritasatu.com/opinion/commentary-final-blow-indonesiasforests/ (Accessed: 31 March 2015).

Merry, S. E. (2001) 'Spatial Governmentality and the New Urban Social Order: Controlling Gender Violence Through Law', American Anthropologist. (New Series), 103(1), pp. 16-29.

Methmann, C. and Rothe, D. (2012) 'Politics for the day after tomorrow: The logic of apocalypse in global climate politics', Security Dialogue, 43(4), pp. 323-344. doi: $10.1177 / 0967010612450746$.

Miller, P. and Rose, N. (1990) 'Governing economic life', Economy and Society, 19(1), pp. 1-31. doi: 10.1080/03085149000000001.

Milne, S. and Adams, B. (2012) 'Market Masquerades: Uncovering the Politics of Community-level Payments for Environmental Services in Cambodia', Development and Change, 43(1), pp. 133-158. doi: 10.1111/j.1467-7660.2011.01748.x.

Minang, P. A., Noordwijk, M. V., Duguma, L. A., Alemagi, D., Do, T. H., Bernard, F., Agung, P., Robiglio, V., Catacutan, D., Suyanto, S., Armas, A., Aguad, C. S., Feudjio, M., Galudra, G., Maryani, R., White, D., Widayati, A., Kahurani, E., Namirembe, S. and Leimona, B. (2014) 'REDD+ Readiness progress across countries: time for reconsideration', Climate Policy, 14(6), pp. 685-708. doi: 10.1080/14693062.2014.905822.

Minnemeyer, S., Laestadius, L. and Potapov, P. (2009) New Hope for Restoring Forest Landscapes. Available at: http://www.wri.org/blog/2009/12/new-hope-restoringforest-landscapes (Accessed: 15 February 2015).

Moeliono, M. and Limberg, G. (2012) The Decentralization of Forest Governance: Politics, Economics and the Fight for Control of Forests in Indonesian Borneo. Routledge.

Mulyani, M. and Jepson, P. (2013) 'REDD+ and Forest Governance in Indonesia: A Multistakeholder Study of Perceived Challenges and Opportunities', The Journal of 
Environment \& Development, p. 1070496513494203. doi: $10.1177 / 1070496513494203$.

Mundy, B. E. (1996) The Mapping of New Spain: Indigenous Cartography and The Maps of Relaciones Geograficas. Chicago and London: University of Chicago Press.

Muradian, R., Corbera, E., Pascual, U., Kosoy, N. and May, P. H. (2010) 'Reconciling theory and practice: An alternative conceptual framework for understanding payments for environmental services', Ecological Economics. (Special Section Payments for Environmental Services: Reconciling Theory and Practice), 69(6), pp. 1202-1208. doi: 10.1016/j.ecolecon.2009.11.006.

Murdiyarso, D., Dewi, S., Lawrence, D. and Seymour, F. (2011) Indonesia's forest moratorium: a stepping stone to better forest governance?. Bogor: Cifor.

Nababan, A. (2013) 'Kebijakan umum menuju pengakuan dan perlindungan masyarakat adat dan wilayah adatnya di Indonesia'. Seminar Nasional Penyempurnaan UU PA Sebagai Peraturan Pokok Agraria, Universitas Brawijaya, Malang.

Nader, L. (1972) 'Up the anthropologist: Perspectives gained from studying up', in Dell, H. (ed.) Reinventing Anthropology. New York: Pantheon Books, pp. 284 - 311.

Nepstad, D., Boyd, W., Stickler, C. M., Bezerra, T. and Azevedo, A. A. (2013) 'Responding to climate change and the global land crisis: REDD+, market transformation and low-emissions rural development', Phil. Trans. R. Soc. B, 368(1619), p. 20120167. doi: 10.1098/rstb.2012.0167.

Nepstad, D., Irawan, S., Bezerra, T., Boyd, W., Stickler, C., Shimada, J., Carvalho, O., MacIntyre, K., Dohong, A., Alencar, A., Azevedo, A., Tepper, D. and Lowery, S. (2013) 'More food, more forests, fewer emissions, better livelihoods: linking REDD+, sustainable supply chains and domestic policy in Brazil, Indonesia and Colombia', Carbon Management, 4(6), pp. 639-658. doi: 10.4155/cmt.13.65.

Nurrochmat, D. R., Dharmawan, A. H., Obidzinski, K., Dermawan, A. and Erbaugh, J. T. (2014) 'Contesting national and international forest regimes: Case of timber legality certification for community forests in Central Java, Indonesia', Forest Policy and Economics. doi: 10.1016/j.forpol.2014.09.008.

O'Connor, C. M. (2004) 'Effects of Central Decisions on Local Livelihoods in Indonesia: Potential Synergies Between the Programs of Transmigration and Industrial Forest Conversion', Population and Environment, 25(4), pp. 319-333. doi: 10.1023/B:POEN.0000036483.48822.2f.

Oels, A. (2005) 'Rendering climate change governable: From biopower to advanced liberal government?', Journal of Environmental Policy \& Planning, 7(3), pp. 185-207. doi: 10.1080/15239080500339661.

O'Hara, P. A. (2009) 'Political economy of climate change, ecological destruction and uneven development', Ecological Economics. (Special Section: Analyzing the global 
human appropriation of net primary production - processes, trajectories, implications), 69(2), pp. 223-234. doi: 10.1016/j.ecolecon.2009.09.015.

O'Neill, S. J. and Smith, N. (2014) 'Climate change and visual imagery', Wiley Interdisciplinary Reviews: Climate Change, 5(1), pp. 73-87. doi: 10.1002/wcc.249.

Van Oosterzee, P., Blignaut, J. and Bradshaw, C. J. A. (2012) 'iREDD hedges against avoided deforestation's unholy trinity of leakage, permanence and additionality', Conservation Letters, 5(4), pp. 266-273. doi: 10.1111/j.1755-263X.2012.00237.x.

Osborne, T. M. (2011) 'Carbon forestry and agrarian change: access and land control in a Mexican rainforest', Journal of Peasant Studies, 38(4), pp. 859-883. doi: 10.1080/03066150.2011.611281.

Pagiola, S., Arcenas, A. and Platais, G. (2005) 'Can Payments for Environmental Services Help Reduce Poverty? An Exploration of the Issues and the Evidence to Date from Latin America', World Development. (Institutional arrangements for rural poverty reduction and resource conservation), 33(2), pp. 237-253. doi: 10.1016/j.worlddev.2004.07.011.

Pain, R. and Kindon, S. (2007) 'Guest EditorialParticipatory geographies', Environment and Planning A, 39(12), pp. 2807 - 2812. doi: 10.1068/a39347.

Panelli, R. (2004) Social Geographies: From Difference to Action. SAGE.

Paterson, M. and Stripple, J. (2010) 'My Space: governing individuals' carbon emissions', Environment and Planning D: Society and Space, 28(2), pp. 341 - 362. doi: 10.1068/d4109.

Pat O'Malley, L. W. and Clifford, S. (1997) 'Gogernmentality, criticism, policics', Economy and Society, 26(4), pp. 501-217. doi: 10.1080/03085149700000026.

Pearse, R. (2013) 'Back to the land? Legitimation, carbon offsets and Australia's emissions trading scheme', Global Change, Peace \& Security, 25(1), pp. 43-60. doi: 10.1080/14781158.2013.758098.

Peck, J. (2010) Constructions of Neoliberal Reason. Oxford: OUP Oxford.

Peck, J. and Theodore, N. (2007) 'Variegated capitalism', Progress in Human Geography, 31(6), pp. 731-772. doi: 10.1177/0309132507083505.

Peck, J. and Theodore, N. (2012) 'Follow the policy: a distended case approach', Environment and Planning A, 44(1), pp. 21 - 30. doi: 10.1068/a44179.

Peck, J. and Tickell, A. (2007) 'Conceptualizing Neoliberalism , Thinking Tatcherism', in Leitner, H., Peck, J., and Sheppard, E. S. (eds) Contesting Neoliberalism: Urban Frontiers. Guilford Press.

Peluso, N. L. (1992) 'The Political Ecology of Extraction and Extractive Reserves in East Kalimantan, Indonesia', Development and Change, 23(4), pp. 49-74. doi: 10.1111/j.1467-7660.1992.tb00469.x. 
Peluso, N. L. (1995) 'Whose Woods Are These? Counter-Mapping Forest Territories in Kalimantan, Indonesia', Antipode, 27(4), pp. 383-406. doi: 10.1111/j.14678330.1995.tb00286.x.

Peluso, N. L. and Vandergeest, P. (2001) 'Genealogies of the Political Forest and Customary Rights in Indonesia, Malaysia, and Thailand', The Journal of Asian Studies, 60(3), pp. 761-812. doi: 10.2307/2700109.

Permatasari, A. P. (2011) 'Analisis Wacana Moratorium Hutan di dalam Media'. HUMA. Available

at: https://www.academia.edu/6097745/Analisis_Wacana_Moratorium_Hutan_di_dala m_Media (Accessed: 15 February 2015).

Phelps, J., Friess, D. A. and Webb, E. L. (2012) 'Win-win REDD+ approaches belie carbon-biodiversity trade-offs', Biological Conservation. (REDD+ and conservation), 154, pp. 53-60. doi: 10.1016/j.biocon.2011.12.031.

Pieck, S. K. (2015) "'To be led differently": Neoliberalism, road construction, and NGO counter-conducts in Peru', Geoforum, 64, pp. 304-313. doi: 10.1016/j.geoforum.2013.06.011.

Pistorius, T. (2012) 'From RED to REDD+: the evolution of a forest-based mitigation approach for developing countries', Current Opinion in Environmental Sustainability. (4/6 Climate systems), 4(6), pp. 638-645. doi: 10.1016/j.cosust.2012.07.002.

Polanyi, K. (1944) The great transformation: The political and economic origins of our time. Beacon Press.

Poppe, J. (2012) 'Conservation's Ambiguities: Rangers on the Periphery of the W Park, Burkina Faso', Conservation and Society, 10(4), p. 330. doi: 10.4103/09724923.105538.

Pramono, A., H. (2013) Ngekar Utatn Raat Kite: A look into cartographic encounters in counter-mapping exercises in wesr kalimantan, Indonesia. University of Hawai.

Pratt, K. (2012) 'Rethinking community: Conservation, practice, and emotion', Emotion, Space and Society. (Practising Emotional Geographies), 5(3), pp. 177-185. doi: 10.1016/j.emospa.2011.08.003.

Purba, C. P., Nanggara, S. G., Ratriyono, M., Apriani, I., Rosalina, L., Sari, N. A. and Meridian, A. H. (2014) Potret Keadaan Hutan Indonesia Periode 2009 - 2013. Bogor, Indonesia: Forest Watch Indonesia.

Rabinow, P. (1984) 'Introduction', in The Foucault reader. New York: Pantheon Books.

Rachman, N. F. (2013) 'Undoing categorical inequality: customary communities, agrarian conflicts, and struggle for inclusive citizenship in Indonesia'.

Reinhold, S. (1994) Local Conflict and Ideological Struggle: 'Positive Image' and Section 28. Sussex. 
Resosudarmo, B. P. (2005) The Politics and Economics of Indonesia's Natural Resources. Institute of Southeast Asian Studies.

Resosudarmo, I. A. P. (2004) 'Closer to people and trees: Will decentralisation work for the people and the forests of Indonesia?', The European Journal of Development Research, 16(1), pp. 110-132. doi: 10.1080/09578810410001688761.

Rhee, S. (2006) Brokering Authority: Translating knowledge, policy and practice in forestry institutions in Indonesia. Yale.

Rice, J. L. (2010) 'Climate, Carbon, and Territory: Greenhouse Gas Mitigation in Seattle, Washington', Annals of the Association of American Geographers, 100(4), pp. 929-937. doi: 10.1080/00045608.2010.502434.

Rimba Makmur Utama (2015) 'Project Description: Katingan Peatland Restoration and Conservation Project’. PT. Rimba Makmur Utama.

Robbins, P. (2011) Political Ecology: A Critical Introduction. NY: John Wiley \& Sons.

Robertson-Snape, F. (1999) 'Corruption, collusion and nepotism in Indonesia', Third World Quarterly, 20(3), pp. 589-602. doi: 10.1080/01436599913703.

Robins, S. (2002) 'At the limits of spatial governmentality: A message from the tip of Africa', Third World Quarterly, 23(4), pp. 665-689. doi: 10.1080/0143659022000005328.

Roewiastuti, M. R. (2013) Panduan atas putusan Mahkamah Konstitusi Nomor 35/PUU-X/2012: Hutan Adat bukan lagi Hutan Negara. AMAN, AIPP, Sajogyo Institute, Rainforest Foundation Noruega, IWGIA, Tanah Air Beta.

Rose, G. (1997) 'Situating knowledges: positionality, reflexivities and other tactics', Progress in Human Geography, 21(3), pp. 305-320. doi: 10.1191/030913297673302122.

Rose, G. (1999) 'Performing space', in Massey, D., Allen, J., and Sarre, P. (eds) Human Geography Today. Cambridge, UK: Polity Press, pp. 247-259.

Rose, N. (1999a) Governing the soul: the shaping of the private self. Free Association Books.

Rose, N. (1999b) Powers of Freedom: Reframing Political Thought. Cambridge University Press.

Rose, N. and Miller, P. (1992) 'Political Power beyond the State: Problematics of Government', The British Journal of Sociology, 43(2), pp. 173-205. doi: $10.2307 / 591464$.

Rose, N., O'Malley, P. and Valverde, M. (2006) 'Governmentality', Annual Review of Law and Social Science, 2(1), pp. 83-104. doi: 10.1146/annurev.lawsocsci.2.081805.105900. 
Ross, M. L. (1996) The political economy of boom and bust logging in Indonesia, the Philippines, and East malaysia 1950 - 1994. Princeton.

Ross, M. L. (2001) Timber Booms and Institutional Breakdown in Southeast Asia. Cambridge: Cambridge University Press.

Roth, R. (2009) 'The challenges of mapping complex indigenous spatiality: from abstract space to dwelling space', Cultural Geographies, 16(2), pp. 207-227. doi: $10.1177 / 1474474008101517$.

Routledge, P. and Derickson, K. D. (2015) 'Situated solidarities and the practice of scholar-activism', Environment and Planning D: Society and Space, 33(3), pp. 391407. doi: $10.1177 / 0263775815594308$.

Rutherford, S. (2007) 'Green governmentality: insights and opportunities in the study of nature's rule', Progress in Human Geography, 31(3), pp. 291-307. doi: 10.1177/0309132507077080.

Rutherford, S. (2008) Manufacturing the Wild: Nature, Power, and Green Governmentality. York University.

Rutland, T. and Aylett, A. (2008) 'The work of policy: actor networks, governmentality, and local action on climate change in Portland, Oregon', Environment and Planning D: Society and Space, 26(4), pp. 627-646. doi: $10.1068 / \mathrm{d} 6907$.

Safitri, M. (2014) ‘One Land Administration'. Epistema Institute.

Safitri, M. (2015) 'Mencari Perusak Hutan', Kompas.

Safitri, M., Muhshi, M. A., Muhajir, M., Shohibuddin, M., Arizona, Y., Sirait, M., Nagara, G., Andiko, Moniaga, S., Berliani, H., Widawati, E., Mary, S. R., Galudra, G., Santosa, A. and Santoso, H. (2011) 'Menuju Kepastian dan Keadilan Tenurial: Pandangan kelompok masyarakat sipil Indonesia tentang prinsip, prasyarat dan langkah mereformasi kebijakan penguasaan tanah dan kawasan hutan di Indonesia'. Kelompok masyarakat sipil untuk reformasi tenurial.

Sahide, M. A. K. and Giessen, L. (2015) 'The fragmented land use administration in Indonesia - Analysing bureaucratic responsibilities influencing tropical rainforest transformation systems', Land Use Policy, 43, pp. 96-110. doi: 10.1016/j.landusepol.2014.11.005.

Saich, A., Dapice, D., Masoud, T., Perkins, D., Pincus, J., Rosengard, J., Vallely, T., Wilkinson, B. and Williams, J. (2010) From Reformasi to Institutional Transformation: A Strategic Assessment of Indonesia's Prospects for Growth, Equity and Democratic Governance. Ash Center for Democratic Governance and Innovation.

Saloh, Y. and Butler, R. (2011) Dengan Moratorium Indonesia menuju pertumbuhan ekonmi rendah karbon, indonesia.mongabay.com. Available at: http://indonesia.mongabay.com/news/2011/id0527-op-ed_tempo_indonesia.html. 
Samadhi, N. (2012) ‘One Map Movement'. Jakarta, Indonesia, December.

Samadhi, N. (2014) 'Satu Informasi Perizinan: Menuju integrasi perizinan lintas sektor dan daerah untuk pelaksanaan pembangunan yang lebih akuntabel'. Rapat Pembekalan Nasional Tata Kelola Pemerintahan, Jakarta, Indonesia.

Sanchez, L. (2003) 'Sex and Space in the Global City', in Globalization Under Construction: Governmentality, Law, and Identity. University of Minnesota Press.

Satgas REDD+ (2012) 'Laporan Pelaksanaan Tugas Satuan Tugas Persiapan Pembentukan Kelembagaan REDD+'.

Satgas REDD+ (2013a) 'Laporan PelaksanaanTugas Satuan Tugas Persiapan pembentukan Kelembagaan REDD+'.

Satgas REDD+ (2013b) Peran Masyarakat Adat dalam Penanggulangan Dampak Perubahan Iklim, www.reddplus.goid. Available at: http://www.reddplus.go.id/berita/dari-media/339-peran-masyarakat-adat-dalampenanggulangan-dampak-perubahan-iklim.

Satgas REDD+ (2013c) 'Prinsip Kriteria dan Indikator Safeguards REDD+ Indonesia PRISAI: Versi 3.1'. Satgas REDD+.

Saturi, S. (2013) 'AMAN Targetkan Pemetaan 40 Juta Hektar Hutan Adat Selesai 2020', Mongabay.co.id.

Saturi, S. (2014) BIG Siapkan Aplikasi Partisipatif, Bisakah Menjawab Soal Wilayah Adat?, www.mongabay.co.id. Available at: http://www.mongabay.co.id/2014/08/26/big-siapkan-aplikasi-peta-partisipatifbisakah-menjawab-soal-wilayah-adat/.

Saturi, S. and Nugraha, I. (2015) Indonesian officials resist movement to end deforestation for palm oil, www.mongabay.com. Available at: http://news.mongabay.com/2015/09/indonesian-officials-resist-movement-toend-deforestation-for-palm-oil/ (Accessed: 20 November 2015).

Sayer, J., Sunderland, T., Ghazoul, J., Pfund, J.-L., Sheil, D., Meijaard, E., Venter, M., Boedhihartono, A. K., Day, M., Garcia, C., Oosten, C. van and Buck, L. E. (2013) 'Ten principles for a landscape approach to reconciling agriculture, conservation, and other competing land uses', Proceedings of the National Academy of Sciences, 110(21), pp. 8349-8356. doi: 10.1073/pnas.1210595110.

Scheyvens, R. (2014) Development Fieldwork: A Practical Guide. SAGE.

Scott, J. C. (1998) Seeing Like a State: How Certain Schemes to Improve the Human Condition Have Failed. Yale University Press.

Shore, C. and Wright, S. (1997) 'Policy: A new field of anthropology', in Shore, C. and Wright, S. (eds) Anthropology of Policy. London: Routledge, pp. 1 - 39.

Sikor, T. (2013) The Justices and Injustices of Ecosystem Services. Routledge. 
Simamora, A. P. (2010) Business interests blamed for forest moratorium delay, www.thejakartapost.com. Available at: http://www.thejakartapost.com/news/2011/01/12/business-interests-blamedforest-moratorium-delay.html (Accessed: 14 February 2015).

Siscawati, M. (2012) Social Movements and Scientific Forestry: Examining the Community Forestry Movement in Indonesia. University of Washington.

Sitompul, A. F., Linkie, M., Gunaryadi, D., Purastuti, E. and Budiman, A. (2011) 'Ecosystem Restoration Concessions: A New Strategy for Conserving Elephant Habitat in Sumatra?', Gajah, (34), pp. 26-31.

Situmorang, A. W., Nababan, A., Kartodihardjo, H., Khatarina, J., Santosa, M. A., Safitri, M., Soeprihanto, P., Effendi, S. and Sunaryo (2013) Participatory Governance Assessment: The 2012 Indonesia Forest, Land, and REDD+ Governance Index. Jakarta, Indonesia: UNDP Indonesia.

Skoglund, A. (2014) 'Homo Clima: the overdeveloped resilience facilitator', Resilience, 2(3), pp. 151-167. doi: 10.1080/21693293.2014.948325.

Sloan, S. (2014) 'Indonesia's moratorium on new forest licenses: An update', Land Use Policy, 38, pp. 37-40. doi: 10.1016/j.landusepol.2013.10.018.

Soehartono, T. and Mardiastuti, A. (2002) 'Cites Implementation in Indonesia'. Nagao Natural Environment Foundation.

Soja, E. W. (1985) 'The spatiality of social life: towards a transformative retheorisation', in Social relations and spatial structures. London: Macmillan, pp. 90122.

Spiegel, S. J. (2012) 'Governance Institutions, Resource Rights Regimes, and the Informal Mining Sector: Regulatory Complexities in Indonesia', World Development, 40(1), pp. 189-205. doi: 10.1016/j.worlddev.2011.05.015.

Spiteri, A. and Nepal, S. K. (2008) 'Distributing conservation incentives in the buffer zone of Chitwan National Park, Nepal', Environmental Conservation, 35(1), pp. 7686. doi: $10.1017 / \mathrm{S} 0376892908004451$.

Stephan, B. (2012) 'Bringing discourse to the market: the commodification of avoided deforestation', Environmental Politics, 21(4), pp. 621-639. doi: 10.1080/09644016.2012.688357.

Stephan, B. and Paterson, M. (2012) 'The politics of carbon markets: an introduction', Environmental Politics, 21(4), pp. 545-562. doi: 10.1080/09644016.2012.688353.

Stratford, H. (2002) 'Micro-strategies of resistance', Resources for Feminist Research, 29(3/4), pp. 223-232.

Streck, C. (2011) 'Ensuring New Finance and Real Emission Reduction: A Critical Review of the Additionality Concept', Carbon \& Climate Law Review, 2011, p. 158. 
Stripple, J. and Bulkeley, H. (2013a) Governing the Climate: New Approaches to Rationality, Power and Politics. Cambridge University Press.

Stripple, J. and Bulkeley, H. (2013b) 'Introduction: On Governmentality and Climate Change', in Stripple, J. and Bulkeley, H. (eds) Governing the Climate: New Approaches to Rationality, Power and Politics. Cambridge University Press, pp. $24-46$.

Stroshane, T. (1997) 'The second contradiction of capitalism and Karl Polanyi's the great transformation', Capitalism Nature Socialism, 8(3), pp. 93-116. doi: 10.1080/10455759709358751.

Sunderlin, W. D., Larson, A. M., Duchelle, A. E., Resosudarmo, I. A. P., Huynh, T. B., Awono, A. and Dokken, T. (2014) 'How are REDD+ Proponents Addressing Tenure Problems? Evidence from Brazil, Cameroon, Tanzania, Indonesia, and Vietnam', World Development, 55, pp. 37-52. doi: 10.1016/j.worlddev.2013.01.013.

Surya, M. T. (2011) Presidential order vs. forest conversion moratorium. Available at: http://www.thejakartapost.com/news/2011/06/20/presidential-order-vs-forestconversion-moratorium.html (Accessed: 14 February 2015).

Tahilramani, Y. (2013) Mapping Indonesia's future: integrating indigenous claims to land, CIFOR Forests News Blog. Available at: http://blog.cifor.org/13716/mappingindonesias-future-integrating-indigenous-claims-to-land (Accessed: 15 February 2015).

Taylor, M. (2014) "Being useful" after the Ivory Tower: combining research and activism with the Brixton Pound', Area, 46(3), pp. 305-312. doi: 10.1111/area.12117.

Thapa Karki, S. (2013) 'Do protected areas and conservation incentives contribute to sustainable livelihoods? A case study of Bardia National Park, Nepal', Journal of Environmental Management, 128, pp. 988-999. doi: 10.1016/j.jenvman.2013.06.054.

The Autonomous Geographies Collective (2010) 'Beyond Scholar Activism: Making Strategic Interventions Inside and Outside the Neoliberal University', ACME: An International E-Journal for Critical Geographies, 9(2), pp. 245-275.

The Jakarta Post (2014) 'REDD+ Agency hopes for committed new government'.

Thompson, M. C., Baruah, M. and Carr, E. R. (2011) 'Seeing REDD+ as a project of environmental governance', Environmental Science \& Policy, 14(2), pp. 100-110. doi: 10.1016/j.envsci.2010.11.006.

Thorburn, C. (2002) 'Regime Change-Prospects for Community-Based Resource Management in Post-New Order Indonesia', Society \& Natural Resources, 15(7), pp. 617-628. doi: 10.1080/08941920290069227.

Thrift, N. J. (2007) Non-representational Theory: Space, Politics, Affect. Routledge. 
Tikly, L. (2003) 'Governmentality and the study of education policy in South Africa', Journal of Education Policy, 18(2), pp. 161-174. doi: 10.1080/0268093022000043074.

Tsing, A. L. (2005) Friction: An Ethnography of Global Connection. Princeton: Princeton University Press.

UKP4 and Satgas REDD+ (2013) 'Laporan Pemantauan Instruksi Presiden No. 10/2011: Hasil Capain dan Tindak Lanjut'. Kelompok Kerja Monitoring Moratorium Satuan Tugas REDD+.

unep.org (2015) UNEP - Green Economy Initiative - Home. Available at: http://www.unep.org/greeneconomy/ (Accessed: 22 August 2015).

UNFCCC (2008) 'Report of the Conference of the Parties on its thirteenth session'.

UNFCCC (2011) Decision 1/CP.16 The Cancun Agreements: Outcome of the work of the Ad Hoc Working Group on Long-term Cooperative Action under the Convention.

un-redd.org (2015) UN-REDD Programme - About REDD+, www.un-redd.org. Available at: http://www.un-redd.org/aboutredd (Accessed: 21 August 2015).

Vandergeest, P. and Peluso, N. L. (2006) 'Empires of Forestry: Professional Forestry and State Power in Southeast Asia, Part 1', Environment and History, 12(1), pp. 3164.

Vayda, A. P., Colfer, C. J. P. and Brotokusumo, M. (1985) 'Interactions between people and forests in East Kalimantan', in McNeely, J. A. and Pitt, D. C. (eds) Culture and Conservation: The Human Dimension in Environmental Planning. IUCN.

Victor, P. A. and Jackson, Ti. (2012) 'A Commentary on UNEP's Green Economy Scenarios', Ecological Economics, 77, pp. 11-15. doi: 10.1016/j.ecolecon.2012.02.028.

Vignola, R., Locatelli, B., Martinez, C. and Imbach, P. (2009) 'Ecosystem-based adaptation to climate change: what role for policy-makers, society and scientists?', Mitigation and Adaptation Strategies for Global Change, 14(8), pp. 691-696. doi: 10.1007/s11027-009-9193-6.

Wainwright, J. and Bryan, J. (2009) 'Cartography, territory, property: postcolonial reflections on indigenous counter-mapping in Nicaragua and Belize', Cultural Geographies, 16(2), pp. 153-178. doi: 10.1177/1474474008101515.

Walters, W. (2012) Governmentality: Critical Encounters. Routledge.

watchindonesia.org (2008) World market, climate change and the hypocrisy of the North, www.watchindonesia.org. Available at: http://www.watchindonesia.org/Torry.htm (Accessed: 21 August 2015).

Welch, D. (2007) 'A buyer's guide to offsets', Ethical Consumer, 106. 
Wells, M. (1999) Investing in Biodiversity: A Review of Indonesia's Integrated Conservation and Development Projects. World Bank Publications.

Wells, P., Franklin, N., Gunarso, P., Paoli, G., Mafira, T., Kusumo, D. R. and Clanchy, B. (2012) 'Indonesian Constitutional Court Ruling Number 45/PUU-IX/2011 in relation to Forest Lands: Implications for Forest, Development and REDD+'. Daemeter Consulting, Tropenbos International Indonesia and Makarim \& Taira S.

Wertz-Kanounnikoff, S. and Angelsen, A. (2009) 'Global and national REDD+ architecture: Linking institutions and actions', in Angelsen, A. (ed.) Realising REDD+: national strategy and policy options. Bogor, Indonesia: CIFOR, pp. 13 - 24.

Weyland, K. (2003) 'Neopopulism and Neoliberalism in Latin America: How Much Affinity?', Third World Quarterly, 24(6), pp. 1095-1115.

Whatmore, S. (2003) 'Generating Materials', in Using Social Theory: Thinking Through Research. London: SAGE Publications, pp. 89 - 104.

While, A., Jonas, A. E. G. and Gibbs, D. (2010) 'From sustainable development to carbon control: eco-state restructuring and the politics of urban and regional development', Transactions of the Institute of British Geographers, 35(1), pp. 76-93. doi: 10.1111/j.1475-5661.2009.00362.x.

Widhiarto, H. and Gunawan, A. (2014) Komnas HAM holds inquiry to settle land disputes. Available at: http://www.thejakartapost.com/news/2014/09/22/komnasham-holds-inquiry-settle-land-disputes.html (Accessed: 2 August 2015).

Winkel, G. (2012) 'Foucault in the forests-A review of the use of "Foucauldian" concepts in forest policy analysis', Forest Policy and Economics, 16, pp. 81-92. doi: 10.1016/j.forpol.2010.11.009.

Witoelar, W. (2013) 'Dialog antara Wimar Witoelar dan Kuntoro Mangkusubroto tentang REDD+'. TVRI.

Witoelar, W. (2015) Turnaround in palm oil industry?, www.thejakartapost.com. Available at: http://www.thejakartapost.com/news/2015/10/24/turnaroundpalm-oil-industry.html (Accessed: 20 November 2015).

Wright, G. (2011) 'Indigenous People and Customary land Ownership under Domestic Redd Frameworks: A Case Study of Indonesia', Law, Environment and Development Journal, 7, p. 117.

Wunder, S. (2001) 'Poverty Alleviation and Tropical Forests-What Scope for Synergies?', World Development, 29(11), pp. 1817-1833. doi: 10.1016/S0305750X(01)00070-5.

www.v-c-s.org (2015) What is a VCU? / Verified Carbon Standard. Available at: http://www.v-c-s.org/how-it-works/what-vcu (Accessed: 5 November 2015). 
Xiang, B. (2013) 'Multi-scalar ethnography: An approach for critical engagement with migration and social change', Ethnography, p. 1466138113491669. doi: $10.1177 / 1466138113491669$.

Yates, J. S. and Bakker, K. (2014) 'Debating the "post-neoliberal turn" in Latin America', Progress in Human Geography, 38(1), pp. 62-90. doi: 10.1177/0309132513500372.

Zwick, S. (2014) Indonesia Vows: We Will Be Ready For Results-Based REDD Payments By End of 2016, Ecosystem Marketplace. 
